\title{
Annual Report to Congress
}

on

Federal Government Energy Management and Conservation Programs

\section{Eiscal Year 1994}

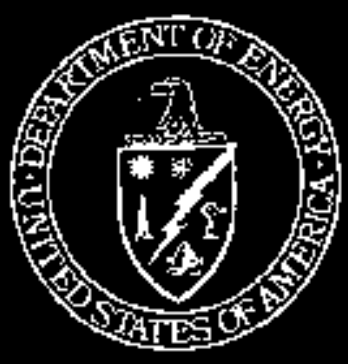

October 6,1995

\section{U.S. Department of Energy}

Assistant Sucretary. Fnergy Efficiency and Renewable Energy

Office of Federal Energy Managernent Programs 


\section{Annual Report to Congress}

\section{on \\ Federal Government Energy Management and Conservation Programs}

\section{Fiscal Year 1994}

\section{DISCIAAMER}

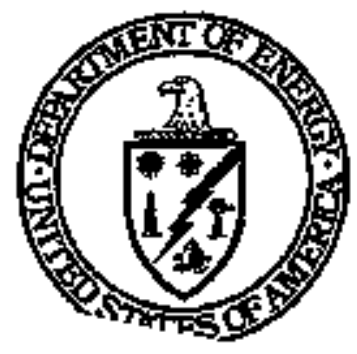

This report wax prepared as to aceount af wosk sponsoced by an agency of the Upited States Gowernmere, Netther the United Sieves Goverament noc any soency thereor, nor any af tacir employes, moke any wartanty, express or implied, or usoumes any lesal liability or respansibility for the accutacy, completoness, or usefintiess of any information, apparatus, moduct, or process dieclowed, or roprewents that is use would not intitinge privately owaed rights. Referance hercipt to any specific commercial product, process, or servica by trade name, trademark, manulacturer, or stherwise does not necessarily eonstitute or imply its endorsemert, recommondetion, or faworing by the Uniled Slates Gowernmene of any agency thereor. The viows and opintons of asthors expressed herein do gok necessarlly slate or reflect those of the Unilod Scutes Govemment os any agency thereof.

October 6, 1995

\section{U.S. Department of Energy}

Assistant Secretary, Energy Efficiency and Renewable Energy Office of Federal Energy Management Programs Washington, DC 20585 



\section{TABLE OF CONTENTS}

I. OVERVIEW OF FEDERAL ENERGY MANAGEMENT ACTIVITIES 6

A. Overview of Federal Energy Management Policy and

Legislative Mandates . . . . . . . . . . . . . . . . . . 6

B. Overall Federal Energy Consumption and Costs $\ldots \ldots \ldots \ldots \ldots 10$

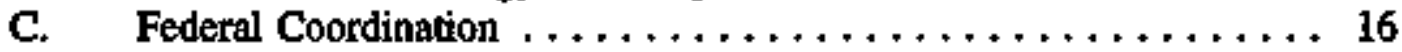

D. Personnel and Energy Awareness Activities $\ldots \ldots \ldots \ldots \ldots, 17$

E. Funding for Energy Efficiency in Buildings and Facilities $\ldots \ldots 24$

- Federal Energy Efficiency Fund $\ldots \ldots \ldots \ldots \ldots \ldots \ldots, 26$

- Energy Savings Performance Contracts ............ 28

- Demand Side Management (DSM) Program Participation ..... 31

F. Life-Cycle Costing (LCC) $\ldots \ldots \ldots \ldots \ldots \ldots \ldots \ldots \ldots, 32$

G. Procurement Policy $\ldots \ldots \ldots \ldots \ldots \ldots \ldots \ldots \ldots \ldots \ldots, 32$

H. Public Education Programs $\ldots \ldots \ldots \ldots \ldots \ldots \ldots \ldots \ldots \ldots, 34$

I. ENERGY MANAGEMENT IN BUILDINGS AND FACILTTIES . . . . 37

A. Energy Consumption and Costs for Buildings and Facilities .... 37

B. Progress Toward the Mandated Goals for Buildings and Facilities . , 44

C. Federal Building Energy Peformance Standards ..........47

III. ENERGY INTENSIVE OPERATIONS IN FEDERAL FACILITIES .. 49

A. Energy Consomption and Costs for Energy Intensive Operations . . 49

B. Legislative Background and Progress Toward Goals

for Industrial Facilities $\ldots \ldots \ldots \ldots \ldots \ldots \ldots \ldots \ldots \ldots$ si

IV. ENERGY MANAGEMENT IN VEAICLES AND EQUIPMENT $\ldots \ldots 54$

A Energy Consumption and Costs for Vehicles and Equipment .... 54

B. Progress Toward the Reduction Goals for Gasoline and

Diesel Consumption $\ldots \ldots \ldots \ldots \ldots \ldots \ldots \ldots \ldots \ldots \ldots \ldots, 59$

C. Alternative Fuel Vehicles $\ldots \ldots \ldots \ldots \ldots \ldots \ldots \ldots \ldots, 60$

D. The Administrative Fleet $\ldots \ldots \ldots \ldots \ldots \ldots \ldots \ldots \ldots, 62$

v. FEDERAL AGENCY ENERGY MANAGEMENT ACTIVITIES . . . 63

1. Department of Agriculture $\ldots \ldots \ldots \ldots \ldots \ldots \ldots \ldots \ldots 6, \ldots \ldots \ldots$

2. Department of Commerce $\ldots \ldots \ldots \ldots \ldots \ldots \ldots \ldots \ldots, 65$

3. Department of Defense $\ldots \ldots \ldots \ldots \ldots \ldots \ldots \ldots \ldots \ldots, 67$

4. Department of Energy ................... 71

5. Department of Health and Human Services $\ldots \ldots \ldots \ldots \ldots 73$

6. Department of Housing and Urban Development . . . . . . . 75

7. Department of the Interior $\ldots \ldots \ldots \ldots \ldots \ldots \ldots \ldots \ldots \ldots 77$

8. Department of Justice $\ldots \ldots \ldots \ldots \ldots \ldots \ldots \ldots \ldots \ldots \ldots$

9. Department of Labor $\ldots \ldots \ldots \ldots \ldots \ldots \ldots \ldots \ldots \ldots \ldots . \ldots 1$

10. Department of State $\ldots \ldots \ldots \ldots \ldots \ldots \ldots \ldots \ldots \ldots \ldots, 83$

11. Department of Transportation $\ldots \ldots \ldots \ldots \ldots \ldots \ldots \ldots \ldots, 85$ 
12. Department of the Treasury $\ldots \ldots \ldots \ldots \ldots \ldots \ldots \ldots \ldots, 87$

13. Department of Veterans Affairs $\ldots \ldots \ldots \ldots \ldots \ldots \ldots \ldots, 89$

14. Environmental Protection Agency $\ldots \ldots \ldots \ldots \ldots, \ldots \ldots, 91$

15. Federal Emergency Management Agency . ............ 93

16. Federal Energy Regulatory Commission $\ldots \ldots \ldots \ldots \ldots \ldots, 95$

17. General Services Administration $\ldots \ldots \ldots \ldots \ldots \ldots \ldots \ldots, 97$

18. National Aeronautics and Space Administration $\ldots \ldots \ldots \ldots \ldots 99$

19. Nuclear Regulatory Commission $\ldots \ldots \ldots \ldots \ldots \ldots \ldots \ldots \ldots, 101$

20. Panama Canal Commission $\ldots \ldots \ldots \ldots \ldots \ldots \ldots \ldots \ldots$

21. Railroad Retirement Board $\ldots \ldots \ldots \ldots \ldots \ldots \ldots \ldots \ldots \ldots . \ldots \ldots$

22. Tennessee Valley Authority $\ldots \ldots \ldots \ldots \ldots \ldots \ldots \ldots \ldots, 107$

23. United States Postal Service . . . . . . . . . . . . . . . . . 109

\section{TABLES}

Table 1 Total Net Energy Consumption By Federal Agencies . . . . . . . 12

Table 2 Federal Petroleum Usage in FY $1994 \ldots \ldots \ldots \ldots \ldots \ldots$

Table 3 Agency Expenditures for Energy Conservation Retrofits and Capital Equipment, FY 1985 through FY $1994 \ldots \ldots \ldots \ldots .24$

Table 4 Federal Energy Consumption in Buildings and Facilities ....... 38

Table 5 Petroleum-Based Fuel Consumption in Buildings and Facilities . . 44

Table 6-A Defense and Civilian Federal Costs for Buildings Energy in FY 199442

Table 6-B Consumption and Costs of Federal Buildings Energy by Fuel Type in FY 1994, FY 1993, and FY $1985 \ldots \ldots \ldots \ldots 43$

Table 7 Federal Buildings and Facilities Use

Per Gross Square Foot, FY 1985 and FY $1994 \ldots \ldots \ldots \ldots \ldots 45$

Table 8 Federal Energy Consumption in Excluded Baildings/

Process Operations . . . . . . . . . . . . . . 50

Table 9 Defense and Civilian Federal Costs for Excluded Buildings'

Process Energy in FY $1994 \ldots \ldots \ldots \ldots \ldots \ldots \ldots \ldots \ldots$. 52

Table 10 Federal Energy Consumption in Vehicle and Equipment Operations 55

Table 11-A Defense and Civilian Federal Costs for Vehicle and Bquipment

Energy in FY $1994 \ldots \ldots \ldots \ldots \ldots \ldots \ldots \ldots \ldots \ldots \ldots$. . . . . . . . . 57

Table 11-B Consumption and Costs of Vehicle and Equipment Energy

by Fuel Type in FY 1994, FY 1993, and FY $1985 \ldots \ldots \ldots \ldots .58$

Table 12 Federal Agency Progress Toward the Goals of Section 10 of

Executive Order 12759, FY 1991 and FY $1994 \ldots \ldots \ldots \ldots .59$

Table C Federal Energy Expenditures and Cost Avoidance,

FY 1985 through FY 1994

Table D-1 Total Energy Consumption by Federal Agencies -

Source Conversion $\ldots \ldots \ldots \ldots \ldots \ldots \ldots \ldots \ldots \ldots, \mathrm{D}-2$

Table D-2 Federal Buildings and Facilities Use Per Gross Square Foot -

Source Conversion, for FY 1985 and FY $1994 \ldots \ldots \ldots \ldots$ D-3

Table D-3 Federal Energy Consumption in Buildings and Facilities -

Source Conversion $\ldots \ldots \ldots \ldots \ldots \ldots \ldots \ldots \ldots \ldots$ D.4 


\section{FIGURES}

Figure ES-1 Energy Efficiency Funding in Buildings and

Annual Cost Avoidance from $1985 \ldots \ldots \ldots \ldots \ldots \ldots \ldots 2$

Figure ES-2 Decrease in Btu per Gross Square Foot in Federal

Buildings and Facilities from $1985 \ldots \ldots \ldots \ldots \ldots \ldots \ldots$

Figure ES-3 Federal Consumption of Petroleum-Based Fuels

1985 through $1994 \ldots \ldots \ldots \ldots \ldots \ldots \ldots \ldots \ldots \ldots \ldots .4$

Figure 1 Federal Energy Consumption, FY $1994 \ldots \ldots \ldots \ldots \ldots \ldots \ldots 13$

Figure 2 Federal Energy Costs, FY $1994 \ldots \ldots \ldots \ldots \ldots \ldots \ldots \ldots \ldots$

Figure 3 Energy Conservation Retrofit Expenditures . . . . . . . . 25

Figure 4 Defense and Civilian Federal Energy Consumption

in Buildings \& Facilities by Fuel Type, FY $1994 \ldots \ldots \ldots \ldots, 37$

Figure 5 Consumption of Electricity and Other Foels

in Buildings and Facilites, FY 1985 through FY $1994 \ldots \ldots$. . 39

Figure 6-A Energy Expenditures (Nominal Dollars) in Buildings

\& Facilities, FY 1985 throngh FY $1994 \ldots \ldots \ldots \ldots \ldots \ldots$. . 40

Figure 6-B Energy Expenditures (Constant Dollars) in Buildings

\& Facilities, FY 1985 throngh FY $1994 \ldots \ldots \ldots \ldots$. . . . . . 40

Figure 7 Federal Govemment Progress Toward the Mandated Energy

Reduction Goals for Buildings and Facilities,

FY 1985 through FY $1994 \ldots \ldots \ldots \ldots \ldots \ldots \ldots \ldots \ldots 44$

Figure 8 Range of Energy Intensity (Btu/GSF) in Buildings and Facilities by Agency in FY $1994 \ldots \ldots \ldots \ldots \ldots \ldots \ldots \ldots \ldots$

Figure 9 Defense and Civilian Federal Energy Consumption

in Vehicles and Equipment by Fuel Type, FY $1994 \ldots \ldots \ldots \ldots$. 56

Figure C Federal Government Average Annual Energy Costs,

FY 1985 through FY $1994 \ldots \ldots \ldots \ldots \ldots \ldots \ldots \ldots$ C-3

\section{APPENDICES}

Appendix A List of Authorities $\ldots \ldots \ldots \ldots \ldots \ldots \ldots \ldots \ldots \ldots$ A.1

Appendix B Data Collection $\ldots \ldots \ldots \ldots \ldots \ldots \ldots \ldots \ldots \ldots \ldots$ B-l

Appendix C Federal Energy Expenditures and Cost Avoidance

FY 1985 through FY $1994 \ldots \ldots \ldots \ldots \ldots \ldots \ldots \ldots$ C-1

Appendix D Federal Performance Utilizing "Source" Conversion Factors ..... D-1

Appendix E Butldings Exempted From NECPA's Performance Goal in FY 1994 E-1

Appendix F Department of Energy: Education, Extension, and

Information Services $\ldots \ldots \ldots \ldots \ldots \ldots \ldots \ldots \ldots \ldots$, F-1

Appendix $G$ Federal Agency Energy Management Contacts ......... G-1

Appendix $H$ Personnel of Department of Energy's Office of Federal

Energy Management Programs $\ldots \ldots \ldots \ldots \ldots \ldots \ldots$ H-1 


\section{AGENCY ACRONYMS}

Commodity Futures Trading Commission CFTC

Department of Agriculture

USDA

Department of Commerce

DOC

Department of Defense

DoD

Department of Energy

DOE

Department of Health and Human Services

HHS

Department of Housing and Urban Development HUD

Department of the Interior

DOI

Department of Jostice

DOJ

Department of Labor

DOL

Department of State

ST

Department of Transportation

DOT

Department of the Treasury

Department of Veterans Affairs

TRSY

Environmental Protection Agency

VA

EPA

Equal Employment Opportunity Commission

Federal Communtications Commission

EEOC

FCC

Federal Emergency Management Agency

FEMA

Federal Energy Regulatory Commission

FERC

Federal Trade Commission

FTC

General Services Administration

GSA

National Aeronautics and Space Administration

NASA

National Archives and Records Administration

NARA

National Science Foundation

NSF

Nuclear Regulatory Commission

NRC

Office of Personnel Management

OPM

Panama Canal Commission

$\mathrm{PCC}$

Railroad Retirement Board

RRB

Tennessee Valley Authority

United States Information Agency

TVA

United States Postal Service

USIA

USPS 


\section{EXECUTIVE SUMMARY}

This report on Federal Energy Management for Fiscal Year (FY) 1994 provides information on energy consumption in Federal buildings and operations and documents activities conducted by Federal agencies to meet the statutory requirements of Title V, Part 3, of the National Energy Conservation Policy Act (NECPA), as amended, 42 U.S.C. \& 8251-8261, and Title VIII of NECPA, 42 U.S.C. \$ 8287-8287b. This report also describes the energy conservation and management activities of the Federal Govenment under the authorization of section 381 of the Energy Policy and Conservation Act (EPCA), as amended, 42 U.S.C. \& 6361. Implementation activities undertaken during FY 1994 by the Federal agencies under the Energy Policy Act of 1992 (BPACT) and Executive Order 12759 on Rederal Energy Management are also described in this report.

Executive Order 12902, Energy Efficiency and Water Conservation at Federal Facilities, was signed by President Clinton on March 8, 1994, the middle of FY 1994. Initial activities implementing the Executive Order are discussed in this report. A fall reporting of activities under the Executive Order will be contained in the next annual report for FY 1995.

During FY 1994, the total (gross) energy consumption of the Government of the United States, including energy consumed to produce, process, and transport energy, was 1.72 quadrillion British Thermal Units (quads). ${ }^{1}$ These 1.72 quads consumed by the Government in buildings, facilities, and operations to provide essential services to its citizens, including the defense of the Nation, represent approximately 2.0 percent of the total 85.34 guads ${ }^{2}$ used in the United States. In total, the Federal Govemment is the single largest energy consumer in the Nation, although its pattern of consumption is widely dispersed.

Based on reports submitted to DOE by 28 Federal agencies, the Federal Government consumed 1.20 quads during FY 1994 when measured in terms of energy actually delivered to the point of use. This report uses the site-measured conversion factors for electricity and steam. Information on gross energy consumption of the Government utilizing source-messured conversion factors is provided in Appendix D. The total net energy consumption in FY 1994 decreased 16.9 percent from the FY 1985 base year, a reduction of 244.6 trillion Bto. This reduction of 244.6 trillion Btu could satisfy the energy needs of the State of Vermont for over 2 years. ${ }^{3}$ The Govemment consumes slightly more energy than the entire State of Alabama.

'Gross etergy coosumption considers all resources used to generute and transport electricity and steam. The source conversion factors of 11,600 Bto per kilowatt hour for electricity and 1,390 Btu per poind of steann are used to calculate gross energy consumption. See Appendix D.

${ }^{2} \mathrm{DOOE}$ ELA-0035(95/03), Monthly Energy Review, March 1995.

'Based on net energy consumption estimates for 1992 in the residential, conmerciad, inciustrial, and iransportation sectors (103.8 trilfion Bto). Source: DOE/ELA-0214(92), Slate Energy Data Report, 1992, Tables 1, 7, 8, 9, and 10; May 1994.

${ }^{4}$ Based on net energy consumption estimates for 1992 in the residential, coumercial, indusitial, and transpontation sectors (1,200.7 trilion B(u). Source. DOEEIA-0214(92), Siate Eivergy Data Repor, 1992, Tables 1, 7, 8, 9, and 10; May 1994. 
The total cost of the 1.20 quads was approximately $\$ 8.0$ billion in FY 1994 . This is $\$ 2.4$ billion less than the $\$ 10.4$ bitlion reported in FY 1985, a 22.9 percent decresse in nominal costs. In constant 1987 dollars, this equates to a decrease of 42.3 percent from $\$ 11.1$ billion in FY 1985 to $\$ 6.4$ billion in FY 1994. The Federal energy bill for FY 1994 decreased $\$ 899.3$ million from the $\$ 8.9$ billion reported for FY 1993 .

Federal agencies report energy consumption under three categories: buildings and facilities, energy intensive operations, and vehicles and equipment.

\section{Butldings and Facilities}

In FY 1994, the Federal Govemment used 385.0 trillion British Thenmal Units (Btu) to provide energy to approximately 500,000 buildings and facilities. This consumption represents an 18.2 percent decrease compared to FY 1985 and a 4.5 percent decrease relative to FY 1993 as displayed in Table 4. The nominal cost of energy for buildings and facilities in FY 1994 was $\$ 3.8$ billion, a decresse of approximately $\$ 91.8$ million from FY 1993 expenditures, and a decrease of 4.0 percent from the FY 1985 expenditure of almost $\$ 4.0$ billion. In constant dollars, energy costs for buildings and facilities decreased 28.2 percent from $\$ 4.2$ billion in FY 1985 to $\$ 3.0$ billion in FY 1994.

In FY 1994, direct appropriated funding identified by agencies for energy conservation retrofits and capital equipment increased $\mathbf{9 0 . 5}$ percent from $\$ 120.9$ million in FY 1993 to $\$ 230.2$ million. FY 1995 funding is projected at $\$ 354.2$ million based upon reports from the agencies.

Figure ES-1 compares direct Federal funding for energy efficiency with the annual cost avoided from 1985 for buildings and facilities energy. From 1985 through 1994, investments of almost $\$ 1.3$ billion for energy efficiency in buildings contritonted to a cumalative cost avoidance of $\$ 3.6$ billion (see Table 3 and Appendix ().
FIGUAE ES-I

Bnergy Caficiency Funding in Buildings and Antutal Cost Avoidance frotn 1985

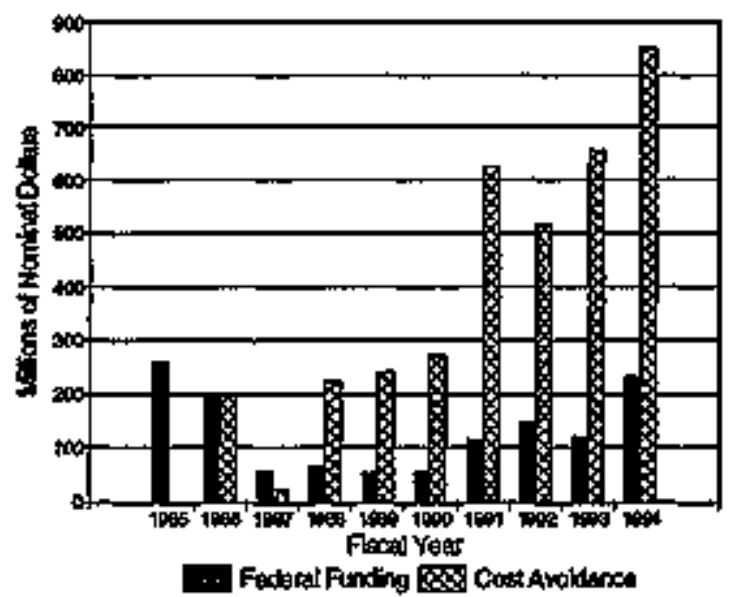

\section{Energy Intensive Operations}

The energy intensive operations category covers energy used in butindings excluded from the 10 and 20 percent reduction goals for buildings and facilities under section 543 of NECPA. This category includes the energy consumed in industrial operations, certain R\&D activities, and in electronic-intensive facilities.

\footnotetext{
sCalculation of percent changes do not account for toundiug of numbers in text.

Cost and consumption figures for FY 1985 may be differents from those published in last year's Ammul Report since Federal agencies update their files and provide revisions to their dath.
} 
In FY 1994, the Federal Govemment used 93.1 trillion Bto of energy in energy intensive operations, approximately 7.8 percent of the total 1.20 quads consumed. Total energy consumption in this category increased 132.2 percent relative to FY 1985 and 31.5 percent relative to FY 1993. This increase is primarily the result of changes in reporting procednres by individual agencies.

The Federal Government spent $\$ 975.3$ million on operations energy in FY 1994, $\$ 371.0$ million more than the FY 1993 expenditure of $\$ 604.3$ million.

\section{Vehicles and Equipment}

The vehicles and equipment category includes aircraft and naval fuels, automotive gasoline and diesel fuel consumed by Federally-owned and leased vehicles and privately-owned vehicles used for official business, and the energy used in Federal construction.

In FY 1994, the Federal Government used an estimated 722.9 trillion Btu of energy in vehicles and equipment, approximately 60.2 percent of the total 1.20 quads consumed. Total energy consumption in vehicles and equipment decreased 22.7 percent relative to FY 1985 and 6.6 percent relative to FY 1993. The Department of Defense consumed 674.6 trillion Btu ar 93.3 percent of all vehicles and equipment energy used by the Federal Govemment.

The Federal Government spent apptoximately $\$ 3.3$ billion on vehicles and equipment energy in FY 1994, almost $\$ 1.2$ billion less than the FY 1993 expenditure of $\$ 4.4$ billion. FY 1994 is the first year in the history of Federal energy reporting (since 1975), that the cost of vehicle and equipment fuel was lower than the cost of energy used in buildings and facilities.

During FY 1994, the General Services Administration procured 3,93I alternative fuel vehicles (AFVs). Direct AFV purchases by the Departments of Defense, Energy, Commerce, the Interior, and Agriculture accounted for 132 additional vehicles. In FY 1994, AFV purchases totalled 4,063 vehicles.

\section{Agency Progress in Meeting Energy Reduction Goals}

NECPA, as ameaded by EPACT, requires agencies to take the steps necessary to reduce energy consumption in Federal buildings by

10 percent by 1995 compared to 1985

consumption levels, based on Bú per gross square foot and requires a 20 percent reduction by 2000 compared to 1985 consumption levels. Executive Order 12902 adds an additional goal of reducing energy consumption by 30 percent by the year 2005 relative to 1985 consumption levels. During FY 1994 agencies provided data to DOE that indicated a decrease in energy consumption per gross square foot by 11.2 percent relative to FY 1985 . The Government's performance for each year since FY 1985 is illustrated in Figtre ES-2. This

\section{FIGURE ES-2}

Decresse in Btu per Gross Square Font in Federal Bulldings and Facilitles from 1985

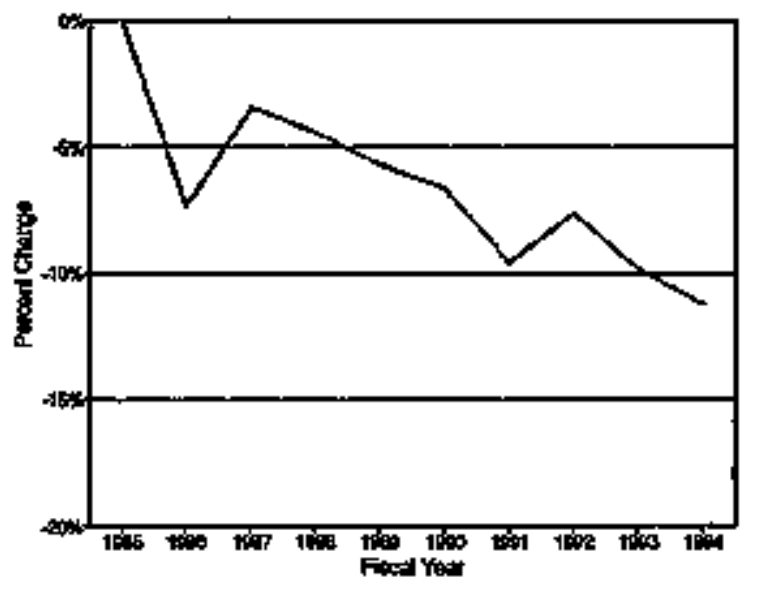


zeduction was the result of significent decreases in the consumption of foel oil, natural gas, and coal. Although the use of non-electric fuels in Federal buildings has declined approximately 29.7 percent since 1985 , the consumption of electricity has increased approximately 7.7 pencent. The increase in electricity may result from the installation and increased use of electricity-driven electronic equipment. Electricity now represents about 71.2 percent of the total energy costs of Federal buildings and accounts for $\mathbf{4 0 . 4}$ percent of total energy consumption in buildings. This is compared to 30.7 percent of the total energy consamption in boildings in FY 1985.

Agency efforts undertaken in FY 1994 to increase energy efficiency in buildings included:

- improvement of operations and maintenance procedures;

- implementation of no-cost, low-cost efficiency measures;

- energy-efficient building retrofits and capital improvements;

- energy awareness activities and employee training programs;

- procurement of energy-efficient goods and products.

Executive Orter 12902 expands the scope of Federal energy management activities beyond the NECPA mandates by establishing goals for industrial operations. Section 301(b) of Executive Order 12902 requires agencies to implement programs in industrial facilities to increase energy efficiency by 20 percent in FY 2005 in comparison to FY 1990 consumption levels to the extent that measures undertaken to achieve the goal are cost-effective.

Section 10 of Executive Order 12759 directs each agency operating at least 300 commercially designed motor vehicles domestically to develop a plan to reduce gasoline and diesel consumption by 10 percent between FY 1991 and FY 1995. The Administrator of General Services, in consultation with the Secretary of Energy, has issued guidance to assist agencies in meeting this goal. During FY 1994, gasoline consumption by the agencies decreased 12.9 gercent to 237.1 million gallons from 272.2 million gallons in FY 1991. Diesel consumption decreased 14.7 percent in FY 1994 to 980.4 million gallons compared to 1,150.0 million gallons consumed in FY 1991. Diesel fuel consumption data reported by the agencies includes fuel used in off-road vehicles and equipment as well as on-road passenger cars and trucks.

Procurement of Energy-Efficient Products

Section 507 of Executive Order 12902 requires all Federal agencies to boy "best practice" products, when practicable and cost-effective. Best practice products are those which ane in the upper 25 percent of energy efficiency for all simitar products, or products that are at least 10 percent more efficient than the minimum level that meets Federal standards. During FY 1994, DOE initiated a program to assist agencies in implementing the EPACT and Executive Order reguirements for energy efficient procurement.

\section{Reducing Petroleum-Based Fuel Consumption}

Effective management of energy resources is of strategic importance to the Federal Government as well as the Nation. In FY 1994, petroleum-based fuels accounted for 0.79 quads of the total 1.20 quads consumed by the Federal Govenment. Of that, 0.73 quads were used by the Department of Defense primarily for jet fuel and distillate/diesel for vehicles and equipment The Govermment consumed 24.9 percent less petroleum-based fuel in FY 1994 than in FY 1985. Figure ES-3 illustrates the trend in the Government's use of petroleum fuels. 
Due to the strategic nature of petroleum-based fuels, Executive Order 12902 directs agencies to minimize the use of petroleum-based fuels in buildings and facilities. Federal agencies have made significant progress in reducing their dependence on petroleum-based fuels in their buildings and facilities. For example, Federal agencies report that in FY 1994, 60.7 trillion Btu of petroleun-based fuels were used for buildings and facilities energy, a 45.4 percent decrease from FY 1985 and a 7.3 percent decrease from FY 1993. This represents almost 15.8 percent of total buildings and facilities energy consumption.

\section{Federal Energy Management Highlights}

Progress is being made in increasing Federal energy efficiency. Although there remain opportunities for greater efficiency and cost reduction, several of the most important findings of this report are listed below:

- Overall cost of energy consumption in the Federal Government has fallen from $\$ 10.4$ billion in FY 1985 to $\$ 8.0$ billion in FY 1994. During this period, the Governments cumulative annual energy cost avoidance was $\$ 3.8$ billion. (See Appendix C)

- The total net energy consamption in FY 1994 decreased 16.9 percent from FY 1985.

- Energy consumption in buildings in FY 1994 decreased 18.2 percent from FY 1985.

- On a Bul-per-gross-square-foot basis, the 11.2 percent reduction in buildings energy puts the Federal Govenment past the 10 percent reduction goal for 1995.

- Ten agencies, the Departments of Agriculture, Defense, Energy, the Interior, Justice, Transportation, Veterans Affairs, the Federal Emergency Management Agency, General Services Administration, and the National Aeronautics and Space Administration have already achieved a 10 percent reduction in buildings energy use from 1985.

- Three agencies, the Departments of Energy and Justice, and the Federal Emergency Management Agency have already achieved a 20 percent reduction in boildings energy use from 1985.

- Energy consumption is used for the following purposes:

$\begin{array}{lcc}\text { End Use } & \text { Percentage } & \text { Cost } \\ \text { Buildings \& Facilities } & 32 \% & \$ 3.8 \text { billion } \\ \text { Energy Intensive Operations } & 8 \% & \$ 1.0 \text { billion } \\ \text { Vehicles \& Equipment } & 60 \% & \$ 3.3 \text { billion }\end{array}$




\section{OVERVIEW OR FEDERAL ENERGY MANAGEMENT ACTTVTTISS}

\section{A. Overview of Federal Energy Management Policy and Legislative Mandates}

This report on Federal Energy Management for Fiscal Year (FY) 1994 provides information on energy consumption in Federal buildings and operations and documents activities conducted by Federal agencies to meet the statutory requirements of Title V, Part 3, of the National Energy Conservation Policy Act (NECPA), as amended, 42 U.S.C. \& 8251-8261, and Title VIII of NECPA, 42 U.S.C. \& 8287-8287b. Implementation activities undertaken during FY 1994 by the Federal agencies under the Energy Policy Act of 1992 (EPACT) and Executive Order 12759 on Federal Energy Management are also described in this report In compliance with section 381 (c) of the Energy Policy and Conservation Act, 42 U.S.C. \& 6361(c), this report also describes the energy conservation and management activities of the Federal Government under the authorization of section 381 of the Energy Policy and Conservation Act, as amended, (EPCA), 42 U.S.C. \$ 6361.

Executive Order 12902, Energy Efficiency and Water Conservation at Federal Facilities, was signed by President Clinton on March 8, 1994, the middle of FY 1994. Initial activities implementing the Executive Order ane discussed in this report. A full reporting of activities under the Executive Order will be contained in the next annual report for FY 1995.

\section{Requirements of National Energy Conservation Policy Act (NECPA) and Energy Policy Act of 1992 (EPACT)}

NECPA provides major policy guidance to Federal agencies to improve energy management in their facilities and operations. Amendments to NECPA made by the Federal Energy Management Improvement Act of 1988 directed DOE to establish life-cycle costing methods and coordinate Federal conservation activities through the Interagency Energy Management Task Force. Section 152 of Subtitle F of EPACT, Federal Agency Energy Maragement, further amends NECPA and contains provisions regarding energy management reguirements, life-cycle cost methodology and procedures, bodget treatment for energy conservation measures, incentives for Federal agencies, reporting requirements, new technology demonstrations, and agency surveys of energy-saving potentiai.

Section 543 of NECPA, as amended by EPACT, requires each agency to achieve a to percent reduction in energy consuroption in its Federal buildings by FY 1995, when measured against a FY 1985 baseline on a Btw-per-gross-square-foot basis. It also requires a 20 percent reduction in Bou per gross square foot by FY 2000. Federal buildings include both Federally-owned and leased buildings. However, in many instances the lessor pays the energy bill, and consumption and cost data may not be available to the Government. Accordingly, Federal agencies are reporting data for leased space to the maximum extent practicable. ${ }^{7}$ Federal agencies reported

\footnotetext{
7The General Services Adninistration is the primary leasing gigent for the Feteral Government, although most of the other agencies do have some leasing authority. In some cases, GSA will delegate operations anti urintenance responsibility to individhal agexties for leased space, requiring the agency to be responsible for paying the utility bills and reporting energy consumption.
} 
an 11.2 percent decrease in energy consumption in buildings in FY 1994, compared to FY 1985, measured on a Bto-per-gross-square-foot basis.

Section 543(b) of NECPA, as amended by EPACT, requires that not later than January 1, 2005, each agency shall, to the maximum extent practicable, install in Federal buildings owned by the United States all energy and water conservation measures with payback periods of less than 10 years, as determined by using the Federal life cycle costing methods and procedures.

In order to achieve the requirements, each agency is required to:

1) prepare or update a plan describing how the agency intends to meet the requirements;

2) perform energy surveys of its Federal buildings to the extent necessary and update stich surveys as needed;

3) using such surveys, determine the cost and payback period of energy and water conservation measures likely to achieve the requirements;

4) install energy and water conservation measures that will achieve the requirements throogh Federal life cycle costing methods and procedures; and

5) ensure that operation and maintenance procedures applied under NECPA are continued.

NECPA requires DOE to establish life-cycle costing methods to determine cost-effectiveness of proposed energy efficiency projects. DOE issued a final rulemaking on life-cycle cost methods on November 20,1990. At the beginning of FY 1994, the 1994 edition of energy prices and discount factors for life-cycle cost analysis, developed with the technical assistance of the National Institute of Standards and Technology, was published and distributed to Federal energy managers.

NECPA, as amended, requires the Presidient to transmit to the Congress, along with each budget that is submitted to the Congress the amount of appropriations requested in such budget if any, on an individual agency basis, for electric and other energy costs to be incuned in operating and maintaining agency facilities; and compliance with the provisions of NECPA, the Energy Policy and Conservation Act (42 U.S.C. 6201 et sed.) and all applicable Executive Orders. Reports from Federal agencies indicated that $\$ 230.2$ million was spent in FY 1994 on energy efftciency projects in Federal facilities.

NECPA, as amended, also requires Federal agencies to establish a program of incentives to expedite Federal energy savings performance (ESP) contracts (formerly known as shared energy savings (SES) contracts), authorized under Title VIll of NECPA. These contracts can provide Federal agencies with private sector capital to finance their retrofit projects. In turn, the private sector contractor receives a share of the savings for undertaking the investment. During FY 1994, 3 ESP contracts were awarked by Federal agencies, bringing the total number of awarded contracts to 19. 
Section 546(b) of NECPA, as arnended, requires DOE to establish a Federal Energy Efficiency Fund to provide grants to agencies to assist them in meeting NECPA's energy management requirements. Section 546(c) encourages agency participation in utility incentive programs and provides for the retention of 50 percent of energy and water cost savings by agencies for additional energy efficiency measures. Information on these incentives is contained in Section IE) of this report.

Section 157 of EPACT requines Federal agencies to establish and maintain programs to train energy managers and to increase the number of trained energy managers within each agency. The Act defines a "trained energy manager" as "a person who has completed a course of study in the areas of: (1) fundamentals of building energy systems, (2) building energy codes and applicable professional standards, (3) energy accounting and analysis, (4) life-cycle cost methodologies, (5) fuel supply end pricing, and (6) instrumentation for energy surveys and audits." Training activities are discussed in Section D of this report.

DOE also coordinated activities to expedite energy efficiency by providing technical assistance and training and throngh the provision of technical and analytical models.

DOE is directed to include in this report to Congress a description of activities undertaken under section 381 of the Energy Policy and Conservation Act (EPCA). These activities are addressed in Section I(C), Federal Coordination; Section I(F), Life-Cycle Costing; and Section I(H), Public Education Programs.

\section{Requirements of Executive Orders 12759 and 12902}

During FY 1994 two Executive Orders were in effect for Federal agencies. At the beginning of FY 1994, Executive Order 12759 on Federal Energy Management provided direction to the Government's energy management activities. Signed by President Bush in Apzil 1991, it expanded the scope of Federal energy management activities beyond the NECPA reguirements to include industrial facilities and Federal vehicles. Executive Order 12902, Energy Efficiency and Water Conservation at Federal Facilities, signed by President Clinton on March 8, 1994, supersedes Executive Onder 12759 but lesves in effect sections 3, 9, and 10 of that Order. The requirements of both Orders are described below. Initial activities implementing Executive Order 12902 are discussed in this report. A full reporting of activities under the Executive Order will be contained in the next annual report for FY 1995.

\section{Reduction Goals for Buildings}

Executive Order 12759 established the 20 percent energy reduction goal for Federal buildings from 1985 to 2000 , as long as the inprovements ane cost-effective and minimize the life-cycle cost of the facility. This was later incorporated into NECPA with the passage of EPACT. Executive Order 12902 establishes a 30 percent reduction goal for Federal buildings by 2005 compared to 1985 consumption levels on a Btu-per-gross-square-foot basis.

\section{Reduction Goals for Industrial Facilities}

Executive Order 12759 established for industrial facilities a goal of 20 percent improvement in energy efficiency for Federal industrial facilities from FY 1985 to FY 2000 with each agency to develop appropriate indicators of energy efficiency for measuring progress toward the goal. 
Executive Order 12902 changes this goal to require an increase in energy efficiency by at least 20 percent by 2005 as compared to the 1990 benchmark. Measures undertaken to achieve this goal must be cost-effective, and agencies are atso directed to implement all costeffective water conservation projects.

\section{Implementation Strategy}

Executive Order 12759 allowed the agencies flexibility in adopting an implementation strategy. If ayailable resources at agencies fell short of requirements, the Order directed that energy efficiency projects should be prioritized by the savings-to-investment ratio or the adjusted internal rate of return. Executive Order 12902 provides a more structared approach to implementation. It requires agencies to conduct a prionitization survey of all facilities which carl then be used to establish priorides for conducting comprehensive facility audits. Agencies are required to implement a 10 -year plan to conduct comprehensive facility audits, so that approximately 10 percent of the agency's facilities are completed each year. Within 180 days of the completion of the comprehensive facility audit of each facility, agencies are required to begin implementing cost-effective recommendations for installation of energy efficiency, water conservation, and renewable energy technologies for that facility.

\section{Minimization of Petroleum Use in Facilities}

Section 3 of Executive Order 12759 directs agencies to minimize the use of petroleum prodocts for facilities operations or building purposes through switching to an alternative energy source if it is estimated to minimize life cycle costs and which will not violate Federal, State, or local clean air standards. Executive Order 12902 also contains this requirement but further directs agencies to improve the efficiency with which they use the petroleum in facilities where alternative fuels are not practical or cost-effective. Both Executive Orders require agensies to survey buildings and facilities that utilize petroleum-based fuel systems to determine where the potential for a doal-fuel capability exists and provide dual-fuel capability where cost-effective and practicable.

\section{Procurement of Energy-Efficient Products}

Executive Order 12759 directed each agency to require vendors of goods to provide data that could be used to assess the life-cycle costs of goods, including building energy system components, lighting systems, of fice equipment, and other energy-using equipment. Executive Order 12902 expands the scope of activities in this area by directing agencies to strive to purchase products in the top 25 percent of their class for energy efficiency, wherever such products are cost-effective and meet the agency's performance requirements. It also contains provisions for a "Federal Procurement Challenge" isviting each Federal agency to comnit a specified fraction of their purchases to advanced energy-efficient and water-conserving technologies that are technically and commercially feasible but not yet available on the open market. The Government's activities to emphasize energy efficiency in procurement policy is detailed in Section IF $F$ of this report

\section{Energy Performance Standards for Buildings/Showcases}

Executive Order 12759 directed agencies to implement all applicable rules and regulations in current Federal buildings space and to comply with applicable energy pefformance standards for the construction of new Federal buildings. Executive Order 12902 strengthens this provision to ensure that the design and construction of facilities meets or exceeds the energy performance 
standards applicable to Federal buildings, local building standards, or a Btu-per-gross-squarefoot ceiling, whichever will result in a lower life cycle cost over the life of the facility.

Information of the status of Federal boilding energy performance standards is contained in Section $\Pi(C)$ of this report

Exectrive Order 12902 also contains provisions for the establishment of agency facility commissioning programs and obligates agencies to designate new and existing buildings to showcase the best energy and water efficiency, and renewable energy technologies to the poblic.

Energy-Eficiency Goal for Vehicles

Seccion 10 of Executive Order 12759 establishes an energy-efficiency goal for Federal vehicles. Each agency operating at least 300 commercially designed motor vehicles domestically is directed to develop a plan to reduce gasoline and diesel consumption by 10 percent by FY 1995 in comparison to FY 1991. Agency progress toward the gasoline and diesel reduction goals is detailed in Section IV(B) of this report.

\section{Altemative Fuel Vehicles}

Section 11 of Executive Order 12759 establishes requirements for the acquisition of altemative fuel motor vehicles by the end of model year 1995. Agencies electing to use these vehicles receive credit towand meeting the vehicle energy efficiency goal. Information on Federal Govemnent activities related to alternative fuel vehicles is included in Section IV(C) of this report-

\section{B. Orerall Federal Energy Consumption and Costs}

During FY 1994, the total (gross) energy consumption of the Government of the United States, including energy consuned to produce, process, and transport energy, was 1.72 quadrillion British Thermal Units (quads). ${ }^{8}$ These 1.72 quads represent 2.0 percent of the total 85.34 quads $s^{9}$ used in the United \$tates, and reflect Govemment energy consnmption in buillings, facilities, and operations to provide essential services to its citizens, including the defense of the Nation. In total, the Federal Government is the single largest energy consumer in the Nation, although its pattern of consumption is widely dispersed.

Based on reports submitted to DOE by 28 Federal agencies, the Government consumed 1.20 quads during FY 1994 when measured in terms of energy actually delivered to the point of use. As shown in Table 1, Federal agencies reported a 16.9 percent decrease in total net energy consumption compared to FY 1985, and a 3.8 percent decrease from FY 1993. The cost of this energy was $\$ 8.0$ billion and represented approximately 0.6 percent of the total Federal

\footnotetext{
"Gross energy consumption considers all resounces used to generate and transport electricity and steam. The source corversion factors of 11,600 Bin per kilowatt hour for electrictily and 1,390 Btu per pound of stean are used to calculate gnoss energy consamption. See Appendix D.

'DOEIEIA-0035(9503), Konthly Energy Revtew, March 1995.
} 
expenditures of $\$ 1.461$ trillion ${ }^{10}$ for all purposes in FY 1994. The Federal energy bill for FY 1994 decreased approximately $\$ 899.3$ million from the $\$ 8.9$ billion reported for FY 1993."

In FY 1994, the Department of Defense spent \$5.7 billion for energy of the total Federal energy expenditure of $\$ 8.0$ billion. Overall, the Department of Defense used 21.9 percent less energy in FY 1994 than in FY 1985. The Department of Energy continues to be the largest consumer of energy among civilian agencies, due to its involvement in energy-intensive nuclear research and weapons development

Figares 1 and 2 depict the percentage of total energy used by the Federal Government in FY 1994 and its cost. As illustrated, jet fuel and electricity account for approximately 63.7 percent of the total energy consumption represented in Figure $I$ and approximately 74.6 percent of the total energy costs in Figure 2.

The strategic importance of petroleum-based fuels to the Federal Government is shown in Table 2. In FY 1994, petroleum-based fuels accounted for 0.79 quads of the total 1.20 quads consumed by the Federal Government. Of that, approximately 0.73 quads were used by the Department of Defense primarily for jet fuel and distllate/diesel for vehicles and equipment energy. Only 0.06 guads of petroleum-based fuels were used for Federal buildings and facilities energy.

\footnotetext{
I0Sowfce: Office of External Affairs, Office of Maragement and Bndget.

"Appendix C indicates the annual cost of energy used in Federal buildings and facilities, vehicles and egujpment, and epergy tntenstye operalions for FY 1985 through FY 1994. Federal energy cost avoidance is also represented, based on the value of annual energy savings in thep-year dollars. The average unit cost for energy in each fiscal year is depicted in Figure $C$ of Appendix $C$.
} 
TABLE 1

TOTAL NET ENERGY CONSUMPTHON BY FEDERAL AGENCIES

(In Billions of British Thermal Units, Millions of Barrels of Oil Equivalent [MBOE], and Petajoules [Jonle $x 10^{15}$ ])

\begin{tabular}{|c|c|c|c|c|c|c|c|c|c|c|c|c|}
\hline $\begin{array}{l}\text { CIVILIAN } \\
\text { AGENCY }\end{array}$ & ${ }_{2965}^{T Y}$ & $\begin{array}{c}F Y \\
1966\end{array}$ & $\begin{array}{c}\text { PX } \\
1967\end{array}$ & 199. & 1969 & IFo & $\begin{array}{c}\mathbf{F r} \\
1991\end{array}$ & $\underset{1092}{\mathbb{Y}}$ & 19.83 & $\begin{array}{c}\text { FY } \\
1994\end{array}$ & $\begin{array}{l}\text { с скинав } \\
\text { 95-94 }\end{array}$ & $+\lg _{\text {glumge }}$ \\
\hline 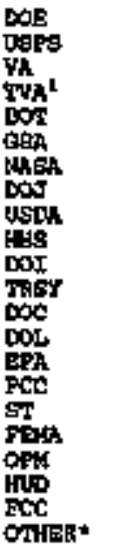 & 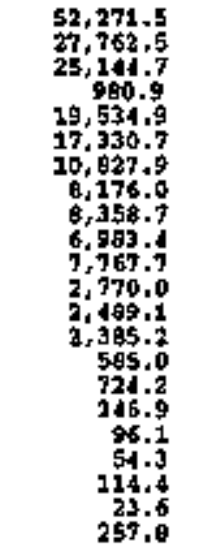 & $\begin{array}{r}49,930.5 \\
26,036.6 \\
25,020.9 \\
902.6 \\
19,394.0 \\
14,003.0 \\
13,166,8 \\
8,592.7 \\
6,797.9 \\
6,219.9 \\
6,953.9 \\
2,797.1 \\
7,274.6 \\
2,116.0 \\
1,273.1 \\
605.9 \\
264.7 \\
151.9 \\
54.5 \\
117.4 \\
22.8 \\
342.6\end{array}$ & 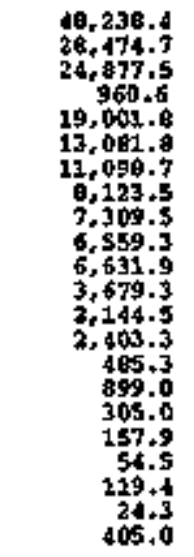 & 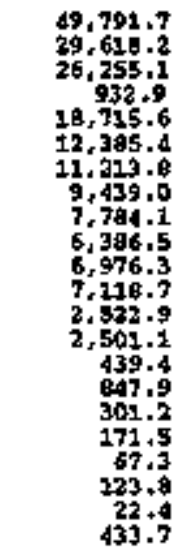 & $\begin{array}{r}13,602.3 \\
30,306,7 \\
26,249.3 \\
018.0 \\
16,507.2 \\
12,659.5 \\
12,102.7 \\
7,749.4 \\
9,667.1 \\
6,729.3 \\
7,949.8 \\
5,242.4 \\
2,959.2 \\
2,430.1 \\
439.3 \\
916.3 \\
302.9 \\
192.5 \\
77.1 \\
139.2 \\
20.6 \\
1,959.4\end{array}$ & 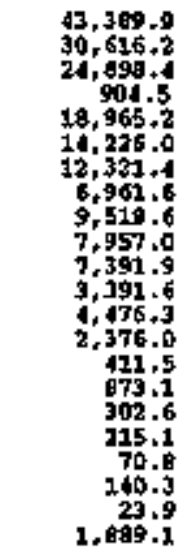 & $\begin{array}{r}41.779 .9 \\
30.617 .0 \\
25.050 .4 \\
961.3 \\
17.863 .7 \\
13.956 .9 \\
12.435 .4 \\
6.016 .3 \\
9.599 .6 \\
7.107 .1 \\
7.094 .6 \\
1.177 .1 \\
2,722.2 \\
2,406.0 \\
426.4 \\
006.1 \\
274.2 \\
198.4 \\
74.6 \\
162.3 \\
27.1 \\
1,109.0\end{array}$ & 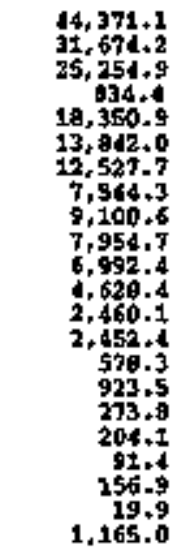 & 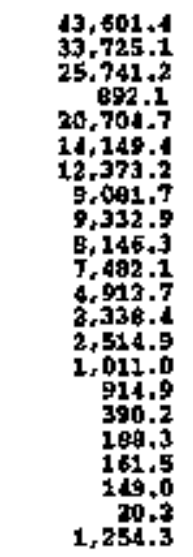 & 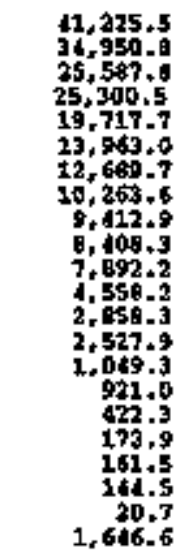 & $\begin{array}{r}-21.1 \\
25.9 \\
1.9 \\
2.479 .3 \\
0.9 \\
-19+4 \\
17.3 \\
25.5 \\
12.5 \\
20.4 \\
1.6 \\
64.5 \\
14.8 \\
5.0 \\
77.4 \\
27.2 \\
71.0 \\
86.0 \\
197.3 \\
26.3 \\
-12.1 \\
530.6\end{array}$ & $\begin{array}{r}-5.1 \\
3.6 \\
-0.6 \\
2.736 .1 \\
-4.8 \\
-1.3 \\
2.6 \\
13.0 \\
0.9 \\
3.2 \\
5.5 \\
-7.5 \\
22.3 \\
0.5 \\
3.8 \\
0.7 \\
0.2 \\
-9.2 \\
0.0 \\
-3.6 \\
3.7 \\
31.3\end{array}$ \\
\hline $\begin{array}{l}\text { CIVI LThN } \\
\text { DOTEL }\end{array}$ & $\begin{array}{l}\text { MAExifes } \\
194+685,7\end{array}$ & $187,336,9$ & $186,035.1$ & $39 d_{s} 048.5$ & 189.284 .1 & 191.921 .9 & $107,304.7$ & 191، 400.0 & $109,005.5$ & $223,095.3$ & 14.9 & 12.5 \\
\hline 000 & $1,250,613,8$ & $2,282,801,5$ & $1,280,539+2$ & $1,165,755.3$ & $1.234,043,6$ & $1,241,655.0$ & $1.269,291.5$ & $1.503,990.1$ & $1,049,772.9$ & 977.040 .4 & -21.9 & -6.8 \\
\hline 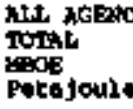 & $\begin{array}{r}\text { CIEs } \\
1,415,499.5 \\
0 \quad 1,340.2 \\
0 \quad 1,34.9\end{array}$ & $\begin{array}{r}1,410,238+4 \\
212,1 \\
1,487,6\end{array}$ & $\begin{array}{r}1,465,574+3 \\
251+6 \\
1.546 .1\end{array}$ & $\begin{array}{r}1,359,903 \times 8 \\
233,44 \\
1,434 \times 5\end{array}$ & $\begin{array}{r}1.463 .729 .7 \\
231.3 \\
1.5 d 4.2\end{array}$ & $\begin{array}{r}1,433.977 .9 \\
246.0 \\
2,311.7\end{array}$ & $\begin{array}{r}7,455,396.2 \\
250.0 \\
1,336.4\end{array}$ & $\begin{array}{r}2.295,391.0 \\
222.4 \\
1,366.6\end{array}$ & $\begin{array}{r}1,247,25 \mathrm{a}, 4 \\
21,4,2 \\
1,316.4\end{array}$ & $\begin{array}{r}1,200,935.7 \\
296.7 \\
1,266.9\end{array}$ & -16.9 & -3.8 \\
\hline 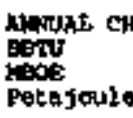 & HANGE EROA 7985 & $\begin{array}{r}-35,361+1 \\
-8 .+1 \\
-37.3\end{array}$ & $\begin{array}{r}20,074.9 \\
3+1 \\
21.2\end{array}$ & $\begin{array}{r}-86,695.7 \\
-14+7 \\
-90+4\end{array}$ & $\begin{array}{r}16.226,2 \\
3+1 \\
+9.2\end{array}$ & $\begin{array}{r}-12,521.7 \\
-2 .+1 \\
-13.2\end{array}$ & $\begin{array}{r}10,896.7 \\
1.9 \\
12.5\end{array}$ & $\begin{array}{r}-150,108.3 \\
-25.8 \\
-158.4\end{array}$ & $\begin{array}{r}-197,641.0 \\
-33.8 \\
-209.5\end{array}$ & $\begin{array}{r}-24 t .963 .7 \\
-42.0 \\
-250.0\end{array}$ & & \\
\hline 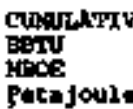 & VE SAVINASS EROW & $\begin{array}{r}1995 \\
35.361 .1 \\
6 \% .1 \\
37.3\end{array}$ & $\begin{array}{r}15.286+2 \\
2.6 \\
16.1\end{array}$ & $\begin{array}{r}100,981.9 \\
17.3 \\
106.5\end{array}$ & $\begin{array}{r}93.753 .7 \\
14.2 \\
97.3\end{array}$ & $\begin{array}{r}95,775.4 \\
16.4 \\
100.5\end{array}$ & $\begin{array}{r}04,379.7 \\
14.5 \\
69.0\end{array}$ & $\begin{array}{r}234,497.2 \\
40.5 \\
247.4\end{array}$ & $\begin{array}{r}432,129.2 \\
74.2 \\
455.9\end{array}$ & $\begin{array}{r}676.592 .0 \\
115.2 \\
713.9\end{array}$ & & + \\
\hline
\end{tabular}

"Other includes, for certain years, Commostity Futures Trading Conemission, Equal Enployment Opportunity Commission, Federal Trade Commission, Notional Anctives und

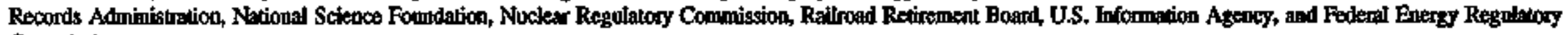
Commission.

'TVA's large lacnease in energy consaimption for FY 1994 is the result of fist-time repunting of electricity consumed at power plants for station service use.

Note: $\quad$ FY 1994 comians estinated data for the following agencies: Departments of the Treasury, Federal Trade Counission, and Ofice of Persomel Management

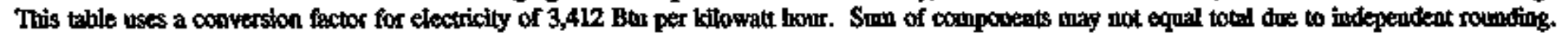

Source: Federal Agency Arnuad Energy Maagement Data Reports 


\section{FIGURE 1}

Federal Energy Consumption, FY 1994

TOTAL

1.20 quads

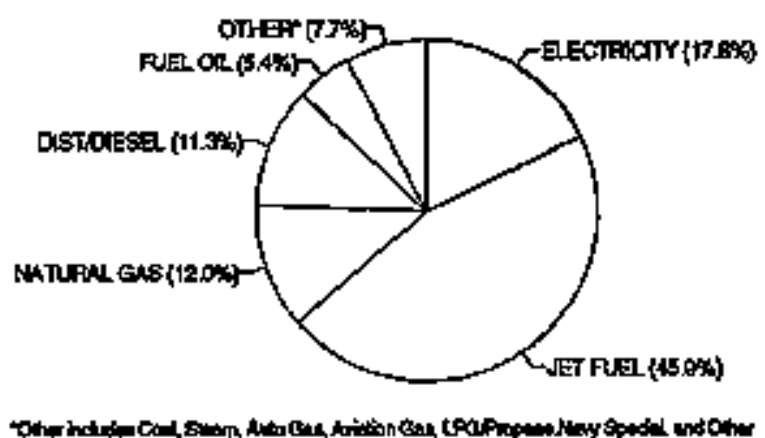

\section{BUIIDINGS AND \\ FACILTTIES \\ 0.38 quads}

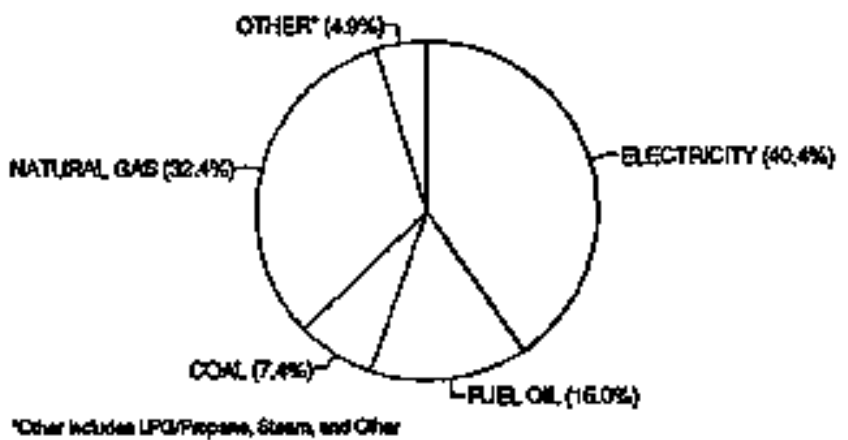

VEHICLES \&

EQUIPMENT/

ENERGY

INTENSTVE

OPERATIONS

0.82 quads

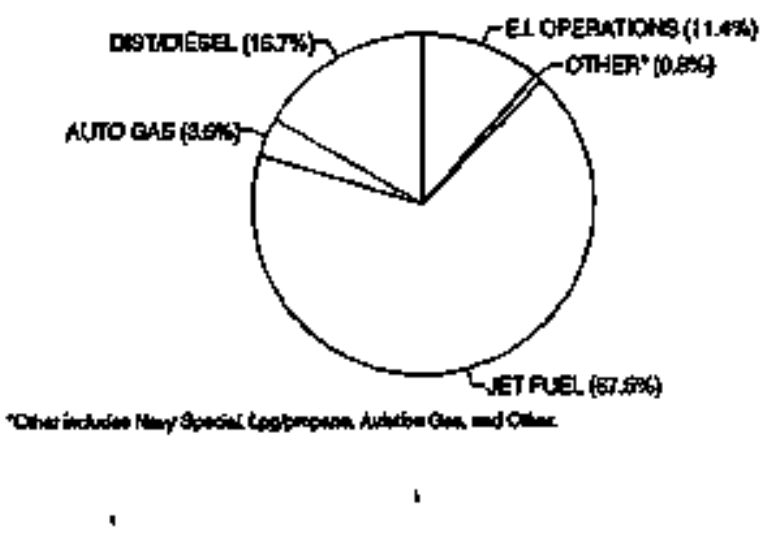

Data as of $07 / 20 / 95$

Source: Federal Agency Anpual Energy Manggemeetx Data Reports

Note: Swo of components may not equal total doe to indeperdent rounding. 
FIGURE 2

Federal Energy Costs, FY 1994

(Nominal Dallars)

TOTAL

$\$ 8.05$ Billion

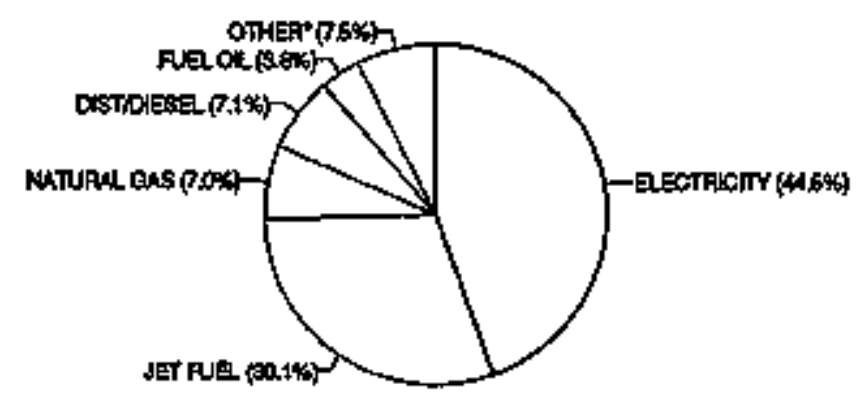

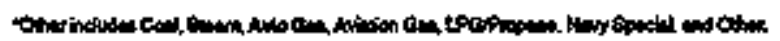
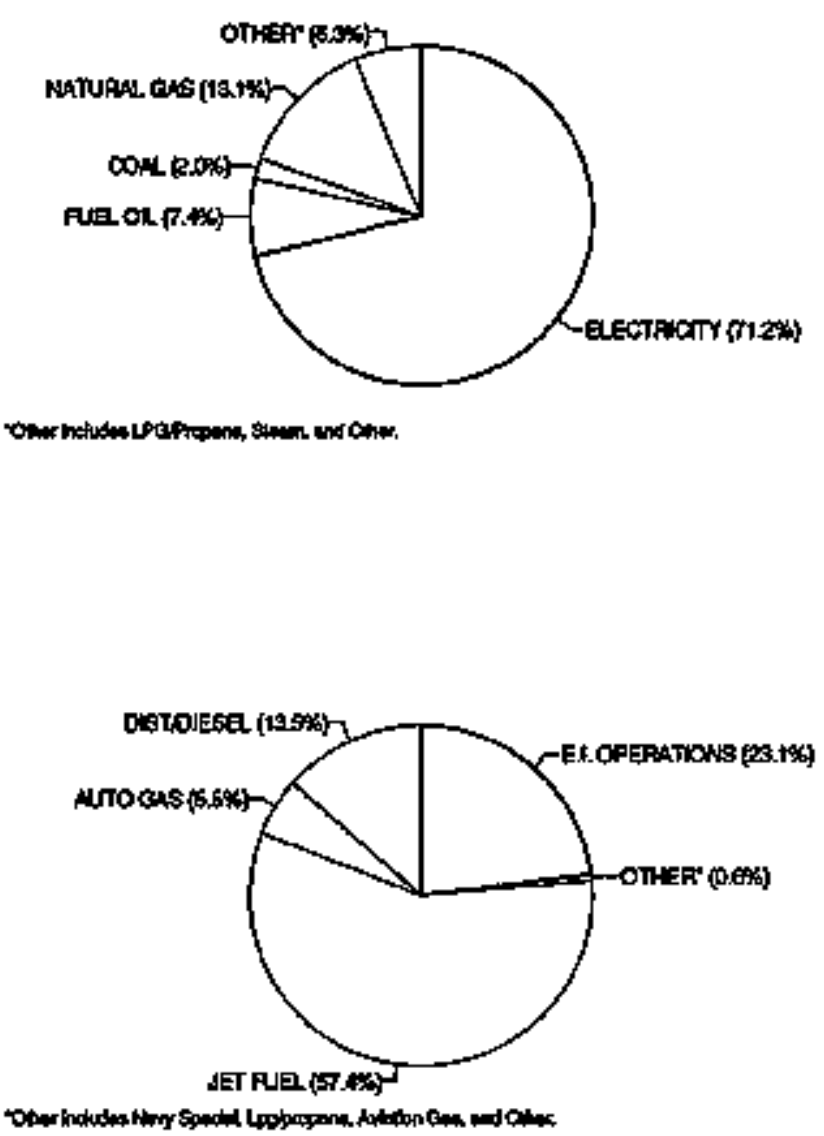

VEHFCLES \& EQUIPMENT/

ENERGY

INTENSIVE

OPERATIONS

$\$ 4.23$ Billion

BUILDINGS AND

FACILITIES

$\$ 3.82$ Billion

Data as of $07 / 20 / 95$

Source: Amoul etretgy cost data submitted to DOE by Pederal agencies.

Note: Sml of components may not equal total due to independent rombing. 


\section{TABLE 2}

FEDERAL PETROLEUM USAGE IN FY 1994

(in Thousands of Gallons, Billions of Britich Thermal Units, and Petajoules [Jotle $\times 10^{15}$ )

Lhit Total
(K Ga1)

Buildings 5 Facilities

Fuel oll

LPO/Propane

Energy Intensive Ops.

Fuel oil

LPG/Propane

Vehicled * Ëgipment

\section{Mator Gas}

Dist-Diesel t Pecrol.

jot Fuel

Navy Speciol

LFG/Fropane

other

Toka1
BETu*

415, 063.8

$48,540.8$

983.8

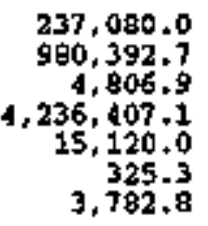

237.080 .0

$4,806.9$

$5,120+0$

325.3
782.8

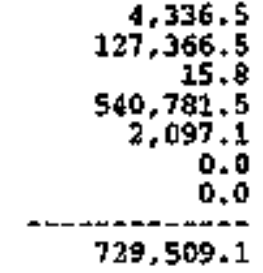

, 604.1

2.128 .5
72,2

$6,732.6$

0.10

Baru*

$9,333.7$
$1,050.5$

94,0

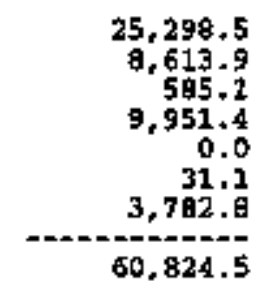

298.5

513.2

951.4

31.1

60.824 .5

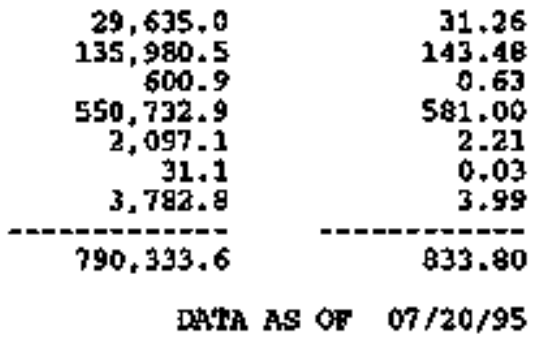

Uses a conwersion factor of:

95,500 BTUsigallon tor LPGipropane

138,700 B'TU/gallon for fuel oil, distillate-diesel \& peroleum, and navy special

125,000 BTU:igallon for motor gasoline and avtation gascine

130,000 BTUs/galiom for jet fuel

947.9 Billion BTUsPotajoule

Note: FX 1994 conitgins estimated data fior the following agencies: Departments of the Treasury, Federal Trade Commisslou, and Ofice of Personnel Mamagement. Sum of components may not equil total due to inifepentent rombing.

Source: Federal Agency Amuval Enexgy Mamagement Data Reponts 


\section{Federal Coordingtion}

A number of Federal coordination activities were carried out in FY 1994. A meeting of the Federal Interagency Energy Policy Committee ("656" Committee) took place on October 20, 1993. The meeting was attended by the Secretary of Energy, Hazel O'Leary, and the Deputy Secretary of Energy, Bill White, as well as Congressman Philip R. Sharp, Chairman of the Energy and Power Subcommittee of the House Energy and Commerce Committee, and representatives from the Federal agencies. Secretary O'Leary sounded the Clinton Administration theme of saving money by conserving resources. Congressman Sharp stressed the importance of elevating the Federal Government as a model to demonstrate what can be accompiished in the area of energy efficiency. He noted the importance of having champions for the cause of energy efficiency throughout the Government. Deputy Secretary White challenged the Committee to develop budget strategies that establish incentives for capital expenditures whitch generate savings in out-years, and to adopt the total quality management principle of measuring the progress made toward achieving clearly stated goals. Other speakers included representatives from a state energy office, an energy service company, the Office of Management and Budget, and a utility company.

The Interagency Energy Management Task Force was established by Section 547(a) of NECPA, as amended, 42 U.S.C. \& 8257. The Task Force met eight times during FY 1994. The Task Force met on December 15, 1993 to discuss agency activities and new initiztives, share information for program support, and agree on follow-up actions from the October meeting of the Federal Interagency Energy Policy Committee meeting. Among the topics discussed at the meeting were training, the SAVEnergy Program, guidance for the Federal Energy Efficiency Fund, the development of fenestration rating standards, energy savings performance contracting, the 1994 Federal Energy and Water Management Awards, utility incentives, and the possibility of a new Executive Order on energy management.

On February 23rd members of the Task Force convened primarily to discuss the pending Executive Order on energy efficiency and water conservation at Federal facilities. Representatives from the White House Office on Environmental Policy presented highlights of the proposed Executive Order and outlined several goals that would sarpass those established by the Energy Policy Act of 1992.

Task Force meetings were held on March 16th and April 20th to review the provisions of Executive Order 12902, Energy Efficiency and Water Conservation at Federal Facilities. Task Force members examined its requirements and established the following working groups to meet periodically and examine issues more closely:

- Energy Savings Performance Contracting.

- Training,

- Retention of Savings,

- Energy Audits,

- Energy Surveys,

- Water Conservation.

- Life-cycle Costing in Leased Facilities,

- Industrial Energy, 
- Quality Metrics/Measurement,

- 10-year Payback Plan,

- Awareness and Awards,

- Solar and Renewable Energy,

- New Space, and

- Alternative Foels.

A second meeting of the Federal Interagency Energy Policy Committee was convened by Ms. Christine Ervin, Assistant Secretary of Energy for Energy Efficiency and Renewable Energy and Chair of the "656" Commiltee, on April 16, 1994. The purpose of the meeting was to provide Committee members with an overview of what the different agencies were doing to address the new requirements established in Executive Order 12902. Mr. Mark Ginsberg, Chaiman of the Federal Interagency Energy Managenent Task Force moderated a discussion of four topics related to implementing Executive Order 12902. The topics of high priority for Federal agencies were agency prioritization surveys, project implementation, showcase demonstrations, and innovative financing.

The Task Force met on June 8th, August 10th, August 24th, and September 27th, 1994 to discuss progress toward Execative Order 12902 goals made by the individual working groups and to identify barriers to the implementation of the Executive Order. Central to these discussions of barriers was the work done by each of the working groups to specify the barrier and to develop strategies for reducing or eliminating the barriers.

\section{Personnel and Energy Awarepess Actfivities}

\section{Training}

During FY 1994, DOE's Federal Energy Management Program (FEMP) conducted 61 training workshops and symposia for 1,954 attendees in the efficient use and conservation of energy, water, and renewable energy in Federal facilities.

The Federal Energy Management course provided guidance on meeting the qualifications of "trained energy manager" as defined by EPACT. Nine workshops were conducted for over 195 participants nationwide. In addition, the Water Resource Management course presented instruction to help Pederal facility managers improve the efficiency of water use, consistent with legal and environmental requirements. Three workshops were conducted for 98 participants at sites across the country.

The Designing Low Energy Buildings (Non-Residential) course, formerly named Passive Solar Design Strategies, was presented 3 times for 120 participants, in conjunction with major industry conferences. The "Residential" version of the course was presented 3 times at requesting agencies' sites for 91 attendees. The one-day conses inclode analyses and case studies of building design using passive solar heating, natural ventilation and cooling, and daylighting, as well as glazing and overhangs.

The Federal Relighting Initiative (FRD) course was conduxted 5 times for a total of 178 participants. The objective was to provide guidance on energy-efficient lighting consistent with 
other facility lighting considerations, quality and cost, and whole building analysis. Topics include: basic lighting concepts; a comprehensive process for Federal relighting project development and implementation; application of the Federal Lighting Expert (FLEX) System and other analytical software tools; and the use of protessional lighing design services. During the first day of this training course, participants received lighting efficlency training, and the second day consisted of an overview on implementing Federal relighting projects. A thiri halfday provided hands-on training in the use of Federal Lighting Energy Expert (FLEX) software tool.

Nine Federal Energy Decision Screening (FEDS) workshops were held during FY 1994 for 330 attendees. This is a training course for Federal facility managers on whole-site analysis of energy conservation technical and financial opportunities utilizing the FEDS-Level I project sckeening software and the FEDS-Level 2 project implementation software.

FEMP, in conjunction with the National Institute of Standards and Technology, condacted six 3 . day workshops on life-cycle costing (LCC) and building retrofit simulation for 172 students. The first 2 days of each workshop provided hands-on training in LCC procedores that Federal agencies are required to use in evaluating energy and water conservation projects. The LCC sessions focused on technigues for selecting the most cost-effective buflding energy projects based on the present value of all energy, constuction, and maintenance costs over the life of the projects. The third day of the workshop focused on the use of the brilding retrofit analytical software called A Simplified Energy Analysis Method (ASEAM). The ASEAM-3.0 methodology was designed to assist Federal energy managers in analyzing building energy requirements and identifying and assessing the impact of various energy conservation opportunities. Federal energy managers, State and local govemment personnel, and representatives from private industry were anong the participants who received training at the workshops. An additional 5 sessions of the LCC workshop were provided for 128 students by FEMP-trained "DOE-qualified instructors."

Eight three-day courses on energy savings performance contracting (ESPC) were conducted in FY 1994 for 195 participants. In each course, facility managers, contract specialists, and building engineers were instructed on the statutory provisions for this innovative contracting/financial method, and how to identify suitable projects. ESPC allows energyefficient improvements to be installed by private contractors with no up-front capital costs. During the first two days, the course describes how to manage a raplti-disciplinary team in developing ESPC projects and to identify the engineering and contracting aspects of ESPC solicitation design and development, proposal evaluation, and contract award and implementation. The third day is for handson analysis of students' prospective projects. Among the agencies that have participated in the courses and produced project solicitations are the National Park Service in Elis Island, New York (Department of the Interior), the Forbes Field National Guard in Topeka, Kansas (Departroent of Defense), and the Department of Veterans Affairs Medical Center in Washington, D.C. Each of these facilities has issued a CBD notice.

FEMP introduced its new Water Resource Mantagement course with 2 workshops for 61 attendees in FY 1994. The course is designed to assist Federal site managers and agencies in meeting the water conservation requirements of EPACT and Executive Order 12902. 
During FY 1994, FEMP organized and participated in seven panel discussions on Federal energy efficiency, water conservation, and renewable energy topics at the Association of Energy Engineer's annual conferences around the country. Four FEMP symposia at industry conferences attracted 386 attendees.

The Federal Energy Management Program introduced its new Training Course Locator System last year to assist Federal agencies in training energy managers and in meeting the requirements of the EPACT. The Locator System connects those seeking particular training courses with the sponsoring organization for those courses by responding to numerous requests from Federal energy managers and coordinators, utlity managers, engineers, building operators, and facility personnel.

During FY 1994, the locator System received 150 course descriptions from sponsors and maintained an undated schedule of courses being offered to improve energy savings and conserve water. The Training Locator System includes course sponsors from the private and public sector. Course sponsors include the U.S. Department of Energy, the National Renewable Energy Laboratory, Johnson Controls, Inc., the Association of Power Administration, the Lighting Design Lab, the U.S. Army Corps of Engineers, the University of Wisconsin, North Carolina State, and Texas A\&M.

EPACT reguires GSA to hold five workshops per year to promote coordinated energy management strategies with Federal, State, Jocal, tribal, and county public officials. In 1994, the workshops were held in Atlanta, GA, Kansas City, MO, Tysons Comer, VA, San Francisco, CA, Seattle, WA, Austin, TX, Denver, CO. Topics covered included demand side management, building life cycle costing, train-the-tratner, and current energy issues.

FEMP, DOE's Kansas City Support Office, NIST, and GSA jointly developed a "train-the trainer" program for the Building Life Cycle Costing (BLCC) class. Through this progran, 16 instructors were qualified to teach the academia, state governments, and the Federal government. Through this process, the BLCC class is now widely offered throughout the U.S.

\section{Recognition}

Outstanding accomplishments in energy efficiency and water conservation in the Federal Sector were recognized with the presentation of Federal Energy and Water Management Awards on October 6, 1994 at the Dirksen Senate Office Building in Washington, D.C. The Federal Energy Efficiency, Renewables and Water Conservation Awards are sponsored by the Federal Interagency Energy Policy Committee ("656" Committee) and the Department of Energy. Awardees were selected from outstanding Federal energy managers and contributors who:

- Improved energy performance, through increased energy efficiency, use of renewables and water conservation.

- Implemented proven energy efficiency measures; energy and water conservation techniques, devices, equipment, or procedures; and renewable energy projects.

- Developed and implemented training programs for facility energy and water managers, operators, and maintenance personnel.

- Developed and implemented employee awareness programs. 
- Succeeded in generating utility incentives, or energy savings performance contracts, and other Federally approved performance based energy and water savings contracts.

- Made successfal efforts to fulfill compliance with energy and water reduction mandates.

Special emphasis categories in 1994 included mobility energy efficiency and sastained exemplary service. Mobility energy involves the efficient ose of entergy for aircraft, ship, and off-highway vehicles. Sustained exemplary service involves exceptional service over a number of years in creating and instionting increased use of renewable energy, water and energy conservation programs, projects, or technologies.

Recipients of this year's awards were selected from 125 nominees submitted by 13 Federal agencies. Forty individoals and members of small groups received cash awards totalling $\$ 156,000$. The cash awards ranged from $\$ 2,000$ to $\$ 10,000$ each. Dhstribution of awards among the Federal agencies for accomplishments in FY 1993 is indicated below. Awards were presented in the following categories:

\begin{tabular}{||c|c|c|c|c|c|c|c||}
\hline Agency & $\begin{array}{c}\text { Sustained } \\
\text { ServicerEnergy }\end{array}$ & $\begin{array}{c}\text { Sustained } \\
\text { Service/Water }\end{array}$ & Mobility & Individual & Organization & $\begin{array}{c}\text { Small } \\
\text { Groug }\end{array}$ & $\begin{array}{c}\text { Water } \\
\text { Conservation }\end{array}$ \\
\hline DaD & 1 & & & & & & \\
\hline DOE & 1 & & & 5 & 2 & 1 & 1 \\
\hline DOI & 1 & & & & & & \\
\hline DOL & 1 & & & & & & \\
\hline GSA & & & & 4 & 3 & 4 & \\
\hline HHS & & & & 1 & 1 & & \\
\hline NASA & & & & 1 & 2 & & 1 \\
\hline USDA & & 1 & & & & & \\
\hline USPS & 1 & & & 1 & & & \\
\hline Air Force & & & & 1 & & & \\
\hline Army & & & & 4 & 5 & 1 & 1 \\
\hline Navy & & & 3 & & 2 & & \\
\hline Treasury & & & & & & 1 & \\
\hline & & & & & & & \\
\hline TOTALS & 5 & 1 & 3 & 17 & 15 & 7 & 3 \\
\hline
\end{tabular}




\section{Energy Awareness}

The Federal Government, as the largest single employer in the United States, has the responsibility to set an example for the nation by conducting energy awareness programs. Most agencies have ridesharing, carpoling, andor public transportation programs in effect. Many agencies also participate in recycling programs. Examples of employee awareness activities at the agencies follow.

The Department of Agriculture has included in its implementation strategy initiatives to institute and/or emphasize energy conservation awareness with facility managers and building occupants and to provide incentive awards to facility managers and others who contribute to the energy efficiency of the Department.

The Department of Commerce included in its revised Deparment Administrative Order on Federat Energy Management, a strategy to promote energy and water conservation through employee training, awareness, and outreach programs.

At the Department of Health and Human Services, the Social Security Administration Headguarters Complex has an employee energy efficiency campaign underway which includes articles in a monthly bulletin to explain its energy conservation strategies and examples of how employees can participate.

The Department of Housing and Uban Development encourages employees to participate in its rideshare assistance program through promotional flyers and displays. The Department has also implemented a nationwide transit subsidy program to encourage the use of mass transportation.

At the Department of the Interior, Departmental Energy Conservation Committee meetings allowed for dissemination of information and emphasis on increased management awareness of the energy management program. The bureaus were reintroduced to conputer programs, training courses, and reading materials available on energy management. Through an ongoing energy-notice program beilding occupants received written notification through random surveys and scheduled inspections when energy-consoming equipment such as lights, radios, and fans have not been tumed off. Energy awareness discussions have been held during lunch time. The Department of Interior also has a computerized rideshare program and bureaus in some areas have provided free parking incentives for car-pooling and ridesharing.

The Department of Labor's Fuel Efficiency Outreach Program includes nidesharing activities and employee awareness programs sponsoned by the General Services Administration, local goveraments, and transit authorities.

The Department of State has an active agency-wide employee education program which promotes the idea that conservation of energy in buildings, facilities, vehicles and equipment is the responsibility of each and every employee.

The Department of Transportation distributes information on new procedures, products, and contracting methods that will facilitate more efficient operation of facilities throagh its 
Departmental Energy and Water Management Committee. The Department also has an ongoing ridesharing program and an active transit benefit program.

Employee awareness plays an integral part of the Treasury Department's energy management program. The Department and individual bureaus seek to make employees aware of the positive aspects of energy conservation. For example, the Birmingham Financial Center has a continsing edncation progran for its employees; the Intemal Revenue Service educates employees about ridesharing and energy conservation; and the Secret Service uses posters to educate its employees and public transportation incentives to encourage the use of mass transit. Locally, in Washington, D.C., most Treasury bureaus offer public transportation incentive programs; among them Departmental Offices and the Internal Revenue Service. The IRS ts also closer to implementing a national Flexiplace Program designed to reduce fuel energy consumption and air pollution by allowing employees to work at home or at a satellite office, rather than commuting long distances to work. Presently, it is in a "pilot stage" in the Seattle District Office of the IRS.

The Eavironmental Protection Agency's energy and water conservation grogram includes the Conservation Information Clearinghouse and Hotline, a newsletter, an Awareness Materials Package for energy managers, a summary document on energy efficient and water conserving technologies for facility managers, program and technology briefings.

The Federal Emergency Management Agency, National Emergency Trainìg Center distributed an Energy Gram newsletter that lists energy conservation suggestions.

The General Services Administration included as one point in its Seven Point Energy and Water Reduction Plan issued in 1993, employee and tenant conservation awareness. GSA is the lead agency in the Federal Ridesharing Program and has recently taken the lead in implententing the Federal Employees Clean Air Incentives Act which authorizes agencies to provide transit subsidies to Federal employees.

Field installations at the National Aeronautics and Space Administration have implemented various outreach prograns to redece the use of vehicle petroteum foets by agency and contractor employees. Ridesharing and use of public transportation is emphasized.

The Naclaar Regulatory Commission, has an ongoing employee awareness program at its One and Two white Flint North Buildings which provides information to employees regarding their responsibilities and contributions in achieving emergy reduction gaals. NRC participates in a ridesharing network; offers public transportation subsidies to all employees; uses non-monetary incentives such as flextime, compressed work schedules and priority parking assignments for car and van pools; and provides facilities for bicyclists, including locker rooms and showers. NRC aIso promotes reduction in fuel consumption through transportation fairs, employee announcernents, and newsletters.

The Panama Canal Commission (PCC) furnishes agency-wide directives and pints articles in Engiish and Spanish in its official bimonthly publication (The Spillway) as a means of disseminating energy-related concerns to its employees. Canal area U.S. Military components also publish a weekly newspaper and operate an English language TV station accessible to 
PCC, which actively carries relevant energy saving and conservation objectives, tips and other energy nse issnes. The PCC Incentive Awards Suggestion Program further stimulates employee energy conservation awareness and participation.

Employee awareness and recognition programs at the U.S. Postal Service also included mailing of the DOE "Energy Awareness" poster to all 37,000 postil facilities and publication of notices for a "Turn Off the Lights Campaign". The Postal Service continues its ridesharing program which includes transit subsidies, preferential parking, a newsletter, educational activities, flexible work hours, and recognition awards. The Postal Service began an initiative in FY 1994 to educate purchasing personnel on issues such as energy conservation and sources of supply for energy efficient products. In addition to briefings and training, a quarterly newspaper was published for purchasing personnel covering energy and environmental issues.

The Tennessee Valley Authority's Facilities Services Energy Reduction Team implemented an employee energy awareness campaign during FY 1994. The team displayed monthly energy use posters and periodic post-it notes to remind employees to turn off unnecessary equipment. TVA is also working to combine its energy awareness progran with its solid waste minimization program.

The Department of Energy, the Office of Personnel Management, and the Railroad Retirenent Board offer employee energy awareness programs.

Energy Awareness Month, celebrated in October 1994, promoted energy awareness with the theme "Energy - Our Futare is Today!". DOE designed and distributed posters and a carneraready logo for use in publications. 


\section{E. Funding for Energy Efficiency in Buildings and Facilities}

The National Energy Conservation Policy Act requires each agency, in support of the President's annual budget request to Congress, to specifically set forth and identify funds requested for energy conservation measures. Table 3 presents total agency funding reported from FY 1985 through FY 1994 for energy conservation retroftts and capital equipment. Funding for energy conservation declined from $\$ 258.6$ million in FY 1985 to a low of $\$ 52.2$ million in FY 1989. Reports from Federal agencies indicated that $\$ 120.9$ million was spent in FY 1993 on retrofit expenditures and $\$ 230.2$ million in FY 1994, with FY 1995 funding projected to be $\$ 354.2$ million. In some cases, the data provided by the agencies includes funding from operation and maintenance accounts that was specifically identified as contributing to energy efficiency. Figure 3 illustrates agency spending trends for the five largest energy consuming agencies and other Federal agencies.

Table 3

Agency Expenditures for Energy Conservation Retrofits and Capital Equipment, FY 1985 throught FY 1994 (Thousgnds of Nominal Dollars)

\begin{tabular}{|c|c|c|c|c|c|c|c|c|c|c|c|}
\hline & & & & & & & & & & & Projected \\
\hline & 1985 & 1986 & 1987 & 1988 & 1989 & $19 \%$ & 1991 & 1992. & 1993 & 1994 & \\
\hline$O C$ & N/A & N/A & N/A & $\mathrm{N} / \mathrm{A}$ & N/A & N/A & N/A & 872 & $N / A$ & 51 & N/A \\
\hline OE & $14 \$ 00$ & 14,500 & 16,500 & 18,900 & $19 A 00$ & 19,500 & 20,400 & 20,650 & 20950 & 24,850 & \$O,A00 \\
\hline OI & 198 & 5,535 & 0 & 0 & 4,338 & 0 & 1,272 & 9,800 & 4,859 & 1,662 & 605 \\
\hline 0 & 0 & 0 & 0 & 195 & 484 & 6,100 & 26,400 & 0 & N/A & 1,284 & 1,500 \\
\hline D. & 238 & 31 & 106 & 142 & $\$ 84$ & 57 & 35 & 16 & 0 & 0 & 0 \\
\hline$\sigma \mathrm{T}$ & 13,650 & 15,000 & 12,104 & 12,700 & 2,908 & 0 & 460 & 143 & 593 & 5,970 & 3,678 \\
\hline A & NA & N/A & $\mathrm{N} / \mathrm{A}$ & $N / A$ & N/A & N/A & $N / A$ & $N / A$ & 500 & N/A & N/A \\
\hline SA & 6,700 & 6,100 & 2,900 & 9400 & 4,868 & 11,125 & $30, \mathbf{I} 23$ & 37,000 & 30,000 & 37,000 & 45,000 \\
\hline US & 0 & 0 & 0 & 423 & 427 & 427 & 427 & 0 & 1,813 & 1,915 & 2,800 \\
\hline UL & NA & N/A & N/A & $\mathrm{N} / \mathrm{A}$ & $\mathrm{N} / \mathrm{A}$ & $N_{A}$ & $\mathrm{~N} / \mathrm{A}$ & $N / A$ & 43 & 30 & 0 \\
\hline ASA & 11,800 & 12,100 & 1,700 & 1,400 & 4,499 & 2943 & 7,7556 & 7,086 & 25,072 & 24,658 & 16,617 \\
\hline CC & 1,274 & 73 & 1,174 & 600 & 378 & 361 & 807 & 249 & 500 & 608 & 140 \\
\hline & N/A & N/A & $\mathrm{N} / \mathrm{A}$ & $N / A$ & N/A & $\mathrm{N} / \mathrm{A}$ & $N / A$ & $\mathrm{~N} / \mathrm{A}$ & 16 & 13 & 12 \\
\hline ATE & N/A & N/A & $N / A$ & N/A & $\mathrm{N} / \mathrm{A}$ & $N / A$ & $N / A$ & $N / A$ & N/A & 67 & 100 \\
\hline SY & 0 & 0 & 2,977 & 2,393 & 2,823 & 1,134 & 836 & NA & 1,344 & 4,826 & 4,707 \\
\hline A & N/A & N/A & N/A & N/A & N/A & $N_{A}$ & $\mathrm{~N} / \mathrm{A}$ & NA & 475 & 844 & 929 \\
\hline & 2,500 & 0 & 0 & 500 & 300 & 1,547 & 1,752 & 7,300 & 7045 & 7,277 & 4,780 \\
\hline & 55,300 & 9,300 & 5,100 & 3,800 & 4,010 & 4,000 & 4,000 & 2,293 & 1,116 & $1, \pm 23$ & 10,000 \\
\hline & 13,000 & 11,500 & 500 & 9,860 & 5,500 & 11,209 & 9,970 & $10 ; 000$ & 12,100 & 9,050 & 11,960 \\
\hline & & 4,139 & 1,011 & 5,597 & 22,209 & 59,374 & 14,038 &, 018 & 20,870 & 230,228 & 354,228 \\
\hline
\end{tabular}

Note: Bold indjeates top five energy users in buildings and facilities. DOE expenditures abo inclode fuads for exabgy susvoys. Does not include energy srvings performence contracts and utility demeod side management incentives.

Sontre: Federal Agency Antual Eotrgy Managemebe Data Reports

The Defense Department identified $\$ 109.0$ million in expenditures for energy efficiency projects in FY 1994. This amount includes $\$ 50.0$ million in appropriated Energy Conservation Investment Program funds and $\$ 59.0$ million from operations and maintenance acconnts. Additional funds were expended by DoD to support energy efficiency, but no reporting system exists to track these additional expendinures. DoD projects expenditures of $\$ 221.0$ million for energy efficiency projects in FY 1995. 
FIGURE 3

ENERGY CONSERVATION RETROFIT EXPENDITURES

(Nominal Dolkars)

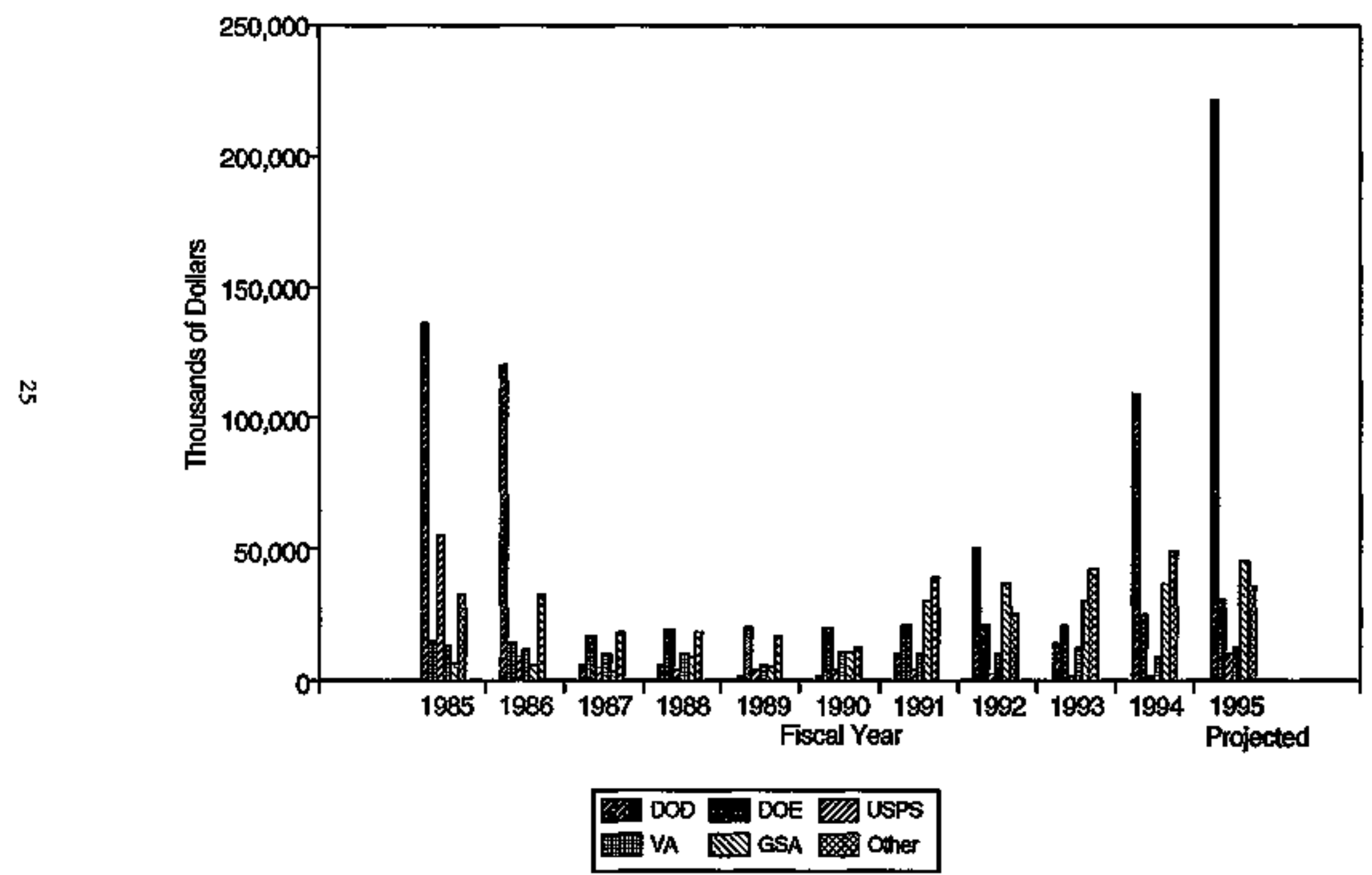

Source: Federal Agency Anmual Energy Management Data Reports 
The General Services Administration spent \$37 million in FY 1994 on 235 energy efficiency projects. Althongh there were additional projects with energy savings, these conponents were not tracked separately. GSA plans expenditures of \$45 million in FY 1995 for energy efficiency.

At DOE, funding for energy surveys in boildings and processes amounted to $\$ 6.3$ million in FY 1994. DOE invested $\$ 18.6$ million on 82 retrofit projects in building and metered process facilities. These projects included the installation of energy monitoring and control systems; modification of HVAC systems, mechanical equipment, and boiles; improvements in lighting and electrical power systems; and the addition of building insulation and storm windows. The anticipated savings from these retrofit projects in FY 1994 is 780 billion Btu. The projected level of funding for retrofits for FY 1995 is approximately $\$ 30.4$ million.

\section{Federal Energy Eficiency Fund}

The Fedieral Energy Efficiency Fund was established by section 546(b) of NECPA, as amended by EPACT, to provide grants to agencies to assist them in meeting the mandated energy efficiency and water conservation requirements. The legislation anticipated that these funds would enhance and stimulate other funding sources, such as agency appropriations, utility demand side management investments, and energy savings performance contacts.

During FY 1993, DOE developed guidelines to be followed by agencies for submitting proposals for grants fronn the Fund. The "Oiuidelines for Proposals for Federal Energy Efficiency Fund Support" were signed into effect on December 29, 1993. A supplement to the Guidelines, "Special Clarifications for Life Cycle Cost Inputs," was issued to the agencies on February 11, 1994. The Special Clarifications provide detailed information on the accounting, application of life cycle costing techniques, and special calculations to be nsed in submitting proposals.

Initial proposals were received in March 1994. In total, 42 proposals were received from March through September of FY 1994. These proposals requested over \$10.5 million in grants from the Fund. Twenty-three of these proposals were selected for grant funding and received commitments equal to the \$6 million available in FY 1994 fornds.

As the number of proposals increased, the limited funding was directed to those proposals which were most competitive considering the four factors listed below:

(A) The cost-effectiveness of the project. (such as the savings-to-investment ratio)

(B) The amount of energy and cost savings anticipated to the Federal Government.

(C) The amount of funding committed to the project by the agency requesting financial assistance.

(D) The extent that a proposal leverages financing from other non-Federal sources.

In some cases, proposals were rejected due to minimal cost-effectiveness of the project. In many cases, agencies were advised that there was insufficient funds available to provide grants for their otherwise worthy proposals and that the proposals would be funded in FY 1995 as appropriations were made available. 
Overall, the funded projects that were submitted in FY 1994 will leverage an additional $\$ 2.5$ million in agency and non-Federal funding. The combined investment from the Fund and other sources will generate over $\$ 21$ million in energy and water cost savings in future beudget years.

Both the amount of non-Federal investment and the savings to the taxpayer are expected to increase as future proposals are submitted to the Fund seeking grants to put Energy Savings Performance Contracts in place. In FY 1994, discussions were held with several agencies on the preparation and submission of such proposals in FY 1995. At least seven agencies are expected to submit one or more such proposals in FY 1995.

Examples of some of the first project funded are described below.

Dangling Rope Marina Project, National Park Service, Department of the Interior This project will fund the installation of photovoltaics at the National Park Service marina on Lake Powell at Dangling Rope, Utah. The project will combine $\$ 350,000$ from the Federal Energy Efficiency Fund with $\$ 438,500$ in non-Federal funds contributed by the state, the utility, and the park vendor, along with $\$ 404,500$ in Park Service and other Federal funding. Besides the 59 percent improvement in energy efficiency and the cost savings of $\$ 270,149$ (net after investment), the project offers environmental benefits which reinforce its value. Chief among these is the reduced use of diesel fuel which is barged into the marina to power the generators. In addition to a reduction of exhaust gases which can accumulate at lake level during certain weather conditions, several ninor fuel spills have occurred in the past, and a recent mishap nearly resulted in the diesel tanker sinking in the lake. The cost of cleaning such an oil spill has been estimated at over $\$ 1$ million.

Kennedy Space Center Projech, National Aeronautics and Space Administration The NASA Kennedy Space Center project includes the relighting of office spaces, hangar bays, and laboratories. It also includes heating, ventilating, and air conditioning (HVAC) duct modiffcations and the installation of heat pipes into the HVAC system to passively recover energy used in air conditioning the building. The grant request was for $\$ 88,900$ and the project is also expected to qualify for an $\$ 11,000$ rebate from the local utility. The project will save nearly $\$ 370,000$.

The Yellowstone National Park Project, National Park Service, Department of the Interior The first of two projects at Yellowstone National Park will improve the energy efficiency of several of the widely-dispersed facilities at the Park, saving well over 100 billion Btu, and will result in over $\$ 600,000$ in savings to the taxpayer. The projects include simple retrofits such as insulating walls and ceilings and replacing windows and doors with more efficient products, as well as more complicated projects such as replacing a diesel generator with a more efficient generator and battery storage system. Also irxluded will be modifications to district heating systems and propane storage systems to improve efficiency. Lighting reirofits will be implemented in a variety of buildings. Private project funding of approximately $\$ 70,000$ will be provided by the Yellowstone Institute.

The second project, furded under a separate grant, will irnprove bulling insulation, reduce ceiling height to reduce the volume of conditioned space, replace incandescent lighting with 
flworescent lighting, and replace an oil heating system with a high efficiency gas system. The modifications will improve energy efficiency by more than 60 percent and save over $\$ 300,000$.

Northwest Fisheries Science Center, National Oceanic and Amospheric Administration, Deparment of Commerce

The first water conservation project to be funded by the Federal Energy Efficiency Fund will recycle water that is currently passed once through fish culture tanks at the Center and drained to the waste water system. Approximately 218 million cubic feet per year of water will be saved or approximately 90 percent of the water used at the Center. As one of the largest water users in the City of Seattle, the reduction will make a measurable difference in the water demand for the City. For that reason, the City is providing $\$ 216,173$ in funding for the project The Federal Energy Efficiency Fund will provide $\$ 471,399$ and the remaining $\$ 173,654$ will come from the Department of Conmerce. The project will save over $\$ 2.3$ million and will have a simple payback period of 5 years.

\section{Energy Savings Performance Contracting}

Section 155 of EPACT amended Title VIII of NECPA, sections 801 to 804 , relating to shared energy savings contracts. Section 801 , as amended, gives agencies the authority to enter into energy satings perfomance (ESP) contracts and describes the methodology of contract implementation. Energy savings perfomance contracts are designed to reduce the cost of energy in Federal buildings without capital investment by the building owner. Typically, the terms of such a contract provide for contractor purchase, installation, and maintenance of energy conservation measures with a guarantee of annual energy cost savings in consideration for a share of such savings. Under these conitacts, the contractor is expected to bear the risk of performance, make a significant initial capital investrnent, guarantee significant energy savings to the government agency, and from these savings, the agency, in effect, makes payment to the contractor.

Section 801 requires DOE to issue approppriate rules containing: (1) methods and procedures for selecting, monitoning, and terminating energy savings perfomance contracts; and (2) "substitute regulations" for provisions of the Federal Acquisition Regulation (FAR) which are inconsistent with the intent of section 801 as amended and which may be revised consistent with generally applicable procurement statutes.

On April 11, 1994, DOE published a notice of proposed rulemaking under section 155 of EPACT. DOE held a public hearing on June 1, 1994, and the closing date for receipt of written comments was Jone 10, 1994. Nineteen interested persons filed written comments of which 13 presented oral comments at the public hearing. A notice of final rulemaking was published on April 10, 1995. DOE fully considered all of the suggestions and arguments made in the comments in revising the proposed regulations and the draft model solicitations developed by DOE. The model solicitations provide uniform formats and standardized contract provisions recommended for Federal agency use in energy savings performance contracts. The model solicitations include some provisions that have been determined necessary to accommodate the unique nature of energy conservation services which often require third-party financing. 
The Act requires that DOE obtain the concurrence of the Federal Acquisition Regulatory Council in the issuance of the final nule. The final nule is expected to be issued in mid-FY 1995.

Intitiatives taken by Federal agencies to actively pursue energy savings performance contracts produced three ESP contract awards in FY 1994, bringing the total namber of awarded ESP contracts to 19. ESP contracts awarded during FY 1994 are briefly described below. Through FY 1994, the total contractor investment in Federal ESP contract projects was approximately $\$ 39.8$ million. The Government share of the projected savings over the lives of these projects is approximately $\$ 44.5$ million. The chart on the next page lists all ESP contracts awarded through FY 1994, providing project descriptions and the dollar amounts for contractor investment and Govermment share of savings for each contract.

On January 31, 1994 the U.S. Army awarded a contract at Fort Polk, Louisiana to install closed loop ground source heat pumps at 4,003 family housing units. The contractor will also concurrently insulate attics, add weather stripping and caulking, install low-flow shower heads and residential hot water desuperheaters, insulate water heaters, and retrofit interior and exterior lighting. The contract term is for 20 years with a contractor capitol investment of $\$ 18$ million. The Amy's projected share of savings is almost $\$ 10$ million (22 percent) with the contractor's share of savings projected at $\$ 34$ million (78 percent).

The U.S. Air Force awarded two ESP contracts in FY 1994. The Eirst phase of an ESPC project at Randolph Air Force Base, Texas has been completed. Awarded in February 1994, it involves relamping several large facilities with options to add other facilities. The first phase included changing out over 15,000 old, inefficient, fluorescent and incandescent light fixtures for a savings of 4.5 million kilowatt hours, netting over $\$ 239,000$ in energy savings. Phase II provides for follow-on negotiations of other electrical savings initiatives. Randolph's energy manager has already identified over 11,000 fixtures to replace in phase two. Initial estimates indicate saving of 3.4 million kilowatt hours and $\$ 170,000$.

An ESP contract was awarded at Hill Air Force Base, Utah in early July 1994. This is a basewide ESP contract with supplemental funding from the local utility company. Estimated savings are 44,200 MWH ( $\$ 1.5$ million) over a 5 year period and should reduce the base's peak loœd by 18 percent.

Agencies have reported that ESP contracting is a difficult procedure, which must be executed under Federal Acquisition Regulations,(FAR) that are procedurally complex, extremely timeconsuming, and therefore burdensome for small and mid-sized energy service companies typically interested in ESP contract business. In addition, many procurement officials are unfamiliar with ESP contract conditions under the FAR. Because ESP contracts are a relatively new option, there ane many concerns as to what is appropriate under FAR and how to evaluate and award contracts. 


\begin{tabular}{|c|c|c|c|}
\hline 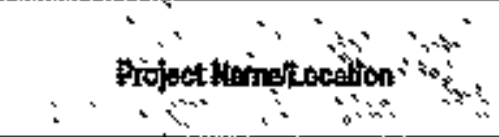 & 3 & 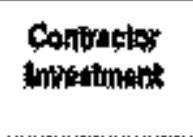 & 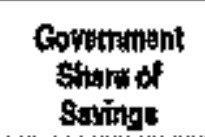 \\
\hline $\begin{array}{l}\text { DOE Lawence Berkeloy Lab } \\
\text { Bexteley, CA }\end{array}$ & 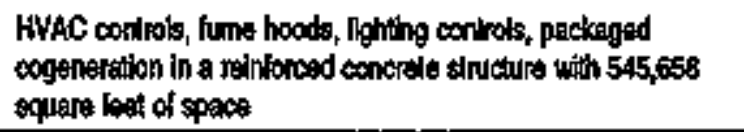 & $\$ \$ 28,000$ & $\begin{array}{l}\text { S150,000 } \\
\text { over } 10 \text { yeats }\end{array}$ \\
\hline 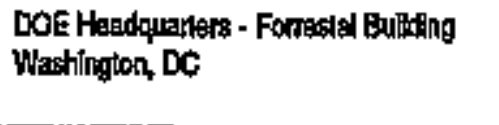 & 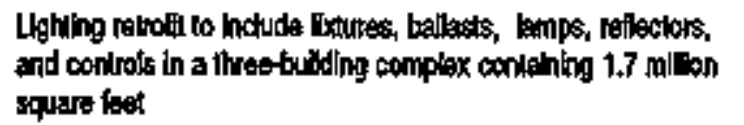 & $\$ 1,372,000$ & $\begin{array}{c}\$ 1,072,559 \text { over } \\
7 \text { years }\end{array}$ \\
\hline 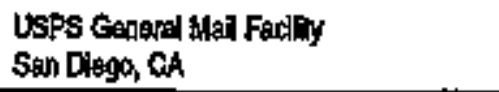 & 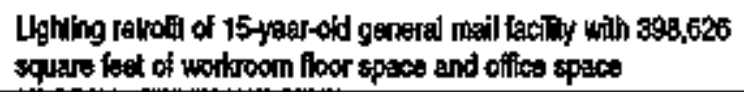 & $\$ 104,714$ & $\begin{array}{l}\$ 590,390 \\
\text { over } 7 \text { yoars }\end{array}$ \\
\hline 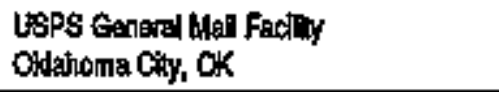 & 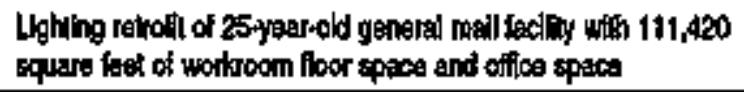 & $\$ 265,091$ & $\begin{array}{l}\$ 31,630 \\
\text { over } 5 \text { years }\end{array}$ \\
\hline 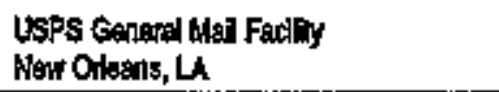 & 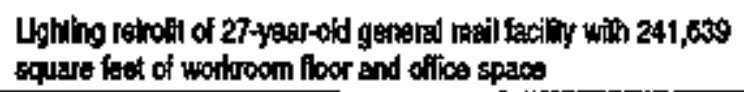 & $\$ \$ 007,005$ & $\begin{array}{l}\$ 96,150 \\
\text { over } 5 \text { yas }\end{array}$ \\
\hline 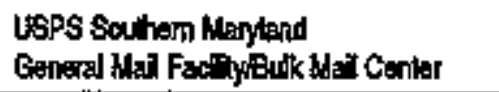 & 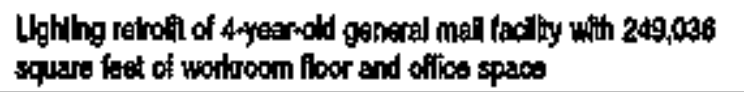 & 3837,028 & $\begin{array}{l}57,065 \\
\text { over } 5 \text { years }\end{array}$ \\
\hline $\begin{array}{l}\text { Randolph At Fores Esse } \\
\text { Sen Antonio, TX }\end{array}$ & 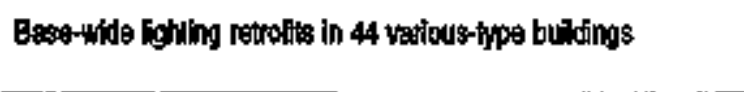 & 5767,200 & $\begin{array}{l}5175,120 \\
\text { ower } 7 \text { yogis }\end{array}$ \\
\hline Hill Air Forcs Basa, Whah & Baseridde retrolites & TED & TEO \\
\hline $\begin{array}{l}\text { Copus Christ Anmy Depst } \\
\text { Corpus Christit, TX }\end{array}$ & 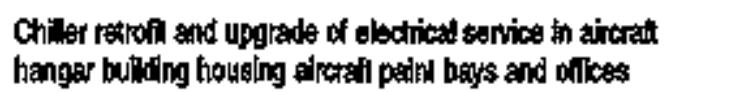 & $\$ 755,850$ & $\begin{array}{l}\text { \$,460,791 uret } \\
25 \text { yearg }\end{array}$ \\
\hline $\begin{array}{l}\text { Alamenu Amoy Fambly Housing } \\
\text { Araa, thonolulu, } \mathrm{H}\end{array}$ & 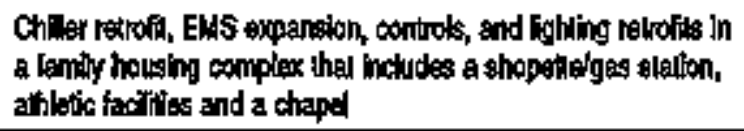 & $\$ 10,160,0 e 8$ & $\begin{array}{l}\text { st,84t,051 orat } \\
15 \text { years }\end{array}$ \\
\hline $\begin{array}{l}\text { Cas AluPropans Hbing Plarl } \\
\text { Fon Stomad, GA }\end{array}$ & Boso-wide peak shaving project for propano-sir mbing plant & 5921,570 & $\begin{array}{l}54,042,091 \text { ofer } \\
20 \text { reard }\end{array}$ \\
\hline 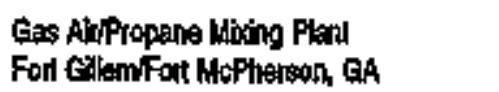 & Ease-wide peak shaving prolect for propane-air miting plant & $\$ 1,052,0 \times 0$ & $\begin{array}{l}97078 \text { ow wre } \\
20 \text { yas. }\end{array}$ \\
\hline $\begin{array}{l}\text { Any Famiy Housing Aras } \\
\text { Fort Polk, LA }\end{array}$ & 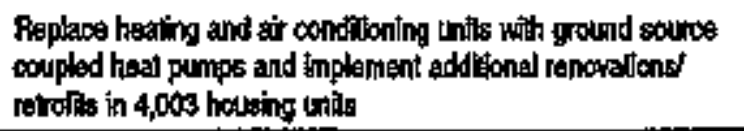 & $\$ 18,000,000$ & $\begin{array}{l}59,984,974 \text { ond } \\
20 \text { yors }\end{array}$ \\
\hline $\begin{array}{l}\text { Newy Traiting Center, Buiding } \\
\text { 3400, Greal Lakes, L }\end{array}$ & 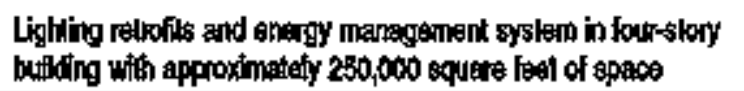 & $\$ 500,040$ & $\begin{array}{l}\$ 78,000 \\
\text { over } 10 \text { years }\end{array}$ \\
\hline $\begin{array}{l}\text { Nawd Ai Test Cenler } \\
\text { Patuxent Flver, WO }\end{array}$ & 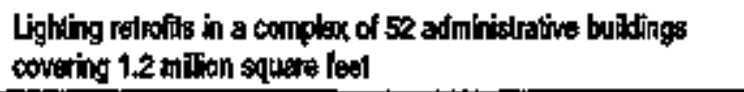 & $\$ \infty 60,000$ & $\begin{array}{l}5172,000 \\
\text { over } 10 \text { years }\end{array}$ \\
\hline $\begin{array}{l}\text { Nay San Dlego Region } \\
\text { Commissates, CA }\end{array}$ & Ulghing relsolits th one commissary & $\$ 158,434$ & $\begin{array}{c}\$ 78,205 \\
\text { cars } 10 \text { yoars }\end{array}$ \\
\hline $\begin{array}{l}\text { Nawy San Dtego Region } \\
\text { Commissevies, CA }\end{array}$ & 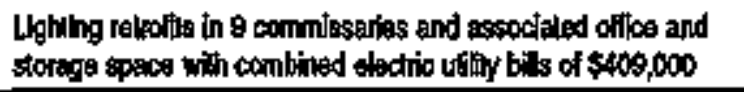 & $\$ 50,000$ & $\begin{array}{l}\$ 490,000 \\
\text { ower } 10 \text { year }\end{array}$ \\
\hline $\begin{array}{l}\text { NaSA's Wtahoud Assembly } \\
\text { Facimy, Non Orlaans, LA }\end{array}$ & 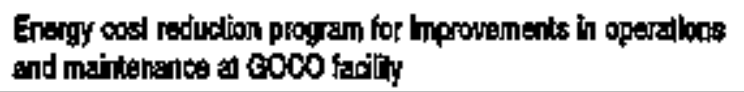 & Neglobio & 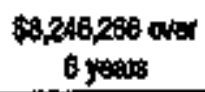 \\
\hline $\begin{array}{l}\text { Veterans Affatrs Nedital Center } \\
\text { West Haren, CT }\end{array}$ & 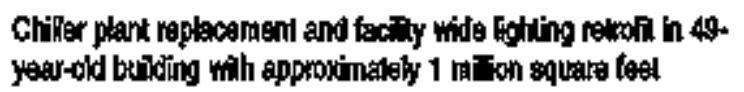 & $\$ \$, 940,000$ & $\begin{array}{l}\text { \$890,000 } \\
\text { onar } 16 \text { yos. }\end{array}$ \\
\hline
\end{tabular}




\section{Demand Side Management (DSM) Progrant Participation}

Utility-sponsored demand side management programs represent a significant source of funds to help Federal agencies finance conservation projects. In these programs, utilities pay a portion of the cost of purchasing new, more energy efficient equipment in the form of a rebate. Rebate programs promote the installation of more energy efficient measures such as lighting systems, insulation, cooling equipment, efficient motors, etc., bat require the customer, in this case the Federal Govenment, to finance a portion of the equipment cost. DSM programs provide leverage for the user's energy investment dollars and at the same time help the utility to avoid the cost of building new power plants. EPACT and the Executive Order authorities place heavy emphasis on DSM as a means for Federal agencies to achieve energy conservation requirements.

The followisg agencies reported participation in demand side management programs in FY 1994:

- Department of Agriculture

- Department of Commerce

- Department of Defense

- Department of Energy

- Department of Health and Human Services

- Department of Housing and Urban Development

- Department of the Interior

- Department of Justice

- Department of State

- Department of Transportation

- Department of the Treasury

- Department of Veterans Affairs

- General Services Administration

- National Aeronantics and Space Adrininistration

- Nuclear Regulatory Commission

- United States Postal Service

DSM activities reported by the agencies occurred at installations widely distributed across the country. This decentralization of DSM participation makes it difficult for agencies to track all DSM activities undertaken by all respective sub-agencies, bureaus, and field offices. FY 1994 DSM activities which were reported and quantified totaled approximately $\$ 7.2$ million in rebates or credits received by Federal agencies. Agencies identified estimated annual savings of 904.4 billion Bur resulding from DSM activities. These totats do not, however, reflect the total DSM benefits received by the Federal Government as a whole for FY 1994.

At the Department of Energy, DSM activities during FY 1994 saved approximately $\$ 448,300$. GSA received rebates of approximately $\$ 3.0$ million for energy conservation projects in FY 1994. Rebates are typically offered within a geographic area, and rebates received by GSA are generally retumed to the regions for ađditional energy project funding. 


\section{F. Lffe-Cycle Costing (LCC)}

Section 544 of NECPA, as amended in 1988, requitres DOE to establish practical and effective methods for estimating and comparing the life-cycle costs of operating Federal buildings, including the life-cycle energy requirements and potential savings for such buildings, and the life-cycle capital costs for energy systems of new buildings, as well as thase required for retrofit of existing stnuctanes. EPACT further amends NECPA to require, after January 1, 1994, agencies which lease buildings to fally consider the efficiency of all potential building space at the time of renewing or entering into a new lease.

On November 20, 1990, DOE issued a Notice of Final Rulemaking to amend Title 10 of the Code of Federal Regulations, Part 436, which sets forth guidelines applicable to Federal agency in-house energy management programs. The principal regulatory changes involved amending the life-cycle cost methodology and procedures to provide for an annually cetermined marketbased discount rate and for a more effective system to revise annually the energy cost escalation rates that Federal agencies are required to assume. In developing the final amendments, the Department of Energy actively consulted with the Office of Management and Butget, the Deparment of Defense, and the General Services Administration. At the beginning of FY 1994, the 1994 edition of energy prices and discount factors for life-cycle cost analysis, developed with the technical assistance of the National Institute of Standards and Techrology, was published and distributed to Federal energy managers.

\section{G. Procurement Policy}

The Federal Government is the single largest purchaser of energy-related products and the largest user of energy in the United States. There is enormous potential for energy and dollar savings through procurement policies emphasizing energy efficiency. Such policies will not only reduce energy costs in the Federal budget, but will expand the market for efficient products, create a strong "market pull" for new technologies, and set a clear example for other govermment and corporate purchasers.

Section 161 of EPACT directs the General Services Administration, the Department of Defense, and the Defense Logistics Agency (DLA) to include energy efficiency in their procurement and supply functions. The Office of Federal Procurement Policy (OFPP) within the Office of Management and Budget (OMB) develops guidance for all senior agency procurement executives to encourage the procurement and acquisition of energy efficient products.

During FY 1994, the President signed Executive Order 12902, "Energy Efficiency and Water Conservation at Federal Facilities," which both reinforces and broadens the section 161 mandate. Specifically, section 507 of the Executive Order requires all Federal agencies to buy "best practice" products, when practicable and cost-effective. Best practice products are those which are in the upper 25 percent of energy efficiency for all similar products, or products that are at least 10 percent more efficient than the minimum level that meets Federal standards.

DOE FEMP initiated a program to assist agencies in implementing the EPACT and Executive Order requirements for energy efficient procurement. The Energy-Efficiency and ResourceConservation Challenge ("Procurement Challenge") is co-sponsored by DOE, the White House 
Council on Environmental Quality and OMB/OFPP. FEMP began actively working with many Federal agencies to implement the Challenge program during FY 1994, hosting bi-monthly meetings with agency representatives.

FEMP has a broad mandate for promoting energy efficiency in the Federal Government, and product energy efficiency is being incorporated into many active programs. Both EPACT and Executive Order 12902 assign DOE a technical advisory role in the identification of energy efftcient products. Since the Federal Government is such a large buyer of energy-related products and services, part of the effort during FY 1994 focused on determining more precisely what and how much is bought by each agency. This assessment, along with a better understanding of how the Federal procurement system operates, is an important step in having a greater influence on purchasing decisions, and therefore, a major impact on energy consiomption.

Reflecting this broad orientation, DOE has identified three overall program objectives to guide procurement of energy efficient products. These are to make the Federal Government a leader in buying cost-effective, high-efficiency products, an environmentally responsible buyer, and a force for advancement of energy efficiency in the marketplace.

Another DOE FEMP activity explicitly directed by EPACT is a study to investigate the potential for using Federal purchasing power to promote the development and commercialization of energy efficient products. This initiative centers on products with commercial potential, but which are not commercially produced. This effort is to be conducted in consultation with utilities, manufacturers and other interested organizations. A public meeting is planned for 1995 to develop a list of candidate products and a plan for implementation. As candidate products are identified they will be incorporated into the Federal Procurement Challenge.

In addition to programs directly focused on energy efficient purchasing, other FEMP programs indirectly promote energy efficient products. These include programs in specific areas, such as the Federal Relighting Initiative, and those with a broader scope, such as the SAVEnergy program for audits of Federal boildings. In addition, FEMP's extensive training corriculum and interagency outreach include promotion of energy efficient products.

Other DOE offices are promoling high efficiency products also. For example, DOE's "market transformation" program includes Federal procurement of high efficiency exuipment, including residential appliances and building heating, ventilating and air conditioning (HVAC) egraipment. Initiated in response to EPACT, this program aims to change the market in a fundamental way so that demand for highly efficient equipment becomes permanent.

There are numerous programs and activities already underway which promote energy efficient procurement. Both DLA and GSA have active programs which include product energy efficiency. Special publications either focus on or include energy efficiency, such as the Energy Efficient Lighting Catalog published by DLA's Defense General Supply Center and GSA's Environmental Products Guide. Both supply agencies are developing other resources to educate their customers on energy efficiency. For example, GSA, DLA, DOE and EPA are establishing a common symbol to identify energy efficient products, to be used throughout Federal procurement and supply. Both GSA and DLA also provide training and workshops which include energy efficiency information. 
The Bnvironmental Protection Agency has targeted energy savings as a means of reducing carbon ditoxide emissions and preventing pollution through its Energy Star labeling program. This program initially focused on office equipment because of its rapid growth in sales and the concomitant increase in energy use over the past decade. The program was given a major boost when Executive Order 12845 was issued, directing all Federal agencies to purchase Energy Star computer equipment. The Energy Star labeling program is now being expanded to include other office equipment, as well as residential HVAC and appliances.

DOE and other Federal agencies are supporting several non-Federal programs which promote energy efficient products, including the Energy Efficient Procurement Collaborative, spearheaded by the State of New York. The goal is to improve the overall purchasing practices of government at the state and local levels and influence industry to develop more highefficiency products. The Collaborative is developing voluntary procurement policies, consensus efficiency guidelines and specifications, and data systems. Another non-Federal organization, the Consortiun for Energy Efficiency, has initiated programs to create market pull for high efficiency products and to support the objectives of its member utilities' deraand-side management prograns.

\section{H. Public Education Programs}

Section 551(b) of NECPA requires the Secretary of Energy to include in this and subsequent atmual teports infortmation on public education programs carried out by Federal agencies and previously reported under the authority of section 381 of the Energy Policy and Conservation Act (EPCA), as amended, 42 U.S.C. \& 6361.

EPCA requires the Secretary of Energy to establish and carry out public education programs to encourage energy conservation and energy efficiency and to promote vanpooling and carpooling arrangements. The Department of Transportation (DOT) has promoted ride sharing activites, while DOE has been responsible for other energy conservation education programs.

In FY 1994, through its Federal Highway Adiministration, DOT obligated about $\$ 53$ million of Federal atd funds to assist State and local agencies in implementing programs, designed to enconrage the use of car pools, van pools, and buses by commuters. DOT efforts have included van pool acquisition programs, fringe and corridor parking facilities, ride-matching projects, preferential treatments for high occupancy vehicles, and transit service improvement. Since 1974, nearly $\$ 466$ million in Federal-aid highway funds has been spent on such projects in an effort to establish self-sufficient programs across the Nation.

During FY 1994, a new series of reports was published and distribated through the DOT Technology Sharing Program. "Iraplementing Effective Travel Demand Management Measures: Inventory of Measures and Synthesis of Experience" is one of three current reports available that is based on joint research on Travel Demand Management (TDM) by the Federal Fighway Administration and the Federal Transit Administration. Over 2,000 copies of this report have been distributed during FY 1994. The other two reports are entidled "Guidance Manual for Implementing Effective Employer-based Travel Demand Management Programs" and "Overview of Travel Demand Management Measures," Other planned reports on this topic will address Government-based TDM programs and market research in TDM. A microcomputer 
analysis tool (with focunentation) for the evaluation of TDM projects is also available through the University of Flocida, Center for Microcomputers in Transportation, 512 Weil Hall, Gainesville, FL 32611-6585; telephone: 800-226-1013.

All of these reports and analysis tools are intended to provide technical assistance to individuals in the public and private sectors who are responsible for planning, implementing, operating, and/or monitoring TDM activities. They also are designed to educate these individuals on the state-of-the-practice and guide in the development of TDM programs.

The Department of Energy's public education programs encompass a wide variety of services, objectives, and audiences, covering all major areas of conservation and renewable energy. DOB has organized its technology transfer programs to meet the specific information requirements of various audiences.

In January 1994, two DOE information services, the Conservation and Renewable Energy Inquiry and Referral Service and the National Appropriate Technology Assistance Service, were combined and are now known as the Entergy Efficiency and Renewable Energy Clearinghouse (EREC). EREC provides basic, technical, and finarcial information on various energy efficiency/renewable energy technologies and programs. The audience served by EREC includes the general poblic, business and industry, educational community, media, utility companies, and state and local governments. Information is provided in the form of fact sheets, DOE and National Laboratory books and brochures, bibllographies, and on-line computergenerated technology synopses. In FY 1994, EREC disseminated over 130,000 publications in response to approximately 45,000 inguiries,

The National Energy Information Center (NEIC) responds to public and private sector questions on energy production, consumption, prices, resource availability, and projections of supply and demand. It also makes available the publications, and data tapes profuced by the DOE Energy Information Administration. NEIC provides information on an on-line bulletin board service (202) 586-2557 that permits access by Federal employees and the public. Electronic inquiries may be sent via Internet at the following address infoctr@eia.doe.gov. In 1994, NEIC staff responded to 42,000 inquiries and distributed approximately 80,000 publications.

The Office of Scientific and Techrical Information (OSTI) provides coordination and direction for the managentent of scientific and technical information resulting from the DOE's multibillion dollar research and development activities. In support of national competitiveness, OSTI collects, processes, and disseminates all DOE-originated research information and selected worldwide research literature on subjects of interest to domestic communities. OSTI is responsible for providing centralized scientific and technical information (STI) services to, or on behalf of, DOE elements in support of Departmental mandates, missions, and objectives. OSTI served the public directly or indirectly through agreements with the National Technical Information Service, Government Printing Office, depository libraries, and commercial vendors. OSTI also assisted in the development of the Internet based DOE Home Page, which is accessed over 20,000 dimes per month by individuals seeking information about DOE.

OSTI manages a comprehensive collection of approximately one millon scientific and technical information documents, representing nearly 50 years of energy-related activities, and maintains 
the Energy Science and Technology Database (EDB), which has over three mitlion summaries of DOE and worldwide information. The database is made available to the public on-line and on CD-ROM through commercial vendors. The majority of its users are industry, federal, and state officials, contractors, libraries, reseanch institutions, and the public. In FY 1994, OSTI added 175,000 research summaries to the database and provided 21,000 fult-text documents for public availability to the National Technical Information Service and the Govemment Printing Office Depository Library Program. Other services include printing and publishing for DOE offices; providing inforration management advice and consultation to the Departmental commanity; managing and disseminating DOE and Nuclear Regulatory Commission scientific and technical software; and representing the United States in multilateral and bilateral intemational information exchange agreements.

The Technical Information Program, operated by the National Renewable Energy Laboratory, provides information on energy efficiency and renewable energy to decision-makers at the Federal, State, and local levels as well as professionals in the buildings, industrial, utilities, and transportation sectors. TIP develops and produces communications products in support of EERE goals and technologies, including brochures, fact sheets, resource directories, videos, exhibits, and compilations of photos and docaments.

The DOE public information mechanisms include several direct service prograns designed to provide technical assistance to specific target groups. Some of these include:

- the Institutional Conservation Program (ICP), which encourages investment in energy conservation for public and private schools and hospitals through matching grants for engineering analyses and retrofit activities. Since its inception in 1979, 15,634 schools, 5,518 hospitals, and 4,982 colleges have participated in ICP programs. In FY 1994, funding for state grants was $\$ 29$ million;

- the Energy Analysis and Diagnostic Center (EADC), which stimulates industrial energy conservation through audits of manufacturing prosesses conducted by students and faculties from participating accredited engineering schools (currently 30 schools); conducted 5100 energy efficiency audits, and at the end of FY 1994 had 280 students in training.

- the Pre-Freshman Enrichment Program (PREP), which provides funding for summer seminars in math and science-based subjects at colleges and universities nationwide and is targeted at underrepresented populations.

The Office of Federal Energy Management Programs (FEMP) Help Desk provides Federal energy managers with specialized information on effective energy management practices, technical assistance on implementing Federal sector energy projects, financing information, energy modeling software, publications, and energy management training programs. The primary goal of this service is to assist Federal agencies in meeting the legislative requirements. The Help Desk responds to requests for infomation via a toll-free automated telephone service, electronic mail, and through the Internet. During FY 1994, this service nesponded to over 1,600 technical inquiries of which over 90 percent were from Federal energy managers.

A full list of DOE's energy education, extension, and information services is Appendix $F$ to this report. 


\section{ENERGY MANAGEMENT IN BUILDINGS AND FACILITIES}

\section{A. Energy Consumption and Costs for Buildings and Facilities}

The Federal Govemment provides energy to approximately 500,000 buildings and facilities comprising approximately 3.1 billion square feet of floor area. This energy is used to provide lighting, heating, ventilation, air conditioning, and other standard building services, as well as a significant amount of process operations that are not reported separately. ${ }^{2}$ Both the magnitude of energy consumption and the potential for energy savings have prompted legislative and executive branch intititives to achieve energy conservation in the Federal buildings sector. ${ }^{13}$ Sextion $\Pi(B)$ describes major legislative requirements and highlights agency progress in meeting goals. Section V of this report discusses individual agency efforts in greater detail.

Table 4 shows that agencies have decreased overall buildings energy consumption by 18.2 percent, from 470.9 trillion Btu in FY 1985 to 385.0 trillion Btu in FY 1994. A comparison to FY 1993 shows a decrease of 4.5 percent in total buildings energy consumption. The State Department's 83.1 percent increase from the previous year is attribatable to the redesignation of some of its properties from the "excluded" category.

Of the 26 agencies represented on the table for FY 1994, 11, including DoD, consume over 98 percent of the reported butldings energy. Energy used in buildings accounts for approximately 32.1 percent of the total 1.20 quads used by the Federal Govermment. The mix of Federal buildings energy for Defense and civilian agencies is depicted in Figure 4. Electricity constioutes 40.4 percent (155.6 TBtu) of Federal buildings energy; 32.4 percent is accounted for by natural gas (124.5 TBtu), and 15.0 percent by fuel oil (57.6 TBtu). Small amounts of coal, purchased steam, liquefied petroleum gas (L.PG)/propane, and "other" energy (comprised mainty of chilled water and renewable energy), account for the remaining 12.2 percent.
FTGURE 4

Defense asd Civilian Eatray Consumption in Buildings and Facilities by Fuel Type, FY 1994

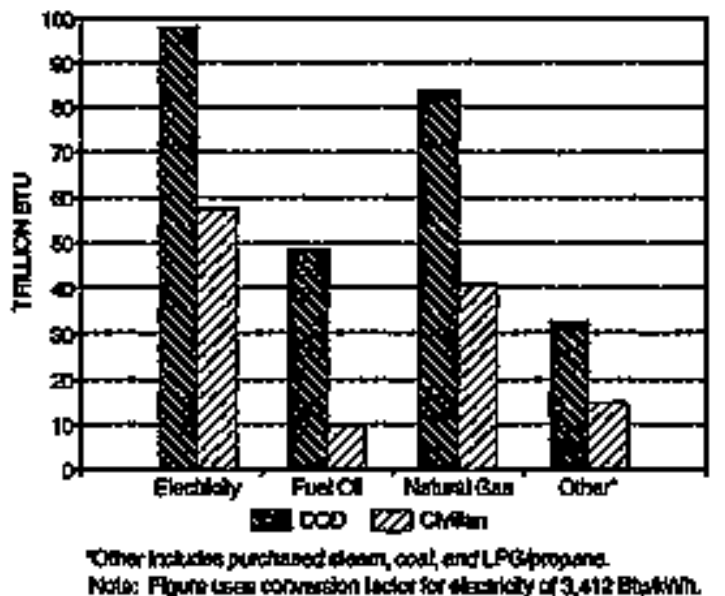

Figure 5 ilhustrates the proportion of energy consumption in buildings and facilities that is attributable to electricity for the fiscal years 1985 through 1994 . The figure also breaks out the amount of Btu lost through the generation and transmission processes and amount of Bty delivered to the site. In FY 1994, electricity consumption, including energy used at the source

\footnotetext{
${ }^{12}$ Process energy is that energy used in buildings for operations other than standard building services. In cases where separate reportint was not possible, due to the lack of meters or estination techniques, process energy was reponted as though it were part of the energy used for standard building services.

Ise legislative authorities for Federal agencies and are detailed in Appendix A.
} 
TABLE 4

FEDERAL ENERGY CONSUMPTION IN BUILDINGS AND FACILITIES

(In Billions of British Thermal Units, Miltions of Barrels of Oil Equivalent [MBOE], and Petajoules [Joule x 10 15])

\begin{tabular}{|c|c|c|c|c|c|c|c|c|c|c|c|c|}
\hline $\begin{array}{l}\text { GIVILIAH } \\
\text { HOENCY }\end{array}$ & 1905 & 1966 & $\begin{array}{l}\text { Ex } \\
196 ?\end{array}$ & $\begin{array}{c}\text { ET } \\
1986\end{array}$ & $\begin{array}{c}\text { CY } \\
1989\end{array}$ & 1990 & $\begin{array}{l}\mathbf{F Y} \\
1991\end{array}$ & $\underset{1998}{F r}$ & ${ }_{1993}^{F Y}$ & ${ }_{1994}^{F I}$ & $\begin{array}{l}\text { CHANaE } \\
\text { AS-9\$ }\end{array}$ & 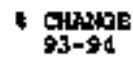 \\
\hline 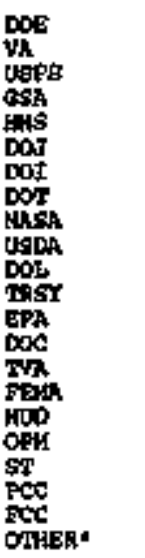 & 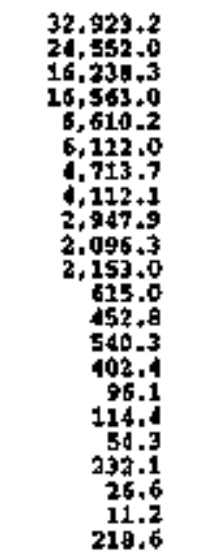 & 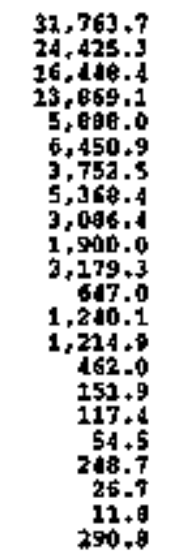 & $\begin{array}{r}30,510.1 \\
24,217.5 \\
16,751.6 \\
12,971.1 \\
6,200.9 \\
5,928.1 \\
3,654.6 \\
3,928.4 \\
3,108.0 \\
2,130.7 \\
2,153.2 \\
1.496 .1 \\
1,136.6 \\
1,136.3 \\
156.6 \\
153.9 \\
119.4 \\
54.5 \\
275.3 \\
23.3 \\
12.6 \\
362.7\end{array}$ & $\begin{array}{r}31,795.4 \\
25,625.0 \\
17,64.9 \\
12,267.8 \\
6,100.3 \\
7,455.7 \\
3,978.5 \\
3,953.9 \\
3,094.0 \\
1,026.5 \\
7,230.7 \\
4,196.9 \\
401.7 \\
1,294.2 \\
452.5 \\
271.5 \\
123.8 \\
67.3 \\
263.9 \\
28.4 \\
13+4 \\
391+1\end{array}$ & $\begin{array}{r}29,875+0 \\
25,819+8 \\
19,225.3 \\
13,550.2 \\
5,925.0 \\
5,597.0 \\
1,073.2 \\
3,369+5 \\
3,246+4 \\
1,957.7 \\
2,191.1 \\
2,529.2 \\
399.6 \\
2,325+1 \\
117.2 \\
192.5 \\
139.1 \\
72+1 \\
254.2 \\
26.2 \\
23.1 \\
137.0\end{array}$ & 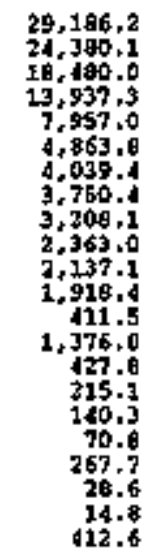 & $\begin{array}{r}27,975.9 \\
24,733+0 \\
18,630.6 \\
13,216.3 \\
7,107.2 \\
5,994.3 \\
3,966+2 \\
3,297.6 \\
3,000+5 \\
3,342.4 \\
2,044.1 \\
1,494+7 \\
1,406.4 \\
1,426.6 \\
198.4 \\
129.6 \\
74.6 \\
274+2 \\
32.4 \\
24.9 \\
230.8\end{array}$ & 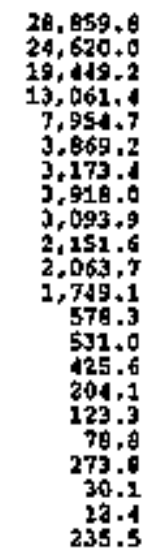 & 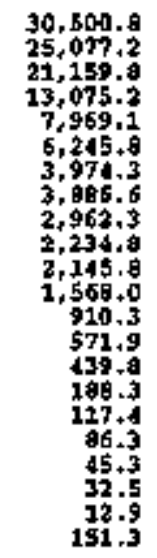 & $\begin{array}{r}29,482.4 \\
25,213+4 \\
21,602.2 \\
12,832.9 \\
9,231.9 \\
6,143.9 \\
3,922.1 \\
3,903.0 \\
3,010.8 \\
2,164.5 \\
2,158.3 \\
2,624+7 \\
951.6 \\
752.9 \\
642.2 \\
172.9 \\
119.8 \\
84.3 \\
82.9 \\
31.4 \\
14.1 \\
144.6\end{array}$ & $\begin{array}{r}-13.5 \\
3.7 \\
33.0 \\
-22.5 \\
24.5 \\
0.5 \\
-16.8 \\
-5.1 \\
2.7 \\
3.3 \\
0.2 \\
164.2 \\
\pm 10.1 \\
39.3 \\
69.5 \\
86.6 \\
-0.5 \\
59.9 \\
-64.3 \\
17.2 \\
26.6 \\
-33.0\end{array}$ & $\begin{array}{r}-6.6 \\
0.5 \\
2.1 \\
-1.9 \\
3.3 \\
-1.6 \\
-1.3 \\
0.3 \\
1.6 \\
-3.1 \\
0.6 \\
3.6 \\
4.5 \\
31.6 \\
35.1 \\
-8.2 \\
-3.0 \\
0.40 \\
13.2 \\
-3.6 \\
9.0 \\
-4.4\end{array}$ \\
\hline Crvititan & 172,785,7 & 119.697 .6 & 116.715 .9 & $123,335,6$ & $117,985.7$ & $119,306.0$ & 116.701 .7 & $126,436.5$ & $123,355.6$ & 122.322 .9 & 0.6 & -0.0 \\
\hline$D O D$ & $349,076,7$ & $327,583.1$ & 351.862 .9 & $319,676+4$ & $322,205.6$ & $321,101.6$ & 206.065.7 & $295,719.8$ & $279,726.5$ & $262,651.5$ & -24.6 & -8.1 \\
\hline 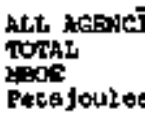 & $\begin{array}{r}\mathrm{TES} \\
470,062.4 \\
96.9 \\
496.7\end{array}$ & $\begin{array}{r}14.180 .9 \\
76.0 \\
171.6\end{array}$ & $\begin{array}{r}467,999.9 \\
60.3 \\
493.7\end{array}$ & $\begin{array}{r}443.272 .3 \\
76.1 \\
667.6\end{array}$ & $\begin{array}{r}440,151.3 \\
75.6 \\
164.3\end{array}$ & $\begin{array}{r}440.687 .5 \\
75.7 \\
464.9\end{array}$ & $\begin{array}{r}403 ، 593.5 \\
59.3 \\
125.6\end{array}$ & $\begin{array}{r}112.176 .2 \\
70.8 \\
434.8\end{array}$ & $\begin{array}{r}103.002 .3 \\
69.3 \\
125.2\end{array}$ & $\begin{array}{r}384.994 .4 \\
56.3 \\
406.1\end{array}$ & -18.2 & -4.5 \\
\hline 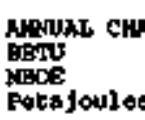 & WWGE FHOK 1985 & $\begin{array}{r}-23.691 .5 \\
-4.1 \\
-25.0\end{array}$ & $\begin{array}{r}-2,863.6 \\
-0.5 \\
-3.6\end{array}$ & $\begin{array}{r}-27.651 .1 \\
-4.7 \\
-20.2\end{array}$ & $\begin{array}{r}-30.711 .7 \\
-5.3 \\
-32.4\end{array}$ & $\begin{array}{r}-30.174 .9 \\
-51.2 \\
-31.8\end{array}$ & $\begin{array}{r}-67,369.9 \\
-11.5 \\
-71.0\end{array}$ & $\begin{array}{r}-59,686.7 \\
-10+1 \\
-61.5\end{array}$ & $\begin{array}{r}-67.780 .1 \\
-11.6 \\
-71.5\end{array}$ & $\begin{array}{r}-85 \text { a } 18.0 \\
-14.7 \\
-90.6\end{array}$ & & \\
\hline 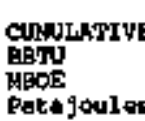 & & $\begin{array}{r}1985 \\
23.681 .5 \\
-\quad 25.1\end{array}$ & $\begin{array}{r}26,545,2 \\
28.6 \\
28+0\end{array}$ & $\begin{array}{r}54.196 .2 \\
99.3 \\
57.2\end{array}$ & $\begin{array}{r}84,907.2 \\
14.8 \\
69.6\end{array}$ & $\begin{array}{r}115.089 .1 \\
19+8 \\
121.4\end{array}$ & $\begin{array}{r}983,351.0 \\
31.3 \\
392.4\end{array}$ & $\begin{array}{r}241.037 .2 \\
41.4 \\
254.3\end{array}$ & $\begin{array}{r}309,817.2 \\
53.0 \\
325.6\end{array}$ & $\begin{array}{r}394,695.7 \\
67+8 \\
416.4\end{array}$ & & \\
\hline
\end{tabular}

* Other tncludes for centain years the Conmodity Futures Trading Conmission, Equal Employment Oppoxtumity Commission, Federal Trade Conmission, Nationtal Archives

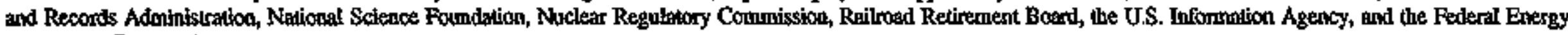
Regulatory Commission.

Note: FY 1994 contains estimated data for the followite ageacies: Department of Treasury, Federal Trade Commission and Office of Personnel Management. This table uses a conversion factor for electricity of 3,412 Bat per kilowatt hour. Sum of comporests may trot equal total due to independent rounding.

Souce: Agency Annual Energy Management Daka Reports 
FIGURE 5

Consumption of Electricity and Other Fuels

in Buildings and Facilities,

FY 1985 through FY 1994

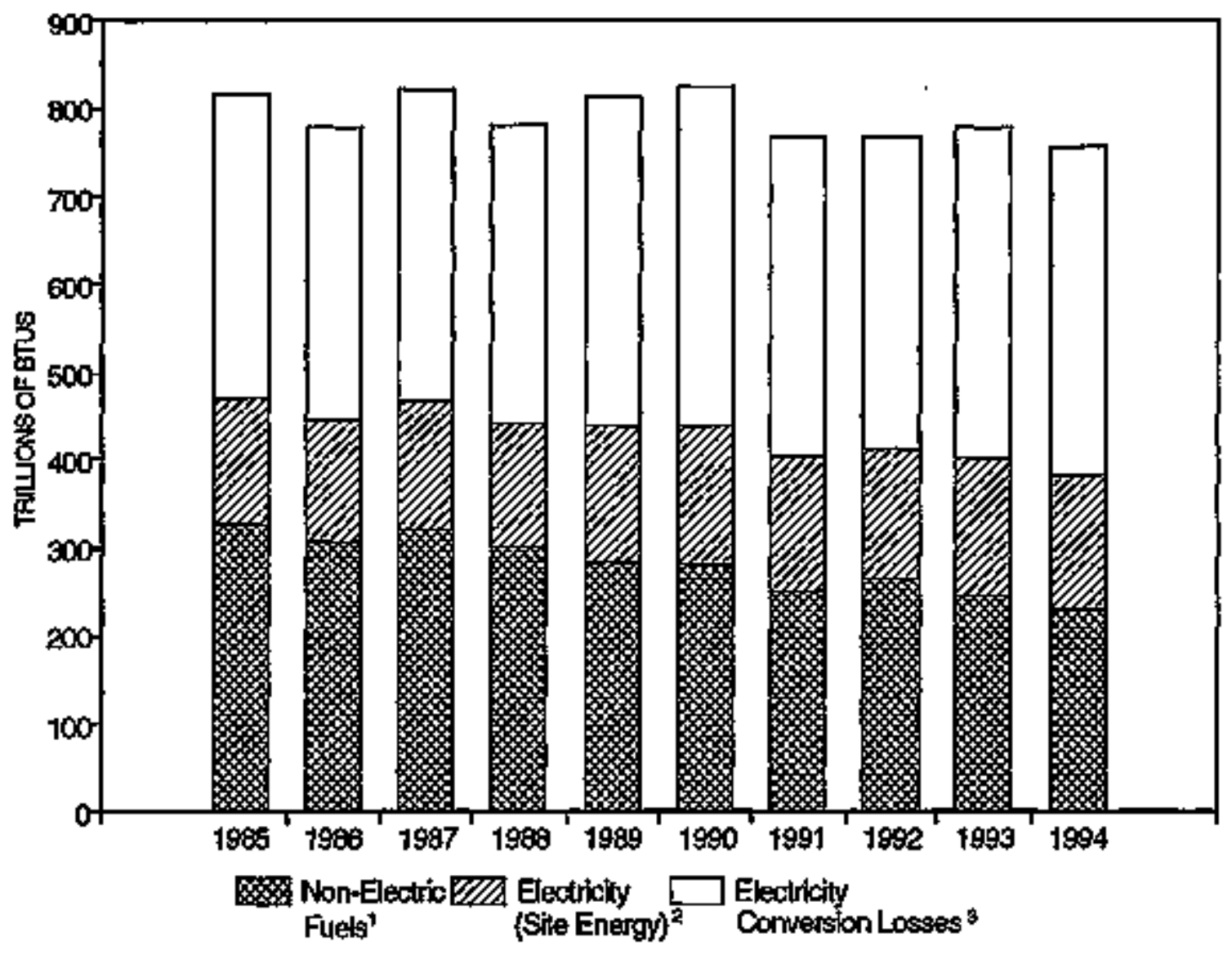

'Includes Fued Oil, Natural Gas, LPGPPropane, Coal, Purchased Steam, and Other. Uses a cooverston factor for steam of 1,390 Btu pet pound (source conversion).

2Uses a conversion factor of 3,412 Buj per kilowatt bour. Amsount of energy which reaches the site of use whan generation and transmission losses ane subtracted.

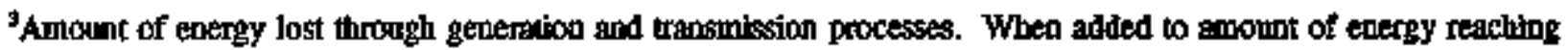
the point of use, the toatl equals amount of Bus consumed at the source. 'The source conversion factor is 11,600 Bup per kikwall hour.

Soucce: Federal Agency Annusal Energy Management Data Repcrils 
of generation, accounted for approximately 69.2 percent of the total gross Btu consumed in bnildings and facilities. Of this amount, approximately 29.4 percent or 155.6 trillion Bto reached the site of use. The nemaining 70.6 percent, 373.3 trillion Btu, was lost during the generation and transmission processes.

Decresses in consumption relative to FY 1993 were seen in every energy type except for fuels reported under the category of "other," which increased 2.5 percent. Decreases from the previous year were evident in electricity (1.1 percent), natural gas (6.5 percent), LPG/propare (8.3 percent), fuel ail (7.2 percent), coal ( 8.4 percent), and purchased steam ( 2.5 percent).

As shown in Table 5, fuel switching and conservation of fuel oil and LPG/propane in buildings contributed to a 45.4 percent decrease in conspmption of petroleum-based fuels in buildings compared to FY 1985 and a 7.3 percent decrease from FY 1993. These reductions are partially attributable to efforts by agencies to utilize natural gas as a cost-effective substifute for petroleum-based fuels in buildings. Petroleum fuel consumption in buildings during FY 1994 represented only 15.8 percent of all energy consumed in Federal buildings. Of this amount, 94.9 percent is attributed to fuel oil and the remaining 5.1 percent to LPG/propane.

The energy used in boildings in FY 1994 accounted for approximately 47.5 percent of the total Federal energy bill. Tables 6-A and 6-B show that the Federal Government spent approximately $\$ 3,821.2$ million for bulldings energy during the fiscal year, a decrease of approximately $\$ 91.8$ million from FY 1993 expenditures. The average cost for buildings energy in FY 1994 was $\$ 9.93$ per million Btu, up 2.2 percent from the average cost of $\$ 9.71$ reported in FY 1993 (see Appendix C).

Figure 6-A illustrates energy expenditures for buildings and facitities in nominal current year dollars for FY 1985 through FY 1994. Figure 6-B depicts energy expenditures in constant dollars for the same period to address the infuence of inflation. In constant 1987 dollars, Federal energy costs for buildings and facilities decreased 28.2 percent from $\$ 4,218.0$ million in FY 1985 to $\$ 3,030.3$ million in FY 1994. The average cost for buildings energy in constant dollars in FY 1994 was $\$ 7.87$ per million Btu, down 12.2 percent from $\$ 8.96$ per million Btu in

FIGURE 6*A

Energy Expendifures (Nominal Dollars) in Buildings and Facilities FY 1985 - FY 1994

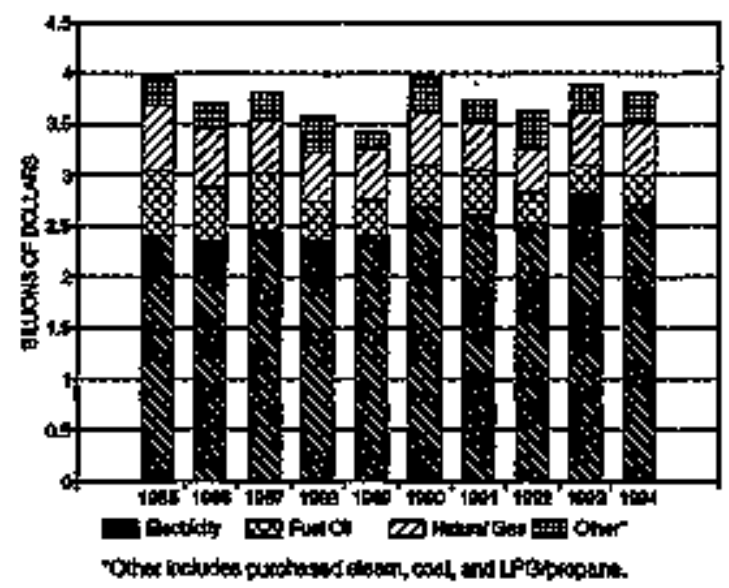

FGURE 6-B

Energy Expenditures (Constant Dollars*) In Bu1ldings and Facilities FY 1985 - FY 1994

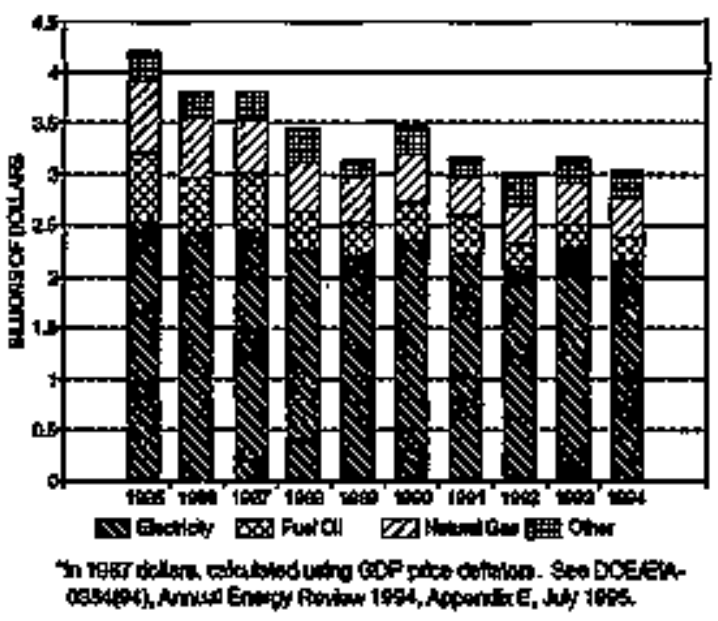


TABLE 5

PETROLEUM-BASED FUEL* CONSUMPTION IN BUILDINGS AND FACILITIES

(In Billions of British Themmal Units)

\begin{tabular}{|c|c|c|c|c|c|c|c|c|c|c|c|c|}
\hline Ac:Bicy & $\underset{1965}{F F}$ & $\underset{394}{F Y 6}$ & $\underset{1997}{7 y}$ & $\underset{1900}{F Y}$ & 1969 & $\begin{array}{c}F y \\
1990\end{array}$ & 199 & $\underset{1992}{F T}$ & $\underset{19}{T y}$ & $\begin{array}{c}E Y \\
1994\end{array}$ & 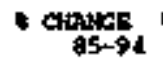 & $\begin{array}{l}\text { - CHANBS } \\
93-94 \\
9\end{array}$ \\
\hline 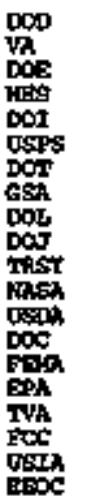 & 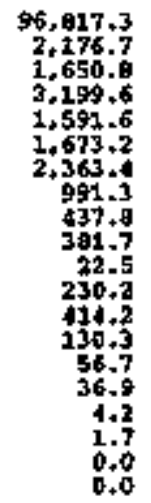 & $\begin{array}{r}85,607.3 \\
3,118.5 \\
1,257.1 \\
2,690.6 \\
1,130.7 \\
1,591.6 \\
3,561.0 \\
667.6 \\
114.5 \\
363.4 \\
25.4 \\
233.2 \\
360.7 \\
95.5 \\
62.8 \\
45.5 \\
2.9 \\
1.6 \\
0.0 \\
0.0\end{array}$ & $\begin{array}{r}90,403.2 \\
2.261 .3 \\
1.496 .0 \\
2,643.0 \\
1.272 .1 \\
1.596 .3 \\
2.107 .2 \\
530.3 \\
127.0 \\
463.3 \\
172.9 \\
262.0 \\
192.0 \\
79.9 \\
73.2 \\
14.9 \\
1.6 \\
1.4 \\
0.0 \\
0.0\end{array}$ & $\begin{array}{r}79.345 .1 \\
2.168 .2 \\
1.547 .1 \\
2,000.1 \\
2.364 .7 \\
1.602 .6 \\
2.100 .0 \\
561.8 \\
397.3 \\
930.3 \\
794.2 \\
253.1 \\
206.4 \\
9.1 \\
77.0 \\
0.0 \\
3.0 \\
3.7 \\
0.0 \\
0.0\end{array}$ & $\begin{array}{r}70,701.8 \\
2,32.8 \\
1,357.1 \\
2,059.8 \\
2,376.7 \\
1,355.7 \\
1.534 .8 \\
544.0 \\
39.5 \\
310.4 \\
319.3 \\
39.2 \\
229.1 \\
76.8 \\
79.8 \\
0.0 \\
1.2 \\
1.5 \\
0.0 \\
2.3\end{array}$ & $\begin{array}{r}69.030 .1 \\
2,219.3 \\
1,953.8 \\
2,130.7 \\
1.273 .9 \\
1.502 .2 \\
1.524 .2 \\
659.1 \\
331.2 \\
371.6 \\
291.3 \\
277.6 \\
260.0 \\
77.6 \\
72.3 \\
0.0 \\
3.2 \\
1.9 \\
0.0 \\
1.9\end{array}$ & $\begin{array}{r}59,457.5 \\
1,464.9 \\
1,978.2 \\
1,54.9 \\
1,141 . \pm \\
1,219.4 \\
1,309.4 \\
413.1 \\
258.3 \\
503.7 \\
127.7 \\
161.6 \\
29 . .3 \\
13.7 \\
59.1 \\
0.0 \\
0.1 \\
1.0 \\
0.0 \\
0.0\end{array}$ & $\begin{array}{r}65.654 .1 \\
1,506.0 \\
3,034.7 \\
2,144.2 \\
919.1 \\
2,195.8 \\
1,426.0 \\
919.2 \\
263.6 \\
363.8 \\
04.2 \\
217.6 \\
242.9 \\
9.8 \\
66.9 \\
1.9 \\
1.3 \\
1.3 \\
0.3 \\
0.0\end{array}$ & $\begin{array}{r}55,595.9 \\
1,533.9 \\
1,942.8 \\
1,765.2 \\
1,181.9 \\
998.8 \\
954.0 \\
359.4 \\
276.1 \\
250.6 \\
190.5 \\
134.5 \\
255.6 \\
23.6 \\
67.6 \\
15.5 \\
2.7 \\
1.3 \\
0.0 \\
0+0\end{array}$ & $\begin{array}{r}50,265.7 \\
1.827 .4 \\
1,924.4 \\
1,525.7 \\
1,560.6 \\
993.7 \\
1,001.6 \\
379.8 \\
237.5 \\
234.0 \\
160.6 \\
139.6 \\
236.3 \\
52.4 \\
49+1 \\
33.6 \\
3.5 \\
1.3 \\
0.0 \\
0.0\end{array}$ & 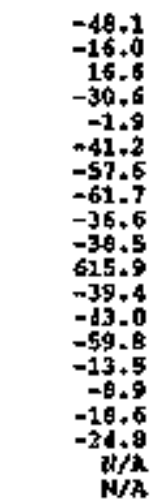 & $\begin{array}{r}-9.5 \\
19.1 \\
-0.9 \\
-13.6 \\
32.0 \\
-0.5 \\
17.3 \\
5.7 \\
0.5 \\
-5.4 \\
-15.5 \\
3.9 \\
-7.6 \\
120.3 \\
-27.4 \\
117.3 \\
27.9 \\
-2.1 \\
1 / 4 \\
\mathrm{w} / \mathrm{A}\end{array}$ \\
\hline COTAL & $111,100.2$ & 100.403 .4 & $103,953.1$ & $92,295,9$ & $83,523.3$ & $91,989,0$ & $69,900.2$ & 76.571 .7 & $65,130.2$ & $60,677,0$ & -65.1 & -7.3 \\
\hline
\end{tabular}

Petrolem-based fuels include fuel oil and LFGipropane.

Note: FY 1994 contains estimated data for the forlowing agencies: Department of Treasury, Foderal Trade Comamission, and Office of Pensifunel Management Sum of componemts may not equeal wotal dus to independent rouvding.

Sounce: Federad Agency Anaual Energy Memagenteat Data Reports 
TABLE 6-A

DEFENSE AND CIVILIAN FEDERAL COSTS FOR BULDDNGS ENERGY IN FY 1994 (IN MILLIONS OF NOMINAL DOLLARS)

\begin{tabular}{|c|c|c|c|c|c|c|c|c|}
\hline & SLECTRICITY & STEL OAt & $\underset{\text { GAS }}{\text { MATURAL }}$ & $\begin{array}{l}\text { LAO/ } \\
\text { PROPNAE }\end{array}$ & cons & $\begin{array}{l}\text { POHCHASED } \\
\text { FTEAH }\end{array}$ & OTHER & Topat \\
\hline \multirow[t]{2}{*}{$\begin{array}{l}\text { DEFENSE } \\
\text { CIVLIAN }\end{array}$} & $\begin{array}{l}1.665 .279 \\
1.055 .586\end{array}$ & $\begin{array}{r}242.169 \\
40.572\end{array}$ & $\begin{array}{l}326.683 \\
174.691\end{array}$ & $\begin{array}{r}13.555 \\
6.557\end{array}$ & $\begin{array}{l}59.272 \\
16.905\end{array}$ & $\begin{array}{r}172.022 \\
45.315\end{array}$ & $\begin{array}{l}2.539 \\
2+479\end{array}$ & $\begin{array}{l}2,479 \cdot 819 \\
1,341.347\end{array}$ \\
\hline & 2.720 .865 & 293.041 & 501.574 & 30.152 & 75.177 & 217.337 & 3.018 & $3,871.166$ \\
\hline
\end{tabular}

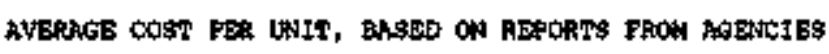

\begin{tabular}{|c|c|c|c|}
\hline 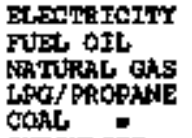 & & $\begin{array}{r}59.67 \\
0.68 \\
4.15 \\
0.62 \\
64.59\end{array}$ & 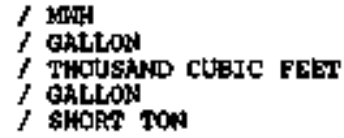 \\
\hline $\begin{array}{l}\text { 5TYAH } \\
\text { OITEER }\end{array}$ & & $\begin{array}{r}14,43 \\
5.64\end{array}$ & f MLLLTOA Bru \\
\hline
\end{tabular}

Note: Contains estimated data for the following agenctes: Federal Trate Commission and Office of Personad Management. Sum of components may wo equal total doe to independent rounding.

Sorrce: Arumal energy cost data submitted to DCE by Federal agencies. 


\section{TABLE 6-B \\ CONSUMPTION AND COSTS OF FEDERAL BUILDINGS ENERGY BY FUEL TYPE IN FY 1994, FY 1993, AND FY 1985 (NOMINAL DOLEARS)}

FY 1994

RANERCY TYPE

BILLIONS OF BIUs

COST PER MILLION

COST (IN MILLIONS

ELECTRICIIYY

FJET OIL

MATURAL GAS

LEG/ PROPANE

COAL

PURCHASED STEAM

OTHER

TORAL

$$
\begin{array}{r}
155,572.8 \\
57,569.3 \\
124,549.9 \\
3,108.5 \\
28,607.1 \\
15,059.7 \\
517.1 \\
384,984.4
\end{array}
$$

$$
\begin{array}{r}
17.4893 \\
4.9165 \\
4.0271 \\
6.4829 \\
2.5279 \\
14.4317 \\
5.8362
\end{array}
$$

OF DOLtaRS)

AVERAGE COST PER METU $=\$ 9.926$

FY 1993

EXERGY TYYE

ELECTRICITY

PUEL OIL

NATURAL GAS

LPG/ PROPANE

COAL

PURCHASED STEAM

OTHER

TOTAL

AVERAGE COST PER METU $=\$ \mathbf{9 . 7 0 8}$

PY 1985

ENRRGY TYYPE

$\begin{array}{lr}\text { ELECTRICITY } & 144,427.3 \\ \text { FUEL OIL } & 107,595.7 \\ \text { NATURAL GAS } & 144,458.6 \\ \text { WPG/ PROPANE } & 3,604.0 \\ \text { COAL } & 58,068.7 \\ \text { PURCHASED STEAM } & 7,998.2 \\ \text { ORHER } & 4,709.9 \\ & \\ \text { TOTAL } & 470,862.4\end{array}$

AVERAGE COST PER METU $=\$ 8.456$

403.082 .3
BIUTIONS OF COST PER MILLION BTUs

$$
\begin{array}{r}
17.9084 \\
4.7752 \\
3.7930 \\
6.2064 \\
2.0078 \\
13.4765 \\
4.7605
\end{array}
$$
504.4

$157,316.2$

$62,038.2$

$3,391.5$

$31,213.7$

2.720 .865

283.041

501.574

20.152

75.177

217.337

3.018

$3,821.166$

COST ITN MILLIONS OF DOLLARS)

$2,817.278$ 296.246

505.113

21.049

62.669

208.207

2.401

$3,912.964$

COSP (IN MILLIONS OF DOLLARS)

$$
\begin{array}{r}
16.6341 \\
5.9355 \\
4.6144 \\
6.9170 \\
2.3472 \\
11.2765 \\
4.8185
\end{array}
$$

$2,402,422$

638.629

666.59 ?

24.929

136.296

90.192

22.695

$3,921.760$

DATA AS OF $07 / 22 / 95$

Note: FY 1994 contains extimated data for the following agencies: Department of Treasnry, Federal Trade Commission, and Office of Persomtel Management. This tabte uses a conversion factor for electricity of 3,412 Bm per kilowalt hour. Swm of components may not equal total dus to independent rounding.

Sounce: Federal Agency Antual Energy Menagement Dala Reports 
FY 1985. It should be noted that inter-year comparisons between FY 1985 and FY 1994 should be viewed with caution doe to flucwations in reporting and adjustments to yearly data by agencies excluding certain energy-intensive buildings and costs from their totals as provided for in section 543(a)(2) of NECPA.

Electricity costs of $\$ 2,720.9$ million represent approximately 71.2 percent of the total expenditures of $\$ 3,821.2$ million for buildings energy in FY 1994. Natural gas costs account for approximately 13.1 percent of the total, expenditures for fuel oil account for 7.4 percent, with the remaining 8.3 percent attributable to expenditares for LPG/propane, coal, purchased steam, and "other."

In FY 1994, the cost of all energy used in Federal buildings was $\$ 1.23$ per gross square foot. Of the $\$ 1.23$ spent per square foot Government-wide, $\$ 0.88$ was spent for electricity, $\$ 0.16$ was spent for natural gas, $\$ 0.09$ was spent for fiel oil, and the remaining $\$ 0.10$ was spent for purchased steam, coal, LPO/propane, and other fuels.

\section{B. Progress Toward the Mandated Goak for Buildings and Facilities}

Overall, the Federal Govemment reduced its energy consumption in buildings and facilities by 11.2 percent in FY 1994 compared to FY 1985 when measured in terms of British Thermal Units consumed per gross square foot (Btu/GSF) of floor area. Federal Government progress toward the 10 and 20 percent energy reduction goals of NECPA and Executive Order 12759 is illustrated in Figure 7. Table 7 illustrates the FY 1994 performance of the individual agencies in Btw/GSF compared to FY 1985. Contributing to the overall reduction of 11.2 percent were the percentage reductions made by the following agencies: I1.7 percent by the Department of Defense, 23.2 percent by DOE, 37.7 percent by the Department of Justice, 13.2 percent by the Department of Veterans Affairs and the Department of the Interior, 12.2 percent by the General Services Administration, 18.7 percent by NASA and 22.7 percent by the Federal Energency Management Agency.

These agencies ased a variety of srategies to reduce their energy consumption. Operations and maintenance (O\&M) procedures continued to be emphasized as a major component in the effort to achieve the energy reduction goals. Improvements in energy efficiency were achieved through improved energy systems operations and both greventive maintenance and improved maintenance. O\&M funding, used for the replacement of boilers, HVAC equipment, windows, and lighting systems, continued to benefit energy conservation.

In FY 1994, the implementation of many no-cost and low-cost energy conservation measures was continued, such as reducing lighting levels, lowering hot waser temperatures, turning off 
TABLE 7

FEDERAL BULDINGS AND FACULITIES USE PER GROSS SQUARE FOOT, FY 1985 AND FY 1994

\begin{tabular}{|c|c|c|c|c|c|c|c|c|}
\hline & & $\cos \times 20^{\circ}$ & $\begin{array}{l}\text { FISCAL YEAR } 1985 \\
\text { BTU } \times 10^{\circ}\end{array}$ & ETO/GSP & GSF $\times 10^{3}$ & $\begin{array}{l}\text { EISCAL YEAR } 1994 \\
\text { BHT } \times 10^{*}\end{array}$ & BAU/GEF & $\begin{array}{l}\text { \% CHAMKE } \\
1985-1994\end{array}$ \\
\hline E & 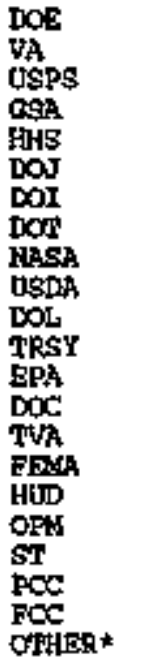 & $\begin{array}{r}73,093.1 \\
123,650.0 \\
199,400.0 \\
196,341.1 \\
22,611.3 \\
20,768.8 \\
54,140.8 \\
29,477.7 \\
11,509.0 \\
28,990.5 \\
19,268.3 \\
5,776.9 \\
1,455.0 \\
5,611.5 \\
-4,866.6 \\
1,606.0 \\
1,432.0 \\
853.9 \\
2,597.0 \\
492.5 \\
121.0 \\
1,090.6\end{array}$ & $\begin{array}{r}32,923.2 \\
24.552 .0 \\
16,238.3 \\
16,563.0 \\
6,610.2 \\
6,112.0 \\
4,713.7 \\
4,112.1 \\
2.947 .9 \\
2,096.3 \\
2,153.0 \\
615.0 \\
452.6 \\
510.3 \\
402.4 \\
96.1 \\
114.4 \\
54.3 \\
232.1 \\
26.6 \\
11.2 \\
218.6\end{array}$ & $\begin{array}{r}450,429 \\
198,560 \\
85,736 \\
94,358 \\
292,340 \\
294,289 \\
97,064 \\
139,497 \\
256,140 \\
73,336 \\
117,652 \\
106,453 \\
321,327 \\
96,292 \\
82,357 \\
155,579 \\
79,978 \\
63,609 \\
69,390 \\
54,079 \\
92,182 \\
199,962\end{array}$ & $\begin{array}{r}82,347.0 \\
146,250.0 \\
258,702.0 \\
173,353.9 \\
30,953.3 \\
33,506.5 \\
51,926.5 \\
31,130.1 \\
14,465.0 \\
33,400.0 \\
17,505.1 \\
10,423.4 \\
2,248.1 \\
6,609.0 \\
8,245.8 \\
1,411.0 \\
1,432.0 \\
939.4 \\
872.0 \\
512.4 \\
124.8 \\
1,820.8\end{array}$ & $\begin{array}{r}28,482.4 \\
25,213.4 \\
21,602.2 \\
12,632.9 \\
8,231.9 \\
6,143.9 \\
3,922.1 \\
3,909.0 \\
3,010.8 \\
2,164.5 \\
2,158.3 \\
1.624 .7 \\
951.6 \\
752.9 \\
692.2 \\
172.9 \\
113.9 \\
66.3 \\
92.9 \\
31.4 \\
14.1 \\
141.6\end{array}$ & $\begin{array}{r}345,682 \\
172,399 \\
83,502 \\
74,027 \\
265,009 \\
183,363 \\
75,532 \\
125,419 \\
200,145 \\
54,806 \\
123,297 \\
155,867 \\
423,270 \\
113,921 \\
92,736 \\
122,561 \\
79,978 \\
91,947 \\
95,115 \\
61,288 \\
113,141 \\
79,142\end{array}$ & $\begin{array}{r}-23.2 \\
-13.2 \\
-2.5 \\
-13.2 \\
-8.7 \\
-37.7 \\
-13.2 \\
-10.1 \\
-19.7 \\
-10.4 \\
4.6 \\
46.4 \\
36.0 \\
18.3 \\
0.5 \\
-22.7 \\
-0.5 \\
44.5 \\
5.4 \\
13.3 \\
22.7 \\
-60.1\end{array}$ \\
\hline & $\begin{array}{l}\text { CIVILIAN } \\
\text { TOOAAL }\end{array}$ & $\begin{array}{l}\text { AGENCIES } \\
793,171.9\end{array}$ & $121,765.7$ & 153,543 & 908.068 .2 & $122,322.9$ & 134,707 & -12.3 \\
\hline & DOD & $3,578,984.0$ & $\begin{array}{r}319.076 .7 \\
-\gamma\end{array}$ & 135,354 & $3,197.853 .0$ & $\begin{array}{c}362,651.5 \\
-\end{array}$ & $119,50 \mathrm{~g}$ & -11.7 \\
\hline & TOTAL & $3,372,155,9$ & $470,862.4$ & 139,632 & $3,105,920,2$ & $364,964.4$ & 123,952 & $-11,2$ \\
\hline & & & & & & & DAT & $07 / 20 / 95$ \\
\hline
\end{tabular}

"Olher includes the Federal Trade Commission, National Anchives and Reconds Administration, National Science Foundaion, Nuclear Regulntory Commission, Ratroad Retrentert Board, the U.S. Information Agency, ant the Federal Energy Rogulatory Commission.

Noter FY 1994 contains estimated data for the following agencies: Department of Treaswry, Federil Trade Courmission, and Office of Persontint Management. This table uses a conversion factor for elecricity of 3,412 Ben per kilowalt hour. Sum of exmponents may nox equal total doe to independent rounding.

Source: Federal Agency Amutal Eacrgy Management Data Reports 
untsed equipment, and installing energy-efficient windows, insulation, weather stripping, and set-back' thermometers.

Numerous energy-efficient building retrofits and energy conservation projects were undertaken to supplement the no-cost, low-cost measures. These initiatives can be categorized by lighting system replacement, HVAC equipment moderrization, building envelope improvements, and other miscellaneous projects, such as installation of energy management control systems. Utility-sponsored demand side management programs were often pursued as supplemental sources of funding, as well as shared energy savings contract initiatives.

Other energy conservation activities include energy awareness programs feanuing energy awareness serninars, the identification of no-cost or low-cost measures, the designation of building energy monitors, publication of materials promoting energy conservation, the procurement of energy-efficient goods and prodacts, increased maintenance training, and increased engineering assistance.

Performance toward the goals of NECPA and Executive Order 12759 is measered using sitebased conversion factors for electricity and steam consistent with the definition of "energy use" as defined in Executive Order 12759 as "energy used at a building or facility measured in terms of energy delivered to the building or facility." See Appendix D for equivalent source-based consumption.

A number of agencies began submitting energy data to DOE starting in FY 1989 in compliance with NECPA as amended by the Federal Energy Management Improvement Act of 1988 (Pub. L. 100-615). Among these agencies are the Department of State, the Office of Personnel Management, and the Federal Energy Regelatory Commission. These three agencies submitted historical energy data back to FY 1985. For FY 1990 and forwart, Federal Energy Regulatory Commission energy consumption is reported as part of DOE and is therefore grouped under the category of "Other." Other agencies grouped under the category of "Other" in the tables hatf no buildings data to report for FY 1985 . These agencies include the Federal Trade Commission, the National Archives and Records Administration, the Nuclear Regulatory Commission, the Railroad Retirement Boand, and the U.S. Information Agency. The National Science Foundation is also grouped under this category due to inconsistencies in its reporting.

In FY 1994, GSA continued to delegate building management authority to agencies that occupy buildings owned and operated by GSA. As a result, several agencies reported increased gross square footage and energy consumption relative to FY 1985, while GSA reported decreases in these categories during the same period. The GSA delegation accounts for the significant interyear changes in energy consumption reported by various individual agencies. Two agencies, the Department of Health and Human Services and the Deparment of Commerce, adjusted their baseline year consumption and GSF figares during FY 1988 to reflect GSA delegations. Much of the building space acquired by HHS is operated by the Social Security Administration. DOC added the Jeffersonville Federal Center to its data reports, which greatly increased its gross square footage. In addition, three Commerce Bureans, the Bureau of Economic Affairs, the National Technical Information Service, and the Patent and Trademark Office, all became eligible for reporting in FY 1989 as a result of leasing delegation. 
The Treasury Department's large increase in buildings energy consumption since FY 1985, is a result of the addition of the Internal Revente Service delegated buildings to the Department's building inventory. Also contributing to the increase were the addition, in FY 1989, of the Office of Thrift Supervision's square footage and the GSA delegation of building management authority for the Financial Management Service. The energy consumption and square footage for these delegated buildings were included in GSA's FY 1985 reports.

Figure 8 illustrates the range of energy intensity in agency buildings measured in terms of BtwGSF. DOE's high rate of Btu/GSF is the result of unmetered process energy reported under the builotings category. DOE estimates that approximately 80 percent of its building energy is consumed in unmetered process and production operations, with about 20 percent used for HVAC, lighting, and building services. If more than 80 percent of a facility's metered energy is dedicated to process operations, then the entire facility's energy is excluded from the buildings category, GSA's nelatively low Btw/GSF results from the lack of energy intensive activities (i.e., laboratories, hospitals, etc.) in space under its control. The wide range

FIGURE 8

Pauge of Fnergg Intensity (BTU/GSF) in Buildings and Factlities by Agency in FY 1994

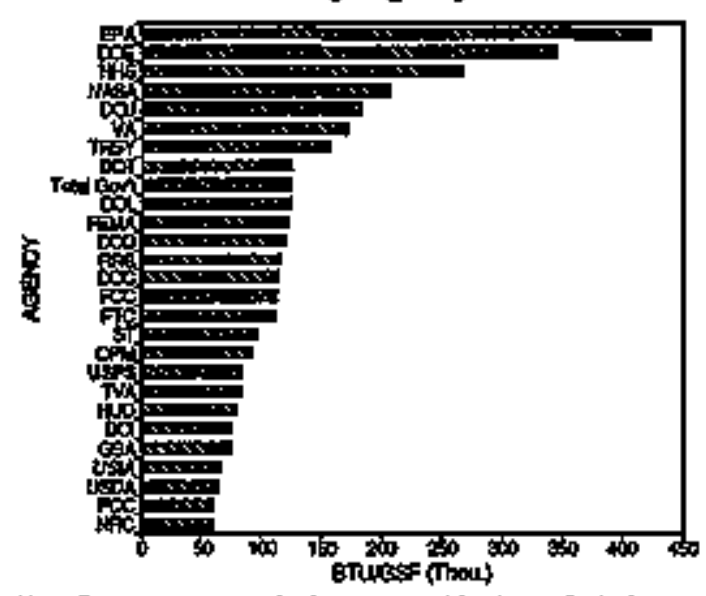

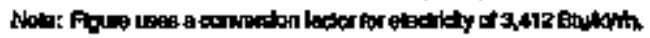
of rates of Baw/GSF among different agencies is a restlt of the varying missions of the agencies as well as their varying criteria for excluding energy intensive facilities.

\section{c. Federal Bullding Energy Performance Standards}

Federal agencies are subject to the provision of 10 CFR part 435 which sets forth interim building energy performance standards for new Federal buildings. These standarits were isstred under the Energy Conservation Standards in New Buildings Act of 1976, as amended, 42 U.S.C. 6831 et seq. In addition, Executive Order 12759 requires each agency to establish certification procedures to ensure that new Federal buildings are designed and consinucted to comply with the standards.

DOE, in response to the Energy Policy Act of 1992, has analyzed the Council of American Building Officials Model Energy Code, 1992 and 1993; the current Federal residential standard, and the codified version of the Amertcan Society of Heating, Refrigerating, and Air Conditioning Engineers' Standard 90.2-1993 (Standard 90.2-1993). Based on these continuing analyses, DOE expects to propose a Federal residential standard during fiscal year 1995 that utilizes the Model Energy Code format and that contains those economically justified and technologically feasible requirements that are part of the current Federal residential standard, the Model Energy Code, and the codified version of Standard 90.2-1993.

The existing Federal commercial standard currently has a format similar to Standard 90.1-1989 and has more rigorous criteria than the provisions of that standard. The main difference can be found in the lighting requirements area, with the existing Federal commercial standard having 
more stringent requirements. The Federal commercial code that will be published in the first quarter of FY 1995 is expected to be substantially similar to the current Federal commercial standard but in a codified form.

The proposed Federal residential and commercial energy-efficiency standards will be published in the Federal Register during FY 1995. The notices will also announce public hearings and a public comment period for interested parties to respond to the requirements of the standards.

Title V, subtitle $\mathbf{H}$, of the Energy Security Act requires certain Federal agencies to reach a consensus regarding factors and data used for developing energy conservation standards for residential, commencial, and agriculural buildings. The Department of Energy (DOE) has endeavored to fulfill these requirements by developing common energy conservation standarts for all new Federal buildings and by issuing life cycle costing procedures for use by Federal agencies in the assessment of energy conserving investments for buildings. DOE has also worked closely with HUD in coordinating the technical factors and data used to develop HUD's Manufactured Housing Standards and has committed to work closely with all Federal agencies to coortinate and upgrade the standaris applied by these agencies to non-Federal buildings. 


\section{ENERGY INTENSIVE OPERATIONS IN FEDERAL FACHITIES}

\section{A. Energy Consumption and Costs tor Energy Intensive Operations}

NECPA allows agencies to exclude from the buildings goal facilities which house energy intensive activities. The energy consumed in these facilities is reported under the category of excluded/process energy. The reporting of energy used in excluded buildings assures that total Federal energy consumption is monitored.

The designation of excluded buildings is at the discretion of each agency. Cunrenty, 14 agencies are excluding specific facilities from the NECPA goal: the Departments of Agriculture, Commerce, Defense, Energy, Justice, State, Transportation, and the Treasury, the General Services Administration, the National Aeronantics and Space Administration, the National Archives and Records Administration, the Panama Canal Commission, the Tennessee Valley Authority, and the U.S. Information Agency. Lists of the excluded buildings that have been identified by the agencies are included in Appendix $\mathbf{E}$.

Table 8 shows that fuels consumed by excluded/process energy have increased 132.2 percent compared to FY 1985 and 31.5 percent over FY 1993. Daring FY 1994, the Department of Defense consumed 39.8 trillion Bhu of excluded/process energy, 42.7 percent of all excluded/process energy used by the Federal Government. Some of the fluctuations in consumption of exclnded/process energy resulted from agencies changing data collection and reporting procedures. The large increase in reported energy in this category for FY 1994 is the result of the first-time reporting by TVA of electricity used in power plants for station service use. TVA electricity consumption comprised 25.9 percent of the energy used in this category. The Department of Justice also commenced reporting energy consumption in its excluded buildings during FY 1994. Increases in consumption of excluded/process energy compared to FY 1985 is also partially attributable to DoD's reallocation, beginning in the FY 1988 reporting year, of energy previously reported in the buildings category to the process category. Also contributing to this increase was the Treasury Department's initial reporting of process energy in FY 1991. Treasury neither reported process energy prior to 1991 nor revised its building energy consumption prior to 1990 to exclude process entergy. NASA began reporting process energy in FY 1989 and has revised its prior year data USIA also began reporting energy onder this category in FY 1989. USIA has not reported any process energy consomption for any prior years. GSA began reporting energy in excheded buildings in FY 1990 and has backed out this energy consumption from its FY 1985 buildings data. The Departments of Agriculture and Commence both began excluding buildings where energy intensive activities occur in FY 1992. USDA revised all of its prior year buildings data back to FY 1985 to reflect the exclusion of the Agricultural Research Service. The Commene Department nevised its FY 1985 base year data only to reflect the exclusion of its energy intense facilities. The State Department and NARA began reporting excluded/process.energy in FY 1993 and have not revised data for any prior years.

Energy used in energy intensive operations accounts for approximately 7.8 percent of the total 1.20 quads used by the Federal Government. Electricity conscitutes 62.4 percent of the energy used in energy intensive operations; 20.6 percent is accounted for by natural gas, 6.9 percent by 


\section{TABLE 8}

FEDERAL ENERGY CONSUMPTION IN EXCLUDED BUILDINGS/PROCESS OPERATIONS

(In Billions of British Thermal Units, Millions of Barrels of Oil Equivalent [MBOE], and Petajoules [Joule $\times 10^{15}$ ])

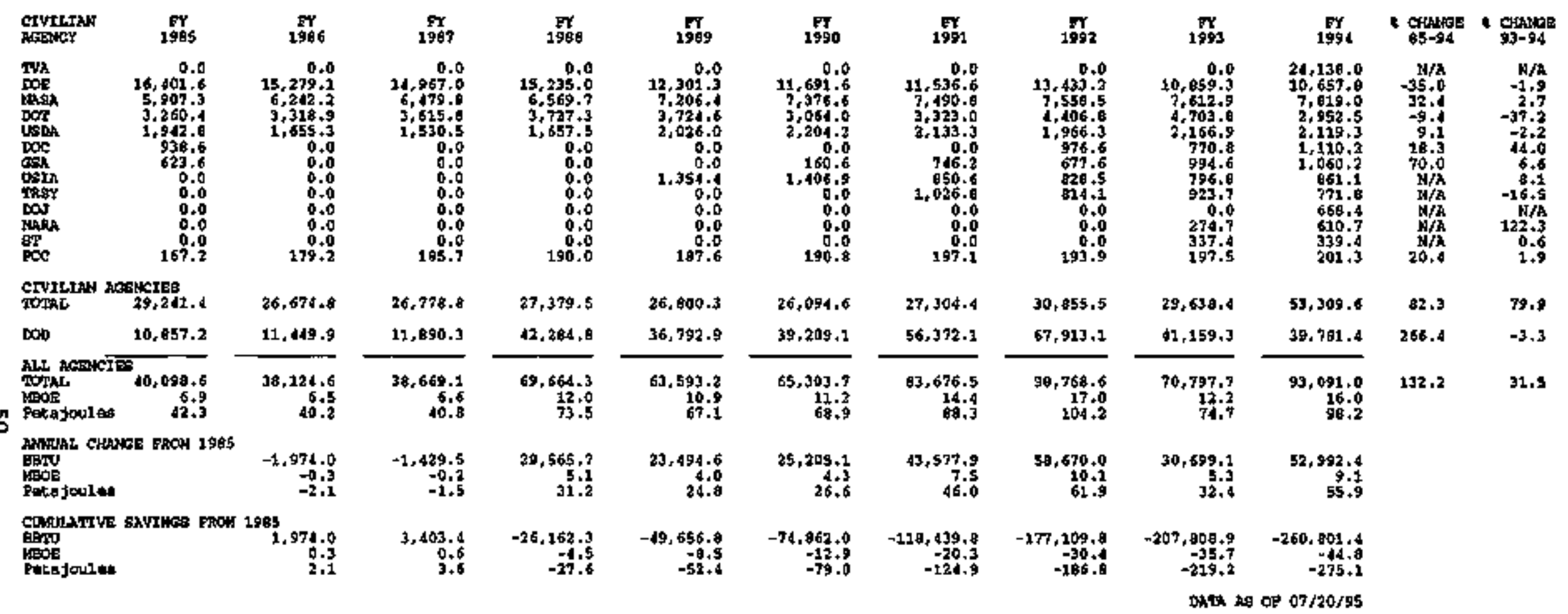

Notet Thls lable uses a conversion factor for electricly of 3,412 Asu per kitowath hom. Sum of components may not equal todal due to lodependem rounding

Source: Federal Agerxy Annual Energy Management Data Reports 
coal, and 7.2 percent by fuel oil. Small amounts of purchased steam, liquefied petroleum gas (LPG)/propane, and "other" energy account for the remaining 3.0 percent.

The energy used in energy intensive operations in FY 1994 accounted for approximately 12.I percent of the total Federal energy bill. Table 9 shows that the Federal Government spent approximately $\$ 975.3$ million for excluded/process energy during the fiscal year. The average cost for excluded/process energy in FY 1994 was $\$ 10.48$ per million Btu, up 22.7 percent from the average cost of $\$ 8.54$ reported in FY 1993 (see Appendix C).

\section{B. Statutory Background and Progress Toward Goals for Industrial Facilities}

Under section 543(a)(2) of NECPA, buildings that house energy-intensive activities may be excluded from NECPA's performance goal for buildings. These buildings are listed in Appendix E. Most energy used in excluded buildings is process energy. Process energy is consumed in industrial operations, certain R\&D activities, and in electronic-intensive facilities.

Executive Order 12759 expanded the scope of Federal energy management activities beyond the NECPA mandates by establishing goals for industrial operations. It required industrial facilities to increase energy efficiency by at least 20 percent by FY 2000 in compatison to FY 1985 to the extent that measures undertaken are cost-effective and minimize life-cycle costs. Executive Order 12902 changes this goal to require an increase in energy efficiency by at least 20 percent by 2005 as compared to 1990 . Measures undertaken to achieve this goal must be cost-effective, and agencies are also directed to implement all costeffective water conservation projects. The Executive Order goal applies to certain buildings currently excluded under NECPA where industrial operations are performed. During FY 1994, a working group of the Interagency Energy Management Task Force concentrated efforts on developing appropriate indicators for measuring performance under this goal.

The Department of Defense excludes two types of energy from the NBCPA performance goal: process energy and "cold iron" energy. Process energy is used in facilities that perform production or industrial functions. "Cold iron" energy is used to supply power to Navy ships docked in port. Both types of energy are included in this report under the category of excluded/process.

The Department of Energy reports its use of metered energy in extensive experimental research and production processes under excluded/process energy. The metened process energy used by DOE includes energy consumed in: prodaction nuclear reactors, industrial-type operations for weapons and nuclear fuel production, and research and development facilities such as experimental nuclear reactors and linear accelerators. Excluded/process energy totalled 10.7 trillion Bw in FY 1994, which represents 25.9 percent of all energy consumed by DOE. The use of excluded process energy by DOE in FY 1994 was 35.0 percent less than in FY 1985, and 1.9 percent less than FY 1993.

NASA excludes from the NECPA performance goal facilities which fall under its definition of mission-variable facilities. These highly specialized, energy-intensive facilities house space science experimental and testing activities, as well as some indastrial operations. Examples are 
TABLE 9

DEFENSE AND CIVILIAN FEDERAL COSTS FOR EXCLUDED BUILDINGS/PROCESS ENERGY IN FY 1994 (IN MILLIONS OF NOMINAL DOLLARS)

\begin{tabular}{|c|c|c|c|c|c|c|c|c|}
\hline & ELSECTRICITI & FUER ort & $\begin{array}{l}\text { NATJRAL } \\
\text { gas }\end{array}$ & $\begin{array}{l}\text { LPG/ } \\
\text { PAOPANE }\end{array}$ & COAT & $\begin{array}{c}\text { FUACHASED } \\
\text { STEA U }\end{array}$ & CTHER & TOTAL \\
\hline 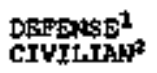 & $\begin{array}{l}200.129 \\
651.270\end{array}$ & $\begin{array}{l}14.939 \\
10.261\end{array}$ & $\begin{array}{l}36.796 \\
22.469\end{array}$ & $\begin{array}{l}0,166 \\
0.442\end{array}$ & $\begin{array}{r}10.554 \\
0.945\end{array}$ & $\begin{array}{l}6.518 \\
8+416\end{array}$ & $\begin{array}{l}3.675 \\
0.294\end{array}$ & $\begin{array}{r}361.177 \\
694.122\end{array}$ \\
\hline
\end{tabular}

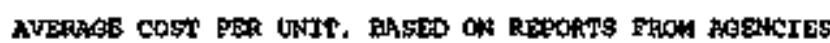

\begin{tabular}{|c|c|c|}
\hline 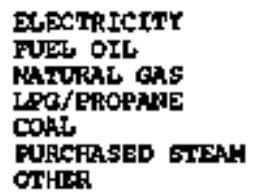 & $\begin{array}{r}50.51 \\
0.52 \\
3.20 \\
0.52 \\
4.22 \\
9.36 \\
3.91\end{array}$ & 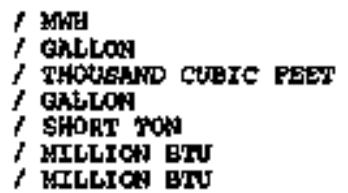 \\
\hline
\end{tabular}

DATA AS OF 07/20/95

in Includes DoD costs for process and cold inon energy.

${ }^{2}$ Includes DOE costs for metered process enerzy and energy costs for builtings excluded from performance measurement by DOC, DOJ, DOT, GSA, NASA, NARA, PCC, STATE, TRSY, TVA, USDA, and USIA.

Note: Sum of components may not equal total due to mbdependent munding.

Source: Annual energy cost data submitted to DOE by Federal agencies. 
wind tonnels driven by molti-thousand horsepower electric motors, launch facilities, space simulation chambers, space communication facilities, and research analysis centers.

The Department of Commerce excludes buildings operated by three of its agencies: the National Institute of Standards and Technology (NIST), the National Oreanic and Atmospheric Administration (NOAA), and the Burean of the Census. NST installations have been excluded because they are comprised of general purpose and special laboratories that require constant environmental space control and base electrical loads for scientific equipment and computer systems. NOAA Weather Service facilities operate 24 hours a day and consist of radar towers, computers, special garges, meters and other sophisticated equipment. Marine Fisheries and Laboratories conduct marine biology research and utilize refingerators, freezers, incubators, coolers, seawater pumps, and compressors that operate 24 hours a day. The Bureau of Census Charlote Computer Center is a leased facility and is used solely as a computer center. The building is operated 24 hours a day.

Within the Department of Transportation, the Federal Aviation Administration excludes all buildings involved in implementing the National Airspace System Plan. These buildings house energy-intensive electronic equipment with the associated HVAC requirements to maintain an environment for reliable equipment operation.

The U.S. Information Agency designates domestic and overseas Voice of America Relay Stations as energy-intensive facilities and reports this consumption as process energy excluded from the NECPA performance goal.

A substantial amount of the Panama Canal Commission energy consumption is dedicated to process functions, primarily comprising the locks, industrial, and other canal ancillary or support facilities.

The GSA excludes from the NECPA perfornance goal those buildings and facilities where energy usage is skewed significantly due to reasons such as: buildings entering or leaving the inventory during the year; buildings down-scaled operationally to prepare for disposal; buildings undergoing major renovation and/or major asbestos removal; or buildings functions like that of outside parking garages which conșume essentially only lighting energy, yet are classed as buildings. GSA's excluded beildings, due to these factors, could distort GSA's actul progress toward meeting the energy reduction goal.

Energy reported by the Treasury Department under the category of excluded/process energy is comprised mainly of industrial energy consumption by the Bureau of Engraving and Printing and the Mint.

The State Department excludes unique, special-use facilities with special security and operational requirements including the President's guest house, a computer facility, the Intemational Chancery Center, and the Main State Facility.

NARA designates all I2 of its facilities as energy intensive because of stringent records storage requirements which demand that documents and records be maintained in a controlled environment 24 hours per day, 365 days per year. 


\section{ENERGY MANAGEMENT IN VEHICLES AND EQUTPMENT}

\section{A. Energy Consumption and Costs for Vehicles and Equipment}

Vehicle and equipment energy consists of energy used by eguipment ranging in size and function from aircraft carriers to forklifts. It includes aircraft and naval fuels, automotive gasoline consumed by Federally-owned and leased vehicles and privately-owned vehicles used for official business, and the energy used in Federal construction.

Table 10 shows that in FY 1994, the Federal Government used approximately 722.9 trillion Bm of energy for vehicles and equipment, a decrease of 22.7 percent relative to FY 1985 . DoD's vehicle and equipment energy consumption decreased 24.3 percent from FY 1985, while the civilian agencies increased consumption by 10.0 percent. Overall, vehicle and equipment consamption decreased 6.6 percent from FY 1993. Federal energy consumption in vehicles and equipment is at its lowest level since Federal agencies began seporting consumption in 1975. This is mainly attributable to decreased operations by the Deparment of Defense.

Jet fuel consumption accounted for 76.2 percent of alt vehicle and equipment energy in FY 1994. In FY 1994 compared to the previous year, jet fuel consumption decreased 10.1 percent from 612.4 triblion Btu to 550.7 trillion Btu.

Agencies have taken many tangible steps to keep the use of vehicle fuels to a minimum. For example, USPS continues to modernize its fleet, adding diesel delivery vans and long-life vehicles to its inventory, both of which are more fuel efficient than the older vehicles they replaced. DoD continues to increase the use of flight simulators, as well as the use of new propulsion technologies in order to lessen the growth of vehicle and equipment fuel consumption.

Increased mission activities accounted for higher levels of operations energy use by some agencies. The Commerce Department's significant increase in consumption during FY 1990 was due primarily to increased miles driven by Census personnel in conducting the 1990 Census. Energy consumption in DOC's vehicles has declined by 67.9 percent in FY 1994 from FY 1990.

Other fluctuations in consumption of vehicle fuels reselted from changes in data collection and reporting procedures. The significant decrease in vehicular fuel consumption compared to FY 1985 reported by the Department of Health and Human Services is the result of data collection difficulties which omilted from their reports fuel consumed by leased velicles and privately-owned vehicles authorized for Government service after FY 1987. HHS reported no vehicles under the agency's control during FY 1990, FY 1991, and FY 1992. 
TABLE 10

FEDERAL ENERGY CONSUMPTTON IN VEHICLE AND EQUTPMENT OPERATIONS

(In Billions of British Thermal Units, Millions of Barrels of Oil Equivalent [MBOE], and Petajoules [Joule $\mathrm{x} 10^{\text {t5 }}$ )

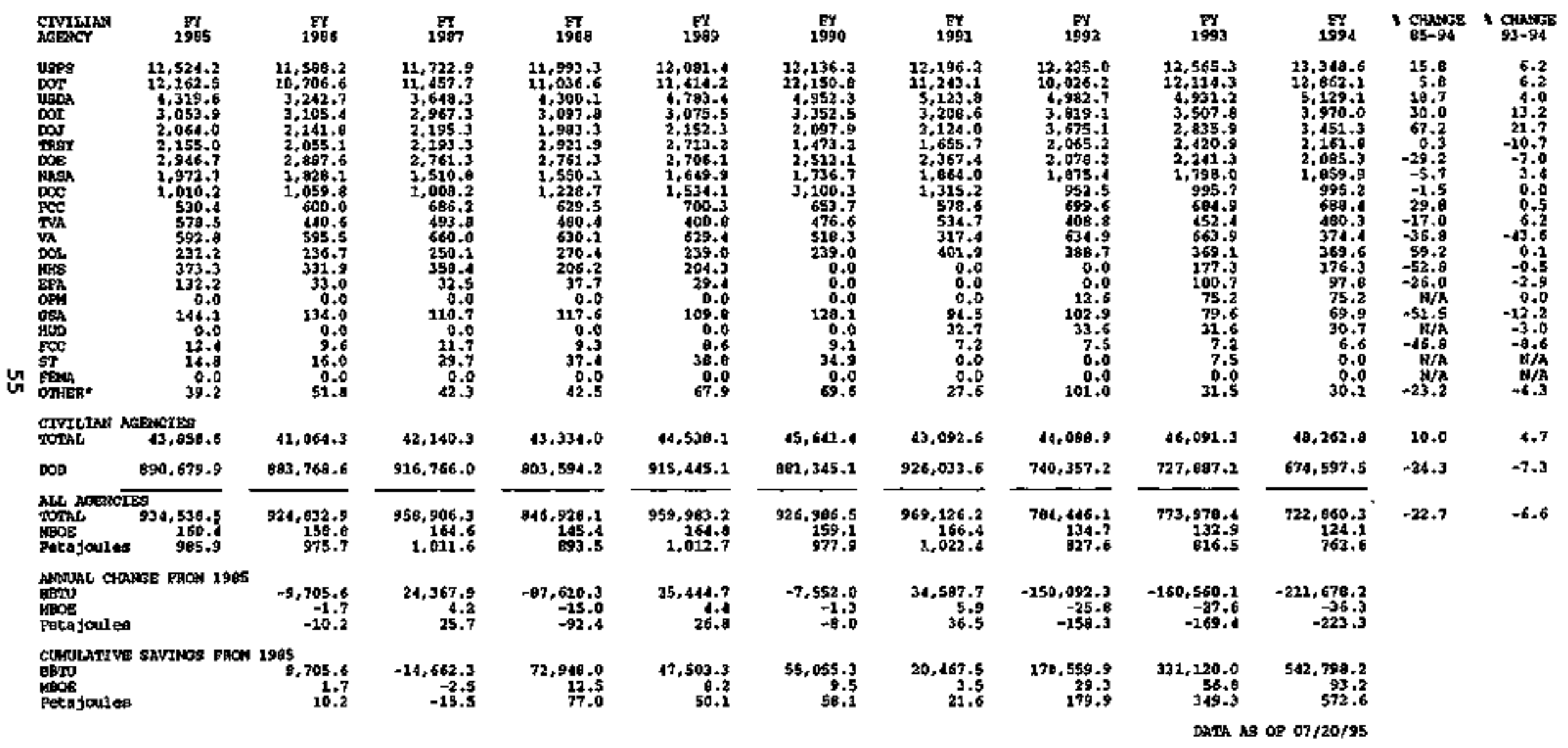

"Olher includes for certain years the Commodity Futures Trading Commission, Department of Housiog and Urban Devekpment, Nalionat Sctence Fonndafion, Nuclear Regulatory Comunission, Office of Personnel Mangenement, and the U.S. Infomation Agetcy.

Note: FY 1994 contains estimated data for the following agency: Office of Persounel Management. Sum of components may not equal total sue to tndependent rounding.

Sioure: $\quad$ Federal Ageticy Annual Energy Management Data Reports 
Figure 9 depicts the vehicles and equipment fuel mix within $\mathrm{DOD}$ and civiltan agencies. Jet fuel accounts for 550.7 trillion Bto or 76,2 percent of the total energy usage in the category, with 18.8 percent attributed to diesel and distillate fuel, 4.1 percent to anto gasoline, and 0.9 percent to aviation gasoline, navy special, LFOtpropane and other fuels, combined

As shown in Tables 11-A and 11-B, the Federal Government spent $\$ 3,251.9$ million on vehicles and equipment energy in FY I994, 26.6 percent less than the FY 1993 expenditure of $\$ 4,430.4$ million in nominal dollars. In FY 1994, the average price for all types of vehicles and equipment energy was $\$ 4.50$ per million Btu, down 21.4 percent from the $\$ 5.72$ reported in FY 1993. The average cost of gasoline to the Federal Government decreased 3.9 percent from $\$ 1.03$ per gallon in FY 1993 to $\$ 0.99$ per gallon in FY 1994. The unit costs for diesel/distillate fuel and jet fuel decreased 9.5 percent and 24.1 percent respectively. Lower unit costs combined with decreased consumption pushed the cost of vehicles and equipment fuels below the cost of buildings and facility energy for the firss time in the Federal Govemment.

When compared to FY 1985 using constant 1987 dollars, energy costs for vehicles and equipment decreased 59.8 percent from $\$ 6,417.5$ million to $\$ 2,578.8$ million in FY 1994 . During that sime period, the Govermment's average cast for vehicles and equipment energy, in constant dollars, fell 48.0 percent from $\$ 6.87$ per million Btu to $\$ 3.57$ per million $B$ m.

Vehicle and equipment fuel costs in FY 1994 represent 40.4 percent of the Government's total energy costs of $\$ 8.0$ billion.

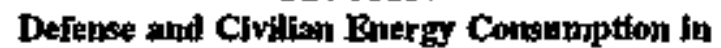
Vehicles and Equpintent by Fuel Type, FY 1984

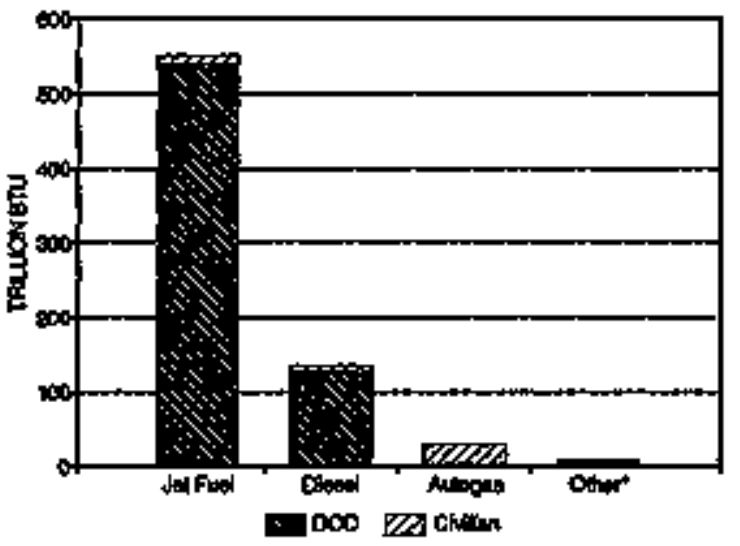

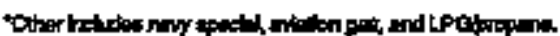


TABLE 11-A

DEFENSE AND CIVILIAN FEDERAL COSTS FOR VEHCLLSS AND EQUIPMENT ENERGY IN FY 1994

(IN MILLIONS OF NOMINAL DOLLARS)

\begin{tabular}{|c|c|c|c|c|c|c|c|c|}
\hline $\begin{array}{l}\text { DERPNGE } \\
\text { CIVILIAN }\end{array}$ & $\begin{array}{l}\text { AUTO GKS } \\
20.137 \\
213.949\end{array}$ & $\begin{array}{r}\text { DIESEL } \\
\text { 519. } 061 \\
\text { S0.220 }\end{array}$ & $\begin{array}{c}\text { IPG/ } \\
\text { PEDPANE } \\
0.000 \\
0.199\end{array}$ & $\begin{array}{c}\text { AVIATION } \\
\text { gAs } \\
0.106 \\
5.59 B\end{array}$ & $\begin{array}{r}\text { JET FUE } \\
2.356 .091 \\
68.424\end{array}$ & $\begin{array}{c}\text { MAVY } \\
\text { SEECIN. } \\
\text { 4.695 } \\
0.000\end{array}$ & $\begin{array}{r}\text { OTHER } \\
0.000 \\
13.226\end{array}$ & $\begin{array}{l}\text { TOTAL } \\
2,900,280 \\
351.607\end{array}$ \\
\hline & 234.086 & 569.291 & 0.189 , & $5.70 d$ & $2,424,515$ & 4.005 & 13.236 & $3,251.687$ \\
\hline
\end{tabular}

AVERAGE COST PPR UNIT, RASED CN REPOHTS FRON AGRACIRS

VEHTCIES AND DQUTFIBY

\begin{tabular}{|c|c|c|c|}
\hline 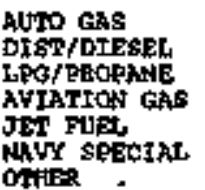 & & $\begin{array}{l}0.99 \\
0.58 \\
0.58 \\
1.19 \\
0.57 \\
0.32 \\
3.50\end{array}$ & 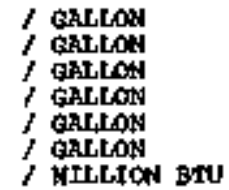 \\
\hline
\end{tabular}

Note: Conlains estimated data for the following agency: Office of Prusonnel Management.

Sum of components may not equal tolat dus wo independent rounding.

Source: Federal Agency Amual Energy Management Data Reporis 
TABLE 11-B

CONSUMPTHON AND COSTS OF VEHICLES AND EQUIPMENT ENERGY BY FUEL TYPE IN FY 1994, FY 1993, AND FY 1985 (NOMDNAL DOLLARS)

FY 1994

ENERQY TYPE

BIfuIONS OF
Erus

COST PER MILLION
BTUs

COST IIN HILLIONS

AUFO GASOEING

DIST/DIBSEL

LPG/PROPANIE

AVIATION GASOLINE

JET FUES.

NAYY SPECIAI

OTHER

$29,635+0$

$135,9 \mathrm{g0}+5$

$31+1$

$600+9$

$550,732+9$

$2,097+1$

$3,782+8$

TOTAY

$722,860,3$

7.8990

4.1065

6.01873

9.4932

4.4023

2.3294

3.4965

OF DOLLARS)

AVERKGE COSI PER UETV = \$ 4.499

FY 1993

ENEROY TYPE

BIf.jIONS OF BTU;

AUIO GASOLINE
DISTIDIESEL
LPG/PROPANE
AVIATION GASOLINE
JET FUEL
WAYY SFECIAI
OTHER
TOTAL.

$34,433,9$

$124,298.0$

18.

$658+2$

$612,366.2$

$10+\mathrm{B}$

$2,142,4$

$773,978+4$

COSI PER NILLION

BTHs

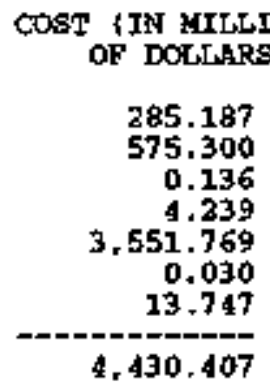

AVERAGE COST PER METU = \$ 5.724

FY 1985

ENERGY TYPE

\section{ETLITOAs of BTIS}

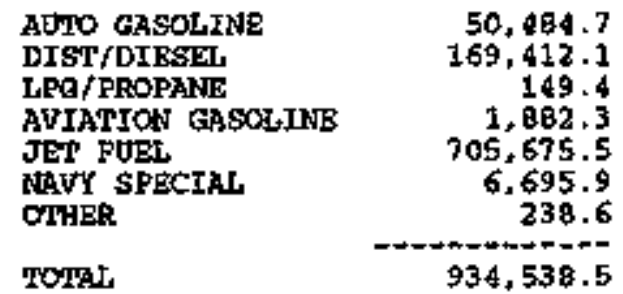

8. 3702

4.6264

7.3140

6.4394

5. 0001

2.7397

6.4168

COST PER MILLION BTV's

$$
\begin{array}{r}
7.5598 \\
6.0247 \\
7.0069 \\
11.9489 \\
6.5094 \\
5.5064 \\
5.3939
\end{array}
$$

COST (IN MILIONS OF DOLIARS)

381.655

$1,020.655$

1.047

22.491

4.593 .559

37.419

1.28?

$6,058.113$

AVERAGE COST PER UENU $=\$ 6.482$

DATh AS OF $07 / 22 / 95$

Note: FY 1994 contains estimated data for the following agency: Office of Personned Minngement. Sum of components may not equal totit due to independent rownding.

Sourcer: Federal Agency Amual Energy Managemeut Data Reports 


\section{B. Progress Toward the Reduction Goals for Gasoline and Diesel Consumption}

Section 10 of Executive Otder 12759 establishes an energy-efficiency goal for Federal vehicles. Each agency operating at least 300 conmercially designed motor vehicles domestically is directed to develop a plan to reduce gasoline and tiesel consumption by ten percent by FY 1995 in comparison to FY 1991. GSA, in consultation with DOE, issued guidance on October 14, 1992, to assist agencies in meeting this goal.

Table 12 shows Federal agency progress in FY 1994 in meeting the goals of section 10. Of the agencies reporting gasoline consumption, the level of consumption overall decreased 12.9 percent from 272.2 million gallons in FY 1991 to 237.1 million gallons in FY 1994.

Of the agencies reporting consumption of diesel fuel, the overall level of consumption decreased 14.7 percent from 1,150.0 million gallons in FY 1991 to 980.4 million gallons in FY 1994. DoD's 14.4 percent decrease in diesel consumption is the main contributing factor in this decrease. The high level of diesel consumption by DoD during FY 1991 is attributed to Desert Shield/Desert Storm operations. Diesel consumption data may include other types of off-road vehicles and equipment, in addition to on-road passenger cars and trucks.

Section 11 of the Executive Order establishes requirements for the acquisition of altemative fuel motor vehicles by the end of model year 1995. Agencies electing to use these vehicles receive credit toward meeting the vehicle energy efficiency goal. Information on Federal Government activities related to altemative fuel vehicles is included in the next section of this report.

TABLE 12

FEDERAL AGENCY PROGRESS TOWARD THE GOALS OF SECTION 10 OF EXECUTIVE ORDER 12759, FY 1991 and FY 1994

\begin{tabular}{|c|c|c|c|c|c|c|c|}
\hline \multicolumn{8}{|c|}{ DIESTI CONEWHPTION } \\
\hline AGENCY & 1991 & 1994 & 4 CHANOE & AGEACY & 1991 & 1994 & * chthuse \\
\hline 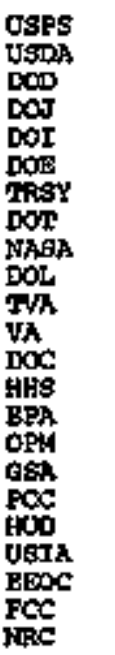 & $\begin{array}{r}72,152.0 \\
37,949.6 \\
95,958.0 \\
14,260.1 \\
17,934.8 \\
9,594.9 \\
5,666.7 \\
5,591.2 \\
2,576.0 \\
3,215.0 \\
3,234.0 \\
2,094.0 \\
2,525.0 \\
0.0 \\
0.0 \\
0.0 \\
756.2 \\
335.9 \\
261.5 \\
90.1 \\
0.0 \\
55.8 \\
35.5\end{array}$ & $\begin{array}{r}89,257.6 \\
36,905.1 \\
34,692.0 \\
19,760.7 \\
26,771.5 \\
9,495.5 \\
7,721.4 \\
5,006.1 \\
3,274.0 \\
2,955.5 \\
2,775.9 \\
2,465.0 \\
2,143.0 \\
1,394.3 \\
724.8 \\
601.7 \\
559.2 \\
246.0 \\
213.0 \\
93.6 \\
61.2 \\
51.8 \\
20.2\end{array}$ & $\begin{array}{r}23.7 \\
-3.0 \\
-63.8 \\
38.6 \\
-5.0 \\
10.5 \\
36.3 \\
-10.5 \\
27.1 \\
-8.1 \\
24.3 \\
17.7 \\
-15.1 \\
N / A \\
N / A \\
N / A \\
-26.1 \\
-26.8 \\
-16.5 \\
3.9 \\
5 / 4 \\
-7.2 \\
-43.1\end{array}$ & 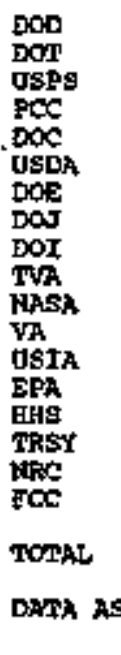 & $\begin{array}{r}3.073,084.0 \\
30,390.7 \\
22,907.0 \\
3,869.0 \\
6,637.1 \\
2,201.7 \\
5,601.3 \\
775.2 \\
1,514.2 \\
1,791.0 \\
644.0 \\
601.0 \\
61.5 \\
0.0 \\
0.0 \\
51.8 \\
1.2 \\
1.7\end{array}$ & $\begin{array}{r}918.289 .0 \\
27.575 .9 \\
15.799 .5 \\
4.741 .3 \\
4.737 .0 \\
2.305 .0 \\
2.056 .9 \\
1.560 .8 \\
1,195.9 \\
686.8 \\
627.0 \\
479.0 \\
55.9 \\
38.9 \\
22.9 \\
20.0 \\
1.9 \\
1.0\end{array}$ & $\begin{array}{r}-14.4 \\
-9.3 \\
-31.0 \\
22.5 \\
-29.6 \\
4.7 \\
-63.3 \\
101.3 \\
-21.0 \\
-50.5 \\
-3.6 \\
19.2 \\
-31.4 \\
4 / 2 \\
1 / 4 \\
-57.6 \\
58.3 \\
-41.2 \\
-14.7\end{array}$ \\
\hline Torre & $272,189.7$ & $237,080.0$ & -12.9 & & & & \\
\hline
\end{tabular}

Note: FY 1994 contains estimated data for the following ageocy. Office of Personnel Management.

Sum of componests may tot equal total to to tidependent rounding.

Source: Federal Agency Anntal Energy Management Data Repcrss 


\section{Alternative Fuel Vehicles}

Alternative fuel vehicles (AFV) are designated and manufactured by an original equipment manufacturer or converted to operate as either a bi-fuel, flexible fuel, or dedicated vehicle. A bi-fuel vehicle has the ability to operate on either an alternative fuel or gasoline, whereas a flexible foel vehiche has the ability to operate on a mixture of altemative fuel and petroleunbased fuels. Dedicated vehicles are designed to operate only on altemative fued. The alternative foels currently used by Federal agencies are: M-85 (85 percent methanol, 15 percent gasoline), E-85 (85 percent ethanol, 15 percent gasoline), CNG (compressed natural gas), LNG (liquified natural gas), LPG (liquified petroleum gas), and electricity.

Sections 301 to 311 of Title III of EPACT contain provtsions affecting Federal fleets. These sections of EPACT expand and confurm the activities and goals of section 11 of Executive Order 12759. Executive Order 12759, section 11, requires that the Federal Government acquire the maximum number practicable of AFVs. To meet the requirements of Executive Order 12759, each FederaI agency has developed a 5-year plan for introducing AFVs into its fleet. Section 303 of EPAct mandates the fleet requirements for new acguisitions to the Federal Fleet listed in the first column of the following table. With the Executive Order 12844 of April 21, 1994, the President has established even more aggressive goals for increased AFV usage. Under this Execulive Order, each agency should exceed EPACT requirements by 50 percent for FY 1993 to 1995. The targets for Federal fleets under this orter are listed below.

AFV Requirements for New Acquisitions in Federal Fleet

\begin{tabular}{||l|c|c|}
\hline & EPACT & Executive Order 12844 \\
\hline FY 1993 & 5,000 & 7,500 \\
\hline FY 1994 & 7,500 & 11,250 \\
\hline FY 1995 & 10,000 & 15,000 \\
\hline FY 1996 & $12,500^{14}$ & 35 percent $^{15}$ \\
\hline FY 1997 & $16,667^{15}$ & 40 percent $^{15}$ \\
\hline
\end{tabular}

Section 308 of Title III of EPACT requires agencies to measure the aggregate percentage of alternative fivel use in bi-fivel vehicles in their fleets. The Department of Energy, in cooperation with other Federal agencies, has revised the Annual Energy Management Data Report to include a section to report the number of alternative fuel vehicles in each agency's fleet and the alternative fuel used in these vehicles. This information will be collected for both dedicated and

14 These figures based on DOE/CE-0362P. Section 303 of the EPACT states that 25 percent of all new acgaisitions in 1996 must be AFVs.

TOOE estimates.

16 This target based on DOE/CE-0362P. Section 303 of EPAct states that 33 percent of all new acquisitions in 1997 must be AFYs. 
bi-fuel AFVs. The collection of the above information will begin with the FY 1995 report on Federal Government Erergy Management and Conservation Programs.

Through its Interagency Fleet Management System (IFMS) and the Automotive Commodity Center, the General Services Administration plays a key role in the implementation of AFV legislation. GSA provides vehicles and support services to other Federal agencies through the IFMS. The IFMS accounts for approximately 25 percent of the total Federally owned inventory of 550,000 vehicles. During FY 1994, GSA procured 3,931 AFVs for the IFMS; the types and models of these are shown below. This brings the total AFVs procured for IFMS from FY 1991 through FY 1994 to 10,250. Direct AFV parchases by the Departments of Defense, Energy, Commerce, the Interior, and Agriculture accounted for 132 additional vehicles. In FY 1994, AFV purchases totalled 4,063 vehicles.

FY 1994 New Agency Vehticle Assignments by Vehtcle Type (GSA Assigned)

\begin{tabular}{|l|l|c||}
\hline \hline \multicolumn{1}{|c|}{ MAKE and MODEL } & \multicolumn{1}{|c||}{ FUEL } & $\begin{array}{c}\text { NUMBER } \\
\text { PURCHASED }\end{array}$ \\
\hline Dodge Spirit Compact Sedan & M85 Flexible Futel & 3,555 \\
\hline Ford Taurus Mid-Size Sedan & M85 Flexible Fuel & 64. \\
\hline Ford Taurus Mid-Size Sedan & E85 Flexible Fuel & 25 \\
\hline Dodge B250 8-Passenger Van & CNG Dedicated & 105 \\
\hline Dodge B250 Cargo Van & CNG Dedicated & 37 \\
\hline Dodge Caravan (Mini-van) & CNG Dedicated & 120 \\
\hline Chevrolet Half-Ton Pickup Truck & CNG Bi-Furel & 25 \\
\hline
\end{tabular}

Also within GSA is the Automotive Commodity Center, which is the central source for establishing Federal contracts with manufacturess for the purchase of vehicles. The Center handles the acquisition of all light and medium daty vehicles for all Federal agencies, including the IFMS. The Center, as part of its effort under the Alternative Motor Fuels Act (AMFA), developed specifications and procurement descriptions for the acquisition of AFVs with original equipment manufacturers (OEM).

The U.S. Postal Service continues to operate the largest CNG fleet in the country. In FY 1994, the Postal Service converted over 1,000 delivery vehicles to operate on CNG. The Postal Service now has 1,663 vehicles operating on CNG. The Postal Service received eight methanol vehicles in FY 1994 and has ordered five ethanol vehicles.

The Department of Energy has made efforts to provide the private and public sector with information on issues concerning AFVs. An Alternative Fuels Hotline (1-800-423-1DOE) was established in June 1992 to provide callers from Federal agencies, industry and the public with answers to questions on AFVs. By calling the toll free number, callers can request information on AFVs. In 1994, 7,346 calls were received. Most callets had questions concerning 
conversions, especially vehicle converstions to AFVs, EPACT and Clean Air Act requirements, and tax incentives.

The public may also access the Alternative Fuels Data Center (AFDC), which is located at the National Renewable Energy Laboratory (NREL) in Golden, Colorado. The AFDC is the central repository for data from DOE's altermative fuel vehicle demonstration programs. The AFDC stores data on demonstration programs that receive funding support anthorized by the AMFA of 1988. Information collected and provided by the AFDC includes:

- data on 600 government fleet vehicles;

- refueling site information for CNG, LPG, Ethanol, and Methanol;

- information on emissions, mileage, fuel economy;

- information on emissions, for flexible fuel vehicles running on alcohol fuels and gasoline;

- repair and maintenance logs of alternative fuel fleet vehicles;

- heavy duty and transit bus data for performance, emissions, fuel economy, and mileage;

- data on the Clean Fleet Program - run by Federal Express and South Coast Air Quality Management District (a study on five fuels).

Federal efforts to expand deployment of AFVs were boosted by the new Clean Cities Program. The Clean Cities Program, initiated by the DOE in September 1993, is a voluntary program designed to encourage fleet vehicle conversion to alternative fuel use while providing refueling and maintenance facilities for their operations. It encourages partmerships between fuel suppliers, vehicle manufacturers, consumers, fleet managers, utilities, environmental groups and Federal, state, and local government agencies. DOE supports Clean Cities participants through the placement of Federal vehicles and by maintaging two national hotlines and ten regional support offices. The Secretary of Energy made a commitment to enroll 25 Clean Cities by the end of calendar year 1994. This goal was surpassed and a total of 34 communities had been designated Clean Cities. DOE has established a number to handle inquiries from communities interested in joining the program: 1-800-CCITIES.

\section{The Administrative Fleet}

In August 1982, Executive Order 12375 set forth guidance for fuel efficiency standards for antomobiles acquired by Federal agencies in accordance with the Motor Vehicle Information and Cost Savings Act, 15 U.S.C. \$ 2001-2012. The fuel efficiency standard for passenger vehicles (sedans and wagons) acquired in FY 1994 was $27.5 \mathrm{mpg}$. For nonpassenger vehicles acquired in FY 1994, the standard for light tnxks was $20.5 \mathrm{mpg}$. The General Services Administration reports that the 17,796 passenger vehicles acguired by the Federal Govemment in FY 1994 achieved an average of $27.7 \mathrm{mpg}$, while the 19,970 newly-acquired light trucks achieved an average of $20.6 \mathrm{mpg}$. Vehicles designed for use in law enforcement, emergency rescue, and combat related missions are exempt from the fuel efficiency' requirements. 


\section{FEDERAL AGENCY ENERGY MANAGEMENT ACTIVITIES}

\section{DEPARTMENT OF AGRICULTURE}

Energy Efriciency Performance and

Implementation Stratejles

In FY 1994, the United States Depantment of Agricultime reported a decrease of 10.4 percent in Bal per gross square foot compared to FY 1985.

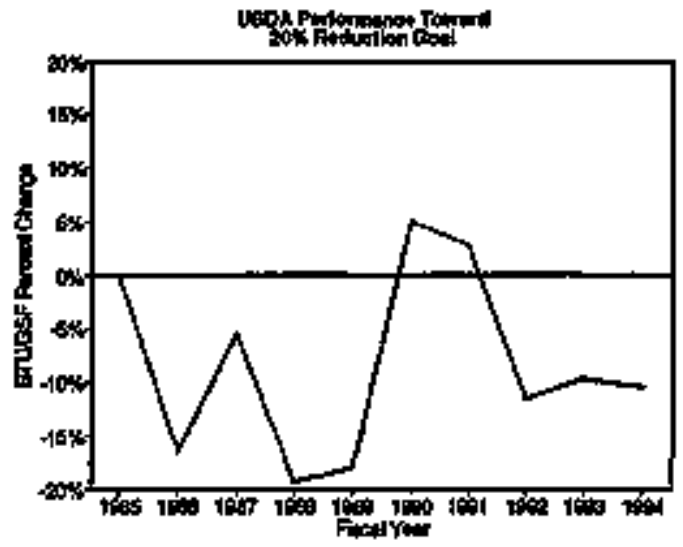

The USDA Exergy Mandgement Plan was revised to incorposate the requirements of Executive Order 12759 and was submitued to DOE in July 1992. Aloo in July 1992, the Plan was formally issned to USDA agency heads for implementation. Components of the strategy include increasing acclpant awareaess, properly maintaiming builfiug envelope and systems, implemensing no-cost and kow-cost energy conservation actions, and using energy-saving builditg operation procedares, In Jally 1994, the Agricnthure Research Service (ARS) held a four-day energy confenence and a task fonce developed an updated ARS Energy Management Plan. USDA is planning issuance of a new USDA Plan in June 1995.

Strating in FY 1994 and continaing intoFY 1995, USDA is working to conduct a prioritization survey and to begin comprehentsive andits of tumeryus facilities over 10,000 square feet. DOE's SAVEnergy andit program was requested in March 1994 to help conduct autits of numerous USDA facilities, including Forest Service (FS), ARS, Animal atb Plant Healh Inspection Service, and Soil Comservation Service (SCS) facilities. DOE reached an agreement with FS to conduct andits of 13 FS facilities in FY 1994, and more are expected to FY 1995.

\section{Training}

In FY 1994, agencies report that 88 employees received erergy management iraining at a cost of about $\$ 20,000$.
Funding

USDA agencies and the Offyce of Operations (OO) expended about \$7,3 million on energy conservation impsovements in FY 1994, excleniling surveys. USDA implentented namerous energy conservation actons, such as roof and wall insulation, converting furnaces to natural gas, installing high effictency fluorescent tobes and solid state ballasts, canlking, steam system repairs, motion sensor light switches, and repairs of HVAC equipment and systems under operations and minintennace activities. Examples of projects funded in FY 1994 include the Pollowing:

- Thermid Storage System, Sub-Central Plant (OO)

- Replace Court 3 Windows, South Buikting ( $\infty$ )

- Energy Efficient Lights, Phase I, South Buifding (OO)

- Replace Court 6 Whindows, Soath Building (OO)

- Replace Chiller No. 3, Ames, IA (ARS)

- Emergency Generator, Fargo, ND (ARS)

- Upgrade HVAC, Mandan, ND (ARS)

- Renovate HVAC and Boiler, Stonevilie, MS (ARS)

- Insulate Main Buildlng, Byron, GA (ARS)

- Solar Panels and Solar-Powered Punp, Beaveriead National Forest (FS)

- Energy Efficient Lights, Gallatin National Forest (FS)

- Replace Oil Fumaces with Gas, Lewis snd Clark National Forest (FS)

- Replace (16) Windows with Thernal Windows, Apache-Siggreaves National Forest (FS)

Energy Savings Performance Contracts USDA conducled studies in FY 1993 toconsider viable ESPC projects. In FY 1993, the Office of Operations conducted a study to determine the viability of constructing a chilled water plant (estimated cost $\$ 10$ million) to serve the Headquarters Conplex inder an 
ESPC contract This poject is being considered further in FY 1995.

Demand side Manngement

The Oftice of Operations is obtainting rebates from the Potomac Electric Power Company for lighting retrofits in the South Agricultuse and Aduninistration Builtings, as well as for a new thermal storage system. The simplest method of receiving rebates has been found to be as a credit on the vtility bills. The USDA Plan encourages all USDA agencies to use DSM services, ESPCs, rebates, and incentives offered by utilities and other private sector energy services providers. USDA agencies report difficulties relating to the small size of some facilities, lack of utility DSM programs available, and lack of tecknical manpower to manage such efforts.

\section{Vebicles}

The Department's altemative fiel vehicle (AFV) procurement plan aggressively proposes acquiring bundreds more AFVs, as funding and wehicle availability permit Between FY 1993 and 1995, USDA has acquired approximately 155 AFVs. This totil includes acquiring original equipanent manufactured vericles and contverting existing tleet webicles. Alternative fuel types include E-85 and M-85 flexible fuel sedprn, dedicated and th-fuel compressed natural gas (CNG) trucks and vans, and a number of converted LPG trucks. USDA published and distributed a directory of 3,500 service slations that sell ethanol-blended gasoline.

The Department's Agriculture Property Management Regulations instruct agencies to implement vehicle sharing prograns with co-locted, and closely situated ageacies and activities in the field. The objectives of this program are to maximize vekicle urilization and to reduce associated cost and fuel consumption tirough vehicle poolting and sharing. The regutations also require operators to perform rowtine energy-saving tasks: inspect vehicles annually, follow the manutacture's recommenied matrotenauce schedule, check tire inflations, and obey posted speed limits.

The Department of Agriculture is in the process of developing a Department-wide energy conservalion and alhernative fuel use outreach program. This program will foclude issuance of fact cards, to be placed in the vehicle, to remind operators of energy conservation measures, such as removal of mnecessary wetght ftom truck beds and tronks, proper inflation of tires to manufacturex's recommented levels on the tire sidewall, and preventive maintenance. The program will also emphasize the need for asquisition of alternative fuel veticles to adbere to the requitemeats of the Execntivo Orders and EPACT.
Envirenmental Activities Under the Oftice of Operations design and construction program, older chillers are being replaced wilh energyefiltcient non-CFC chilless, air handling systems are being cleaned and modifled to improve energy efficiencies and intoor ait quality, and PCB-contaminated light fixhures are being replaced will entergy-efficient lightick.

Energy Matrigement Contact Mr. Walter D. Aughenbaugh, PE. Chief, Engineering Branch

Facilities Mamagement Division Office of Operations, Room \$.313 U.S. Department of Agriculture 14th and Independence Avenue, SW Wastington, DC 20250

Ptone: 202-720-2804

Fax: 202-720-5019 


\section{DEPARTMENT OB COMMERCE}

Buergy Efficiency Performance and

Inplementation Strategies

In FY 1994, the Departinent of Commerce reported an increase in boildings energy consumption of 18.3 percent in buildings energy consumption in Btu per gross square foot compared to FY 1985.

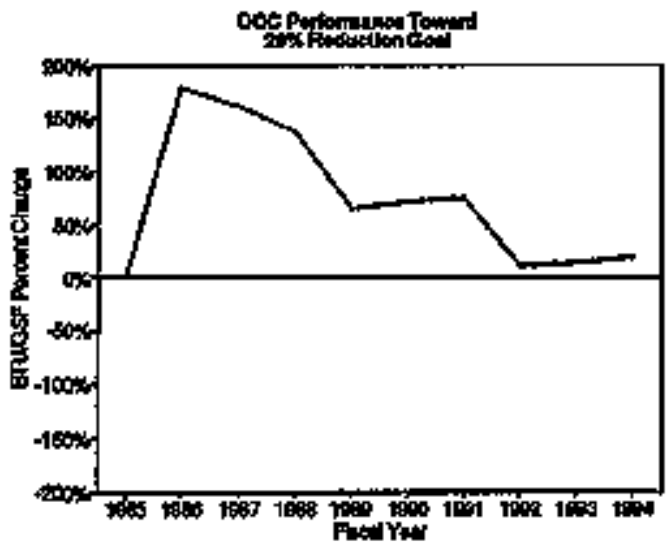

The Deparment of Commere ts clrculating for clearance a Department Administratlve Order on Federal Enercy Management. Thls document assigas responsibitities and provides program guidance on DOC's energy management program. Strategies include:

- Establishi a program to comply witb all Public Laws, Execuxive Orders, and Federal regukdions contotening energy and water mansigenent and be use of renewable energy sources.

- Implement a Federal energy and water mandigement program to reduce consumption and costs and achieve efficiency gaals for bolkdings, facilities, and vehicles.

- Ensare that an new DOC-constructed buildings are designed and built in accordance with applicable energy performance standards.

- Use life-cycle costing methodology in all procurement decisions in the acquisition of energy efficient goods and services including retroffts, new building design, new building systems and the selection of leased buildings.

- Perform enerpy surveys on all buildings as funds and programs allow.

- Promote energy conservation through employee traiting and awareness outreacb programs.
Activities at the Commerce Deparment bureaus sild sub-agencie's are identified below.

The nalure of laboratory operations and required envirommental conditions make the National Institute of Standaris and Technology (NIST) av entrgy intensive facillty and thereby exempt from meeting the goals in section 543(a)(2) of NECPA, as anendid. In coder th define specific energy reduction goals for the NIST facility. NIST plans to hire an energy conservation consultim to ansilyze the existing site conditions, determine realistic tong-term goals, and recommend fulture conservation projects. NIST"'s immediate goal is to devekop a comprebentive program to promote etlergy efficiency and reduce per square meter opersing cost, through profitable investonents and an energy saving performance contract, to the lowrest practical tevels. NIST contipues to make every effort to ensure the most efficient operation of NIST bulldings and equipurent.

Development of a Slte Utlities Master Plan includes a comprebensive site anglysis to provide NIST with detailed energy conservation goals, cost-effective recontmendations, and a technical plan and timeline for project insplementation. The amalysis will incomporate all possible variables, including: occupancy, energy bills, mimintenance, cast/bentefit and life-cycle utility robites, equipment performiance data, project cost and finarcing alteruatives, changing utility rates, environmental issures and confort Pojects will a simple payback period of less than 1 year may be funded by the NIST Facilities budget I arger projects will be used to develop the besis for an energy savings periormance contract.

The Capital Inprovement Facilities Pian to build a new Advanced Technology Laboratory and rellovate several existing laboratories is currently in the design stage. Consideration of the many design options, including natural daylifghilng, building envelope, building maierals, boilding ventilation, and lighting controls, concerning energy conservation is being addressed and implemenlest as practical.

The Pacent and Trademark Office (PTO) is cumently reporting energy consumplion for GSA-delegated buildings with leases that expire in 1996 and 1997. Consequently, DOC cannot justify spending for improvements becanse the payback periods excead the terms of the tease. PTO's long-range bousing plans include a combination of long-term leased and owned 
buildings. Energy conservation will be a major consideration in the solicitation to acpuine these facilfifes.

The National Technical Infomation Service (NTIS) reports energy consumplion for one GSA-delegated leased facility. The current GSA schedple calls for NIIS relocation to a single site within 2 years, which makes it impractical for NIIS or its lessors to make major retrofitinvestments to reduce energy consumption. The draft solicitation easures the new NTIS facility will comply witb Federal energy performance standards.

At the Census Burean, an energy andit was conducted by Netional Energy Management Instiftute of Indiana, and an ESPC survey was conducted by Rayback, fac. The availability of finds and the cost-effectiveness will be factored in the decision-making process.

The Census Bureau completed more than 20 energy conservalicon projects, including lighting, air conditioning, controls, stem systems, tnsulation, windows, and others. Proposed projects includet electric motors, roof instlation, vestibules, expanding the energy management system, and others.

\section{Funding}

DOC obrains funding for projects from numerous sounces. In some facilities where DOC is in GSAdelegated buldings, GSA provtdes funding and contract oversightit. For example, $\$ 5.8$ million is approved in FY 1995 to reptace ligbing systems at the Herbent C. Hoover Building with new energy efficiency fixures, electronic ballasts, and T-8 tamps. The project includes dayllghting controls in offrces with windows and motion/occupancy sensors in less frequently used areas. In addition, $\$ 10$ milition is approwed for FX 1995 to replace existing chillers with three energy efficient CFCfree chitters. The local utility company, Potomac Electric Power Company, is reviewing the applicalion for rebates as part of their demand side management program.

\section{Energy Savings Purotmance Contracts}

Large projects identified as part of the NIST Site Utilities Master Plan will be used to develop the basis for an energy savings petformance contract. At the Census Bureaut, an energy audit and an ESP contract survey was conducted.

\section{Demand Side Management}

The Natiotal Ocentic and Atmospheric Administratton (NOAA) is participating with the local ntility company to obtain rebates for energy conservation projects at two sites where DSM progranis are offered. Recently the utility company has reduced or eliminated rebates offered.
PTO has initiated discussions with Virginin Power regarding the utiltity company's three-stage audit program. Under this program, Virginia Power first does an andit of electric binings, and an analysis of customer's usage compared to the normal range. Nent, Virginta Power performs on-sibe surveys and finally (if indicated) Virginia Power povides a recommendiation based on tife-cycle cost analysis.

The Census Bureav plans to achieve the energy efficiency goals by working with Public Service Indiann (PSI), the local utility company, to develop a program for DSM. The PSI has conducted an energy arktit and provided recommendations to the Bureau.

\section{Vehitcles}

Emphasis hes been placed on the procurement of the most energy-efficient vehicles. Budget restrlations and program reductions have decreased the number of rriles driven in agency-owned, commercinly-leased, privarely. owned, and GSA Motor Pool vehicles.

NOAA and NIST conlinte to procurs alfernative fixeled vehlcles through GSA. An attempt to procure natural gas-fueled veblcles failed, but GSA is currently attempting to find an alternate source.

\author{
Knergy Management Contact \\ Mr. Janes Woods \\ Energy Manager \\ Office of Federal Property Programs \\ U.S. Department of Commerce \\ Herbert C. Hoover Building, Room 1329 \\ 14th and Constitution Avenue, NW \\ Washington, DC 20230 \\ Phope: 202.482.0885 \\ Fax: 202-482-1969
}




\section{DEPARTMENT OF DEFENSE}

Energy Enclency Per[akmance and Impieraentation Strategtes In FY 1994, the Departinent of Defence reported a decrease in its buildings and facilities energy of 11.7 percent in Btm per gross square foot compared to FY 1985.

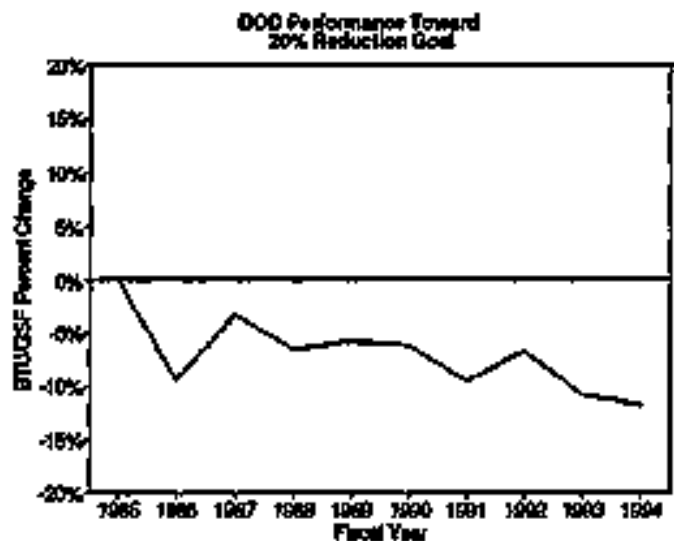

Each component of the Detense Department bas the responsibility for developing and implementing its own plan for meeting the mandated energy maragement requirements.

The inoflemertation strategy of the U.S. Army is to give the arajor Army Commands and installations the flexthility to nun thetr own individual entergy programs. The general objectives of the Army is to improwe energy efficiency and eliminate entergy waste by investing in etorgy efficient technologies, installing energy mouitoring and control systems, updating Architectural and Enginering Instructions design specifications, and using energy savings performance coniracts and utilitysponsared demand side maragement incentives to leverage energy efficieacy investment.

In April 1994, the Cbief of Naval Operations (CNO) issued OPNAVINST $4100.5 \mathrm{D}$ in response to guidance and requinements contained in EPACT and Execotive Order 12902. In May I994, CNO issued its Navy Energy Plan, in August 1994, the Navy submitted its revised Shore Factilities Energy Implememiation Plan to meet the requirements of Execulive Order $\mathbf{3 2 9 0 2}$ as well as outline a strategy to identify aud implement a method and fundting requirements to accomplish these requirements.

The Air Force uses a decentralized approach to implement energy conservation requirements. The Headquarters iscues general policy stalements to advise of requirements. Major Commsnds (MAJCOMs) are expected to implement necessary actions to achieve the goals within their comnands. MAJCOMs have inlitiated their own plans and wak through energy stering groups to pet more emphasis on energy prograrts. MAJCOMs encourage their bases to develop individual plans and work fhrough their bass level energy steering groups.

In February 1994, "Marise Corps Energy Conservation Campaign Plan" was putlished. This plan ovtlined the Marine Corps strategy for achieving the energy use reduction requirements. Hegdquarters Marine Corpshas increased emphtasis on energy awareness, improved corrmumication with field activities and provided greater focals on identification and development of energy conservation projects. Marine Comps installations are continuting to update and isswe orders tailored to their specific situations, update base Master Plans, estrblish Appraisal Boands to involve all activify personnel in the planning and oversight of energy management, and ensure destgn and consintretion criteria with life cycle cost analysis are integrated into the facilities acquisition process.

Imperved operations and maintenance (O\&M) activities are a critical element in the $\mathrm{D} 0 \mathrm{D}$ energy management program.

O\&M procedures are continually being reviewed and updated by the Navy to ensure efficiency and cost effectiveness. The Navy is passuing an aggressive campeign to heighter the energy awareness and increase the training of all design, installation, operation, supply, and maintenance personnel.

Major O\&M iritiatives are occurring throughout the Air Force to reduce energy uxage. Examples of operational changes include establishing a base-wide compressed work week schedule (Hill AFB), establishing no-beatingho-cooling seasous (Robins AFB), eliminating portable electric space beaters and stocting of energy efficientlamps (Wright-Patterson AFB), and removing small office refrigerabors (Kirllend AFB). The Air Force continues to emptasize the firect link between equipment maintenance and energy conservation. Adeguate training is empbasized to ensure personnel are trained in the contect maintenarice procedures for their equipstent. Emphasis has been placed on moritoring and maintaing major energy consurters such as central bealing systems, lighting systerns, and HVAC systems. Finally, Air Force bases are etcouraged to actively pursus metering of all major energy consumers. 
Throughont the Marine Cops, there is a continued emphasis on operarion and maintentince of enerby systems with the uझe of computerized programs and remotely locased, antomatic controls. Headquarters Marine Corps completed development of an arificial intelligence dembonstration program at the Marine Corps Air Groumd Combar Center in Twenty-nine Palmas, Califoraia This project provides central heating plant operators real-time monitoring of the central plant and diagnostics of efficlency degradation. The project has resulted In sustained operation at greater efficiency and provldes conthual training of the ptant operators. The system will begin to be exported wother Marine Corps beatigg ptants and utility systems in FY 1995. Development work in FY 1994 cost \$486,000.

\section{Sorveys}

In FY 1994, the Navy spent nearly 53.0 mitliom for energy surveys and enesgy project development. The surveys concentrated principally on identifying lighting retrofits. Over $\$ 186$ million of potential projects (of all types) were identifted, and the Navy is currently deweloping an execution plan for these projects.

In FY 1994, the Marine Cops spent nearly \$1.4 million for energy surveys. The 1994 surveys and studies addressed: ligbting retrofits, stem system and condensete live replacement and insulation, gas line leaks, EMCS and diret digital Corterol (DDC) feasibility applications, facility envelope insulation, window replacement, iefraret malysis, high efficiency motors applications, and electrical fisuribution system upgrades.

Several Air Force MAJCOMs and bases have used anditing prograns aveilable from their local usility company where applicable. Some MAJCOMs use inbouse persomel to coaduct andits. Air Combat Comenind headquarters personnel use a four member Facility Energy Assistance Team to perform energy audits at their bases in conjunction with base energy managers. The Air Nationat Guard completed full base couprebersive energy surveys at 22 bases and have 30 more planned for FY 1995.

\section{Training}

The Huntsville Division of the U.S. Army Corps of Engineers (COE) spousored by the Center for Public Works conducted to one-week courses to train entrgy managers in FY 1994. The course meets to reguinements of EPACT for trained energy managess. The COE Cenker for Public Works also condizcted a workshop for energy mangers and energy coondinators to provicte information on funding for DoD Energy Conservation Investment Program (ECIF) and DSM programs in Jnee 1994. The U.S. Amy Logistics Evaluation Agency presented the 34-hour trainung course for Amy Energy Coordinators at the Aray Logistics Mangigement College, Fort Lee, Virginia twice during FY 1994. Army persontel also particjpated in several professional development opportunities inclading the World Energy Engineering Congress.

The Navy conducted for sessions of an in-house energy management sourse. The course covered funding avaikable for projects, a wide variety of tecbpologies, energy data reparing and measurement, and presentations by Defense Logistics Agency, Pacific Northwest Laboratory, and activlty energy managers. Input was solicited from successful Navy energy managers on redesigning the in-honse course to comply with EPACT. In FY 1994, the Navy spent \$856,100 to train 382 energy mantagers in areas required by EPACT.

The Air Forec conducted two training seminars in conjunction with base energy managers meetings. In tour eaergy manager training classes, 150 energy managers were trajned. Additional energy manager training classes are schoduled in FY 1995 and will be conducted as part of the Air Force Civil Engineer School's regular schedole. A new conrse was developed at Wright Patterson AFB to address energy effictency.

As of the end of FY 1994 Headquarters Matins Corps has scheduled its second ose-week seminar for installation energy managers for February 1995. Headquarters Martue Corps is continuing to fund energy training though the use of $O \& M$ funds by programming $\$ 200,000$ for exergy training during FY 1995.

\section{Funding}

In FY 1994, $\$ 50$ million was available DoD-wide to be expended on projects programmed in the military construction-fuoded ECIP program. The criteria for prioritization for projects fimited through $\mathrm{ECIP}$ is based on shortest discounted payback using the Federal lifecycle costing wethodology. Projects are also evaluated for additional factors such as probability of savings longevity, technical mahurity, use of rewewable energy resoures, and related environmental and mission stppport benefius. An additional $\$ 59$ millikn in O\&M funds were dedicated DoD-wide to energy effjciency projects.

Energy Savings PerEarmance Contracts DoD has 11 energy savings perfomance contracts in place, three of which were awarded during FY 1994.

The Army has awanded five ESPC contracts to date. On January 31, 1994 a contract was awarded at Fort Polk, Loujisima to install closed loop ground sovece heat pumps at 4,003 family bousing units. The contractor 
will also concurrenily insulate attics, add weather stripping and eaulking, install low-flow shower heads and residential hot water desuperbesters, insulate water heaters, and retrofit interixor and exterior lighting. The contract tarn is for 20 years with a contractor capital investment of $\$ 18$ million. The Amy's projected share of savings is almost $\$ 10$ million (22 percent) with the coniractor's share of savings projected at \$34 million (78 percent).

The other Army ESPC projects ipclude:

- Replacement of a steam fueled absorption chiller with an electrical chiller at the Corpus Cristi Anny Depot, Texas. This contract was awanded in September 1988 and has a term of 25 years.

- Reptacement of AC units, EMCS controls, lighting retrofit, shower bead replacement, water heater insulation, and other energy conservation actions at Aliamann Housing Reservation, Fort Shafter, Hawail. This contract was awarded in February 1991 and bas a contract term of 15 years.

- Upgrade and expension of a propane-air mixing plant to provide backup capability for nabral gas system at Fort Stewart, Georgia. This contract was awarded in March 1992 and has a term of 15 years with a 5 year option.

- Installation of a propane-air mixing plant to supplement the natural ges system at Fort McFherson/Gillem, Georgia. The propant-air mixing piant permits Fort McPtherson to buy interruptible rale natural gas during peak denand periods. The contract was awarded in July 1992 and has a term of 15 years with a 5 year option.

The Atr Force has two ESPC projects in place both of which were awarted in FY 1994. The first phase of an ESFC project at Randolph Air Fonce Base, Texas has been completed. Awarded in Februiry 1994, it involves relamping several large facilities with options to add other facilities. The first phase included changing out over 15,000 old, inefficient, furorescent and incandescent light fixtures for a savings of 4.5 million kWh, netíng over $\$ 239,000$ in energy savings. Phase II provides for follow-en negotiations of other electrieal savings iniliatiwes. Randolph's energy manager has aiready ittentified over 11,000 fixlures to replace in phase two. Initial csitimates indicate saving of 3,4 million $\mathrm{kWh}$ and $\$ 170,000$.

An ESPC was awirded at Hill Air Force Base, Utah in early July 1994. This is a base-wide ESPC with supplemental funding from the local utility company. Estimated savings are 44.2 million $\mathrm{kWh}$ (\$1.5 million) over a 5 year period and shonld reduce the base's peak load by 18 percent.

The Navy has two active ESPCs, one atNaval Training Center, Great Lakes, installed in November 1990, the other at Naval Alr Warfare Center, Patoxent River, installed in February 1992. The Great Lakes project inclodes one building lighting retrofte and an EMCS for building air handlers, boilers and chillers. The Patuxent River project retrofits lighting in 52 adtrinistrative and comenumity buildings.

The Defense Counmissary Agency (DeCA) currently has two energy savings performance contracts in placer othe for Muramar Naval Station Commissary and one for eight other locations in the San Diego area Both comtracts were transferred to DeCA for administration in March 1992. The contractor installed Edison 21 energy governors, reduced the number of light fixtures and reduced the watts of the remaining fixtures from 100 watts to 60 watts. The Goverument should achiove a gross annual savings of $\$ 153,532$. The Navy origimally projecked an entergy cost sovings of neary \$1.7 million over the life of the contract.

\section{Demand Side Management}

Numerous actions wero initialed witbin the Army to take advantage of utitity DSM programs. Guidance was provided to major commands and installalions for taking advantage of DSM opportunities. Meetings have been held with Commands and installations to expedito program inmlementation. A session covering DSM was added to be Energy Coorfinalor Course and the Energy Awareness Seminar program.

The Navy has negotiated a Basic Ordering Agrecment (BOA) with Sar Diego Gas and Electric (SDG\&E) Company for a DSM program at Marine Corps Base (MCB) Camp Pendleton. The BOA was selected for recognition in the National Ferformance Review. A San Diego areg-wide lighting retrofit program is also moderway with SDCG\&E. The Navy has particjpated with Southen California Edison, Pacific Gas \& Electric Co. GSA, and otber govemment agencies to take advantige of DSM programs with these utility companies. Agreements are in process with the Bonnevilte Power Authority (BPA) to pemit naval activities to accept incentives from BPA. The Navy has held exploratory discussions with several utility companies to determine possible beneficial relationships. A pilot project with the new Southern California Edison ENVEST program is under consideration. 
During FY 1994, the Afr Force conducted ongoing activities with several electric and gas vility companies to develop mitually agreeable generic and project specific DSM contracts. A generic agreement between Sacramento Muticipal Utility District (SMUD) and MoClellem AFB, Califormin was signed in which SMITD will provide partial famding, up-front financing and turnkey project work. Contract negotiations are in also adpanced stages with Niagara Mothawk Power Corpora. tion, Nevada Power Company, Pacific Gas and Electric Company and Sontheru Califonia Edison for generic agreements.

The Air Force Acatenny has volunteered to be part of a Colorado Springs public utilicy company DSM pilot program for energy audits. Hanscoon AFB is currently inwolved in a DSM program with Boston Edison to retroff motors, lighting, and heating systems. The base is a member of the Boston Exilson Energy Cooperative (kocal industries whop agree to ctrtail electrical use during peak loads) and have received $\$ 200,000$ in rebates ower the last 4 years. Eglin AFB is also pursuing a gas fired chiller DSM project with Oskaloosa Gas. A DSM project was imitiated between MCClellan AFB and its utility compary to do lighting relrofts. The initial costs will be furded by the utility company which will recover costs by actual entergy savings and monthly prorated thilling based on the intitial construction cost mimus actual energy savings. Other beses inchuding Edwards, Las Angeles, and Rotins are working with their local utilities to develop similar saving opportunities. Patrick AFB and Cape Canaveral AFS have entened intu a DSM effot with Florida Power and Light. The initial phase of the effort will retrofit lighting in the vertical integration building at $\mathrm{C}$ ape Carnateral. This retrofit when completed will save 2.8 billion Btu and \$42,500 dolkars antually.

In September 1994, Dover AFB and Ohesnpeake Utilites signed an agreement whereby the utility will extend a cutaral gas main over 3 miles to a meterimg point adjacent to Dover's central best plant. In retum, Dover AFB will pay the utility $\$ 420,000$ to extend natural gas from the metering starion to the central heat plant and convert two of the boilers there to primary nalural gas firing, with \#t fuel oil firing as backup. Energy cost savings are estimated at $\$ 500,000$ annually over the first 5 years.

The Marize Cors Installarions and Logistics Depantment assisted in the development of a pilot project developing a base-wide opea scope ESPDSSM contract at MCB Camp Pendleton, CA. Marine Corps installations are receiving rebates and servites from local utilities.

\section{Vebicles}

The Air Force greatily expanded its Altenlative Fueled Vebicle (AFV) program in FY 1994. With over 675 Alr Force-optued AFVs located at 14 installations, the Air Force has been steadily increasing its inventory of Compressed Natural Gas (CNG) vehicles along witb infrastructure needed to support them. In addilion to the $\$ 4$ AFVs already bonght with Air Foree vehicle procurement funds, the Air Force anticipates being atile to acquire approximately 700 additional CNO vehicles and 15 adkitional CNG stztions utilizing FY 1994 funds avaitable to the Air Foree from the DoD Advanced Research Projects Agency (ARPA) and DOE.

On the infrastnxchure front, the Air Force has been successful in having the natural gas industry build CNG stations in Forida cond Colorgdo by guaranteeing the fuel pnovider a given number of CNO vehicles will refivel at these facilities. Increased CNG infrasinucture will permit addifional vebicle requirements to be converted from gasoline and tiesel to CNG in the future.

The Air Force has seven bases actively participating in ARPA's electric vehicle demonstration program by tield testing a variety of vehicle types from sedans and pickup trucks to vans and shuitte buses. The basas are Edwards AFE, McClellan AFB, and Vandenberg AFB is Califortia; Harscom AEB, Massachusetts; Patrick AFB, Fiorida; Robins AFB, Georgia; and Hickam AFB, Hawait. In addition, three electric pickup trucks were ordered throush DOE and will be field tested at WrightPatterson AFB, Obio; Tinker AFB, Oklahoma; and Langley AFB, Virginja.

The Marine Cops continues to buy fuel efficient wehicles and substitute portions of its atendard fuel Gerison Mobile Eqpipmient fleet with alternative tuel and electric vehicles. The Navy is procuring state-of-art fuel efficient vehictes dhrough GSA for replacement of an agiag flest The Navy acquired, purchased, converted, and leased 1,010 altentative futel vebicles during FY 1994. The Amy leases all of its adminismative vehicles through GSA, including altertative fud velhicles.

\author{
Energy Management Contact \\ Mr. Milard Carr \\ Director, Energy and Engimeering \\ Office of the Assistant Sectetary of Defense \\ (Economic Security) \\ U.S. Department of Defense, Room 206 \\ 400 Army Navy Drive \\ Arlington, VA 22204.2884 \\ Phone: 703-604-6022 \\ Fax: 703-604-6024
}




\section{DEPARTMENT OF ENERGY}

Energy Efliciency Performance and

Implementation Strategles

Duting FY 1994, the Department of Energy reported a 23.2 percent reduction in buildings consumption in Btis per gnoss square foot compared to FY 1985.

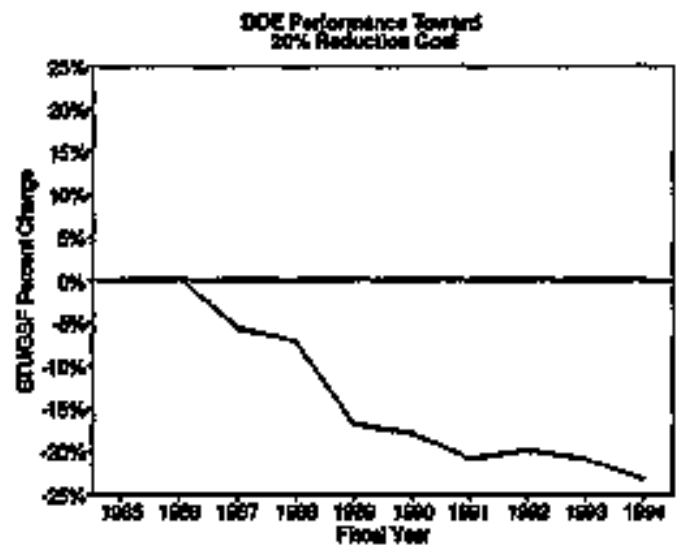

The DOE Energy Management Plan was revised to incorporate we requitements of Execotive Order 12759 and be Energy Policy Act. The new Energy Management Plan describes a comprehensive program to accomplish the gosis and requilements of the Execullue Order. Further revision is underway as a resulf of Executive Order 12902.

Operation and mainfenance procedures are used to increase energy efficiency at DOE through efficient operation of brildings, inproved preventive mairtenlance, and improved energy trainiug for personmel. Exampless include:

- Thermograph techopiques to locate "hot spots" in energy systems;

- HVAC Maintenarce Program

- Set back and shutdown of laboratory fumebood exhaust systems;

- Use of pre-engineered operating schedules to optimize chilles plant operations;

- An apgressive steam-trap inspection and replacement program;

- Annual boiler tume-up procedures.

Many DOE sites have also implemented a number of ongoing energy-saving measures sucb as: instillation of $\mathrm{EMCS}$, replecement of roors, replacement of mercury vapor lamps with tighet efficiency metal halide tamps where feasibie, replacing oid fluorescent Jamps and ballasts with high efficiency lamps and electronic ballasts, itstallation of energy-efficient lighting with antomatic on-off control systems, replacements of butding satellite boilers, and maintentance and upgrade of HVAC equipment and systems to optimize performanice.

Examples of energy-efficiency projects finded and accomplished in FY 1994 include the following:

- The Fluorescent Liglating Replacement Project at the Headquarters Germantown Building, Germantown, Marylind was jointly fimded by HQ In-house Energy Managentert and the GSA for approximately $\$ 900,000$, this project will resuce lighting consumption by 60 percent. The estimated ann:1al savings are $2,454,503 \mathrm{Kwh}$ and $\$ 176,000$. The local utifity, Potomac Electric Power Company will provide a rekate of $\$ 115,594$.

- Rehear Control Design for the Headquartess Forrestal Energy Mamagement and Control System (EMCS). Project cost is estimated ac $\$ 1.2$ mitlion and is projected to save 3.3 billion Btu per year.

- Replacement of electromagnetic ballasts with electronic ballasts, downlamping fixtures, and installacion of motion sensors at Argonte National Laboratory-Egst (ANL-E) in Argonme, mimois. This project's estimated cost is \$1.I million with an estimated annul savings of $\$ 228,900$ per year. ANL. E also replaced an inefficient 800-ton CFC citller with two 400-1n high effikiency clitlers in builking 200 at a cost of $\$ 650,000$ with estimated savings of \$85,600 per year. Also, a 1000-ton jnefficient steam absorption chiller was replaced at a cost of $\$ 710,000$ with estimated savings of $\$ 144,300$ annually.

- Naval Petroleum Reserves in California (NPR-1) completely retrofitted all remaining T-12 four-foot standard fluorescent lamps to extergy saving electrontic T.8 bellests and lamps. This project resulted in atmual savings of 1,145,475 $\mathrm{kWh}$ and received a rebate of $\$ 31,444$ from the locas utility company, Patific Gas \& Electric Company (PGRE).

- The Oak Ridge National Laboratory in Oak Ridge, Tennessee completed the direct digital controls project which will save $\$ 350,000$ asmially in energy cost and recoup all investment cost in 3.1 years.

Funding

At DOE, funding for energy surveys in boillding and processes amousted to $\$ 6.3$ million in FY 1994, with 
a total expenditure of $\$ 47$ million since FY 1978 . Also during FY 1994, DOE invested \$18.6 million im 82 retrofit profects in butiling and metered process facilities. The anticipated savings in boildings from DOE's FY 1994 retrofit program is 780 billion Btu. Since the beginning of the retrofit program in FY 1977, 1,100 projects costing $\$ 290$ milliot were funded to redoces ezergy consumption and costs in buildings and metered process. The fundied projects bave a projected anoual savings of 42.5 trillion Btu and $\$ 101.4$ million. These savings represent a 2- to 3-year payback

\section{Energy Savings Performance Contracts}

Curnently the Depeatment bas two energy saving performance contracts in place. Lawrence Berkeley Laboratory had one ESPC awarded in FY 1991. The scope of this project included a vatiahle frequency dive on the mais air handling system, antomatic controls of centril plant equipulent, motor neplacements, bot weter valve tephacements, lighting upgrades to T-8 lamps and electric ballasts, and LED exit siggis.

The HQ Forrestal Btyilding had an ESPC stigned in FY 1993. The annual savings at DOE's Fomestal beilding will amount to approximateIy $\$ 400,000$ and over 6 million $\mathrm{kWh}$. This ESPC is for 7 years. DOE's share of the savings will be $\$ 108,000$ in the first 3 years of the contract and increasing of $\$ 339,000$ in the remaining 4 years of the contract.

\section{Demand Stde Management}

DOE sites continue to particlpate in utillity company demind-side Ifanagement prograns. Examples of DOE sites penticipating in derand-side manggenent progrants include the following:

- NPR-1 received a rebate of $\$ 208,82$ from the local utility PG\&E resuiting from the Waterflood Flow Monitor project. This project results in epergy savings of 9.5 million kWh annually. NPR-1 also received a $\$ 184,000$ rebete from $P G \& E$ as a result of the Waterflood Replacemeat Punp project. Installation of these bigh efficiency pomps saved a total of 5.4 million $\mathrm{kWh}$ artioally.

- The Nevada Test Site (NIS) bas implemented a Inad management scheme on selected bailinings with plans for update/expansion of the existing system. NTS also participates in a rate manegement popram with tis local utility. The Nevada Power Company.

- During FY 1994 the Western Area Power Administration (WAPA) sponsored or co-sponsored workshops on demand-side planning, new load management tectmologies, load management for smakler utilities, power quality, markeling, Intrared cameras, electric heating, irrigation pump testing, power factor improvement, load analysis and monicoring, and lighting technology. These workshops are aimed at customers boweter, WAPA employee are encouraged to altend as participants or abservers.

- The Hanford Sita in Richland, Wasbington received six rebate checks lotaling \$46,546 from their local utility. Also, the city of Richland provided \$163,000 to Pacific Northwest Lakoratory at Hanford for it's newest brilating, the Environmertal Tephnology Building with energy features that reduce electrical consuruption by 30 percent.

Vehicles

To meet the energy conservation goals of minimizing the use of petroleum products and decreasing gasoline and diesel fuel consumpeion by 10 percent by FY 1995 , DOE has acquired more entergy efficient vebicles and alterbative fueled vebicles, downsized vehicles when apjoogriate, Uygraded preventive meinterance prograns, and implemented driver awareness training, and employee outreach.

Fleet vebicles in a number of locations were, or will soon be converted from gasoline to methanol or duel fuel. Liquified getroleum ges, Jiquified satural gas, compressed natural gas, and electric vehicles are some of the otber alternative foels currently in use.

\section{Envirobituental Benefts}

Examples of environimental benefits at DOE during FY 1994 were, reduction of chlorofluorocarbons (CFCs) through projects to replace CFC chillers with new higher efficiency, non-CFC chillers, reftigerant recovery programs, safely disposing of obsolete fluorescent ballests, and reduction of tailpipe emissions from the use of compressed natural gas vehicles at mianty of the DOE sites. The use of soy-besed intss which are envirommentally friendly ane used in some DOE print plants. Site-wide recycling of alminum beverage cans, batteries, paper products, and fluorescent lamps, are in existence at many of the DOE sites.

Energy Management Contact

Mr. Victor P. Petrolati, EE-91

Federal Energy Management Program

In-bouse Evergy Management Division

U.S. Department of Energy

1000 Independence Avenue S.W.

Washington, DC 20585

Phone: 202-586-4549

Fax: 202-586-2007 


\section{DEPARTMENT OF HEALTH AND HUMAN SERVICES}

Finergy Efficiency Pertormance and

Implementation Sirategies

The Department of Health and Human Services reported an 8.7 percent reduction in buildings consumption in Btu per gross square foot in FY 1994 when compared to $F Y 1985$.

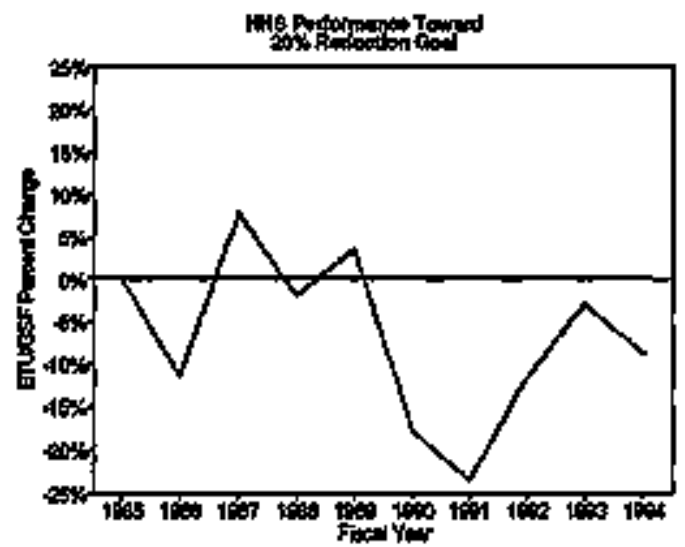

In 1985, HHS developed and implemented a Departmentwide encrgy reduction plan. The operating divistons of HHLS Soclal Security Administration (SSA), Public Heallh Service (PHS), Hiealib Care Financing Adringtstration, and Office of the Secretary - have estatlished implenentation plans consistent with the provisions of legtslative and Executive Order authorities.

Durjng FY 1994, HHS accomplished energy savings despite the fact that new, energy intenslye medical treatment equipmeat and laboratory operations continue to increase ejectrical usage throughoux many HES Gospitak, outpatient clinics, laboratories, and tesearch facilities. During FY 1994, HHS continmed the succossfril implementalion of many no-cost and low-cost energy conservation measures.

In FY 1994, the SSA undertook a number of energy efficiency activities which are described below.

- Repiaced existing lighting in the Metro West Complex with energy-effictent T-8 lamps and high pressure sodinm lighting. The project will save apporoximately $\$ 280,000$ annually in electrical and maintenance costs and 2 million $\mathrm{xWh}$ of electricity per year. The project was funded by CSSA at a cost of over $\$ 1.1$ million and should provide a $\$ 400,000$ rebate from the utility.

- Replaced existing lighting in the Supply Building to energy-eficicient T-8 tamps and high pressure sodium lighting. The project should save $\$ 27,050$ annually in electrical and maintenance costs and $275,000 \mathrm{kWh}$ of electrictity per year. The project was funded by GSA at a cost of $\$ 57,000$ and should provide a $\$ 17,000$ rebate from the utility.

- Replaced existing motors in the Operations Butlding with energy-efhiciept molors. The project should

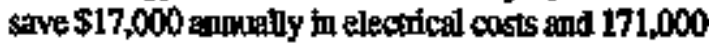
kilowatt bours of electriclty per yeer. The project was funded by GSA at a cost of $\$ S 5,000$ and shogtd provlds a $\$ 3,000$ rebate from the utility.

- Installed new steam traps in many of its mechanical spaces at the Heacquarters complex. SSA funded this project at a cost of 523,000 .

Ar employee energy efficlency campaign at SSA continues that includes anticles in a monthly belletin to explain SSA's energy conservation strategies and provides examples of $\mathrm{h}$ (hw the employses cm participale.

In FY 1994, the Public Health Service condacted the bollowing activities:

- Upgraded ligbting, replaced existing boilers and chillers, and other building service equipment with more energy efficient models as part of regalar building upgrading.

- Some ołder, energy inefficient buildings were replaced wilb new buildings that have a strong design emphasts on energy efficiency.

- Installed thermal energy storage facilities and cogeneration equipment as part of major infrastrocture renovations.

- Added insutation, installed thermally-effictent windows, npgraded lighting flxures and other equipment in existling bullings.

- Converted the Parklawn Butlding in Rockville, Maryland, from a strictly oil based facility to a dual cil/anhiral gas operation.

At the Office of the Secretary of Health and Human Services, the following energy conservation activities have taken place in FY 1994:

- Expanted the use of motton sensor tighting controls throughout the Headquarters building. 
- Updated the recently installed HVAC control and monitoring system.

- Used "free-cooling" whenever ovtside air tenperaarres permit to avoid the need for chiller operations when indoor temperautre is too high.

- All public restrooms, conference nooms, and conridors ubilize T-8 fluorescent abes, electronic ballasks and motion sensors.

In an effoxt to meet exergy mantagemeat goals, the Health Care Fingacing Adintinistretion (HCFA) minitors the delegated HCFA.leased brildings daily to ensure lessor complinge with lease requitrements, energy manggement requiriements, and Federal Property Management Regulations for hering, cooling, and Hghting.

\section{Training}

Operating divisloas throughout HHS have sent policy mimagers, building managers and staff to a variaty of training chasses ranging from al ternative fuxels, lighting, controls, and demand-side management practices.

\section{Funding}

Components throughout $H H S$ are developing plans for funding energy conservation pojects. For example, SSA has received several million dollars from the GSA fund (S1.4 arillion in FY 1994) for financing energy neduction projects. SSA also spent $\$ 600,000$ of its own funds on etrergy efficiency profects.

All HHS components have been instructed to develop entergy conservation projects that will qualify for the DOE Federal Energy Eficiency Fund (two have been accepted for FY 1995). Components have also been instructed to prioritize enersy efficient invesiments according to their savings-to-investment ratios.

\section{Energy Savings Petformance Contracls}

SSA has techatcal and contracting enployees fully trained tn ESP contracting. Eaergy audits are cumtently being condocted to develop ESP contracts. In the next 6 years, many of SSA's delegated facilities will see extensive renovations as part of the SSAGSA proppectus program. Many of the projects noted in the ponspectus make ideal candidates for ESP contracts and are tincluded in the overall ptan.

PHS reports that a significant percertige of PHS facilities are facing the possibility of a major change in function (e.g., from office to laborateries) due to evolving agency missions. Many of the remaining buildings are scheduled or proposed for renovation or replacement, due to age or increasing demand on the facilities. As a result, energy conservation planuing is included with retrofit or renovation projects and not considered as Iong-term shared entergy activities.

The Indinn Healch Service (IHS) has entered into discussions with the Navajo Tribe concerning the possibility of implementing an energy savings performance contract for lits facilitles on the reservation.

\section{Demand Stde Management}

The Office of the Secretary of Healdh and Human Services received $\$ 21,700$ in rebates from Potomac Electric Power Company during 1994 tor Hebing conservation measures.

PHS's herger installations such as the National Institotes of Health and the Centers for Disease Control have fard agrements with locil utility componies for load shedding during peak demeand. As standard operating puocedurt, plant operators monitor demand loads and mipimize then whenever possibte to achieve the lowest rate.

SSA Headquarters is actively participating in DSM rebalo progeams. SSA expects approximately $\$ 400,000$ in rebates in FY 1995 for projects awarded late in FY 1994 and FY 1995.

\section{Water Conservation}

SSA acconplished two projects in FY 1994 in the area of water conservation. The first was the installation of low flow aerains for faucets $(523,000)$ and the second was the purchase of automatic flush valpes for water closets and urinals $(\$ 23,500)$. The geratons were installed late in the fiscal year and ro data is available regarding the amount of water saved. Additionas materials must be ordered to install the new flush valves. This project will be completed in FY 1995.

SSA bas installed walet meters on all cooling towers make-up lines at its Headqutarters boildings. SSA receives a credit at the end of the year for water used in the cooling towtrs. In FY 1994, SSA earned a $\$ 80,000$ savings credst on its waste water bill.

Energy Management Contact

Mr. Scoul Waldman

Department-Wide Energy Manager

U.S. Department of Health and Human Services

HHS Cohen Building, Room 4700

330 Independence Avenue, $\$$

Waskington, DC 20201

Phout: 202-619-0426

Fax: 202-619-1407 


\section{DEPARTMENT OF HOUSING AND UIRBAN DEVELOPMENT}

\section{Energy Efliclency Performance and}

Implementatton Strategies

During FY 1994, the Department of Housing and Urtan Development reported a 0.5 pement decreese in buildings consumption in Btu per gross square foot conpared to FY 1985.

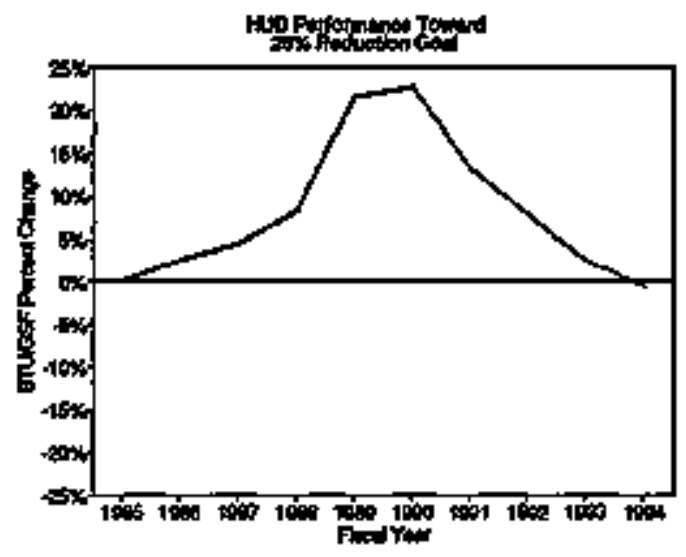

HUD aggressively pursues Energy Congervation Measures (ECMs), continicously reviewing operations to identify opportunities for energy savings. HUD submins energy ECMs to CSA for fimding through their specigl energy fund for buildings which have been delegated lo agency control. HUD's Oftice of Procurement and Contracts has accelerated the procimement process to award ECMs within the fiscal year they are proposed.

In FY 1994, HUD implemented the following energy conservation measures at its Headquarters Building:

- Replaced metcury vapor lights in the loeding dock with high pressure soditun lights (funded by GSA), and

- Continued participation in Potomec Elecric Power Company's (PEPCO) Electrical Laad Curtailment Program.

With the ienplementation of the following funne tnitiatives, tncluding an energy savings performances contract, HUD axpects to meet or exceed the mandated energy officiency goals:

- Upgrade toderiox and exterior lighting,

- Install economizer,

- Replace chillers and cooling tower,
- Install direct digial controls,

- Improve lighting controls,

- Replace packaged air conditioning units,

- Install occapancy sensors,

- Replate emergency exit signs wilh LED,

- Install photovoltaic sysiem.

- Install water conservation devices, and

- Install perimeter office lighting dayilight controls.

HUD's Rideshere Assistance Program enebles employses to be matched with compatible counmuters to and from work_Program effectiveness is doe to the Department's access to the Metropolitan Washington Council of Governtnents databank of over 10,000 registered comanuters. Additionally, rideshare promotional fliers are prominimently displayed in highly visible Iocations within the Department. During HUD's annual parking recertification period, carpool applicants are advised to complete a rideshare application to ensure baving a needed replacement to meet membership nequivements. There is a display of rideshare information available in the main lobby for employees and vistiors. In Jons 1994, the Department implemented a nationwide transit subsidy program to encoarage the use of mass transporta tion. Currently. Headquarters and 26 field offices are providing transit subsidies to 3,638 employees. Also, the Department's Oftice of Humlan Resources informs all new employees of the Department's rideshare and transit substdy programs.

Training

Several koy fIUD personoal involved in energy conservation received Energy Savings Performance Coatracting training through the Department of Energy.

HUD's energy coordinators during FY 1994 attended DOE's FEMP University which inctuded classes on Life Cyclo Cost Analysis, Federal Relighting Inttiatives, Federat Energy Decistion Screening, A Simpififed Energy Analysis Method, and Energy Rate Analysis. Personne] also atiended the 1994 Enwirowmental Management Team '94 Conference and the follow-tp wodkstrop for energy savings performance contracting. 
Funding

All energy conservation measures completed during FY 1994 were either fonded through the GSA special energy funt for delegated agencies or HUD's Builfiling Operations Repair and Alterations Funding. These projects were priocitized according to savings to investment ratio and payback period.

\section{Energy Savings Performance Cortuacting} HUD is currenty developing an ESPC solcitalion which it plans to bive out for competitive bid in FY 1995.

\section{Demand Side Mamegerpent}

Each year since 1985, fHJ has partictpated in PEPCO's curtailment lond program (CLP). In addllion, HUD operales its own CLP to noc exceed a specified demmod level. HUD also particjpates in PEPCO's rebate program and will receive rebates for the bigh pressure sodium lights installed at the Headquarters Bullding.

\section{Vehicles}

During FY 1994, HUD's overall vehicle inventory was reduced from 404 to 372 . Gasoline consumption was also reduced by 10,593 gallons from the previous year. GSA's 12-point fivel reduction tips were issued to all fiedd offers, along with instructions to follow the neanufachurer's recommendied schedule for torteups and to use a multi-grade energy conserving motor oil. Additionally, the following steps are planned to meet HUD's I995 fuxel usage goal:

- Headquarters will imptement a system to monitor the monthly status of vehicles to ersutre energy conservalion methods are being used.

- Stwitch to 21 melkanol fueled vebicks for FY 1995.

- Streamline the Department's nationwide fleet of velticles to reduce quantity and possibly engine size.

- Coordinate fiedd activities so that directional tips andfor travelers go at the same time.

Nationwide, gasoline type vehicles were replaced with 93 metbanol fueled vehicles. During FY 1993, HUD was successful in acquiring 84 methanol-ivel type vekicles through the GSA. During FY 1994, the Department was successful in acquiring an additional 9 methanol-fuel type vehicles. As the remaining 279 standard fuel vehicles reach thetr disposal timeframe, GSA is committed to replacing them with atlemative tuel vehicles.
Knergy Management Contact

Ms. Elaine Robinsom

Director

Building Operations Division

Department of Housing and Unam Development

Room 5180

451 7th Street, SW

Washington, DC 20410-3000

Phoule: 202-708-2711

Fax: 202-708-0299 


\section{DEPARTMENT OF THE INTERIOR}

Fnergy Eniciency Performance and

Inoplementation Strategies

In FY 1994, the Interior Deparment reported a decrease in energy consumption at buildiags of 13.2 percent in Bit per gross square foot compared to FY 1985.

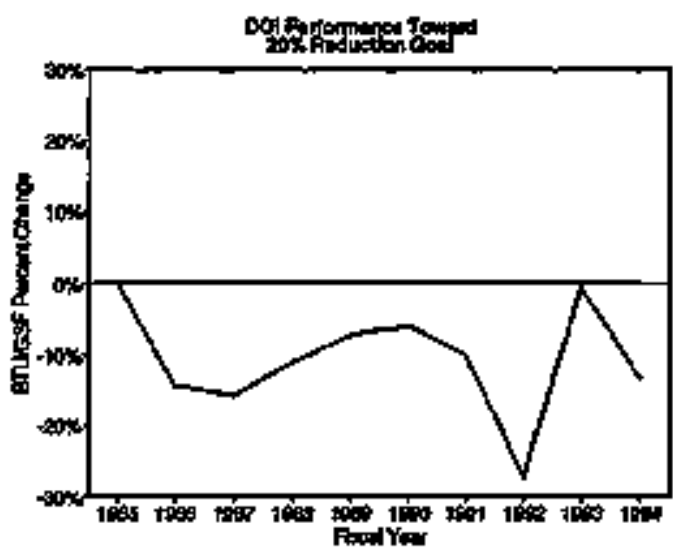

In July 1992, DOI instituted an Energy Menagentent Plan for Buildings and Facilities which updated the TenYear Opezations Phas developed under NECPA. The July 1992 Plan was updated further in December 1993. In FY 1994, in draft plan initintiog the implententation of Executive Order 12902 was developed.

Burebus continned to pefiorm ettergy studies on majox facilites. The stadies have led to removal of electric space heaters and reinforcetnent of basic naimtenance procedures to ensure that space heaters that are needed are in top operating condition, locking thermoxtats where cost effective, and tuming of furnace pilots during the cooling season. Heigbtened awareness of epergy maragement has led to expployec suggestions thciuding instalation of greenplugs on equipment with 110 volt motors.

The Fish and Wildife Service (FWS) completed pilot energy stuxies at firee energy-intensive research intstallations in FY 1993. These studies poirted out the need for a more accurate, unifom, and cost-effective methodology for detemining building and process energy consumption. It FY 1994, FWS developed a Process Energy Evaluation Model in a user-friendly format that was presented to the otier bureau energy coordinators.

Operations and maintenance efforts continued to be girned at identifying where high costs oocur, determining their cause, and pursuing corrective action. A reemphasis of basic maintenance on systems and nuachinery was part of the overall program to reduce energy cousuntption. Burean maintenance naanagement systems help identify energy conservalion opportumities and tratring programs will increase basic hands-on maintonance skills for facilities monagement stiffs.

Awareness programs instituted in prior years were

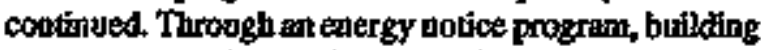
secupants receive written notification of energyconsuming equjpmeat such as lights, ntdios, and fans that bave not been tumed off through random surveys and scheduled inspections. DOI also has a computerized ridesharing program.

Tralning

The Bureatu of Lavd Management held its fust energy coxdintators meeting in Boise, Idaho, in May 1994. The Bureaw of Rectartition sent most of its energy menagess to the DOE-sponsoned Federal Energy Dectsion Screening training. The Burear's Provo Area Office developed a short video on value landscaping and water conservation.

Dol estirnated expendibues for training totaled $\$ 35,000$ and included courses from DOE's Federal Energy Markigement Program University and courses for those qualifying for trained energy manager status. \$cance rescources bas precluded additional training.

\section{Fonding}

DOI funded \$1.66 million in retrofit and capital equipunent for FY 1994 mod estimates firnding of $\$ 600,000$ for FY 1995. As in previous years, DOI funding for retrofit and capital improvemeats nesult for experditures from the bureaus' operations, maintenance, construction, and rebabilitation fonds. Entergy surveys have been conducted by contractors, utilities in conjunction with demand side management services, and ulilizing in-house expertise. Surveys bave identified additionel energy conservation opporthitites and retrofit projecls with implementation costs far exceeding the estimated finding for FY 1995. Maintenance projects are reviewed for their relation to energy conservalion measures and ahigh priorify is placed on those projects that would result in reducing energy consumption. Projects requiruig procarement actions are subject to value enginteering procedures.

Energy Savings Performance Contracts Dor's procurement offices, architect astd engineeriag divisions, and factlity managers are the management stuchure for implementing energy savings perfomolance condracis. They are expected to assist each other in specifying the requirements of the projects, qualifying 
contractors, and aparding contracts. Presently there are no ESPCs in place so procedures for use of the cost savings have not been developed.

Probletus identified by DOI in implementing ESPCs iaclude the lack of buildings wilh the econcanites of scale necessary to attract a contractor's tinterest. DOI owns many relatively small buildings, some of which are to poor condtition and have low energy consumplion. These buildings have low potential for an ESPC.

Demand Slde Management

Participation in utillty DSM programs continuad in FY 1994. In August 1993, the Fish and Wildlife Service (FWS) published "Demand Side Energy Management Guidelines." The guidelines, intended to assist regional FWS personnel to obtsin DSM services from utitities, were distributed througbout the Department. In addition, literature on rebate programs and other services offered by utility companies was distributed to the bureaus.

\section{Vehicles}

In FY 1994, DOI had a fleat of little over 33,000 vehicles, though the precise nimber of veticles at any one time fluctuates due to seasongl requirements, with continuons disposal and acquisition of vehictes lintroughout the year. DOI coordinated with other agencies, weilities, and automobile rimmetacturers to phan and facilitate the introduction of altentative fueled vehicles (AFVs) into its fleet ard to establisti infirstruo cure support, as well as pians to reduce DOI's depen. dence on petroleum. DoI designated the Presidio of San Francisco as its first Clean Transportation Zone, as defined through ant interagency agreement with DOE, the Departments of the Anmy and Transportation, and GSA. As a Clem Transportation Zone, the Presidio will be a proving groumd for testing entergy-efticient transportation systems and teclonologies for AFVs. In additica, DOL, through the assistmoe of DoD's Advanked Research Projects Agency and one of its regional consortium, accoured Interior's first electric transit vehick at the Paturent National Wildlife Research Center.

As of November 1994, DOI bureans operated a lotal of 345 AFVs. This represents an increase of 94 AFVs in DOr's fleet since April 1994. DOI's AFVs dedicated to operate on compressed natural gas (CNOG), and those that can use methanol (M-85) and ethanol (E-85) are leased through GSA. In addition, vehicles in the fleet that have been retrofitted to use CNG or liquified pecroleum gas (LPG) are DOI-owned vehicles. The use of bleaded and altentative fuels, and improved vebicle efficiency resulted in the average trile per gallon for the DOI fleet inFY 1994 increasing to about 16.5 miles per gallon, an improvement over the FY 1991 average of about 14.8 miles per gallon.

DOI will continue to emphasize fuel conservation by employing a diverse strategy based on the assumption thet to singlemethod or action will entable DOI to meet its goal. A combination of strategies is being inplementof at all organizational levels. The strategies include;

1) management support;

2) vehicle energy conservation planning and guidance;

3) introduction of AFVs, identification of convenient fueling infrastructure, and participalion in DOE's Clean Cities program;

4) employee awareness;

5) program incentives; and

6) program oversight and evaluation.

The extent and the timeliness in which these strategies are cactied out will depend on the avaitability of funding, Dew AFV's produced by the mto manufacturens, conventent AFV fueling and servicing infrastructure, and govemmemt and non-govemunent organizations to parimer with DOI on energy conserving and AFV initiatives.

\section{Environmenfal Activittes}

Recycling programs are in effect in manly bureats. Bureaus continued their implementation of affirmative procurement programs. FWS's program included procureantent of cement and concrete containing fly ash, recycled peper and paper prodncts, hubricating oils containing recycted oil, retread tires, and buildings insubation products containing recycled materials. The FWS "showeace" facility, the National Education and Training Center, West Virginia, will be built to specifications including requirements for the use of fy ash in the cement, reclaimed metals in the metal roof and siding, and recovered ingterials in the insulation.

Wherever possible, environmentally-compratible nonchlorofluorocirbon (CFC) thaterials or CFC substitutes are recommended for use in heating, ventilating, and air confitioning systems. Disposal of obsolite fhurescent ballasts is in compliance with local environmental regulations far solid waste disposal.

\author{
Bnergy Management Contact \\ Mr. Paul Denett \\ Director, Office of Acquisition and \\ Property Management \\ U.S. Department of the Interior \\ Main Interior Building, Room 5512 \\ 1849 C Street, NW \\ Wastington, DC 20240 \\ Phone: 202-208-3668 \\ Fax: 202-219-4244
}




\section{DEPARTMENT OF JUSTICE}

Baergy Emictency Perlormance and Implementation Strategies In FY 1994, the Deparment of Justice reported a decrease of energy consumption in baildings of 37.7 gercent in Btu per gross square foot coritgared to FY 1985.

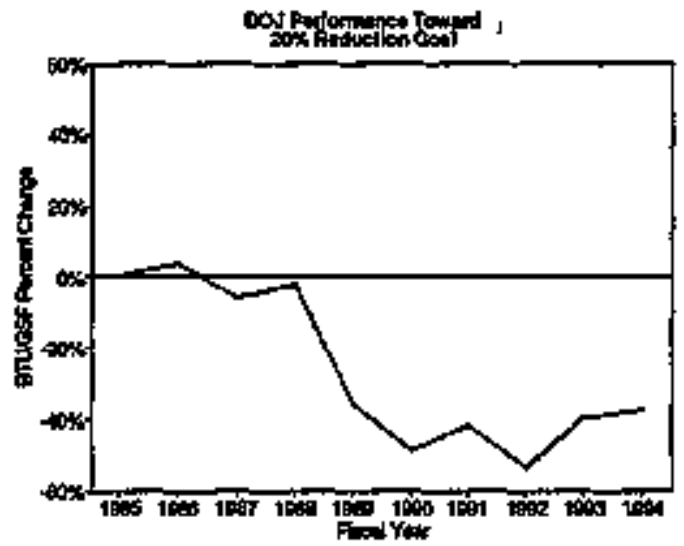

By April 1995, the Department of Justice intends to update the existing energy managernert and conservalion plan for dissemination to its bureaus. The revised ptan will inctude the requirements established by Executive Order 12902, Energy Efficiency and Water Conservation at Federal Buildings. The Deperiment also will develop the required plan to implement all energy and waker conservation measures with a 10-year or less payback. Requiremencs olt lined in Execplive Order 12902, such as developing a plar wo implement artilits of all required facilities within a 10-year period, also will be incorporated and developed tmder the Department's entergy conservalion strategy. The Bureatu of Prisons has updated portions of its facilities operations mantal to reflect cbanges necessitated by the passage of EPACT.

Energy surveys and comprebensive audits, as also required by Execulive Order 12902, began in FY 1994 and will continue util all required Departineat facilities bave been aucited. Additionally, a plan will be prepared to ensure ibat all required facilicies recejve a comprebensive audit/survey in a 10-year time frame.

In GSA-delegated buildings and Bureau of Prisons facilities, the Instice Department O\&M procedures are based on a computer software package detgiling preventive maintenance (PM) and O\&M on building systems and equipment. These HM packages are designed to ensure maximum efftciency of equjpmentbuilding system operation, thus conserving energy to the maximum extert practical In delegated buikgings, GSA approves the PM package utilized.
The Justice Department proctres goods and products in accordance with current Federal Acquisition Regulations and GSA supply/service regulations, polictes and guidelines. The Department regularly rectives GSA and contmercial vendor literature and product catalogs which contain energy-efficient goods and protucts. Energy-efficient products are ptirthased based on a lifecyale methodology.

The Justice Department hes undertisen numerous actions to ensure exergg efficiency in newlyconstucted brildings. The Foderal Burean of muestigation is working closely with the architect mold engineering fun designing the new Identification Division facility under construction in West Virginia Many enerpy-efficient coucepts have been included in the design of that facility. The destgn of the new Washington, DC facility wili be undertaken with a similar emphasis on energy efficiency, as well as including this project in the Potomac Electric Power Company's (PEPCO) efficient new building program. Also, the Main Justice Building in Washington, DC, is scheduled to receive a prospectus.] level modenization by GSA in FY 1997. Energy-efficient systems and equipment will be installed where practical.

DOJ has the capability to neawork with the Washington Merropolitan Council of Governtents computerized program to assist persontmel in obegining carpoo V/vanpool information. This year, the Department Employee Transportation Coordinator served as Government representative on a committee to select solitware to bring the existing system forward to the year 2000. A recent analysis of the Department's Rideshare program has show's a considerable increase in placement of applicants. Currently, the placement figure has increased from 33 percent to approximatefy 75 percent of all applicents. Quatterly checks with applicants have skowat the value of the program. Although the applicant numbers may vary, continued support of the Ridesharing Program inficales that Department entoloyees are being informed and are interested in this program.

\section{Training}

Due to budgetary constraints, the Department bas limited Funds to, expend on any training activities, including energy management. The Department does, however, attend low- or no-cost classes (DOE/FEMP-sponsored classes, GSA classes) whenever possible. Notification of such classes are iminediately passed on to the Department's bureans in order for their energy managers to attend. Also, energy conservation is a topic during 
the bíbantuual Burealu of Prisons facilties management training course.

\section{Fanding}

Fuading requests for energy conservation retroft ts and capital equifpentent requirenents are considered on a caseby-case besis. Projects are priotitized in onder of emergency, life and fire safety, mission operatlonal, or maintenance necessity. Corsideration is given to lifecycle cost effectiveness, equipnient condition, savings-tofnvestment rallo and inital costs. The Justice Department also continues to seek funding from other agencies (GSA and DOE) to accomplish energy saving projects and ecergy audits.

\section{Energy Savings Performance Contracts}

The Buresu of Prisons nas extered into a Cooperative Reserarch and Development Agreement (CRADA) with the Nacongl Renewable Energy Laboratory and Industrial Solar Technology, Inc. The CRADA is administered throngh the Construction Contracting Section of the Cetral Office. The end result of this CRADA will be an entergy savings perfornance contract The ESPC will be utilized for the domestic hot water provided at several locations within the Federal Correctional Institution, Ptoenix, Arizona. In order to verify savings of this ESPC, meters will be installed to measure the amount of energy delivered with consideration givent to the cost of acquir'ng this tenergy from the local vility provider.

\section{Demand Stde Management}

The Federal Burean of Investigation J. Edgar Hoover Building (JEH) and the Maris Justice Building currently participate in a PEPCO load curtailment program. The Min Justice Building and JEH buildings also continue to participate in PEPCO's rebate program. The Bureals of Prisons has a number of institutions that have been able to rective equipenent and materials ax discounted prices through major utility conparies throughoet the nation. Other institutions have received utility audits aimed at the corservalion of particuler foels. The Bureal also has implemented efforts to porchase "spot gas," resolting in tonnetary savings.

\section{Vehicles}

The Jostice Departient vehicle fleet consists of law enforcement, surweillance, or emergency and special velicictes that are exempt from the requirements of this section. There are 30 vehicles within the flet that are fueled by M85 or compuressed natural gas and $S$ electric vehicles used on a fintited basis. The vehicles were leased through GSA's Interagency Fleet Managentent System on a test basis to evaluate the future possibilities of alternative fuel vehicles as law enforcement assets. Due to the unique cbaracteristics required for fleet law enforcement vehicles, alternative fuel vehicles do not meet the Department vehicle requirements to be in any sigaificant number at this time. The Department continues to participale on interagency committees and symposiums for allernative fuels and keeps abreast of any adwancements in allernative fueled vehicles for posstble laclasion in the general fleet at a later date.

\section{Enviromenental Activities}

The Departmeat is consistenly aware of entironmental matters as they relate to energy conservation activities. Where asbestos is present during energy retrofits, it is handed according o curcert safety regulations. Enginzers in the Main Justice Building are proceeding to oblain certification in the handling of chlorofluorocarbons from GSA.

\section{Energy Management Cortact \\ Mr. Jim Shivar \\ Federal Energy Program Manager \\ U.S. Departirene of Jostice \\ Aerial Rios Builöing, Roon 2211 \\ 12th and Pentsylvania Avenuse, NW \\ Wasbington, DC 20530}

Phon: 202-616-2415

Fax: 202-307-1874 


\section{DEPARTMENT OF LABOR}

Enercy Efliciency Pertormance and Implementatton Strategies

In FY 1994, the Department of Labor reported a 4.6 percent increase in buildings consumption to Bto per gross square foot compered to FY 1985.

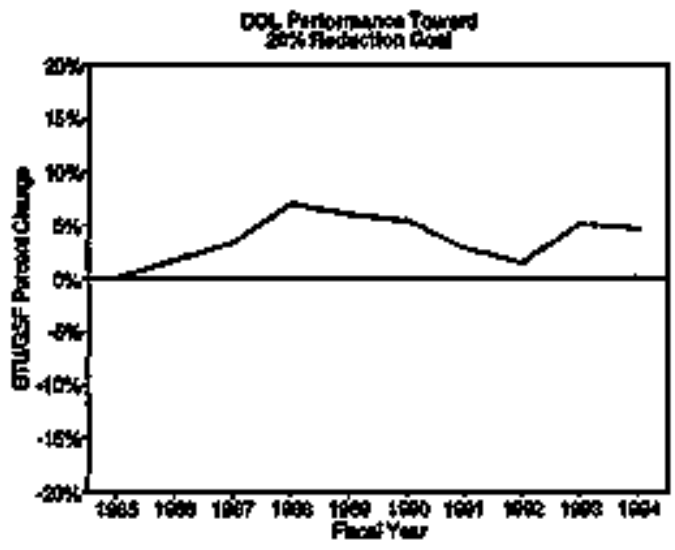

The component agencies within the Labor Department energy venagernent program ara: the Eurployment arit Training Adiministration Job Corps Centers (JCC). located througbout the country, the Fances Perkins Building (FPB), which is the DOL headquarters in Washington, DC, and the Mine Safecy and Fealth Administralton (MSHA) Training Academy in Beckley, West Vrginia, and the Approval and Certificalion Center in Triadelphia, West Virginia.

In FY 1994, DOL focused on the installation of energyofficientlighting and lighting controts to complete those known energy saving opportunities for lighting at FPB, its largest building. In this regard, GSA replaced the T12 lamps and ballasts wilb a variety of T8 models in all lobbies, corridors, offices, and lavatories. To complement GSA's efforts, DOL, inst:lled octupancy sensors in common-use areas which are sporadically osed. DOL also began installing ocenpancy sensors in the 1,000 individual of fiees tinroughout FPB. To date, FPB lighting retrofits save almost. 16 billion Btn of electricity each year. Finally, FPB began converting the 150 and 250 watt iricandescent lamps in the exterior overhangs to 52 wat compect aluorescent units, and will finish installation during FY 1995. Since all the known lighting retrotits will soon be completed, FPB will redirect efforts to those entrgy saving projects identifred in the energy audit cenrettly underway.

Over the next few years, DOL plars to relbeate 9 JCCs and boild $12 \mathrm{new}$ JCCs. DOL estimates that the increased size of the relocated JCCs and the new JCCs will increase DOL's total GSF by 16 percent but only increase our overall consumption by 11.2 percant as compared with FY 1985. The very moderate increase In eaergy consunption is schieved by applying all Federal eacrgy efficiency standards to new construction and major rehabilitation projects.

DOL began two comprebensive energy atudits during FY 1994 at the DOL Headipuarters facility and the Gtenumit JCC. These two facilities represent 11.5 percent of DOL's total gross square footage $(1,800,000$ and 206,821 GSF, respectively). These facilities were selected for this first audits because of their known energy saving potential. In the foture, comprebensive audils will be prioritized using the results of the survey requited by section 302(a) of Execulive Order 12902.

DOL facility managers also worked to reduce energy waste while maintaining acoeptable tentent coonfort levels. Staft reminded terants to turn off their ltghts overnight (Ltghts-Out Program) or antomatically "set-back" lights and fans during unoccupied hours (some Inb Corps Centers) and addiressed energy-and conservalion-related issues at periodic tenant advisory metings (Frankes Perkins Building).

The DOL Fuel Efficiency Outreach Program includes ride shartng activities (a carpool locetor and parting program at Frances Perkins) and employes atwareness programs sponsored by GSA, local govemments, and transit authonities.

\section{Trainlng}

Several Energy Managers from DOL parteipated in the Federal Energy Maragentent Program's Water Conservation and Federal Energy Maragement workshops.

\section{Funding}

DOL completed several energy conservation projects in FPB which use a combination of agency funding, GSA energy funds for delegated buildings, GSA capital inproventent funds, and/or ntility rebates. Agency futods from MSHA improved energy effictency by enthancing the current preventive maintenance strategy to include: (1) caltbpating the electrtc bot water tanks and the fan coil unils for the dorms, (2) sealing all the skylights, and (3) calibrating the energy management system once weekly. The JCCs did not have agency funds available for energy conservation projects separate from repair and alteration funds. 
Demand Side Maragement

DOL and GSA used the demand side mangement services of the local utility, the Potonac Electric Power Compary (PEPCO), to reduce the Federal expenditure of the major ligbting retrofit and one occupancy sensor retrofit in FPB. PEFCO paid for 25 percent of the major lighting project and 37 percent of an occuparcy sensor project for a total investment of $\$ 884,000$. These two retrofits should yield 8.7 billion Bto of energy savings each year.

JCC also reviewed the demand side management programs offered by ubilities aroud tie conntry. Lack of funting for projects in FY 1994, however, made JCC mable to take advantage of these opportmnities. To overcome fumding obstackes, ICC is pursming the use of third party tingncing througb etergy savings performance contracting and is preparting project proposals for the Federal Energy Efficiency Fund.

\section{Vehides \\ The DOL velicle fleet consists of 3,782 GSA Interagen- cy Flet Management vehicles (FFMSs), an undetemined nimber of privately-0wned vehictes, 161 agency-owned velificles (AOVs), and I8 commercially-leased vehicles. During FY 1994, DOA. decreased its inventory of GSA IFMSs by 56 vehicles. Fewer vehlcles did not, however, reduce fuel consumption overall; in fact, vehicte fuel consumption nose 0.1 percent as contpared to FY 1993 to 369.6 billion Btu.}

Toconserve wehicle fuel, DOL drivers employ the fuel efficient driving techniques recommended by $\mathrm{DOE}$ and GSA and perfomm rontine maintenance on the vebicles. Thus, the FY 1994 consumption total is 8 percent less than the fuel consumed in FY 1991. DOL expects to achiews the 10 percent reduction goal durtng the next fiscal year.

The cumber of alvernative fuel vehicles ( $\mathrm{AFV}$ ) increased to 7 percent auring FY 1994 as a proportion of DOL's comblned total of GSA IFMSs, AOVs, and commercially-leased vehicle Inventory. All AFVs are a part of the GSA IFMS group. The majority of DOL's AFVs are flexible-foel cars (275) which use ejther

(1) a mixture of 85 percent methanol and 15 percent gasollne,

(2) a mixblare of 85 percent ethanol and 15 percent gasollne, or

(3) 100 pencent gasohol during the year. Four of DOL's AFVs ane dedicated-fitel vans which use compressed naturad gas.
Environmental Activities

DOL drafted a Secretary's Order on the "Procurement and Use of Environmentally Preferable Products and Services," which was circutated for conment to al] the comportent agencies in the Department Anrimg FY 1993. The proposed Secrelary's Onder will estabtish a program in DOL for a costeffective procusement preference program favoring the purchase of products and services that maximize energy and water conservation, use recycled and fecyclabte products, minimize waste, vilize alternative fuels, and are less hernful to human health and the enviroment in their use and disposal.

It will also requite that DOL agency heads include in acquisjion ptarming for all agency procusement actions. and is the evaluation and awerd of contracts, life cycle cost and enviroumbental preferability, and develop and tmplement an agency plan for energy conservation through changes ip procurement practices, invesiment in energy efficient technology, and reduction of demankt.

Gnidarce concenting the various regulations, intitiatives, and procurement actions associated with the preference for environtmentally preferable procurement actions will be developed during FY 1995. Cumendy, DOL agencies received gtidnnce on procurement of Exergy Star compusers, rexycted paper, and recycled toner carridges.

\author{
Energy Management Contact \\ Ms. Maggie Carson \\ Office of Facilities Management \\ U.S. Department of Labou \\ Room S-1521 \\ 200 Constitution Avenut, NW \\ Wasbington, DC 20210 \\ Phone: 202-219.6434 \\ Fax: 202-501-6886
}




\section{DEPARTMENT OF STATE}

Energy Enfokency Petformbance and Implementation Strategies

In FY 1994, the Departutent of Stale reporidi fon incrase in buldings energy of 6,4 percent in Btw per grass square foot compared to FY 1985.

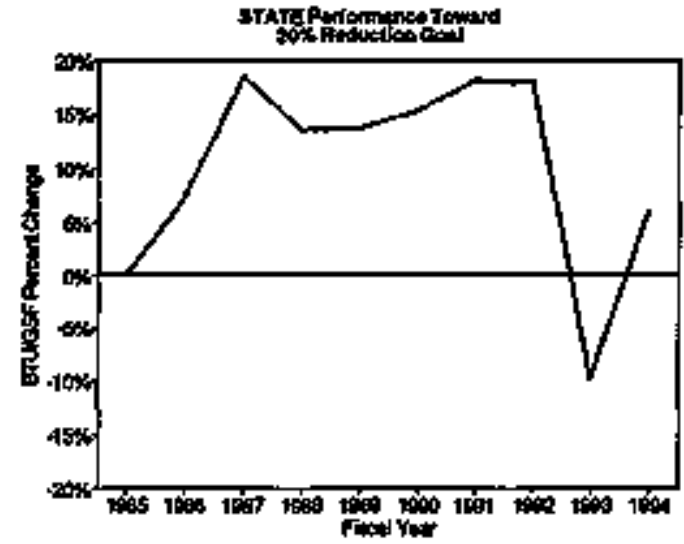

The Department of State activated its Energy Management and Conservation Plan in 1993 to met the FY 1995 and FY 2000 epergy management goals. The Department of State's overall strategy is based on the elements of its Energy Management and Conservation Program. Highlights include the following:

- Establishment of policy standantizing the purchase of energy savings products and adoption of energy effictent building operating guidelines and procedures. Builking Managers will acquire energy efficient motors for replacement of failed tinits and install T-8 iluorescent tubes and etectronic ballasts with specular reflectors where ecortonically feasible. In addition, instalbtion of conpact fluorescent and LED lighting alternatives in place of existing insandescent fxumes will contime, where applicable.

- New construction and repovation projects in domestic buildings will consistenuly include energy officient lighting alternalives as a standerd design element

- Procurement of Energy Star computer, prineers, and fax equipotent In addition, equipment acquisitions inchude consideration of energy conserving technologies as they become known, onderstood, and are marketable

The State Department requires installation of energy efficient goods and products which are proven to be cost-effective, pursinent to the requirements of the Federal Acquisition Regulations. To the extent praclicable, the
State Department also requires vendors of goods to provide appropriate data that can be used to assess lifecycle coses of each good or product, including building energy systems components, lighting systems, office equipment, and other energy using equipment. GSA and commencial verdor literature and catalogues which highlight energy effictent goods and products are regularly received. The State Department regularly evaluates these items for energy efficiency and cost for possible application in it's buildings.

When the State Department is responsible for new Federal construction, it generally involves occupancy by special use domestic and intenational functions, (i.e, computer centers, training centers, embassies, and overseas residences). Adherence to entergy efficiency standards is routinely toted in anchitectnrayengineering (AV) contracts, which include the development of specifications for the design and construction of Departuent of Stare-owned facilities. The AVE firm's compliance with the energy efficiency requirements is reviewed and monjtored as part of the normal design and constuction review process.

The Department of State bas ridesharing information available to assist personnel. The State Department has been inwolved to the Washington Metropolitan Council of Governments network to expand and enbance the ridesharing eftort. The State Departmeat's parking program promotes carpools and ranpools in the distribution of permits in accordance with the Federal Property Management Regulations. Parking permits are issued to renpools auteriatically.

\section{Training}

The Stale Department had one senior manager credentialed as a Certified Energy Manager (CEM) through the Associntion of Energy Engineers certification process. PJaus call for additional managers to be certified in the next few years. In addition, building management personnel will receive relevant instruction on energy management topics. Personnel will attend individual courses targeting tife-cycle cosling, lightios, and other teabnokogies and fundamentals of energy management avaliable through the Association of Energy Engineers and other sources. Staff will also attend trade shows and seminars to keep current on relevant technology and energy management fundamentals.

Funding

Fundiug requests for energy conservation retrofit and capital esquipment replacement are included in the State 
Departinent's budget process. Projects are prioritized in order of emergency, life and fire safety, mission, operation, or maintenance necessity. Consideration is given to Hife-cycle cost effectiveness, eqpipment condition, and savings-to-investment ratios.

\section{Fnergy Savhgs Performance Contracts}

The Department of State has not actively sought ont the services of energy saviogs performance contractors as our current building inventory is not genterally conducive for such initiatives. In the near future, the Main State Complex in Wasbington, DC, is scheduled for a complete renovation that will spen 6 to 8 years. Therefore, there remains only 3 years to recover costs and profit through energy savings performance contracting payment terms. Doe to the shot return on investment time periods and the complexity of energy savings perforrinino contracting, contractirs have expressed nore interest in utility rebate prognams where a rebate is assigned to them for paymeat in lien of telying oa energy savings for payment.

\section{Demand Side Marnagennent}

The Department of State seeks out and takes advantage of all rebate and incentive programs offered by local ubilities and energy service providers wherever avaliable. Eligible rebates in excess of \$1.6 million have been flled and approved for the Potomac Electric Power Company (PEFC) rebate program in the Districe of Columbia ptior to its recent termination. The agetsy works with PEPCO in butldings in Maryland jurlsdictions, Virginia Power in Virglnia, and ulitities in New Hanupsiine and other States wo identify and parsue energy conservation opportunities (ECOs). Contimued tnvotvement in the DOE FEMP audik program will be belpful in identifying ECOs for inclusion in new or succeeding lease negotiations between lessors and GSA.

The agency participates in the PEPCO Load Cuntailment Program for the Main State Complex, as one of the areas largest curtilers. Main State regularly reduces demand approximately 2,550 to 3,000 KW per curtailment call, which results in a credit of between $\$ 23,000$ to $\$ 28,000$ for each event

\section{Vehicles}

The Deparment of State is exempt from the reponting recuirements, as the number of domestic vehictes falls below the reporting threshold of 300 vehicles in the domestic fleet, when special purpose and law enforce. ment type vehicles are removed from the overall composition. However, be agency acopined six alternative foeled vehicles (15 passenges van type) from GSA and is also using a methanol fueled wehicle (4-door sedim) provided by GSA.
Environmental Activities

The Department of State recycles lighting ballasts through hazardous waste contractors and disposes of flucrescent mbes it accordance with hazardows waste removal standards and procedunes. Oils, solvents, and: paints are recycled by the hazardous waste collection coutractor. The Depertment of State recycles paper, gless, aluminum end steel cans, as well as polystyrene used in the cafeteria operation, all on a daily batis.

Energy Manogement Contact

Mr. Ricbard T. Arlburs

Energy Manager, Facilities Management

and Support Services

Department of State

A/OPR/FMSS

2201 C Street, NW

Washington, DC 20520

Ptone: 202.647. 8970

Fax: 202-647-1873 


\section{DEPARTMENT OF TRANSPORTATION}

Energy Eficiency Performinnes and

Implementation Strategfes

During FY 1994, the Department of Transportation reported a 10.1 percent redaetion in buildings consumpton in Btu per gross square toot compared to FY 1985.

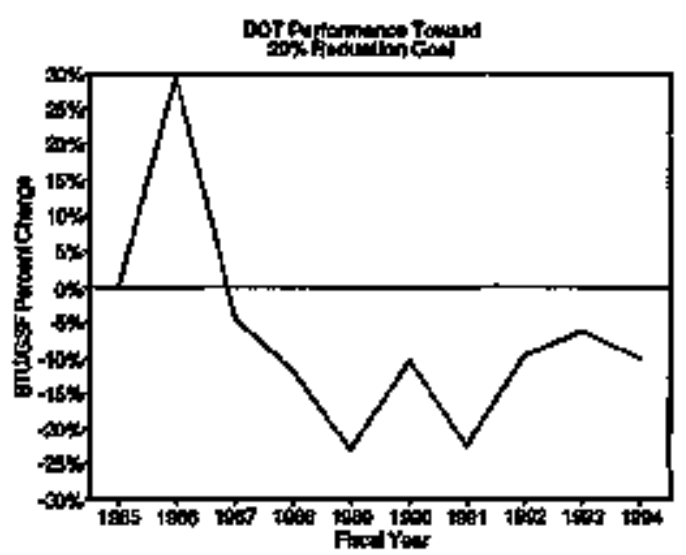

Due to the decentralized structure of DOT and the varied types of facilitics and programs in cach of the operating administrations, an independent plan was developed by cach and consolidated for submission to the DOE. The Departmenc's Frergy Management Implemeotation Plan was revised in December 1993 to include the requirements of the Energy Pollicy Act of 1992. This plen will be furber revised in the saring of 1995 to include the prowisions of Executive Order 12902.

Energy surveys and energy conservation measures which were completed is FY 1994 are tisted below:

- The Office of the Secretary has completed the first phasc of atwo-phase retrofit of existing flworescent Extures with T-8 lamps, electrontic bailasts, Jeflectors and new prisuntic lens at DOT hetudgarters in the Nassif Building. Thts year, 14,000 fixtures were completed which is expected to save $\$ 200,000$ annually.

- The United States Coast Guerd (USCG) completed 32 energy conserving projects at a cost of $\$ 1.5$ million with a projected annual savings of $\$ 153,000$. The major projects included $\$ 256,000$ for the Icplacement of windows at the USCG Actenny, $\$ 180,000$ for a boiler replacement at Support Center Now York, $\$ 175,000$ for HVAC system replacetutete at Air Station Dearoit, and $\$ 100,000$ for an HVAC automation project al Group Philadejphia.

- The Federal Aviation Admimstration (FAA) has completed an energy survey of three of the highest energy use boildings at the Technical Center, Atlantic City. New Jersey. Three separate survers bave been completed by local utilities in FAA's Soutbirest Region.

- As part of their \$65 million renovation of the Farbanks Building, McLean, Virginit, the Foderal Highway Adninistration has installed a variable tir wolume system which is expected to significantly reduce the energy reguired for heating and cooling.

- The Maritime Adnutaistration has completed the first phase of the three-plase upgrade of the Merchant Marine Academy's heating plant. This $\$ 10, \$$ miltion profect is expected to reduce the use of fossit fuels for heating by 33 percent. A project for the instillation of energy-efficient windows was conpteted at the Mercbant Marine Academy at a cost of $\$ 900,000$. Several major buildings at the academy have been re-roofed and re-insnlated, impuoving enetgy efficiency, at a cost of $\$ 12$ million.

- The Research and Special Programs Administration is continuing with relighting efforts at the Volpe Nattonal Transportation Center. This project indededes T-8 Imps, electronic ballasts, specular reflectors, occupancy sensors, and replacement of incandescent lamps with compact fluorescent lamps.

- The Saint Lawrence Seaway Development Comporation has completed the replacement of approximately 85 percent of the windows with more energyefficient double pane windows.

Operation and maimcenance continue to be emplassized as a major compontent in the effort to achieve energy refuction goals. Basic procedures include securing HVAC eçuipantent as well as unnecessary lighting duxing uncecopied hours. The FAA even reduces airpont ligbting when practical, without connpromising safety of aircraft operations. New procedures, products, and contracting methods that would facilitate more efficient operation were distributed through the Departmental Energy and Water Manggennent Committee.

Where practicable, facilibes with access to naturit gas are converting from foel oil to gas or to dual fuel capability. The Support Certer in Govemor's Island, New York, has completed the cotversion from fuel oil to nztural gas which reduced oil consumption by 1.6 million gallons per year. The Reserve Training Centex 
in Yorktown, Virginia, is pursuing conversion from oil to netural gas as described below. The Merchant Marine Academy and the Tunterifairtbarks buildings use interuptible natoral gas service with fuel oil beckup in their doal fuel boilers.

The Department bas an ongoing ride-staring program with a mistimun occupency reguirement for a parking pernit at Headquarters buildings. Over 290 parking permits have been terminated and 1,227 people bave left the parking system at Headquarters as a result of this program.

\section{Training}

The Department has condected a trailing survey of all facility energy supervisors and energy managess wilhin the Department. The purpose of the survey was to establish what the training level ts and what the needs are. During FY 1994, 2 people were trained in Energy Savings Performence Contracting for a total of 26 people from the Department. Several people atterded Federal Energy Deciston Screening (FEDS) software training sponsored by DOE. A 1-day course on electric rate. structure and energy conservation was conducted by Florida Power and Light Company for 23 FAA employees.

\section{Funding}

An accurate identification of the total furding specifically dedicated to energy conservalion actions is not available. Many of the energy conservalion actions are inseparable parts of major renovation or expansion project. Some strall, quick pagback, projects are funded locally as part of the operations and maintenance function. Progress is being made in baving energy conservation projects identified in the budget process.

\section{Enery Savings Performance Contracts}

The implenentation of ESPCs is decentralized within DOT. It is the responsibility of the individugl operating administrations to develop and award ESPCs, and the management stnicture is the same as that for the energy conservation program. At the present, DOT does not bave any ESPCs in place. The Federal Aviation Administration is currentily firalizing a proposal for the instrallation of a chilled water and ice thermal storage system at the Aeronautical Center in Oklahoma City.

The major problem implementing ESPCs at DOT is the large up fromt investment in time and training for procurement and technical personnel while staffing is being reduced. Ober conceras include the reluctance by some contracting officers to enter into such contracts without clear anthority in the Federal Acquisition Regzlations.
Demand Stde Management

The use of utility DSM incentives is strongly encouraged throughoat fie Department. DOT has a project underway for the retrofit of 13,500 fluorescent 5xtures wilh T-8 tubes, electronic ballasts, and neflectors at the Headcjarrters Nassif Building. The Potomac Electric Power Compeny is expected to provide a rebate in excess of $\$ 500,000$ for the project. The Coast Guard Academy is negotiating a contract with Connecticut Light and Power for a full facility energy audit.

\section{Vehilcles}

The Department developed a ptan to meet the 10 percent reduction in consumption of gasoline and diestl fuel by FY 1995. The goal will be met by acquiring more efficient vehicles, driver awaresess trairing, and close examination of vebicle use.

The DOr motor fleet is made up of 8,686 general purpose vehicles. Approximately 93 percent of these vebicles ane obtained through the Genteral Services Admin'stration's (GSA's) Interagency Flet Management Systems. The olber 7 percent are agency-owned or commercially-leased vehicles and are located primarily in Alaskar.

DOT met the goal for FY 1994 for teplacetrient of 276 ( 33 percent) of the 798 vehicles (sedans and ligbt micks) eligible for reptacement based on age and metropolitan area. Currently, there are 652 AFVs in the fleet which includes all of the Headquarters extecutive fleet vehicles. DOT will continue to work with GSA to obtain the maximum number of AFVs for the fleet.

Environmentil Activities

FAA bas developed a techtical guide entitled "Production Phasecut of Chlorofluorocarboss (CRC) and Halons Pursuant to Title VI of the Clean Air Act Amendinents of 1990 Assessment Report." The guide was published in May 1994 and includes portablo balon rechargeirecovery umits and recoveting, recycling, and recharging units for CFC-Rl1.

\section{Rnergy Management Contact \\ Mr. George Kuelin}

Administrative Services Policy Division

U.S. Departmert of Transportation

400 7th Street, SW

Washington, DC 20590

Phone: 202-366-4243

Fax: 202-493-2006 


\section{DEPARTMENT OF THE TREASURY}

Energy Bficiency Performance and

Implementation Strategios

Dutung FY 1994, the Department of the Treasury reported a 46.4 percent increase in buirdings consumption in Btu per gross square foot compared to FY 1985.

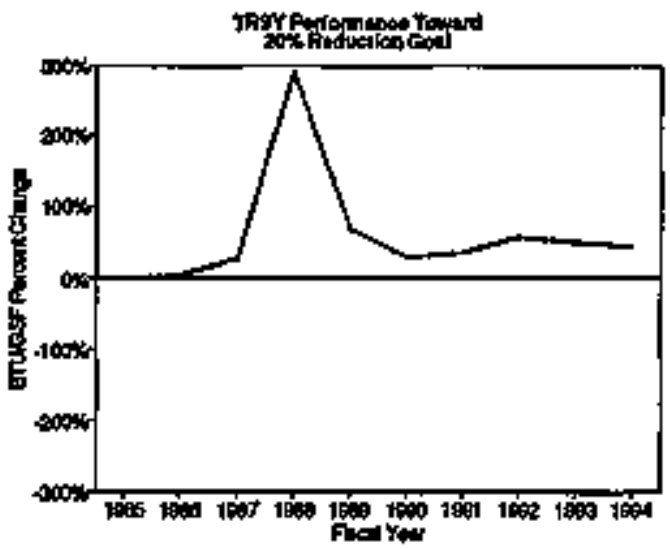

In 1994, the Department of the Treasury revised its Departmental ditrectives and policies to meet legislative and Presidential goals and objeclives. The Department provided greater latiuxie to its bureaus to adopt those incovative approaches initlated by otber Federal Departments and agencies. The Treasury Department also has encouraged its burcaus to revisit cutrent buseas polictes and procedures to ensure they are up-lo-date and consistent with Departmental and the mandated objectives.

Bureaus execuled various aspects of beir energy managemept plans to meet the FY 1995 and prepare for the FY 2000 gaals. Plans emphasize:

- paticipation in public ulility company deanand side management programs;

- Iraining for energy managess and related personnel;

- acquisition of energy effictent goods, equipment, and services;

- employing energy savings performance contracting at selecked facilities to gain the economies accruing from private sector involvementit;

- experimentigg wilh the use of altematlve fiteled vehicles and snaller vebticles in a variety of nisssionrelated situations; and
- maximizing the use of all available technical, firancial, and engineering expertise available to the Department and its bureaus.

The Interal Reverue Service (IRS), the Treasury's largestenergy user, reported that its GSA.delcgaled sites completed Energy Management and Conservation Gojdelines and incorporated then into building operations plans. These guidelines set schedules for startup and shutdown of HVAC equipment. A study on the stanus of the energy impact on the modernization of IRS Service Centers was conducted.

Power consumption in the all-electric Bureau of Public Debt factilty at Ravenswood, West Virginia whs reduced to $\mathbf{4 7}$ percent of FY 1985 levels. At the fracility in Parkersburg, West Virginia electrical consunuption dropped mote than 12 percent from FY 1993 to FY 1994 and electrical use has dropped by over 25 percent since peaking in FY 1987. These reductions were achieved in spite of increases in building poputations, elevator usage, additional HVAC, and new autormated data processing equjipgent.

In FY 1994, the Foderal Law Enforcement Training Center was working on or had completed energy impowement projects involving HVAC improvenents, ctiling and lighting projects, energy-ficicient bollers, entrgy-efficient windows, siding improvements, and electrical rethovalion projects. Similar projects are being funded during FY 1995 at many localions at the Training Center.

\section{Tralning}

The Treasury Department bureaus bave on-going programs where employees are sent to seminars or courses on energy efficiency and management or are trained on the job to respond to energy conservation Intilitives. The bureaus reported training 21 persomel during FY 1994.

\section{Funding}

The IRS expended $\$ 3.6$ mitlion for energy-relared projects in FY 1994 and bas made plans to perform additional energy efficiency projecss at its focilities in FY 1995. Among the FY 1994 expenditares were $\$ 90,000$ for lighting modernization projects, $\$ 190,000$ for chlller' replacement projects, HVAC repsir and replacement projects at $\$ 210,000$, and EMS system instaltation projects at \$1.2 million. Proposed project expenditures for FY 1995 total atmost $\$ 2,2$ million. 
Funding for energy-related projects at U.S. Mints in FY 1994 was as follows:

- Philladelphia - $\$ 680,000$,

- Denver - \$206,400; and

- Sas Francisco - \$82,800.

Projicted funding at U.S. Mints for cnergy-related projects in FY 1995 include:

- Philadelphía $-\$ 559,000$,

- Deaver - \$355,000,

- San Framkisco - \$400,000;

- West Point - $\$ \$ 00,000$; and

- Fort Knox - $\$ 30,000$.

\section{Energy Savings Performmonce Contracts}

There hus ben a significant increase in the level of interest in and development of energy savings performence contracts in the Departuent during FY 1994. Treasury bureans reported efforts to develop four such projects in 1994. In FY 1995, Depertmental Offices, Treasury's Headquarters Office, anticipates embarking upon a ESP contact tor electrical and other services in the Main Treasury and Annex buildings. It also expects to use the completed projects as exhitits in its "showcese faciltites." The altempt to institute ESP contracting at GSA-delegated facilities continues to be unsuccessfill, The dial management of these facitities (Treasary burean and GSA) presents a bartiter.

Demand Stile Minnagement

Treasury bureaus continue to work with kcal utitities to tike advantage of DSM programs. The Internisl Revenne Service, Financial Office of Thrift Supervision, Bareall of Engraving and Printing, the U.S. Mints, and the U.S. Secret Service took advantage of these programs jn FY 1994.

Vebicles

Treasury bureaus bave taken steps to increase the efticiency in the use of mator rehicles. The U.S. Customs Service hes diversified its fleet over the past several years, reducing its larger Class IV vehicle fleet. The bureau also has implemened the Vehicfe Informaton Management System which tracks vehicle usage and maintengance, inchuding fuel consumption, mileage, and indicators of pocr performance. Vehicle-to-emplofee ratios are used to assign vebicles to specific duty positions within the bureau and tirve resulted in the disposal of ojder, less econoutical vehicles. The Bureau of Alcobol, Tobacoo and Firearms ofistibutes inforinetion on the conservation of fuel to vebicle operators through the publication of newsletters. Official mileage in personal yekicles has fopped within the Bureas of Pubtic Dest.

The bureaus bave also indicaled a willingness to acquito alternative flucl valicles (AFV). The Bureal of Alcohtor, Tobacos and Firearms axquired ibrec dixl-fixled AFVs, for use in the Washington, DC, and Lanitsdale and Pittsburgh, Pesnsylvania areas. The Federal Law Enforcernent Training Center (FLETC) will receive four compressed ratural gas vehicles from GSA. Three FLETC-owned whicles, two high-speed pursuit vebicles and a minival, are being converted to duel-fiveled vehicles. An AFV tueling station has been installed onsite at FLETC's headquaters in Glynco, Georgia. Because most Treasury vehicles aro law onforcement vehictes, it is important that the Enforcement bureaus address the Executivs Order requirements without compromisising mission effectiveness.

\section{Environmental Benefits}

Treasary Directive 75-06 requires Treasary bureasas to ensure all facilities are covered by a program lo control eovinonmental pollution. The programs include environmental surveys of factilities, plans to correct identified problems, beadgeting for necessary respources and training employees involved in environmental programs. The reports provided by Treasury bureans indicate the adoption of a variety of means to comply with the Treasury directive and address environmental concerns.

Energy Management Contact Mr, Bill McGovern

Asst Director of Energy Programs

Office of Management Support Systems

U.S. Department of the Treasury

Mgin Treasury Annex, Rocm 6140

1500 Pensylvania Avenue, NW

Washington, DC 20220

Phone: 202-622-0043

Fax: 202-622-2273 


\section{DEPARTMENT OF VETERANS AFFAIRS}

Einergy Eilleiency Performance and

Implementation Strategles

During FY 1994, the Departiment of Veterans Affairs reported a 13.2 percent reduction in beillings consumption in Bun per gross square font compared to FY 1985.

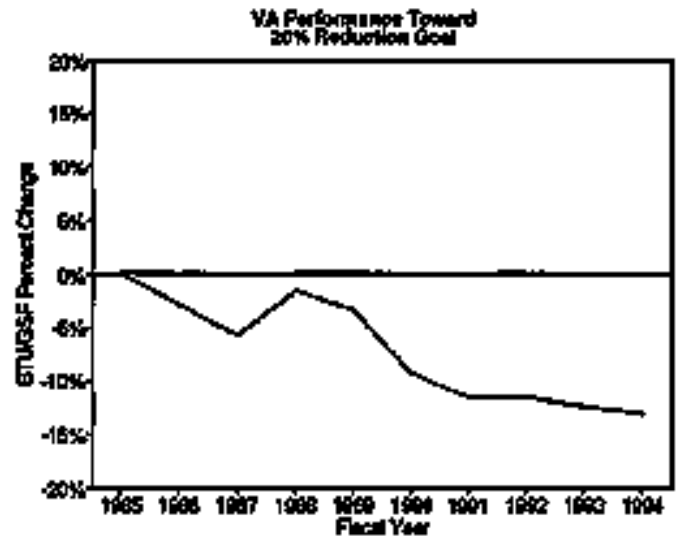

The Department of Veterans Aftieis developed an agency 15-year plan for FY 1985 to FY 2000 and submitted it to DOE. The implementarion of this ptan wirl help the VA to meet the requirements of NECPA, EPACT, and Execulivs Order 12759.

As part of the VA's plan to inplenent Executive Orter 12759, each inedlcal center has been assigned a target goal in Btu per gross square foot for FY 2000 that it is required to meet. Energy consumplion at the medical centers is monitored, and progress towand the goal is published ąurterly in energy management reports which are distributed to each medical center.

During FY 1994, the VA has continued to concentrate beavly on the research and development of cost-effective methods to reduce overall electrical consumption and associated costs. Increased denands to satisfy the needs of modern medical care bave resulted in an increase of electrical consumption (to kilowatt hours) of 29 percent compared to consumption in FY 1985. The following melhods have been implemented to reduce this increase:

- The design criteria for all new constraction and retrofit projects now inclndes the use of the most etergy-efficient lighting fixtures.

- New comstraction is designed to cperate at an electrical power factor of 0.95 or higher.
- Energy management and control systrens wilh dinect digital comtrols ane specieved as part of new crnstruction, and retrofit of HVAC systems.

The VA bas one cogeneration plant that it owns, operates, and maintains, and the VA is cerrently evaluaring the costeffectiveness of using themint storage systems at many medical centers.

Building retrofit projects inctuds the installation of energy managentent control systems, modifications of the existing HVAC systems, steam trap replacement, impovement of boiler efficiency and lighting and power systems, and instalkation of additional insulation and storm windows.

\section{Training}

VA conducted a nationwide survey to determine bow many energy managers ar the medical centers are qualified as Thained Energy Martagers under the requirements of EPACT. The survey results were subnitted to the Department of Energy, and it was detemined that many energy manages would need some additional of training before they could be qualified as Tralned Energy Managers. The Engipeeting Staff at the medical centers have been informed of the different courses they need to take and their availability in different regions. These contses are offered by the Association of Evergy Engineers in coxpertition with the Department of Energy. Many medical centers took advartage of these trainjing classes during FY 1994.

\section{Funding}

Funding for energy conservation retrofits and capital improvements was 59.05 million for FY 1994. Fumding of \$11.96 million for projects that have been approved by the Central Olfice for accomplishment of energy efficiency projects at the medical centers in FY 1995.

Energy Saving Performance Contracts Daring FY 1992, the West Haven VA Medical Center became the first Veteran's Hospital to award an energy \$vilgs perfomance contract. This $\$ 2.4$ million project, awarded to EUA Cogenex Corporation, is a 15-year contract The entire cost of the lighting sysem replacement and the cooling system installation, together with the maintenance of the new chiller exuipment, will be funded from rebate programs provided by \$outhem Connecticut Gas and United llluminating Compeny, as weil as from gaaranteed savings in energy costs acbieved over 15 years of operation. The medical center is tow reviewing an additiontal energy conservation 
project proposed by the contrictor. Other meitical centers are also evaluating this concept to accomplish their projects.

\section{Defmend Side Momagement}

The VA is actively participatiog in the utility rebate programs and has funded many projects doring FY 1994 at facilities that can participate in these programs.

VA has been working with Soothern Califomia Edison to develop an electricity saving program at the West Los Angeles VA Medical Center. The project would replace lighting and air conditioning equipment with much more efftcient systems. All project costs would be gaid from savings in electricty costs resulting from the new equipment. While cochnically not an energy savings performance coratract, the eadeavor replaces ineficient electrically-powered equipment and repaires no capital expenditure by the government.

\section{Vehicles}

VA did not purchase any alternative fueled vehicles (AFVs) during FY 1994. AFVs are generally teased through GSA. Alternative fueled vehicles and their fuel infrastructures are to be concentralted in the 22 nonattainment and 125 metropolitan statistical areas. VA believes that GSA will acoommodate the VA in those areas with leased vehicles when the infrasinuctures and AFVs become availahic.
Energy Management Contact

Mr. Rojinder P. Garg

Chief, Eucrgy Management Division (138C1)

U.S. Department of Veterans Affairs

Room 417 - LAF

810 Vermont Avenue, NW

Washinglon, DC 20420

Phone: 202-565-9353

Fax: 202-565-6012 


\section{ENVIRONMENTAL PROTEC"TION AGENCY}

Enorgy Eniciency Parformance and

Inapiementation Strategies

In FY 1994, the Envinonmental Protection Agency reported an increase in buildings energy of 36.0 percert in Bu per gross square fot compared to FY 1985.

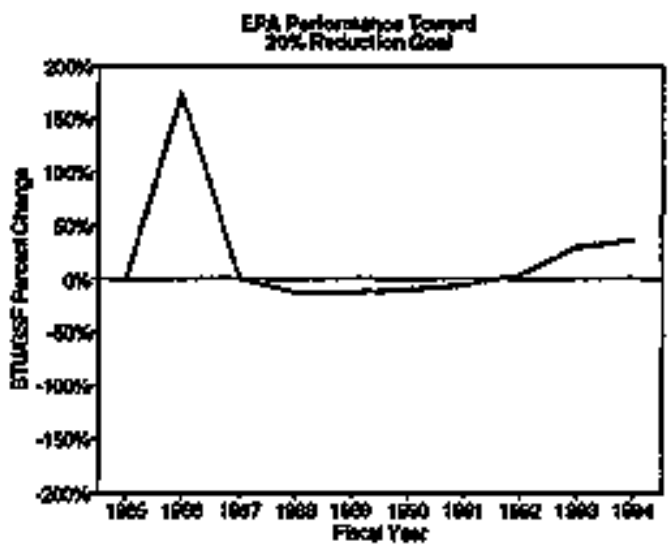

EPA's energy management program consists of three phases which fumction concurremly. During Phase I, sile-specific inforutition is collected from facilities. That information is evaluated to identify conservation opportunities for each site daring Phase II. The final Phase includes priorilizing, płanning, and implementing conservation projects. During FY 1994, EPA's efforts concentraced on researching baselute data, galhering facility information, establisbing program tools to a wd program development, and fissenination conservation information to EPA Energy Matapers to garner program support.

EPA has developed numerous tools to assist regional eacrgy managers with their conservation efforts such as an information clearinghourse and bodine to efficienuly disseminate infoumation on regulations, energy-efficient products publications, and conservation-rehated associaltions. Clearinghouse staf producod an awareness program guidance document to assist the regions in gamering conservation program support Additotoally, be clearinghouse publishes and distributes a quarterly nerssletter, Energy and Water Conservation News, which serves as a focal point to educate and inform EPA staff involved in conservation efforts. Several other key tooks have been developed to assist conservation efforts including a Sample Policy statenest for EPA factlities to adopt as a foumdation for their Energy and Water Conservaton Program, a revised Conservation Manual establishlog responstbilities and requirements for managing mergy and water resources in EPA facilities, and a datahase for tracking antit Endings from site visits.
EPA updated its building standards to emphasizo congy and water conservation. Additionally, EPA's program of requiremencs for newly consinuted Federal buildings requires adherence to 10 CFR Part 435 and curreut ASHRAE standards. Also, as a Green Lights Partier. EPA has agreed to design all new buildings with energyefficient lighting systems. Morenver, efforts continue to be mude to design pew iaboralories as showcase facilities highlighting state-of-the-ant energy and witter conservation technologies.

To demonstrals successtul conservation projects, several pilot projects have beet initioted and are in early stages of development, including:

- ECOP3 (Waterside Mall Energy and Water PublicPrivate Partnership). EPA's Waterside Mall Headquarters was selected during FY 1994 as an Energy Star Showcase Pacility. Builditing on the success of (ireen Lights, the Energy Star Butldings program focuses on profitable investment opgontunites using proven technologies. A staged approach prowides a strategic framework for making comprehensive efficiency upgrades. First, the lighting system is retrofitted with a high effeciency lightiog system; second, the building is recommissioned and tuned; third, the HVAC load is reduced; and fourth, the heating and cooling equipment is improved. So far, energy efficient lighing has been instalted in two towers of the facility, nearty 400,000 squane feet of space. The rest of the facility is scheduled to be retrofitted during 1995.

- Erergy-Efficient Laboratory Design-Annagolis Laboratory. EPA is evaluating the leasibitity of incorporating energy-efficient lighting, desiccant gas cooling, and fuel cell technologies into the Annapolis Laboratory building design.

- EPA's Anm Arbor facility began evalnating the fersibility and cost effectiveness of installing a desiccant conling system equipped with heat pumps to recover waste lost during one-pass air system operation.

EPA plans to implement a transit stbsidy program at is Wasbington, DC beadquarters tocation. Region 2 intpleznented a public transit fare subsidy program in October 1992. Presently, 800 employees recelvs reimbursement for their connuting costs ug to $\$ 21$ per month. Region 3 has operated an employee transit subsidy program since April 1993, which reimbursses 
employes \$45 per fiscal quarter for using poblic transportation. Due to financial cutbacks, however, this propram has been tomporarily been suspended. Region 8 perticipales in the Regional Transportation District "Eco-Pass" program and provtdes yearly bus passes to each full time permanent entployee. In July of 1993, Region 10 implemented a transit subsidy program which cales employees $\$ 10$ per month for public transportation costs.

\section{Training}

EPA has been engaged in and hosted numerous training events during FY 1994. Program staff regularly attended energy and thater oflservation or ferences and seminars, itcluding GSA's TEEM '94, the Natural Gas Cooling Summit, and the FEMP Water Resource Management training workshop. Progrem staff also regularly arranged product demonstration seminars with vartous vendors for EPA's engineers and archliects to keep them atreast of the most innovative tectinologtes. EPA also worksd closely with contract staff who are certified trained energy managers.

\section{Funditis}

For FY 1994, EPA's Enetgy and Water Couservation Program had a budget of approximately $\$ 1.3$ million. Nearly one-third of the budget was allocated to develoging program tools, 50 percent of the bidget went to energy efficient Hghting retrofits, and the balance was allocated among other conservation projects, facility audits, and technical and administrative support. In addition to the EPA's cestrally-mangiged Program funds, Regional Facility Managers had amthorlty foc appooving up to $\$ 75,000$ per facility project. While FY 1994 reporting did not capture all of these expenditumes, EPA will continue to research methods to more completely track these expenses. The Energy and Woter Conservation Program budget will be approximately $\$ 1.7$ million for FY 1995.

\section{Energy Saynjog Performance Contracts}

EPA has been woiking with the WatersidsMall facility's non-govemment building Owner to secure third party finamcing for a đesiccent cooling system for this facility. However, berriers inhibiting the use of thitrd party flnamcing and tncentives in the Federal sector still extst, making it difficult for EPA to use this incentive. To date, EPA has pot used energy savings performance contracimg or vilility rebats program füding or retates.

\section{Demand Side Mamagement}

EPA has not yet perticjpated in any vility rebata programs, but EPA's onergy coordinator has been wodking with an Interagency Energy Management Task
Force working proup to develop ways utlize these incentives.

\begin{abstract}
Vebicles
Approximately s0 percent of EPA's vehicles are leased from GSA. EPA has develoged a plan for replacing 444 owned and leased vebicles trom FY 1994 to FY 1998, which will constlute approximately 78 percent of the fleet of light outy vehicks assigned to EPA Regions, lakeratories, and other in-house activities. This was accomplished by negotiation of aggressive rephacement plans with each regional EPA Motor Vehicle Coordins. tor. Of EPA's total fleet of 1,190 vehicles, 134, or 11 percent, are altenative fivel vehicies. Additiongl pints include accpisition of electric pehicles from Fermsyivania Electic Power Company by Region 3, and conversion of at least two new vehicles to liquid propane gas by Reglon 6.
\end{abstract}

Atso, the EPA Headquarters Transpcrtalion Management Section is close to completing a computerized inotar vehicle operations database and tracking system which will provide detailed information reganding utilizaticn, maintenance, fuel consumption, and operation $c 0$ sts for cach EPA-cwned, GSA-leased, and commenctally-leased vehicle and for the fleet as a whole. This system will enable managers to pinpoint vehicles which are over. aged and more costly to operate, as well as vehicles which are under-used. EPA plans to implement a timely vehicle reptacement program, dowshing whib smaller, more fuel-efficlent vebicles and to reduce the fleet slze by elimination or consolidation of vehicles whtch consistently fail to actiteve minimum mileage goals for their type of use.

Energy Manggement Contact

Mr. Philip Wirdzek

Program Anlalyst

Envitonmental Protection Agency

PM-215, Rocm NEG Oth

$401 \mathrm{M}$ Street, SW

Washington, DC 20460

Phone: 202-260-2094

Fax: 202-260-8234 


\section{FEDERAL EMERGENCY MANAGEMENT AGENCY}

Energy Ethciency Performence and Implementation Strategies

In FY 1994, the Federal Emergency Mamagenent Agency reported a decrease of 22.7 percent of buildings energy in Biv per gross square foot contpared to FY 1985.

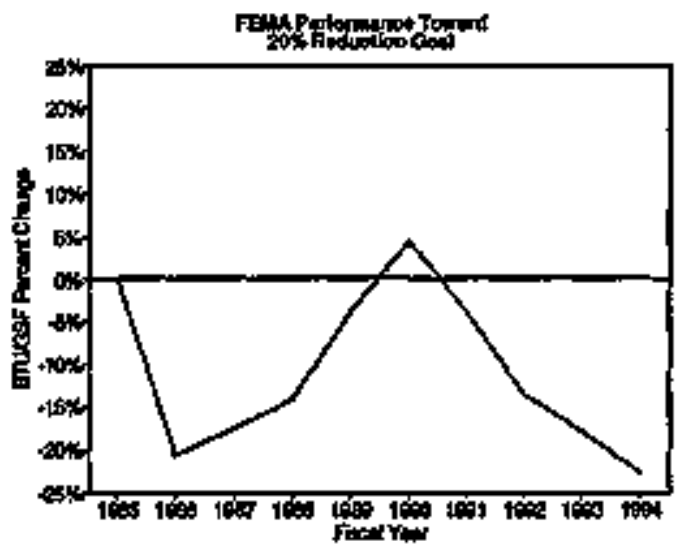

FEMA has tondertaken the following initiatives:

- developed explitit instructions to ensure that reports on energy management comply with DOE requirements;

- designated an Energy Management Conservation Officer to oversee FEMA's Energy Management and Conservation Program and to ensue that FEMA ts successfully meetipg its energy reduction goals; and

- developed plans for instaling energy-eficient measures in FElMA-controlled facilities that directly pay utility costs having an 10 year or less payback by the year 2005 .

Daring FY 1994, the National Einergency Training Center (NETC) in Emmitsburg, Maryland, replaced lighting systems in 20 buildings with high efficiency lighting systems to include all interrior and exterior lights. A combinglion of lights were used including fluorescent T-8 lamps with electronic ballass and 3 walt LED exit signs. Exterior site lighting was retrofitted with bigh pressure sodium inxures. The retrofit will save approximately $\$ 18,000$ annually in lighting cost.

Foture projects at the NETC inclnde the following:

- Installation of insulation on exterior walls and use of energy-efficient lighting and mectanical/electrical systems for existing structures.
- Implegentation of an Energy Managemeot System lo lachude demand monitoring, occupancy sensoss, and cycling of mechanical systems.

The plan for meeting the NECPA goals developed by the Special Facility Management Divition in Berryville, Virginia, includes three basic elemens: (1) to incorperate the latest energy conservation features and tectmiques in all new facilities consinucted at the Special Facility: (2) to inchude the batest energy conservation features and techniques in all of its equipment reptace. mezlt, mojor maintenamce, and major renovation proptects; and (3) to maintain all equipinent and systems that affect energy usage to ensure that they nemingin at or near peak efficiency at all times. This plan did not change for FY 1994, and no changes are expected for FY 1995. FEMA is plauning to apply for fumding from the Federal Energy Efficiency Fund to upgrade some factlity liphting systems. On August 10, 1994, FEMA staif met will a representative from $\mathrm{DOE}$ and obtained gtidance on how to apply for this fuoding.

An energy conservation project, the Area B Heat Rexovery System, was completed by the Spectal Facillty Management Division in FY 1994. It imvolved the replacement of a fuel oil fired boiler with an electric heat pump to provide beat and hot water to abont onethird of the Special Facility. The heat pump extracts waste heat from these buikdings and uses this to help generate beat and hot water, and thus oses electricily and wasts heat instead of fuel oit It has redinced the use of fuet oil by these buildings from a FY 1993 total of 87,500 gallons to a FY 1994 total of 8,600 gallons, most of which was used before the system was put on line. This project cost \$175,000; the expected savings should pay for it in approximately 3 years.

The Federal Regional Center, focated in Dentort, Texas (Region VD). is wailing for a recommendation proposal from the installer of the Region's Environtnental Mamagement Control System that will further increase energy efficiency and the conservation of fuel.

The Fêderal SupportCenter in Ohey, Maryland, replaced the electric meter at the facility to more efficienty track electric power consumption.

\section{Training}

FEMA identified sources of energy management training for our facility energy manager this fiscal year. Becaluse of be limbted amount of available training funds, priority was given to training which was necessary to maintain 
required employee certifications, and training for mainteance of critical site equipenent. Funds were not available for energy management training.

\section{Funding}

FEMA did not expend any significani funds tor energy conservation projects tis fiscal year. The Area B Heat Recovery System was funded primarily in FY 1992. The budget is limited and priotity has been on equipment repair, replacement, and capital improvement projects which are secessary to operate and maintain the facility. FEMA does not anticipate a change in tisis sibuation in the anear fiture.

\section{Energy Savings Performanco Contracts} FEMA did not participate in energy sayings performesnce contracts during FY 1994. Also, FEMA's progress lowards meeting NECPA goals is such that it is not anticipating the pursuit of these contracts at this time.
Demand Side Manongement

During FY 1994, the National Entergency Training Center in Emmitsburg, Maryland, received rebstes from the local Potomac Electric Power Company for its Itghting retrofils in 20 butildings. The rebates were availablo tor retrofis or new installations.

\section{Vehicks}

FEMA has a motor vehicle management program that ensures motor vehtcle drivers operate vehicles in a foelefficient manner. FEMA cperates a snall fleet of 207 vehicles and, therefore, is exempted from developing a plan to reduce motor vehicle gasoline and diesel consunption by 10 percent by FY 1995.

\section{Energy Management Contact}

Dr. Frederick C. Shoffier

Chief, Support Branch

Operations Support Directorale

Federal Emergency Management Agency

500 C Street, SW, Room 319

Washington, DC 20472

Ptone: 202-646-2636

Fax: 202-646-3524 


\section{FEDERAL ENERGY REGULATORY COMMISSION}

\begin{abstract}
Energy Eficiency Performance and Impiementation Strategias

In FY 1994, lite Federal Energy Regulaury Commisston (FERC) reparted a 80 percent increase in building energy consumption in Btu per gross square foot compared to FY 1985.
\end{abstract}

FERC revised its energy mantagement plan to promote energy efficiency and meet energy goals of both the Natiotal Energy Conservation Policy Act (NECPA) and Executive Order 12759. These revisious estiblish gentral exergy performance objectives for building operations. FERC undertook the following energy efficiency activities daring the year.

- Implemented and emphasized energy conservation awareness among building occupants

- Roviewed and updated building operation plans to ensure compliance witb energy guidelines

- Implemented no-cost and low cost eoergy conserva tion metbods

- Reviewed and implemented changes in agency operational policies, such as reduction of overtime ose of factlifies

- Monitofed energy usage in facility and analyzed constmption data

- Performed surveys to identify energy conservation opportuoities and improved building operational procedures

- Used cotside air for cocling when possible

\section{Trainhing}

As required by section 157 of EPACT, FERC energy managers received training in the area of energy efficiency and nomagenent This usinimg was developed and presented by the Association of Extergy Engineers.

Funding

FERC invested in small eterigy conservation projects during the year. Building conridors were delamped and incandescent light fixtires were replaced with compact fluorescent foxtures and lamps in restrooms. Futher investment in energy efficient retrofits and equipotent is not planned for the 825 North Capitol Street building due to the near expiration of the beildrog's lease and ptanned consolitation into a plew buidding.
Demand Side Management

FERC participated in the Polomac Electric. Power Company's (PEPCO) Load Curtalment Program and Oustom Rebate Program which pays customers for energy reduction projects such as lighting retrofits. These savings appeared as credits on utitity bills.

FERC continved working with the General Services Admintstration and its future building owner ko complete the construction of its energy efficient biilding. FERC's new building wil] fully comply with EPACT and will also comply with or exceed PEPCO's New Building Design Program standards.

\section{Energy Savings Performance Contracts}

FERC has noESP contraces in place at the current time.

\section{Vehicles}

FERC replaced some gasolime vehicles with altentitive foeled vehicles. These etergy-fficient vehicles are foeled by compressed tatural gas and melhanol. The utumber of executive motor vehicles was reduced by one-half.

FERC continued operating its successfiul transit subsidy program to encourage its entployees to use public transporiation. FERC also opernted an agency-wide ridesharing program that cross references zip cotes and or cities to assist employees who are seeking to join or start car or varpools.

\section{Environjmental Activities}

FERC's program is designed to protect our extemal and internal environments. The progtam works to conserve rescurces, prevent pollution, and encourage employes safety and bealth. During FY 1994, FERC operated a recycling program to collect unused office items, printer/copier toner cartidges, shuninum cans, glass, newspaper, and high grade white paper; procured and used alterative foel vehicles and recycled office products; and nomitored indoor air quality.

\section{Energy Management Contact}

Mr. Steve Goins

Federal Energy Regulatory Commission

Room 3333

825 Narb Capitol Street, NE

Washingtion, DC 20426

Futre: 202-208-0590

Fax: 202-208-1173 
' 


\section{GENERAL SERVICES ADMINISTRATION}

\section{Energy Enclency Pexformance and Inpleinentation strategies \\ In FY 1994, GSA reported a 12.2 percent decrease in energy consumed in owned and leased buildings compared to FY 1985 in Bu per gross square foot.}

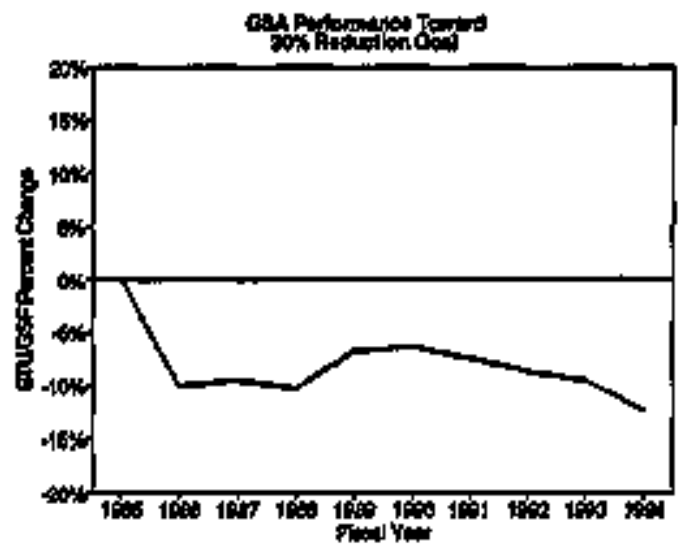

Oa February 10, 1993, GSA issued its Seven Point Energy and Water Reduction Plan to all its regicons. This plan repressents a broad-based, mutidisciplined approach to etivities to meet Federal energy goals in buildings and facilities. The sever Point include:

1. Planning and Momitoring;

2. Identification and Impienentation of Energy Conservation Technologies;

3. Improving Building Operatioktis;

4. Enployes and Tenant Conservation Awrarenes;

5. Energy Conservation in Leased Buildangs;

6. Procurement of Energy Efficient Products and Servicas; and,

7. Tràning

GSA has developed a comprebensive audit plan that incorporates 10 percent of the huventory each year for 10 years. All energy and water conservation projects tdentified as a restilt of these andits will be implemented peoding funding availability. As anoft fonding is limtod, cumtent project develojment procedures will remain in effect tor 1995 and 1996 .

To promote the Federal Ridesharing Program, the GSA regions worked with the Coumcils of Governments, state and county ridestraring units, and commuter transportation associations. The regions also conducted training for employee transportation coordintors and perticipated in ridesharing fairs.

\section{Training}

GSA bas a network of energy cocrdinators in each repion and all cooritinators are pavided yearly techoical training in state-of the-at tectnology and procedores to conserve energy. All are encouraged to become Certified Enargy Managers (CEM) through the Assoctation of Energy Engineers, a desiguation that oqualifies them as trained energy managers. GSA presently has 12 CEMs.

In FY 1994, GSA continued annual training for its notionwide/regional metrey cocodinators. At The Energy and Environmental Management Conference (TEEM '94), energy courdinators learoed about a variety of the latest technologies and approaches to energy, environmental, and water management. These inciuded areas such as reuewrable energy, Energy Star compubers, lest bed demonstrations, building energy stendards and codes, lighting tecturologies, envircounciatal products, al temalive fuel velicles, water conservation, HVAC systems, chillers, and other cumpent issues. GSA energy coordingtors in post-confexeace sessions reviewed strakegies and problem solving sessions.

\section{Funding}

In FY 1994, GSA funded S37 million for 235 energy conservation projects nationwide. Types of projects included: retrofilting existing lighting systems; installing eqerpy msnapernent and control systems; upgrading HVAC, boilers, and chiller control systems; improving byildings envelope and increasing insulation; and others. The majority of these projects focused on lighting systens because they constituto as much as 40 percent of a building's electrical consumption. All GSA energy projects are selecled based on life-cycle cost amalysis before they are fritiated. GSA expects to award \$45 milliou in energy projects in FY 1995 and $\$ \$ 8$ million is FY 1996.

\section{Energy Savings Performance Contracts}

GSA has no ESP contracts in place at the current time. However, OSA is in the process of evaluating the fersibility of having a mulotie-award, lectefinite-quantity contract with energy service companies (ESCOs) to reduce the procirement tims and rescurces nesded to $x$ repelitive ESPCs. An additional benefit of baving a single contract with multiple ESCOs will be to fulful the requirement of providing access to ESCOs to other agencies from the same GSA contract.

Overall, the ESPC concept is less attractive to GSA then that of direct investment in energy retrofit projects andior utility rebate programs because of the higher cost of fuods and greater sdministrative requirements. However, GSA informed all delegated agencies that these contracts are a vlable option to accomplishing 
energy conservation projects in buildings where funds are utavailable.

\section{Demand Side Manarement}

The GSA Seven Point Energy and Water Reduclion Plan contained a specific action requirement for the utilization of DSM programs, wtility company rebates, and other funding sources. GSA received $\$ 3$ Irillion in FY 1994 from vtility company rehate programs.

GSA has extended its DSM pilot program with utility companies in California to utilities in Colorado, Georgia Maryland, New Jersey, Virginia, Washington, and the Distritet of Columbia. The varions atilities that service these junsdictions are providing comprebensive energy surveys of GSA-0wned Federal buildings. These no-cost surveys will be used as baselines for pursuing partmership opportunicies. The energy audies represent a siguificant cost savings to GSA and they are currently being conducted on an expedited schedule using area-wide bitliny contracts.

\section{Water Conservation}

GSA has established a water program unit to coortinate a nationwide water conservalion effort. This includes evaluating existing water conservation technologies, establishment of a water consumplinen tracking system, and assuming the nole of facilitator for implementation of water projects in facilities nationwide.

A new GSA guidebootc, Water Management-A Comprehenstve Approach For Factlity Managers, has been widely distributed in the Federal sector and is

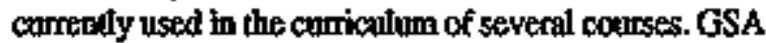
is actively involved in water efficiency partnership demonstrations with other agencies as well as intiating in-bouse projects. Additionally, an effort to track water usage nationwide (in those GSA bulldings which consume the most water) is currently underway.

Vehicles

GSA bas a wide range of energy reduction plans for motor vebicle operations. Steps are being taken to increase fuel eficiency by reducing the number of tleet vehicles and by emphasizing fuel conservation in motor vehicle operations. GSA is procuring energy-efficient velicles, reducing the number of on-band vebicles. reducing vebicle ustge, thus reducing mileage and fuel consumption, and dowasizing vebicles with smaller, fuel-effictent vehicles. Vehicle sharing/pools witl bo encouraged, and plans are underway to educate and provide enployees with fue-efficient driving techutiques that will reduce fuel usage.
GSA is actively progressing in the procurement and use of alternative fuel vejicles. The major objective is to obtain the following amoumts of AFYs for its own use: 54 in FY 1993, 67 in FY 1994, 89 in FY 1995, 183 in FY 1996, and 251 in FY 1997.

\section{Environmental Activtttes}

GSA's envirommental progratn is composed of the following elebrents: (1) resource conservation; (2) polution prevention; and (3) employe satety and bealth. Wh the conbination of these elements, the GSA program protects external and intemal environments. GSA achieves extermat environment resource conservation, and pollution prevention through waste minimization, source reduction efforts, recyeling, altemative fuel velicles, procurement of recycled producis, energy saving programs, water conservation programs, a monitoring program for underground storage tanks, the use of more efficient packaging and shipping methods, alternative worksites, flexitime, and ridesharing.

Also, GSA achieves internal environment resomrce conservation and pollution prevention through waste minimizalion, energy conservation projects, the pnocurement and use of energy efficient appliances, control of smoking, the control of hazardous waste, indoor air quatity monitoring, daytims cleaning programs, and intiatives $\omega$ control asbestos, radon, and pests.

\author{
Enercy Management Contact \\ Mr. Eric Dunham \\ National Energy Manager \\ General Services Aduioistration \\ Oftice of Property Management \\ Room 4340, PM \\ 18 th and F Serees, NW \\ Washington, DC 20405 \\ Phone: 202-208-1626 \\ Fax: 202-501-3296
}




\section{NATTONAL AERONAUTTCS AND SPACE ADMINISTRATION}

Bnergy Emfieiency Pertorm:nce and

Implementation Strategles

During FY 1994, the National Aeronaztics and Space

Administration reported a 18.7 percent reduction in buildings energy consumption in But per gross square foct conpared to FY 1985.

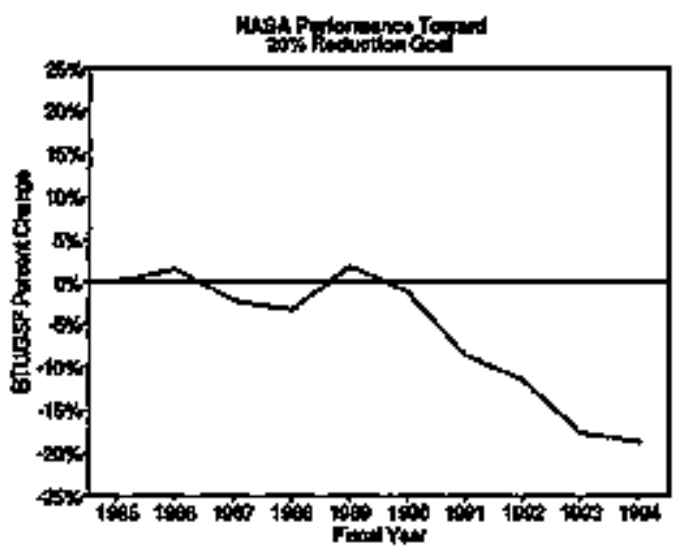

NASA manages 10 major centers in the United States, as well as other fieid installations and overseas tracking stations. NASA Management Instruciton (NMI) 8832.1, Energy Managertent through FY 2000, was approved by the Administrator on February 2, 1993. The NMI establishes NASA policy to comply with Federil energy management requirements of Executive Order 12759 and public law. It sets goals and assigns organizational responsibilities for managing and reducing energy corsumption at NASA installations. Progects and surveys are proposed by the exergy mianlager at each center, and the projects and surveys cornpete for funding akong with other ceater requinements. To compete successfilly. projects having energy conservation as their sole puppose must bave relatively sbort anoritzation periods since construction funds are very linited and have many higbpriority conmeting projects.

Energy efficiency activities conducted by NASA centers and field instatlations fall under four main categories: surveys, tnetering, operation and maimtenance procedures, and energy efficiency projects. The energy efficiency projects are as follows:

- Kennedy Space Center (KSC) completed several energy conservation projects which resulted in an anmual energy savings of 71 billion Btu and a saviags of nearly $\$ 1.1$ million. These projects included replacement of inefficient chillers, installation of variable speed chilled water purmping systems, instaltation of variable air volume systems, installation and upgrade of HVAC controls, and installation of energy eficicient hndoor and outdoor Iighting systems. Solar powered photowolkatc security perimeter lighting was installed at the Mertitt Islond Launch Amex, increasing the unmber of solar poiver applications at KSC to 24 .

- Marshail Space Flight Center initiated or conspleted many conservalion projects ouring FY 1994 incluximg refurbishment of fluxrescent lighting in office spaces, energy efficient high-bay lighting. installation of variable speed drives on air handling units and cooling towers, and the replacement of all incandescent lamps on the Center wilh compect fluorescent lemips.

- Dryden Flight Research Center installed a central energy monitoring and control system to ensane the efficient control of HVAC systems.

- Ames Research Center (ARC) instolled mil ice storage system in the Filight and Guidance Simulation Laboratory. The system shifts electrical consumpticn of mechanical refrigeration equipment to off-peak hours, and provides cost effective back-1p capacity for computer cooling. An estimated savings of $\$ 18,000$ was realized during FY 1994.

- In FY 1994, NASA fueld installations substitted seven proposals for abmost \$1.1 million in furdding from the DOE Federal Enetgy Efficiency Fmd. The proposels were priviarily for lighting netrofit projects.

NASA field insiallations have implemented various progrants to reduce the ase of vehicle fuels. Ridesharing and use of pubsic transportation is emphasized. AtNASA Headquarters, exployees are encouraged to use carpools and vinpools ox to participate in the sobsidized public transit program. Capools and vanpools are offered priority parking at NASA freld isstallations.

Training

NASA Headquarters conducted an in-house energy Iranager training copurse for 20 NASA employees in February 1994. The course covered the six competenty areas defmed in EPACT. Another 5 NASA employees and 19 contractor enployees atteteded similar FEMP. sponsored or commertial training courses, and 33 NASA energy managers and contractor employees received Certified Energy Manager (CEM) certification. 
Funding

NASA-funded facilities energy comservation projects are divided itto two categories: minor capitsl improvement projects (under 5200,000 ) that cen be achieved with field installation funds ard major ceapital improvement projects (over \$200,000) rexuiring Construction of Facilities (CoF) program funding. At the present time, energy conservalion projects inust conpete with all other construction projects for CoF funding. During FY 1994, Desily $\$ 24.7$ million wete expented by NASA on projects that tucluded significant energy efficiency and water conservation features.

\section{Energy Savings Performante Coutracts}

The Michoud Assembly factily (MAF), a Govetmment. owned, contractor-operaled (OOOO) facilhy, implemented an Fresgy Cost Retnction Program with Martin Martetta Space Systems (MMSS) in 1988. Under this program, MMSS's prime contract with NASA was motified to juclude an energy conservation incentive clause. The program retwards MMSS for exceptional performance in the maragement of energy use at MAF by providing energy savings achieved as an additional award fee. The program also inchudes provtsions for sharing savings achleved through energy conservation projects proposed by MMSS. MMSS achieved in 18 percentreduction in energy usage below the negotieted baselline in FY 1994. Energy cost savings for FY 1994 totaled $\$ 2,2$ million, of which MMSS recelved 16.4 percent as an alditional contract award fee.

\section{Demand Slde Managenent}

The Goldstone Deep Space Network complex utllizes onsite generation equipment to reduce the amount of powes purchased from Southern Californin Edison during stmmer and winter peak and mid-penk periods, soving an estinated $\$ 500,000$ per yerr by operating diesel generators during these periods. In FY 1994, Goddard Space Flight Center achieved estimated savings of $\$ 137,400$ by participating in a load contailment program with the Potomac Electric Power Company. Wallops Filpht Facility received a $\mathbf{5 3 0 , 0 0 0}$ credit for its load shedding apseement during peak summer temend periods with Delmarva Power Company. ARC perticipates in the Westem Area Power Administration Diversity Plam curtailing high electrical consumption processes dnimg high demand conditions and accounting for refunds of $\$ 3.0$ milliton in FY 1994. NASA installations received a tosal of \$365,098 in utility rehates duting FY 1994.

\section{Velifices}

In Jure 1993, KSC initiated a compressed natural gas (CNG) vehicle pilot program. The pilot CNG fleet consisted initially of three deticated CNG balf-ton pickup troxiss and a small portable refueling faciltcy to serve them. Later, two dedicated \&-passenger vans were added, as well as a bi-fuel (foled by either gasoline or natural gas) sedan. Due to the problems the menufacturer experienced with ruptured CNG fuel tanks in essly 1994, the thre piekups were retumed. However, the Center has received 1 dedicated 44-passenger bus, 7 dedicared 8-passenger vans, and 10 desticated nimivms. To date in FY 1994, there are 21 AFV's on sits To support these CNG vebicles at KSC and outyear AFV procurement, a permanent refueling facility for CNG vebicles is curtently under construction at KSC.

MAF operates a fleat of 60 NASA-owned AFVs, intcluding 23 small cargo vans, 26 picksup trucks, and 11 special purpose vehicles. Most are bì-fuel (fizeled by ejther gesoline or propane), but a few are dedicated propane-only vehicles. In FY 1924, Johnson Space Center leased a total of seven AFVs from GSA. ARC also leased a total of five AFVs from GSA.

\section{Water Conserration Projects}

KSCinitiated ot completed several water conservation projects which will save approximutely 38 million gallons of water per year. These projects included installation of ozone water treatment in cooling towers and wastewater recycling systems.

Lewis Research Center installed a cooling tower chilled water recirculation system at the Enerpy Conservation Laboratory and installed two closed loop recirculation research if cooling water systems. These systems resulted in savings of approximately $\$ 50,000$ paltons of water per day for a cost savings of $\$ 132,000$ per year.

Environmental Activities

Replacement of tetrofit of chlorofluorocarbon (CFC) chillex contimued at NASA field installations. Examples include the elimination of CFC refrigerants in 3 chilless totaling over 1,800 tons at MAF and 2 chillers tolaling over $\mathbf{4 5 0}$ tons at Stemis Space Center.

KSC has a program for the handling and disposal of discarted fluorescent lamps and obsolete ballasts. It is estimated that during FY 1994, 4,060 ballasts and over 96,000 liment feet of fluonescent lighting tubes were safely disposed.

\author{
Energy Management Contact \\ Mr. Ricinard A. Wickman \\ Envirommental Marlagentent Division (JE) \\ Nationen Aeronautics and Space Adrioistration \\ 300 E Street, SW \\ Washington, DC 20546.0001
}

Phone: 202-358-1113

Fax: 202-358-2861 


\section{NUCLEAR REGULATORY COMMISSION}

\author{
Eaergy Efrclency Performince and \\ Inplementution Strategies \\ NRC's Energy Management Implementation Plan was \\ developed is FY 1989 and is updated annally to \\ incorporate new initiatives, programs, and strategies \\ to meat the goals of Executive Order 12759. The energy \\ conservation stratiegies impleznented in FY 1994 and \\ consumption information are detailed below.
}

Ore White Fint North (OWFN) Buidding

- Use of an automated energy management system to maximize energy efticiency of HVAC eqpipment systems

- Use of occupancy sensors to control interlor lighting

- Replacement of incandescent bulibs with compact fluarescent bollbs

- Replecement of incandescent exit signs witb fluorescent exit signs

- Implementation of an employec awateness progran

- Utilization of heat exchangess to prowde free cooling

- Conducting of esergy ardits to identify potential lighting retrofit projects

- Participalion in the Potomac Electric Power Compary (PEPCO) retxale program

- Participation in the PEPCO volnatary load curtaitment program

Diring the fiss quater of FY 1994, an automated energy mamagement system was installed, The system was programmed to ensure efficient operation of heating. ventitation, and air condilitioning equipment. During the thisd quarter, incandescent signs were retrofitud with Iluorescent conversion klis.

Ton Whtte Fin Noth (TWFN) Bulling

- Use of an automated energy management system to maximize energy efficiency of HVAC equipment systemes

- Inaplemetilation of an employee atrareness program

- Conducting of entergy audits to identify potential lighting retrofit projects

- Participation in PEPCO woluntary load curtailment program

The interior butd-out of TWFN was completed in Appil [994. Phased-in occupancy began in Aptil 1994 and total building occupancy was completed in Jnjy 1994.

Paillips Buikding

- Utilization of occupancy sensors to control interior lighting
- Replacement of incandescent bulbs with conpact fluorescent bulbs

- Revised chtller and boiler ojerating plar to maximize energy savings

NRC's consolidet inm efforts wers completed in FY 1994, resulding if the relocalion of agercy gersonael from the Phillips building to the newty consoncted TWFN building. The phased move-out of agency persomitel began in April 1994 and was completed in October 1994. The FY 1993 consumption was 11,555 million Bto compared to 7,518 million Bu in FY 1994. The 35 percent reduction is attributed to the discontouation of lijhaing and HVAC as each foor was vacated. Durting the first and second quarter of FY 1994 when the brikting was totally occerpied, the eaergy conservation strategy conststed of the implententation of no-cost Initiatives. Existing time clocks were reprogrammed to reduce ron time on HVAC equjigment. Thermostats were recalithoted and an employee awareness program resulted in employees turning off fan coil utits mind office lights in unoccupied offices.

NRC is a full participant in the Merropolitan Washington Camcil of Govenuments Ride Finders Netwoik Prognm, A centralized dataluase allows NRC employees to join existing carpooks or establish carpools with ofter comnuters. NRC offers public transit subsidites to all employes; uses non-monetary incentives such as flexitime, compressed work schedules and parking assignment priontty for employees who use car pools or van pools to comrrute to work; and, provides factities for bicyclists, locluding locker rooms and showers. NRC also promotes reduction in thel consumption through transportation fairs, employee announcements, and newsletters.

\section{Training}

An on-going energy management training program has been established for NRC facility managers. NRC is an active participant in the Interagency Energy Mantagement Task Force and the Professional Energy Managers Association. As participants in the GSA 1994 Energy and Environmental Management Conference, NRC stiff members received rraining in the following disciplines: 1) Building Technologies: HVAC and Lighting: 2) Energy-Eficient Computing Technology; and 3) Water Conservation. 


\section{Eurergy Savings Performance Contracts}

No energy savings performance contracts were awarded in FY 1994 by the NRC. In FY 1995, NRC will examtine the feasiltitity of awarding performance contracts to install occupancy sensors, LED exth signes, and electronic haillasts.

\section{Deurand Sfite Mantagement}

During FY 1994, NRC participalat in the PFPCO Rebale Progran for the installation of fluorescent exit signs. No impediments or problems were encountered during 由e application, approtal, and installation process.

\section{Vehicles}

Executive Order 12759 requires all Federal agencies operating 300 or more commercially designed motor vethictes to reduce foel consumption by 10 percent. Although NRC is not subject to this order because we have less than 300 vehictes in our fleet, NRC acquires only the minimum number and size vehicle necessary omeet its needs.NRC is also in the process of reducing its number of vebicles as a result of our headquarters consalidation. This follows actions ciken in FY 1992 and FY 1993 to reduce the number and size of agency vebicles.

Although acquisition of altemative fueled vehicles is volumbary for agencies wilh less than 300 vehiches, NRC intends to participate in the program by replacing GSA assigned vehicles with alternative fueled vehtcles as they become available through GSA.

\section{Enrironmental Activities}

To ensure complianse with the Clean Air Act of 1990, NRC installed refrigerant purifier purge equipment on the chillers at $O W F N$. The equipment minimizes the level of ozone depleting chlorofluorocarbons (CFCs) which are vented to the atmosphere, Additionally, NRC has been a foll participant in GSA's recycling program since FY 1991.
Energy Maytgentent Contact Ms. Patricia Nonry

Director, Office of Administration

Nuclear Regulatory Commission

Mail Stop MNBB 6113

Washington, DC 20555

Phont: 301-415-7377

Fax: 301-492-4366 


\section{PANAMA CANAL COMMISSION}

Energy Eficiency Performonce and

Implementation Strategtes

During FY 1994, the Panama Canal Commission reported a 13.3 percent increase in buildmgs energy consumplion in Bu per gross square fook compared to FY 1985.

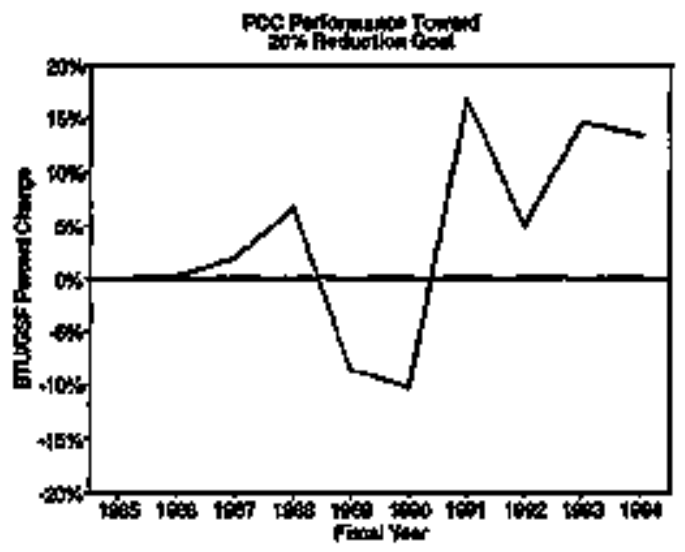

The Commissiom, given its unigue mission in the Republic of Parama, is not bound by tergeted reductions of electrical power and associated energy for butildingsfacilities, reductions of fuel use by velicles, and procuremenis of allemative-foeled veticles under Executive Otder 12759. Nevettheless, $P C C$ will continue to manage the waterway contsistent with these Federal efforts to the extent practical, until termination of the Commission and United States operation of the Pantama Canal in December 1999.

The Office of Execuliwe Planting oversees agency-wide actions io implement energy płans and actieve projected goals through its Envirommental/Energy Unit, and prepares guidance on procedures, policies and other matters govening Federad energy manggement. Tectnical and engineering coordinalors at major and specialized energy consuming areas of ite organization additionally provide assistance needed to maintain maximum operational energy efficiencies. To most effectively monitor consumption trefds, reponts on unit-level usage of electrical power, gasoline, diesel and distillate fixel ane sulbmitted monthly to lbe Environmental/Energy Unit.

The Commission's long-range Buildings Energy Plan is the basis for its ongoing buildings maintenance, monitoring and improventent prograns. FCC is responsive to tecbnical advances in the industry which enhance energy efficiencies, and state-of-art energy savings measures are incorporated where practical in bulldings and bacilities under construction or renowation. Largest and heaviest consuming buildings/facilities nomally receive first prionity foc energy related lighting and alr conditioging improvements, inrespective of Standard Buildings Services or Process/ndustrial energy usage categnry.

Recurting raaintenance inchudes mass relamping and ligbt fixume cleaning every 3 years or as lamp problems appeer. This effort was established in conndination with surveys performed to help determine specifice requtreinents for reflectors, new ballasts, lenses, and changes from incandescent or merctry vapor to fluorescent or high pressure soditom/mesal halide ligbts. Virtually all of the Commission's bnildings have been retrofitted with energy conserving lamps and light fixtores as a result of an aggressive upgrading program since 1988.

In FY 1994, two major projects were initiated to improve night ligbting sources at the locks and chanmel. One tovolves modification of 100-foot high-inast luminaires at the three sets of locks. A total of 92 masts, exch currenty fitted with six 1,000-watt metrl-balide bulbs will be rehrofitted to eight 600 -watt high -presstre sodium bulbs. The new fixtures bave instant ne-start capability and provide 12 percent more light with 15 percent less power, yielding annual savings of about $\$ 24,000$. The second telated moditication underway since FY 1994 involves 259 light fixtures along the eight-mile long Gailtind Cot, where lamps are being convented from 218-watt to 50.watt systems to improte efficiency and achieve annual savings approximating $\$ 10,000$. PCC atso installed a programmoble logic controlier will motion detectors which provides automitic partial-area office lighting. This modest exnmple of ongoing PCC projects reduces use of office lights when not needed and saves aimost $\$ 1,000$ per year in electrical power usage. During FY 1994, PCC also began installing computer monitors that consume less entergy during idlo time. All new computers purchased by the agency now meet the EPA Energy Star requirements stiptlated by Executive Order 12845, and inclode be energy-saving monitors.

Diesel foel peeded each year by dredges, driliboats, towboats, launches and ofber floating gear dominates PCC energy consumption; operation of this heavy equipment is goveraed by cyctic mainterance and improvement schedules, ship traftic, and other requirements beyond agency control. Over the years PCC engineers have significantly improved fuel conservation in its dredges, the major consumers, by replecement or corversion of old leenvy fuel oil steam-pewered plants to diesel units and by intense renovation and modemiza- 
tion. As in example the lorge ctoss hydraulic-coutetead dredge MINDI (which in FY 1994 removed over 5.6 million cubic yards of matertal at the Canal), has undergone a series of upgrading efforts since 1987 that save an average 8 gallons of fuel for every 10 cubic yaris excavaled.

The U.S. Mitiany in Panania publish a weelly newspaper and operate an English langirage TV station nccessible io Commission employes, which actively promotes conservation and canies tips and infonmation on entergy Use issues, PCC also fumishes agency-wide directives and prints articles in English and Spanish in its bimonthly official publication, THE SPILWAY, to disseminate energy-related concerns. Employee energy aprareness within the agency additonally has been fostered by the PCC Incentive Awards Suggestion Program, underway for many years.

\section{Funding}

The PCC fumctions on a self-financing basis, with recovery of all operatisg costs, including interest, depreciation, capital for plant replacement, expansion and improvententos, and payments to the Republic of Paname for public services and antuities, through tolls, and other reveoues. Revenues from tolls and all other sources are deposited with the United States Treasury into the Pansma Cangl revolving fund. Resources in this accounst are ayailable for continuous use ind serve to finance Canal openating and capital prograns, wbich are reviewed annally by Congress. PCC does not seek separale funding of its energy-related projects. PCC funds dedicated to ballasts, npgrading channel lights, final improvements to the chilled water system and other buildings/facilities energy conservation modifications totaled $\$ 607,800$ in FY 1994, and are projected to be $\$ 140,000$ in FY 1995.

\section{Energy Savings Performance Contracts}

The Commission did not enter into etrergy savings performance conatracts during de fiscal year. There is rot sufficient exonomic opportunity for this type of imitiative with PCC. given its self-fingncing basis, location overseas and teminal starys, in addition to the advanced service life of most of its buildings.

\section{Domand Side Managenent}

Electrical power for agency operations is not purchasef by the Panama Canal Commission from a servicing utility, this disconnts or other benefits from rebate progranis ane not tivailable. The Comrrission maintains is own electrical power generation systems, including two hydropower plasts that harness energy from Canal teservoirs. PCC additionally distritutes electrical power from its plants to other Canal inea consumers, primarily
U.S. military conponents which implement their own energy conservation programs in accordance wilb Federal gaidelitios and objectives.

Yehicles

FCC's gasoline-operated vehicles have been aggressively replaced by dieset nits where feasible and that program was virtually completed in FY 1992. PCC vehicles are combined under a single trotor pool for optimual administrative control and cossistent preventive maintengnce, review of fuel usagefrepair rates and evaluation for replacement. Agency policy further supports vehicle fuel savings by ensuring appropriate classes of velicles for assignments, friver training, conservative driving practices, trip consoltdation and similiz measures, Gasolineand diesel/petroleum distillate fuel consumption tor FY 1994 tokiled 246,000 and $4,741,300$ gallons respectively, at costs of $\$ 214,500$ and $\$ 2,765,300$.

Environmental Activities

Close procurement coordination with PCC operating units ensures that entwiromanentelly-fiendly products are obtained for buildings retrofits, reptacements and other energy inprovement work. The Commission considers conservation and efficiency in acquistion decistons and purchases recycled items when they meet criterta for availability, cost and needed performance standards, and where consistent with a satisfactory level of competition (PCC is required by the Panama Canal Treaty to give preference to these purchases locally).

Among PCC's currently active recycling projects is the sale of paper by kot, including recovery of computer paper for offer in Pankma at fair tharket value. Scrap incon, used oil, surplus and excess iterns also are collected for resale and recycling as part of conservalion and waste minimitration operations.

\section{Energy Management Contact}

Mr. Iuim H. Diaz

Euvironmental/Energy Control Officer

Ofice of Canal Improvements

Pantama Canal Coommission

Unit 23(X)

APO AA 34011-2300

Phone: 202-634-6441

Fax: 202-634-6439 


\section{RAILROAD RETIREMENT BOARD}

\section{Enorgy Efifictency Portormanee and Implementation Strategies \\ In FY 1994, the Railroad Retirement Board reponted as ereergy consumption decrease of 1.4 percept in Bto per gross square foot compared to FY 1986, the first year it was delegated control of its building.}

The Headoparters boikling in Chicago, Illinois, is the only builoing over which RRB has operational control. RRB operates and matntaing the bujloting under a detegation of authonty agreement with GSA.

RRB upialed tis energy conservation plan in March 1993 to troosporate the requirements of NECPA, Executive Orter 12759, and EPACT. The plan lists sone of the conditions and equipment addlions which have bindered energy reduction efforts, as well as mitiatives that RRB and OSA have taken or have planned in onder to meet the ecergy reduction goals for buildings.

The following energy eficiency actions reduced energy consumption:

- Installation of an additional bot waver heater, eliminating the need to operate a boiler

- Implementation of the followisg recommendations made in a GSA energy abdit of the building:

- reduction of operating bours for air handling units;

- reduction of the mumber of persotal computers, teminals, and printers left on-line during nonbusiness bours; and

- increase in the use of energy efficiept compact fluorescent builbs in mechanical areas.

- Coondination of daily cleaning procedures with the janicorial services contractor so that lights were turned off earlier on certain floors.

- Redaction in the number of hours that lighting in public areas of the building was operated.

- Replacement of all large electric motors with high efficiency motors, upon the recommendation of their electric utitity company.

The following projects/actions, which will firther reduce energy consnmption, are planned for fiscal year 1995:
- Installation of enexpy-saving T8 lamps and electroaic ballests in all remaining office sreas and in washrocins, and installation of additional lighting coetrots in office artos;

- installation of more energy-efficient motors on all building air handling units; and

- reduction of agency man-hmurs worked on Saturiays.

Training

This agency does avt meet the definition of an execulive department inder section 101 of Tille 5 and therefore is not sobject to the energy management training provision of this Act. However, personnel responsible for energy mantagement will rective the additiongl training which is to be provided by GSA under the Energy Policy Act of 1992 as early as posslble.

\section{Funding}

Between $\$ 10,000$ and $\$ 20,000$ of building cperating fonds are used for enesgy conservation measures annually, and $\$ 30,000$ annually is budgeted for energysaving initiatives. GSA, as the Covernment owner of the RRB building, continzes to fond projects over $\$ 50,000$. GSA has future projects planned, but not budgeted, that may reduce energy consumption.

\section{Enkrgy Savings Porformance Cantracts}

RRB has not entered tnto any ESPC contracts. The comparatively smail stze of potential contracts atailable to RRB-at a \$50,000 limit because of the delegation of authority agreemeot with GSA-is not practical for this type of procurement.

\section{Demand Side Management}

No opportunities now exist from utility conpanies for demerid-side services, incentives, or rebates, but RRB will continus to monitor its utilities for opportumities that may develop.

\section{Vehicles}

The atsency is developing information to be provided to our employes concening ridesharing awareness of fuel usage reduction measures.

\section{Envinonutental Activifles}

Now electric chisters being iastalled by GSA will use approved R-22 refrigerant. All obsolete fluorescent ballests have been and will continue to be disposed of safely and propetly. Energy manggement activities are conducted with appropriate concem for the bnilfing 
toviroument in which RRB encployes work Aqpopriste anounts of ontside air are provided to ensure proper envirormental coaditions.
Enerry Management Contact

Mr. Oharlie Davis, Jr.

Facility Montager

U.S. Railroad Retrement Board

Room 1230

844 N. Rush Street

Chicago, IL 60611

Phone: 312.751 .4566

Fax: $312-751.4923$ 


\section{Energy Effictency Pertormathes and Implementation Strategies \\ Doring FY 1994, the Tenmessee Valley Authority reported a 0.5 percent increase in energy consumption in Bto per gross squire foot compared to FY 1985.}

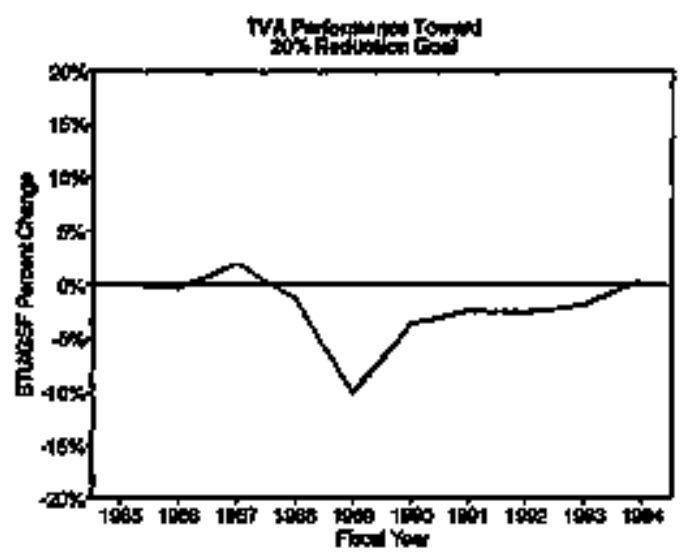

TVA doveloped its Agency Exergy Plan and submitted it to DOE on March 1, 1994. TVA is currendly updating this Ptan and is developing a TVA Energy Policy to be submitued to the TVA Boand for approval in FY 1999.

To insure TVA's proper compltance with Federal Regulations and obligations under the Green Lights Program, IVA formed an interagency Entergy Conservation Committee (ECC). This committee is comprised of representatives from each TVA orgenization responsible for ebergy consumption in buildings, facillites, operations, and equipenent iaside the agency. The ECC reduces the chance of duplication of effort and the possibility of missing the chance to implement important energy or environnental appications.

During FY 1994, TVA identified 163 operation, ritaintenance, and 33 water objectiwes. The following operations and majntenance programs have been implenented to dale by TVA.

- Use of the most efficient tighting systems availahie

- Reduce lighting levels where light outpot exceeds requirements for the space

- Install light switches or motion sensurs in areas not cumently controlled

- Instail photocell control on outdoor lighting."

- Night setback thermostals or EMCS instalbations.

- Use outside air for cooling whes possible.

- Report building energy consumption data on a per building basis for major energy use buildings for accurate tracking of entrgy usage trends.
- Review maintenance procedures and make repairs to reduce energy consumption.

- At \$kull Island and Mallard Creek Campgrounds the well water systens were abandoned and water is now obmined from the koal utility. This eliminated the kocal pump and biweekly inspection trips to the well houses.

- At Noris, Tennesse facility, the HVAC mit serving the computet room was replaced with a more efficient unit.

- A regular steam fine insulation móisternarce program has been inpiemented.

- Electric diven boiler feed water pumps are now being used for the mam boiler. The steam driven pumps are used obly for backup.

- The controls on the package boiler aro now under a regular matntenance program to maintain maximum performance.

- An energy monitor has been appointod and steam traps ars now on a regular inspection and maindenance program. The estimated cost reduction for FY 1995 is $\$ 92,000$.

- Buildings with only partial occupancy are caly beated in the occupied areas.

- Any unused steam or electric lines were elianinated to reduce standhy losses.

- Instalked two smiall natural gas fired boilers to replace one large natural gass boiler for a first month savings of $\$ 20,000$.

During FY 1994, an enployee energy awareness campaign was implemented by the Facilities Services energy reduction team. Initiatives of the team inchaded displaying monthly energy use posters in large office buiklings, periodic notes to remind enployees to turn off unnecessary equipment, and "Energy Fair 1993" held in Knoxville, Chatanooga, and Muscle Shoals to enhance coergy education. TVA is also working to combine TVA's employe enexgy awareness puogtam with its solid waste minimization program.

TVA epcourages employees to ride share and, in some cases, will find employees traveling to the same destination to avoid the use of multiple vehicles. They also propmole the use of mass tramsit systems when availabie and teasible.

\section{Training}

TVA has appointed bujlaing energy moniturs for cach of its major tacilities and provides ongoing energy mantgemeut training for these indivituals. TVA also provides updates on current Federal requirements and 
regulations for employees and tbeir managers upon reguest.

\section{Funding}

TVA is ctrrently establishidg a funifing procedure for energy conservation projects. Past energy efficiency projects have been funded throngh builfing tentovation and modernization efforts. TVA considers for impiementerion ail costefirective opportunities, which are evalualed using the-cycte cost metbodology and implepiented as tunds become available. 'TVA's current procurement policy includes a statement that energy management and eficiency will be onsildered aloug with envinomen. tol impacts when new or replacement esergy-consuning equipmeat is purchased.

Duting FY 1994, TVA spent \$349,164 for surveys of 46 boildings covering almost 2,1 million square feet. One houdred eleven cost-effective eurergy conservation opportunities were identifled. Estimated cost to implement these was $\$ 1.6$ million with a potential yearly savings of $\$ 407,000$.

\section{Energy Savings Performance Contracts}

TVA considers the use of energy savings performance contracts when cost-effective to TVA and its customers. TVA did not enter into any energy savings performance contracts during FY 1994.

\section{Demind Stie Manigement}

TVA is an electrite utillty and, therefore, extablish demand side activities when cost-effective and in the best interest of its customers.

\section{Vehides}

During FY 1994, TVA expanded its AFV fleet with the addlion of $20 \mathrm{M} 85$ sedans and 5 electrtc plckup trucks. This brought TVA's AFV heet to a total of 31, consisting of 13 M85 Dodge Spirtts, 10 M85 Ford Tauriu, 2 CNG Dodge vans, I electritc van, and 5 electric pickups. The 10 Chevrolet Corsicas on order were canceled due tomanpifacturing problems. Oxe importmit fact concloded from the first full year of AFV fleet mpctvement was the difficuley of procuring a teliable and cost compettive supply of methanol. This difically, glong with the growing support for elecride vehicles (EVs) as fle type most compratible with TVA's long-erm plans as on all electric vitilty, have lead to greater interest and support for focousing on EVs. TVA has established a puhlic EV Irfommation Ceoter in conjunction' with an expomied local transit anthority facility highlighting electric buses. In addition, TVA is developing an edicational proerarn for secondary schools and partnesing with bocal electric distrilbutors to assist vocational and technical schools on EV technology.
During FY 95, plans are to add an additional 6 electric $A F V_{8}$ to finalize an electric transportation policy, and to complete the AFV field iest.

TVA-owned vehicte inventory at the end of FY 1994, excludring construxction aquipmsnt and trailers, was as follows: 1,456 sethis, 206 station wagons, 2,040 light trucks, and 151 motor scooters for a tobal of 3,853.

\section{Enviranmental Activities}

TVA became the fist Federal agency to join tie EPA Green Lights program. TVA has set as ore of its three major corporate gosis to become an environmentil leader. TVA has embarked on a solbd waste minimization program, sustainable architectural program and a byproducts wilb recycle content program. Listed below are some of the efiorts in these areas.

A solid waste reduction program was phased into TVA's corporate factlities during FY 1994. The program goal is to reduce by 80 percent the amount of waste going to landfills through elimination, reuse, or recycling. Higblights of the program to date include the use of hand dryers in place of paper towels; reusable beverage mugs in place of styrofoam and paper cups; and recycling of whtte and mixed paper, cardboard, newspaper, plastic, glass and steel and aluminum cants.

Sustalnable architecture is designing and construting buiktings that have a minimnm negative impact on the environment. TVA is developing ways to utilize the approaches of sustaitrable architecture. Repusable wall partitions are being evaluated to seplace drywall. Low toxic materials are being introduced. Recycling old materiats and purchasing new materials from recyched components is being explored. The innuediate goal of the sustalnabie architecture project is to impact the renovation work taking place in TVA's Kroxville corporate office builating. The long-term goal is to incorporate sustainable architecture in all TVA renovation and aew construction wark.

TVA is one of the first utilities to announce a plan to reduce its greenhouse emissions, which come prirriarily from coal-fired plants.

Energy Management Contact

Mr. Steven L. Brothezs, Jr.

Power Uülizatimn Engineer

Tentnessee Valley Anthority, MR 2J-C

1101 Market Street.

Chattenooga, TN 37402-2801

Phone: 615-751-7369

Fax: 615-751-6767 


\section{UNITED STATES POSTAL SERVICE}

\author{
Energy Efliclency Performance and \\ Impłernentation Strategies \\ In FY 1994, energy use in U.S.Postal Service facilities \\ decreased by 2.6 percent in Biu per gross square foot \\ compared to FY 1985.
}

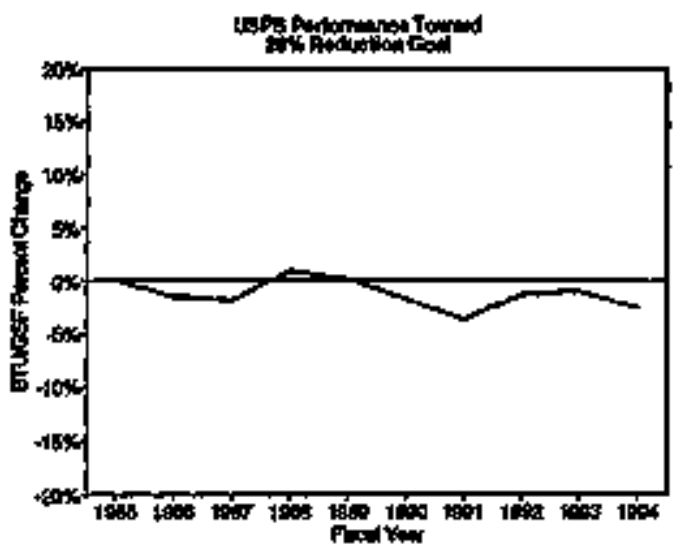

The U.S. Postal Service's energy management plans encompass all aspects of energy conservation and facorporate financial, procurement and operating strategies, and include a strong entphasis on densand side mandigentemt, altentalive fuels, and the exvirombent. The plans esablish anergy performince goals by region. As a result of restructuring, the energy plans wil establish performance goals consistent with the new Area structure.

The Postal Service has established Area Energy Coordinators consistent with the Area Mandgement stnucture. Additionally, each Area Energy Cocrdinator has designated field energy coordinators and facility egergy coordinators. The Postal Service compiled a composite listing of all individuals responsible for energy conservation and assessed their credeatials relative to the trainod energy manager citeria set forth in EPACT.

The Postal Service is unique among agencies in ils use of the Federal Acquisition Regulations. This has allowed the Postal Service the ilexibility to adopt the best parchasing principles of both the private and poblic sector. As such, it allows flexibility to adapt purchasing policy to accommodate the changing environment in which purchasing is dowo by considering tho cuergy efticiency of goods and products and eaviouménal waste mantagement. Under the Postal Service's "best value ${ }^{x}$ buying philosopty, price and price-related factors are not the key elenentus in a buying decision. Other ibctors, such as energy contsumption, effichency and other life-cycle costing factors carry as much or more treight in detemining contract awards.
In FY 1994, USPS began an initialive to educate purchasing persontrel regarding responsibilities under EPACT as well as other energy conservation isswes, such as sonroes of supply for energy-efficient products. This was accomplished torough a serties of triefings to all lovels of management concerning both energy and envirommentol issues. In atdition, a special 2-day training session was held in August 1994 with the field extery coortinaters as well as purthasing representaives. A quarterly uewspaper for purthising persontnel cowers specific energy and environurental issues. Training materials have been developeri emphasizing the role and responsibility of contracting oficers in complying with energy and envirumental regnatarons. Devetopment of energy-specific gujdance for inclusion in the Postal Service Procurement Manual is ongoing.

FY 1994 is the fonth year of the Postal Service ridesharing program in the south coast area of Southern Califomia. Employees ans offered a number of cirect incentives incleding a transit subsidy, a guaranteed ride home and preferentint parking. The program also includes a newslester, educacional activities, flexible work bours ano recognition awards. The Postal Service will begin trip reduction programs in additional norattainment areas as defued by the Clean Air Act

\section{Training}

During September 1994, 20 energy coordinators attended an in-deph training course in energy surveys. This training was developed and presented by the Association of Energy Engineers.

\section{Funding}

Energy projects within the Postal Service are prioritized using criterta such as operational need, safely issues, and toconontic bentefits. Economic bentefits ane neastred by net present value and return on investment to the Postal Service. Projects are identified dusing surveys conducted by field maintensmce persomntel. Funding to accomplish the projects may come from local budgets or Headquarters.

Durhig FY 1994, projects totaling almost $\$ 3.0$ miltion were approved for Headquarter's fundong with ower \$1.1 million aciually expended. The difference is due to project implementation time frames. Several of the projects involved relhates from the local utility company. The USPS energy conservation program budget for $F Y$ 1995 is projected at $\$ 10$ million. These funds will be used for energy surveys, studies, and retrofit projects. 
In FY 1994, USPS finalized the development of "special" contractual instruments that will simplify the process of contracting for the identirication and fielding of energy retrofit projects, eitier througb the energy savings performance contract concept or demand side management.

Energy Savings Performance Contracts The Postal Service has shared energy savings contracts currendy in place at four locations: San Diego General Mail Facility, Oklaboma City General Mail Facility, New Orleans General Mail Facility, and Southem Maryland Genteral Mail Factlity/Bulk Mail Center. Project stmmaries are as follows;

$\begin{array}{llr}\begin{array}{l}\text { Project } \\ \text { Location }\end{array} & \begin{array}{l}\text { Antual } \\ \text { Savings }\end{array} & \text { USPS } \\ & \text { Share } \\ \text { San Diego } & \$ 138,968 & 61.0 \% \\ \text { Ordaboma City } & \$ 78,101 & \mathbf{8 . 1 \%} \\ \text { New Onleans } & \$ 100,194 & 11.2 \% \\ \text { So. Maryland } & \$ \$ 5,109 & 12.0 \%\end{array}$

Based apon lessons leamed from these projects and curent market trends, Heakganters Maintenanoe Polictes and Programs in a joint effort wth Headquarters Purchasing Policies developed generic contract and techmical documents for national use or energy savings perfommance contract projects.

\section{Demand Stde Management}

Demand side mantigenent servites are one of the certral strategies of the Postal Service energy management program. During 1994, the Postal Service particjpated in several vility demsond reduction and rebate programs. The perinership efforts with Baltimore Ges and Electric (BG\&E) is an exemple. Working with BG\&E, the Postal Service offered factlities for irvestigation of BG\&E's "Energy Saver Switch" program. This program is designed to reduce consminption in smaller facilities by cycling the air conditioning system's conpressor. The net result was installation of the "Energy Saver Switch" at 60 Postal facilities. The Pogtal Service received a bonus amount for the irstallation of the switches and credits appear on the monthly uitity bills for each of the facilities. The Postail Service is continuing to work wilh BG\&E for inclusion of the Ballimore processing and distribution center in its DSM program.

The Postal Service continues to work closely with Wisconsin Power installing efficient lighting fixtures in facilities throughout the Milwaukpe area Rebates contimue to be received from Wisconsin Power as projects are completed.
The Postel Service recently received an award for successful energy-saving efforts from Portland Genecal Electric and a rebate of \$51,740 resulting from enorgy savings in excess of $\$ 180,000$. These savings were realized by installing efficient lighting fixtures in 10 localions around the Oregon area which reduced lighting costs by almost 48 pereent.

Of particular note was the continual development of our partnerșip arrangentent, along with other Federal agencies, with Pacific Ges and Electric. Using a standard. contract format, PG\&E will surwey taclitios and idontify energy retrofit projects that will provide the greatest retum on investratent These projests will not be limited in scope to energy retrofits, byt will cross the complete spectrutn of etergy conservation. Possible funding mechanisns include billing via the otility bill.

\section{Vebicles \\ The Postil Service continues to operaite the largest compressed naharal gas (CNG) fleet in the country. The atternalive fuel vehicle program is continuing as an energy conservation and environmental strategy. The Postal Service Alternative Foel Vehicle (AFV) program is a Headquarters-funded program. During FY 1994, $\$ 4.0$ million was spent on AFV converstons, with $\$ 8.0$ million twogeted for this propram for FY 1995. The large variance is dure to contract award time frames. State and locel funding assisted in accomplishing CNG conversions.}

In 1994, the Postal Service converted over 1,000 of its delivery vehicles to operate on CNG. Now, there are 1,663 velicles operating on CNG. It received eight methanol wehicles in 1994 and has ordered five ethanol vehicies.

\section{Energy Management Contact}

Mr. Paul Fennewald

Maintenance Policies and Programs

U.S. Postal Service

475 L'Enfant Piazs, $\$$ W

Washington, DC 20260-7311

Phone: 202-268-2589

Fax: 202-268-2705 


\section{APPENDIX A LIST OF AUTHORTTIES :}

ENERGY POLICY ACT (Public Law 102-486), October 1992

FEDERAL ENERGY MANAGEMENT DMPROVEMENT ACT OF 1988 (Public Law 100615), January 1988

NATIONAL ENERGY CONSERVATION POLICY ACT (Public LAw 95-619), November 1978

ENERGY POLICY AND CONSERVATION ACT (Public Law 94-163), December 1975 SECTION 381 - FEDERAL ENERGY CONSERYATION PROGRAMS

OFPP POLICY LETTER NO. 76-1, August 6, 1976

FEDERAL PROCUREMENT POLICY CONCERNING ENERGY POLICY AND CONSERVATION

EXECUTIVE ORDER 12759, April 17, 1991

FEDERAL ENERGY MANAGEMENT

DEPARTMENT OF ENERGY ORGANIZATION ACT (Public Law 95-91), August 1977 TITLE III - TRANSFERS OF FUNCTIONS

SUPPLEMENT NO. 1 TO OFPP POLICY LETTER 76-1, July 2, 1980

PERTINENT FEDERAL REGULATIONS

FEDERAL ACQUISTTION REGULATIONS (23.2) (SUPERSEDES FEDERAL PROCUREMENT REGULATIONS [1-1.339-1])

DEFENSE ACQUISITION REGULATIONS (7.103(h)2) - SUPPLEMENTAL TO 7.10I FAR

FEDERAL ENERGY MANAGEMENT AND PLANNING PROGRAMS

(TITLE 10 CFR Chapter 11, Part 436)

FEDERAL PROPERTY MANAGEMENT REGULATION

(TITLE 4 CFR Chapter 101, Subchapter R, Part 101-25) 



\section{APPENDIX B \\ DATA COLLECTION}

Buildings and Facilities

Excluded Buildings Process Operations

The Federal agencies that own or control brildings are required to report the energy consumption in these buildings to FEMP 45 days after the end of each fiscal year. The General Services Administration (GSA) reports the energy of buildings it owns and operates, tncluding usage by other Federal agency occupants. For buildings which have been delegated by GSA to other agencies, the individual agencies are responsible for reporting the energy consumption and square footage figures.

The data shown in this report do not include leased space in buildings where the energy costs are a part of the rent, and the Federal agency involved has no control over the buildings' energy management.

The Federal agencies submit their annual reports expressed in the following onits: megawatt hours of electricity; thousands of gallons of fuel oil; thousands of cubic feet of natural gas; thousands of gallons of liquefied petroleum gas (LPG) and propane; short tons of coal; billions of Btu of purchased steam; and billions of Btu of "other." DOE reviews this data for accuracy and confers with the sobmitting agency to clarify any apparent anomalies. The data are then entered into a computer database management program.

The tables shown in this Annual Report are expressed in billions of But derived from the following conversion factors:

$\begin{array}{lll}\text { Electricity } & - & 3,412 \mathrm{Btu} / \mathrm{kilowatt} \text { hour } \\ \text { Fuel Oil } & - & 138,700 \mathrm{Btu} / \mathrm{gallon} \\ \text { Natural Gas } & - & 1,031 \mathrm{Btw} / \mathrm{cubic} \text { foot } \\ \text { LPC/Propane } & - & 95,500 \mathrm{Btu} / \mathrm{gallon} \\ \text { Coal } & - & 24,580,000 \mathrm{Btw} / \text { short ton } \\ \text { Purchased Steam } & - & 1,000 \mathrm{Btw} / \text { pound }\end{array}$

In addition, the Federal agencies annually report to FEMP the gross square footage of their buildings and the cost of their buildings' energy.

This report excludes those agencies that have been unable to provide complete fiscal year consumption data prior to the publication date. All agency omissions, as well as any anomalies in the data, are indicated by footnotes on the tables or in the text of the report. 
Vehicles and Equipment

Federal agencies are required to report the energy consumption of their vehicles and equipment to FEMP within 45 days after the end of each fiscal year.

The fuels used in vehicles and equipment are automotive gasoline, diesel and petroleum distillate fuels, aviation gasoline, jet fuel, Navy special, liquefied petroleum gasspropane, and "other." All the fizels in this category with the exception of "other" are reported in thousands of gallons. "Other" is reported in billions of Bto.

The conversion factors for these fuels are:

$$
\begin{aligned}
& \text { Automotive Gasoline - } \quad 125,000 \mathrm{Btu} / g a l l o n \\
& \text { Diesel-Distillate - 138,700 Btu/gallon } \\
& \text { Aviation Gasoline - 125,000 Btw/gallon } \\
& \text { Jet Fuel - 130,000 Bav/gallon } \\
& \text { Navy Special } \quad-\quad 138,700 \text { Btu'gallon } \\
& \text { LPG/Propane - 95,500 Bto/galion }
\end{aligned}
$$

Missing data and anomalies are addressed in the same fashion as those described previously in this appendix. 


\section{APPENDIX C \\ FEDERAL ENERGY EXPENDITURES AND COST AVOMANCE,}

FY 1985 THROUGH FY 1993

C.1 
TABLE C

FEDERAL ENERGY EXPENDITURES AND COST AVOIDANCE, FY 1985 THROUGH FY 1994 (NOMINAL DOLLARS)

\begin{tabular}{|c|c|c|c|c|c|}
\hline YEAR & $\begin{array}{l}\text { AYAURL ENSBGY USE } \\
\text { (EBTO) }\end{array}$ & $\begin{array}{l}\text { MNOWL EAEROY COST } \\
\text { IS YILLIONT }\end{array}$ & 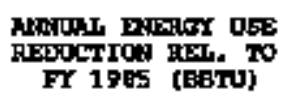 & 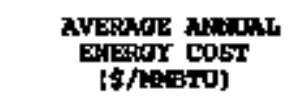 & 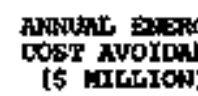 \\
\hline \multicolumn{6}{|c|}{ Butlainge and Facilitien } \\
\hline $\begin{array}{l}1995 \\
1996 \\
1997 \\
1999 \\
1999 \\
1990 \\
1991 \\
1992 \\
1999 \\
1994\end{array}$ & 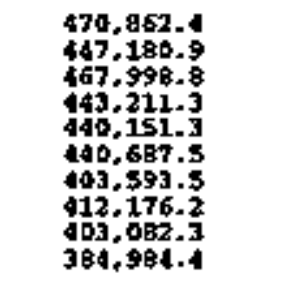 & 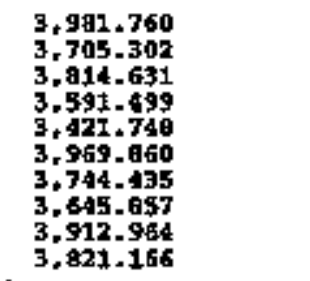 & $\begin{array}{r}0.0 \\
23.681 .5 \\
2,663.6 \\
27,651.1 \\
30,711.1 \\
30.174 .9 \\
67,266.9 \\
50,696.2 \\
67.790 .1 \\
85,879.0\end{array}$ & $\begin{array}{l}\theta .456 \\
0.206 \\
0.151 \\
0.103 \\
7.774 \\
9.000 \\
9.270 \\
0.045 \\
9.700 \\
9.926\end{array}$ & $\begin{array}{r}0.000 \\
196.223 \\
23.341 \\
224.056 \\
238.745 \\
271.825 \\
624.103 \\
515.102 \\
657.982 \\
852.382\end{array}$ \\
\hline BEF Total & & & & & 3.607 .774 \\
\hline \multicolumn{6}{|c|}{ Vehicles \& Equipmost } \\
\hline $\begin{array}{l}1995 \\
1996 \\
1997 \\
1998 \\
1999 \\
1990 \\
1991 \\
1992 \\
1993 \\
1954\end{array}$ & 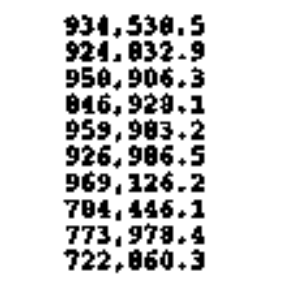 & 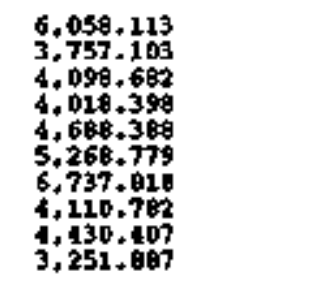 & $\begin{array}{r}0.0 \\
9,705.6 \\
-24,367+9 \\
97,610+3 \\
-25,444,7 \\
7,552+0 \\
-34,597+7 \\
150,092,3 \\
160,560+3 \\
211,679+2\end{array}$ & $\begin{array}{l}6.493 \\
4.062 \\
4.274 \\
1.745 \\
1.994 \\
5.694 \\
6.952 \\
5.240 \\
5.724 \\
1.499\end{array}$ & $\begin{array}{r}0.000 \\
39.029 \\
-104.156 \\
115.693 \\
-124.267 \\
42.924 \\
-210.470 \\
706.539 \\
919.079 \\
952.264\end{array}$ \\
\hline Vis Thtal & & & & & $2,603,023$ \\
\hline \multicolumn{6}{|c|}{ Eneror Intoneive ope } \\
\hline $\begin{array}{l}1985 \\
1986 \\
1987 \\
1980 \\
1989 \\
1990 \\
1991 \\
1992 \\
1993 \\
1998\end{array}$ & $\begin{array}{l}40,090.6 \\
39.124 .6 \\
38,669.1 \\
69.664 .3 \\
69.593 .2 \\
65.903 .7 \\
89.676 .5 \\
98.768 .6 \\
76.797 .7 \\
93,091.0\end{array}$ & $\begin{array}{l}396.130 \\
395.304 \\
391.758 \\
667.409 \\
564.446 \\
659.860 \\
795.607 \\
900.199 \\
604.300 \\
975.299\end{array}$ & $\begin{array}{r}0.0 \\
1,974 .-0 \\
1,429.5 \\
-29,565.7 \\
-23.494 .6 \\
-25.205 .1 \\
-13,577.9 \\
-58,670.0 \\
-30,699.1 \\
-52,992.4\end{array}$ & $\begin{array}{r}9.925 \\
10.105 \\
10.131 \\
9.580 \\
6.676 \\
10.105 \\
9.506 \\
9.114 \\
9.536 \\
10.477\end{array}$ & $\begin{array}{r}0.000 \\
19.954 \\
14.492 \\
-203.250 \\
-200.535 \\
-254.692 \\
-61 . .344 \\
-534.731 \\
-262.093 \\
-555.193\end{array}$ \\
\hline EI 0ps Total & & & & & $-2,478.348$ \\
\hline Total AU Enercy & & & & & $3,816.446$ \\
\hline
\end{tabular}

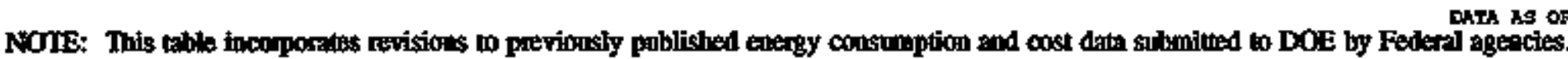

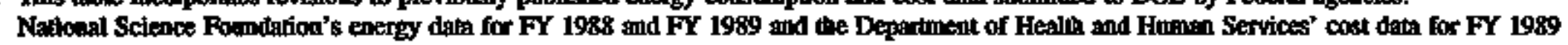
ane estimated.

Source: Foderal Ageocy Alnual Eurgy Management Data Reports 
FIGURE C

FEDERAL GOVERNMENT

AVERAGE ANNUAL ENERGY UNIT COSTS,

FY 1985 THROUGH FY 1994 (NOMINAL DOLLARS)

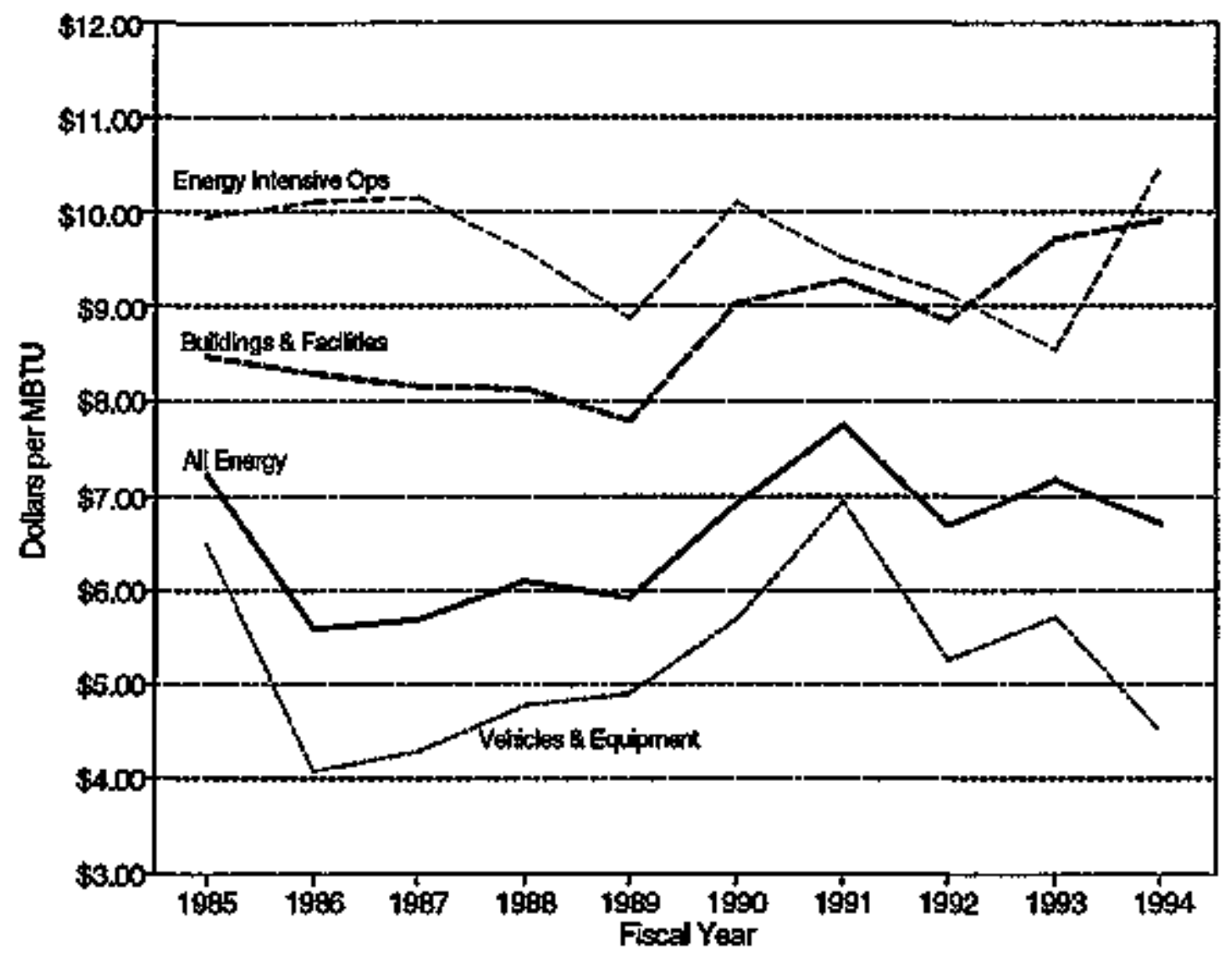

Source: Federal Agency Annual Energy Managemint Dath Reports 


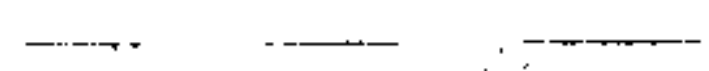
$-$ 


\title{
APPENDLX D \\ FEOQRAL PERFORMANCE UTILIZING \\ "SOURCE"' CONVERSION FACTORS
}

\begin{abstract}
Appendix D and the accompanying tables are included to show performance using the source conversion factor of $11,600 \mathrm{Btw}$ per kilowatt hour of electricity instead of the site conversion factor of 3,412 that is used throughout this report. These tables also use the source conversion factor of 1,390 Btu per pound of steam instead of the site conversion factor of 1,000 Btu per pound. The source conversion factors represent the average number of Btu required at the point of generation (source energy) rather than the actual amount of Btu delivered to the site. The tables in this Appendix are provided to illustrate the Federal Government's total impact on actual energy resources.
\end{abstract}

Using the conversion factor of 3,412 Btu per kilowate hour of electicity provides comparability with the measurement of energy usage in private sector buildings. The factor of 3,412 Btw per kilowatt hour of electricity is the average number of Bte actvally received at the point of use (site energy) from that original $11,600 \mathrm{Bta}$ input. The difference between site and source units reflects efficiency losses during power generation, transmission, and distribution to firial users.

The accompanying tables show agency performance using the conversion factor of $11,600 \mathrm{Btu}$ per kilowatt hour of electricity. This is the same consumption and performance reported in Tables 1, 4, and 7, but expresses electricity and steam use in terms of source Btu instead of site Btp. 
TABLE D-1

TOTAL ENERGY USE BY FEDERAL AGENCIES - SOURCE CONVERSION

(In Billions of British Thermal Units, Millions of Barrels of Oil Equivalent [MBOE], and Petajoules [Joule $\mathrm{x} 10^{15}$ )

\begin{tabular}{|c|c|c|c|c|c|c|c|c|c|c|c|c|}
\hline $\begin{array}{l}\text { Cryingan } \\
\text { AgENCY }\end{array}$ & $\underset{1965}{F Y}$ & $\underset{19 Y}{F Y}$ & $\underset{1987}{F Y}$ & $\frac{78}{2988}$ & $\underset{1969}{F V}$ & 1990 & $\underset{1991}{p \gamma}$ & 1992 & ${ }_{1993}^{F y}$ & $\begin{array}{c}F Y \\
1994\end{array}$ & $\begin{array}{l}\text { CHAHKGE } \\
\text { O5-9d }\end{array}$ & - CHAMKSE \\
\hline 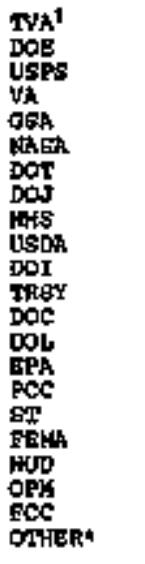 & $\begin{array}{r}1.899 .5 \\
97,530.9 \\
50,969.1 \\
12.926 .5 \\
12.963 .0 \\
23.365 .7 \\
38.560 .2 \\
11,026.5 \\
12,970.7 \\
12,152.0 \\
11.40 .0 \\
3,506.0 \\
1.038 .0 \\
7,920.0 \\
1.341 .8 \\
1.189 .4 \\
204.0 \\
190.5 \\
340.6 \\
158.1 \\
42.0 \\
528.1\end{array}$ & $\begin{array}{r}1,966.6 \\
92,002.4 \\
51,457.3 \\
42,135+6 \\
34,062.9 \\
24,633+6 \\
28,525+2 \\
11,591.6 \\
10,654+3 \\
10,761.5 \\
9,955.3 \\
3,479+0 \\
3,631.2 \\
3,969+3 \\
2,131.5 \\
1,300 \times 1 \\
740+5 \\
295.6 \\
350+1 \\
174.5 \\
41.6 \\
830.7\end{array}$ & 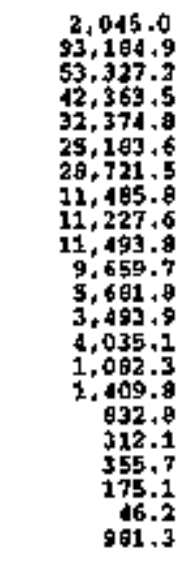 & 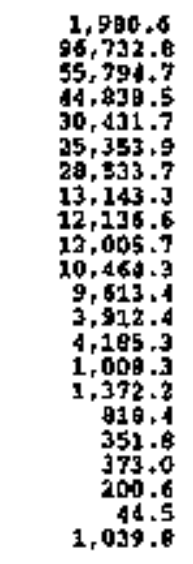 & 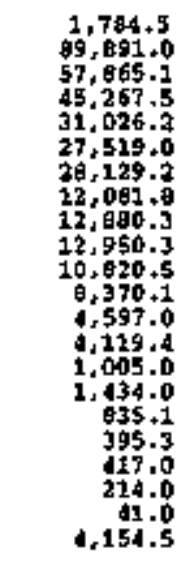 & 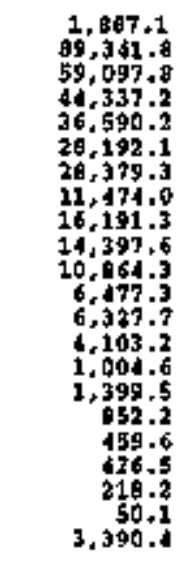 & 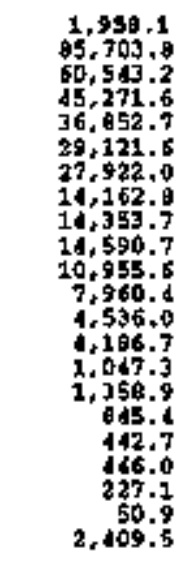 & 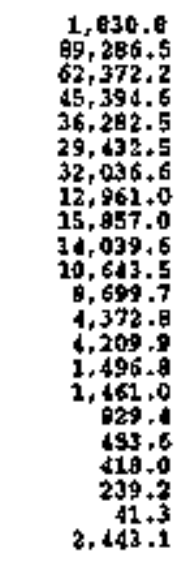 & 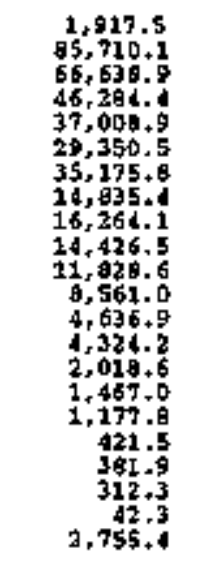 & 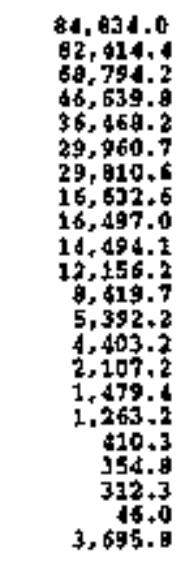 & $\begin{array}{r}6.366 .1 \\
-15.5 \\
35.40 \\
8.7 \\
-15.1 \\
28.2 \\
4.4 \\
50.9 \\
27.1 \\
19.3 \\
6.3 \\
133.5 \\
33.5 \\
17.3 \\
57.0 \\
24.4 \\
79.4 \\
115.4 \\
4.2 \\
65.8 \\
9.7 \\
409.4\end{array}$ & $\begin{array}{r}4,32 . .2 \\
-3.8 \\
3.2 \\
0.8 \\
-1.5 \\
2.1 \\
-15.3 \\
12.1 \\
1.4 \\
0.5 \\
3.8 \\
-1.7 \\
16.3 \\
1.8 \\
4.4 \\
0.8 \\
3.2 \\
-2.7 \\
-3.1 \\
0.0 \\
8.9 \\
34.2\end{array}$ \\
\hline $\begin{array}{l}\text { CTILILAN } \\
\text { TOTHL }\end{array}$ & $\begin{array}{l}\text { MEENCIES } \\
351,976.6\end{array}$ & $334,826+4$ & $339,473.6$ & $554,335.3$ & $355,797.9$ & 365.461 .9 & $364,946.7$ & $374 x+901.6$ & $395,539,4$ & $466,586.0$ & 32.6 & 21.0 \\
\hline DOD & $1,494,704+2$ & $1,460,467+5$ & $1,537,276,3$ & $1,424,872.0$ & $2,564.051 .2$ & $1,536,176,1$ & $1,55 \mathrm{~d}, 075.0$ & $1,380,726.4$ & $1.330,916.1$ & $1,253,516.9$ & -16.1 & -5.18 \\
\hline 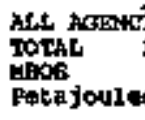 & $\begin{array}{r}\overline{I E S} \\
1,046,590.9 \\
319.0 \\
6 \quad 1,948,2\end{array}$ & $\begin{array}{r}1,795,314,0 \\
309,2 \\
1,896+0\end{array}$ & $\begin{array}{r}1,876,709.8 \\
3282.2 \\
1,979.9\end{array}$ & $\begin{array}{r}1.779 .200 .1 \\
305.4 \\
1,877.0\end{array}$ & $\begin{array}{r}1,919.049 .1 \\
329.6 \\
2,025.4\end{array}$ & $\begin{array}{r}1,901,638.0 \\
326,5 \\
2,006.2\end{array}$ & $\begin{array}{r}1.919,021.7 \\
329.4 \\
2.024 .5\end{array}$ & $\begin{array}{r}1,763,528.0 \\
302+9 \\
1,060.5\end{array}$ & $\begin{array}{r}2,316.455 .6 \\
291.7 \\
1,816.6\end{array}$ & $\begin{array}{r}1.720 .103 .0 \\
.295 .3 \\
1,814.5\end{array}$ & $-6+9$ & 0.2 \\
\hline 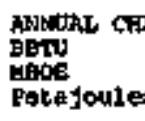 & FANGE FROM 198: & $\begin{array}{r}-51,366.9 \\
-8.8 \\
-54.2\end{array}$ & $\begin{array}{r}30,069.0 \\
5.2 \\
31.7\end{array}$ & $\begin{array}{r}-67.472+6 \\
-11.6 \\
-72.2\end{array}$ & $\begin{array}{r}73,160.2 \\
12.6 \\
73,2\end{array}$ & $\begin{array}{r}56.957 .1 \\
9.4 \\
58.0\end{array}$ & $\begin{array}{r}72,360.8 \\
12.4 \\
76.3\end{array}$ & $\begin{array}{r}-83,252.9 \\
-14+3 \\
-87+7\end{array}$ & $\begin{array}{r}-130,225.3 \\
-22.9 \\
-137.4\end{array}$ & $\begin{array}{r}-126.573 .9 \\
-21.7 \\
-133.3\end{array}$ & & \\
\hline 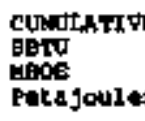 & 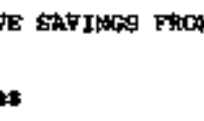 & $\begin{array}{r}1965 \text {. } \\
51,366.9 \\
8.8 \\
54.2\end{array}$ & $\begin{array}{r}21,297,9 \\
3.7 \\
22,5\end{array}$ & $\begin{array}{r}98,770+7 \\
15.2 \\
93.6\end{array}$ & $\begin{array}{r}15,602.5 \\
2.7 \\
16.5\end{array}$ & $\begin{array}{r}-39.354 .6 \\
-6.6 \\
-61.5\end{array}$ & $\begin{array}{r}-111,695.4 \\
-19.2 \\
-117.8\end{array}$ & $\begin{array}{r}-28,5 d 2.5 \\
-4+9 \\
-30.1\end{array}$ & $\begin{array}{r}101.692 .7 \\
17+5 \\
107.3\end{array}$ & $\begin{array}{r}226.260 .6 \\
79 .+2 \\
340.8\end{array}$ & & \\
\hline
\end{tabular}

*Other includes the Commodity Futures Trading Commission, Equal Employment Opportunity Comiritssion, Federal Trade Commission, National Archives and Records Adoninistration, Nuclear Regulatory Comnission, Railroad Retirement Board, The U.S. Information Agency, and the Federal Energy Regulatory Commilission for FY85 to FY89.

'TVA's large imcrease in energy constemption for FY 1994 is the result of first-time reponting of electricity consumed at power planls for station service use.

Note: FY 1994 contains estimated data for the tollowing agencies: Departments of the Treasury, State, Environmental Protection Agency, Federal Trate Commission, and Ofice of Personel Management. Sum of components may not equal total doe to independent rounding.

Source: Federal Agency Anqual Energy Management Data Reponts 
TABLE D-2

FEDERAL BUILDINGS AND FACMITIES USE PER GROSS SQUARE FOOT - SOURCE CONVERSION

FOR FY 1985 AND FY 1994

(WHEN ELECTRICITY EQUALS 11,600 BTU/KWH)

\begin{tabular}{|c|c|c|c|c|c|c|c|}
\hline & $\operatorname{Gs} \times 10^{\circ}$ & $\begin{array}{r}\text { FISCAL YEAA } 1995 \\
\text { BTW } \times 10^{9}\end{array}$ & BID/GSE & $\operatorname{GsE} \times 10^{\circ}$ & FISCAL YEaR 1994 & BNo/GEF & $\begin{array}{c}\text { CHange } \\
1905-1994\end{array}$ \\
\hline 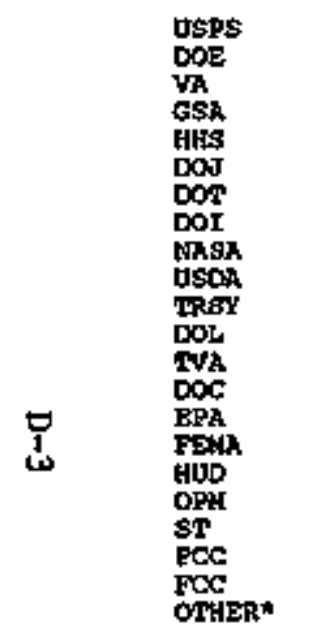 & 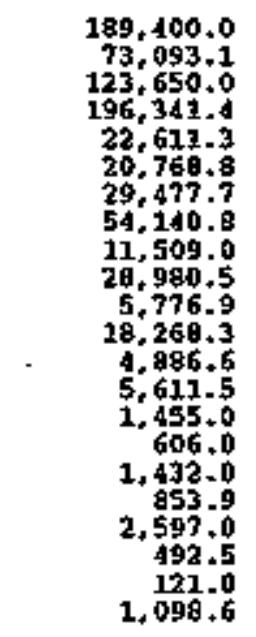 & 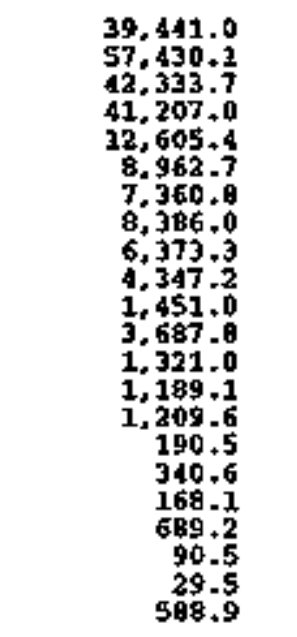 & $\begin{array}{l}208,242 \\
765,711 \\
342,367 \\
309,874 \\
557,494 \\
431,545 \\
249 ; 706 \\
154,993 \\
553,771 \\
150,004 \\
251,178 \\
201,871 \\
270,333 \\
211,905 \\
631,313 \\
314 ; 426 \\
237,962 \\
196,622 \\
265,377 \\
189,054 \\
244,132 \\
536,037\end{array}$ & 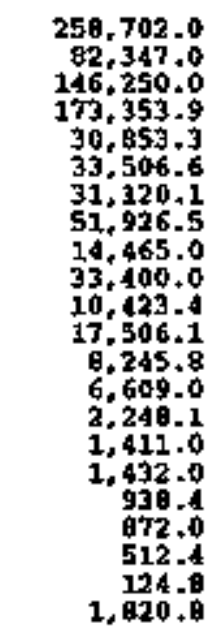 & 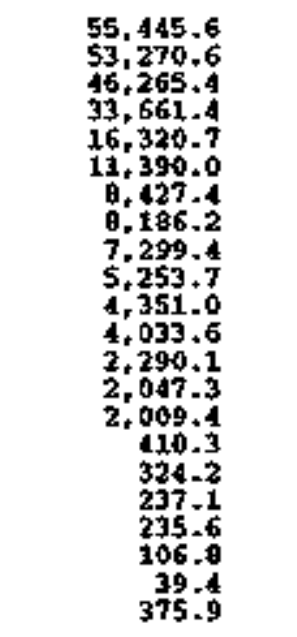 & 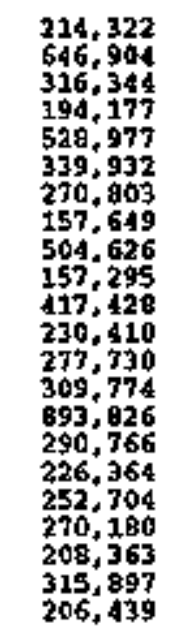 & $\begin{array}{r}2.9 \\
-17.7 \\
-7.5 \\
-7.5 \\
-5.3 \\
-21.2 \\
6.4 \\
1.8 \\
-8.9 \\
4.9 \\
65.2 \\
11.2 \\
3.7 \\
46.2 \\
7.5 \\
-7.5 \\
-4.0 \\
28.4 \\
1.4 \\
13.3 \\
29.4 \\
-61.5\end{array}$ \\
\hline $\begin{array}{l}\text { CrvinIant } \\
\text { Torat }\end{array}$ & $\begin{array}{l}\text { DEENCLES } \\
393,171,9\end{array}$ & 239.403 .1 & 301,930 & $908,069+2$ & $261,981,0$ & 288,504 & -4.4 \\
\hline DOD & $2,578,984.0$ & $581,170.2$ & 225.349 & $2,197,852.0$ & $502,215.0$ & 228,503 & 1.4 \\
\hline TOTAC & $3,372,155.9$ & a20,533.4 & 243,338 & $3,105,920.2$ & 764.196 .0 & 246,045 & 1.1 \\
\hline & & & & & Dhe NS 0 & $03 / 20 / 95$ & \\
\hline
\end{tabular}

* Obler inclodes the Commodity Futures Trading Commission, Equal Employment Opportunity Commission, Feiteral Trade Commission, National Avchives ated Records Administration, Nuclear Regulatory Commission, Railroad Retirement Baant, and the U.S. Information Agenty.

Note: FY 1994 contsios estimated data for the following agencies: Department of Treasury, Federal Trado Commission, and Office of Personnel Memagement. Sum of components may not egual botal due to independent rownding.

Sounce: Federal Agency Annral Energy Managentent Data Reports 
TABLE D-3

FEDERAL ENERGY USE IN BUILDINGS AND FACILITIES - SOURCE CONVERSION

(In Billions of British Thernal Units, Millions of Barrels of Oil Equivalent [MBOE], and Petajoules [Joule $\times 10^{15}$ )

\begin{tabular}{|c|c|c|c|c|c|c|c|c|c|c|c|c|}
\hline $\begin{array}{l}\text { CTVILIAN } \\
\text { Hexter }\end{array}$ & $\begin{array}{c}\text { PY } \\
1998\end{array}$ & $\begin{array}{c}\mathrm{FY} \\
1986\end{array}$ & $\begin{array}{c}\mathrm{eY} \\
1997\end{array}$ & $\begin{array}{c}\text { FY } \\
\text { 1998 }\end{array}$ & $\begin{array}{c}\stackrel{F y}{9} \\
1989\end{array}$ & $\begin{array}{c}\text { Fr } \\
1990\end{array}$ & 2991 & $\begin{array}{c}\text { Ht } \\
1932\end{array}$ & $\begin{array}{c}\text { FF } \\
1993\end{array}$ & $\begin{array}{c}\text { Fy } \\
1994\end{array}$ & $\begin{array}{l}\text { C CFANGE } \\
\text { ES-9S }\end{array}$ & $+\underset{93-94}{\text { change }}$ \\
\hline 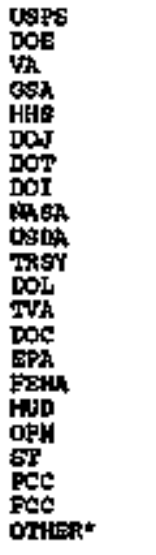 & 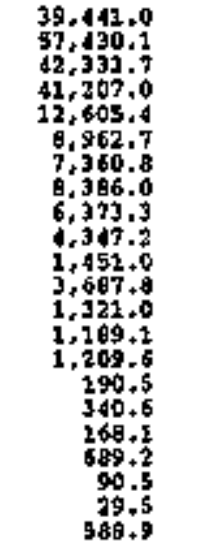 & $\begin{array}{r}39.669 .0 \\
55,158.4 \\
11,538.9 \\
33,948.9 \\
10,322.4 \\
9,539.8 \\
9,694.0 \\
6,849.9 \\
6,710.6 \\
4,210.0 \\
2,423,9 \\
3,751.7 \\
1,526.2 \\
2,571.4 \\
2,096.5 \\
295.6 \\
359.2 \\
174.6 \\
724.5 \\
90.9 \\
31.9 \\
796.9\end{array}$ & 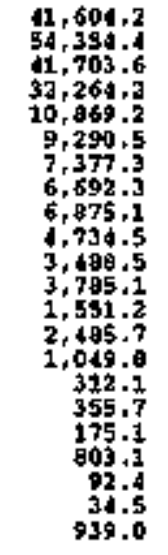 & 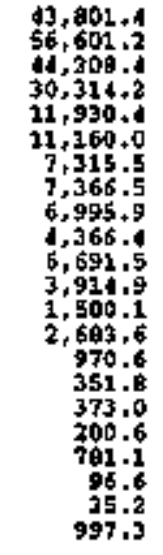 & 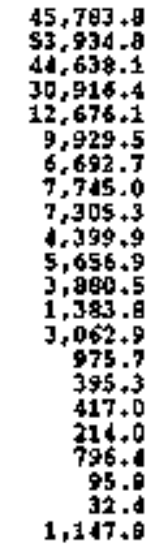 & 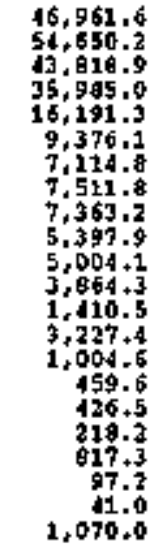 & 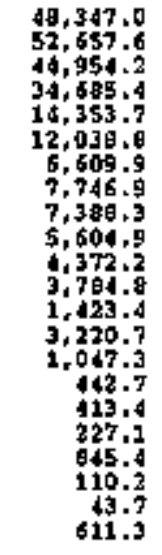 & 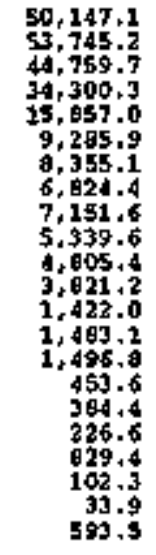 & 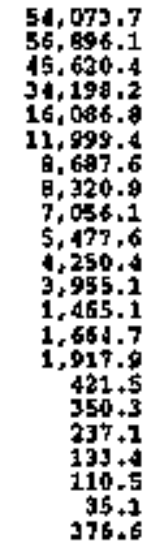 & 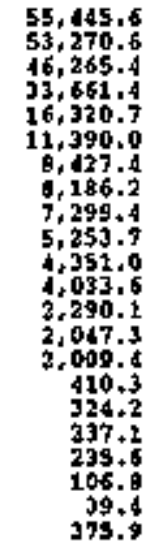 & $\begin{array}{r}40.6 \\
-7.2 \\
9.3 \\
-19.3 \\
29.5 \\
27.1 \\
14.5 \\
-2.4 \\
11.5 \\
70.9 \\
299.9 \\
93.4 \\
73.4 \\
72.2 \\
66.1 \\
115.3 \\
-4.8 \\
41.2 \\
-65.8 \\
17.9 \\
33.5 \\
-36.2\end{array}$ & $\begin{array}{r}2.5 \\
-6.4 \\
1.4 \\
-1.6 \\
1.5 \\
-5.1 \\
-3.0 \\
-1.4 \\
3.4 \\
-4.1 \\
2.4 \\
2.0 \\
56.3 \\
23.0 \\
4.9 \\
-2.7 \\
-7.5 \\
0.0 \\
76.5 \\
-3.4 \\
22.4 \\
-0.2\end{array}$ \\
\hline $\begin{array}{l}\text { CVILIN } \\
\text { TOMAL }\end{array}$ & $\begin{array}{l}230,403,1 \\
30,45 S\end{array}$ & $230,669.2$ & $230,037.7$ & $212,656.2$ & $242,079,8$ & $252,011, d$ & $250,929.0$ & $251,428.1$ & $263,334.5$ & $261,962.0$ & 9.4 & -0.5 \\
\hline$\infty$ & $501,170+2$ & $\$ \$ 2, \$ 98, \theta$ & $595,765.7$ & $546,227.6$ & $576,994+6$ & $580,104,5$ & $523,370.8$ & $524,164,8$ & $523,295.3$ & $502,215.0$ & -13.6 & -4.0 \\
\hline 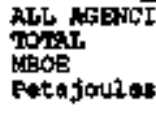 & $\begin{array}{r}020.573 .4 \\
140.9 \\
665.7\end{array}$ & $\begin{array}{r}783+267+8 \\
134.5 \\
826.3\end{array}$ & $\begin{array}{r}825,603.9 \\
141.9 \\
073.0\end{array}$ & $\begin{array}{r}789,739.7 \\
135.4 \\
633.1\end{array}$ & $\begin{array}{r}619,074.5 \\
140.6 \\
964,1\end{array}$ & $\begin{array}{r}832,196.0 \\
142.9 \\
97+.9\end{array}$ & $\begin{array}{r}774.299 .8 \\
732.9 \\
816.9\end{array}$ & $\begin{array}{r}775,583.8 \\
133.1 \\
818+2\end{array}$ & $\begin{array}{r}786,529.8 \\
135.0 \\
929.9\end{array}$ & $\begin{array}{r}364,+196.0 \\
131.2 \\
905.2\end{array}$ & $-6,9$ & -2.9 \\
\hline 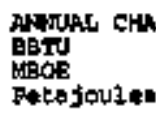 & MUE PRON 1985 & $\begin{array}{r}-37,305.5 \\
-6.4 \\
-39.4\end{array}$ & $\begin{array}{r}6,030.0 \\
1.0 \\
6.4\end{array}$ & $\begin{array}{r}-31,799.7 \\
-5.5 \\
-33.5\end{array}$ & $\begin{array}{r}-1,490.9 \\
-0.3 \\
-1.6\end{array}$ & $\begin{array}{r}11,622.6 \\
2.0 \\
12.3\end{array}$ & $\begin{array}{r}-46.273 .6 \\
-7.9 \\
-49.8\end{array}$ & $\begin{array}{r}-44,990.6 \\
-7.7 \\
-47.5\end{array}$ & $\begin{array}{r}-33,943.6 \\
-5.6 \\
-35.6\end{array}$ & $\begin{array}{r}-56,377 \cdot 1 \\
-9 \cdot 7 \\
-59+5\end{array}$ & & \\
\hline 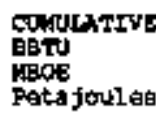 & SAYINAS FPON & $\begin{array}{r}1985,305.5 \\
6.4 \\
39+4\end{array}$ & $\begin{array}{r}31,275,6 \\
5 . \$ \\
33,0\end{array}$ & $\begin{array}{r}63,065.2 \\
10.8 \\
66.5\end{array}$ & $\begin{array}{r}64,564.1 \\
11.1 \\
50.1\end{array}$ & $\begin{array}{r}52,941.5 \\
9.1 \\
55+9\end{array}$ & $\begin{array}{r}99,213.1 \\
17.0 \\
104.7\end{array}$ & $\begin{array}{r}204,205.6 \\
24.6 \\
152.2\end{array}$ & $\begin{array}{r}178 x+29.3 \\
30.6 \\
187.9\end{array}$ & $\begin{array}{r}334.326 .7 \\
40.3 \\
347.4\end{array}$ & & \\
\hline
\end{tabular}

"Other includes the Commiodity Futures Trading Cormutission, Equal Employment Opportunity Commission, Federal Trade Commission, National Archives and Records Administration, Nuclear Regulatory Commission, Railrosd Retirement Board, the U.S. Infomation Agency, and the Federal Energy Regulatory Commission for FY85 to FY89.

Note: FY 1994 contains estimated data for the followiog agencies: Department of Treasury, Federal Trade Commission, and Office of Persomulel Managenent. Sum of compontents may not equal total due to independent rounding.

Source: Federal Agency Aunual Energy Management Data Reports 


\section{APPENDIX E \\ BUILDINGS EXFMPTED FROM NECPA'S \\ PERTORMANCE GOAL IN FY 1994}

Section 543(a)(2) of NECPA states, "An agency may exclude from the requirements of paragraph (1) any building, and the associated energy consamption and gross square footage, in which energy intensive activities are carried out. Each agency sball identify and list in each report made onder section 548 (a) the buiflings designated by it for such exclesion." These buildings are not included in the calculations for determining performance toward the buildings Btw/GSF reduction goals. Instead, they are included under the category of excluded buildings/process energy. The energy consumed in these buildings is included on tables and figures which show total consumption (buildings and facilities, vehicles and equipment, and excluded buildings(process).

\section{Departiment of Commerce}

\section{National Institute of Standards and Technology}

Gaithershing. Maryland Slites

101 Administration

102 Gave House

202 Eng. Mech.

205 Fire Research

206 Concr. Mirts.

220 Metrology

221 Physics Lab

222 Chemistry

223 M(r)s. Test.

224 Polymers

225 Techoology

226 Building Reserarch

230 Fluid Mecb.

231 Industrial

233 Sound

235 Reactor

CNRF

236 Hazards

237 Non-magnetic

238 Non-magnetic

245 Radiation

301 Supply and Pin.

302 SCWPG

Cooling TWR

303 Service

304 Instr. Shops

305 Switchgear

306 Elec. Sub.

307 Chemical Waste

308 Bowman Kouse

309 Grounds

310 Hanards Strg.
311 Grounds Strg.

411 TRF

412 Temp. Ofc

413 Temp. Ofc

415-418 Temp. Ofc

419 Temp. Childcare

Boulder, Colorato Sites

1 Radio

I A Radio Building

IB Radto Building

iC Radio Building

ID Radio Butlding

2 Cryogenics

2A Cryogenics - Annex A

3 Liquifier

3A Liquifier - Anmex A

4 Canco

5 Camco Annex

8 Mesa Test Site

9 Gas Meter

11 Ionospheric Observatory

14 Field Sirength

21 Maistenance Garage

22 Warehouse

24 Plasma Physics

24A Plasng Physics - Annex A

25 Maintenamce Shops

26 Day Care Facility

27 High Frequency 
National Oceanic and Amospheric Adminisfration

AKWO11 E.T. Shop

AKW129 Elec. Storg. Bldg. \& Fac.

AKW130 Marine Warebouse

ARMOO4-WFO

CAWOT2 SW Fisheries Cntr

CAW107 WSO

CA4486 WSFO

COC004 WSFO

COMO17 Optics Bldg \& Fac.

COM018 Lab. Bldg

COM019 Lab. Bldg

COM053 La3. Bldg

CTE005 Chem Storg. Bldg. \& Fac.

FLEO78 Port of Miami

FLMO24 WSO

HIW015 WSO

LAM048 OfC. Bldg

MAE032 Morris Island Obsery

MEEDOS NWS Forecast Ofc

MOC036 WSFO

MOCO37 NEXRAD Bldg
MSM011 WFO

MTWO05 Radar Bldg

MTW0119 Balloon Infitin. Bldg

NCC001 Dive Locker \& Fac.

NEC008 Balloon Infito. Blidg. \& Fac.

NMM021 WFO

NVW016 Ballown Inffer. Bidg

NY545I 30 Rockefeller Plaza

ORW012. Fue Station/wso

ORW065 WSO

PAE013 Storage Bkdg. \& Fac.

TNMO06 WFO

TXM1029 WSO

UTW004 Balloon Inflm. Bldg

VAE014 Antenna Deck \& Fac.

WAW052 Behavior Lab. \& Fac.

WVEOHZ NWS BIds

Bureat of Census

Charloste Computer Center 


\section{Department of Defense}

Process energy use at Department of Defense (DoD) facilities, or "buildings" noder- the definition of PL 100-615, is separately identified from the building and facilicies energy use reported under the goal of section 543. Some DoD facilities have both building and facility use, and process energy vse. DoD actively manages "process energy" facilities in such a manner as to achieve a ten percent cnergy efficiapcy improwement goal by FY 1995. The following lists those facilities which report process energy and are exempt from NECPA's perfomnance goal.

Anmy

Cold Region R\&E Lab, Hantover, NH

Dist. Engr, Humtington, WV

Dist. Engr, Jacksonville, FL

Dist. Engr, Mobilo, AL

Dist. Engr, Wimingtor, NC

Dist. Engt. Charteston, SC

Dist. Engr., Little Rock, AR

Dist, Engr, Galveston, TX

Dist. Engr., Rock Island, IL

Dist. Engr., Detroit, MI

Dist. Engc., Kansas City, MO

Dist. Engr, Omaha, NE

Dist. Engr., Los Angeles, CA

Dist. Engr., San Francisco, CA

Stratford Engine Plant, CT

21st SUFCOM, Germany

Dist. Engr., New York, NY

Dist. Engr., Ballimore, MD

Lima ARMODCTR, OH

Tobyharipa ARDEP, PA

Scrinton AAP, PA

Radford AAP, VA

Redstone Arsenal, Huntsville, AL

$\checkmark$ Corps, Frankfunt, Germany

Holsion AAP, Kingsport, IN

Pinc Blufif Arsenal, AR

Dist. Engr., New Orkeans, LA

Louisiana AAP, Sireveport, LA

Sunflower AAP, Laurence, KS

Detroit Arsenal, Warrech, MI

Lake City AAP, Independence, MO

Fort Leonard Wood, Whynesville, MO

Dist, Engr., Sacramento, CA

Mississippi AAP, Picaytane, MS

\section{Air Forse}

Tyndall AFB, Panamia City, FL

Rhein Main AB, Germany

Litule Rock AFB, AR

Pope AFB, Fayetictille, NC

Doter AFB, DE
Offutt AFB, Omaha, NE

Beale AFB, Marystille, CA

Hollomar AFB, Alamogurdo, NM

Seymour Johnson AFB, Goldsboro, NC

MacDill AFB, Tampa, FL

Canon AFB, Clovis, NM

Bergstrom AFB, Aasth, TX

Davis Montion AFB, Tucson, AZ

Mountioin Home AFB, ID

Spartewabn AFS, Alaska

Shemya AFB, Alaska

Navy

NSY, Portsmouth, NH

NSY, Ptiladelphis, PA

NAC, Indianapolis, IN

NSY, Portsmonth, VA

NSC, Norfolk, VA

NSY, Charleston, SC

NSY, Mare Island, CA

NSC, Oakland, CA

NSC, San Diego, CA

NSY, Puget Sound, WA

NSY, Pearl Harbor, Hawait

NAVSUBASE, Pearl Harbor, Hawail

NSC, Puget Sound, WA

NSC, Pearl Harbor, Hawaii

NSC, Charleston, SC

NSY, Long Beach, CA

NAPC, Trenton, NI

NSRF Gunm, Marianas Islards

NSSPO, Magna, UT

NARF, Alameda, CA

NARF, Jacksoiville, FL

NARF, Norfolk, VA

NARF, Sem Diego, CA

NARF, Pensecola, FL

NARF, Chersy Point, NC

NSPASURSTA, Cbula Vista, CA

NSPASURSTA, Maricopa, AZ

NSPASCRSTA, Truth or Consequences, NM

NSPASURSTA, Archer City, TX

NSPASURSTA, Lewisville, AR

NSPASURSTA, Hillandale, MS 
NSPASURSTA, Wenumpka, AL NSPASURSTA, Hawkinswille, GA NSPASURSTA, Savannah, GA

NWIRP, Toledo, OH

NIROP, Rochester, NY

Grumman Aerospace, Bethpage, NY

NIROP, Pittsfield, MA

NIROP, Minneapolis, MN

NIROP, Sunnyvale, CA
Altegany Baflisstics Lab, Pinta, WV

NIRP, St Paul, MN

NWIRP, Bloomfield, CT

NIROP, Poisiona, CA

NWRIP, Bedford, MA

Grumman Aircraft Eng., Calvertom, NY

DLA

$\overline{D C S C}$, Columbus, $\mathrm{OH}$

\section{Department of Energy}

Los Alamos National Laboratory

117 Lab Tratlers

36 Permanent Lab Buildings

29 Transportable Lab Buildings

4 Pan Am Trailexs

Zia Caft Shop

Pre-Engineered Shed

Welding Shop

Lab Office Bldg

Equipment Test Lab

Lab Meson Facility

Operations Bldg

Service Corridior

Accelerator Tec Bldg

LANSCE/WNR Bidg

Proton Storage Ring

High Res Beam Facility

Gereral Pupose Lab

WNR Lah Support BIdg

Warehouse

Proton Storage Staging Ring

FMIT BIds

Accelerator Tec Bldg

Modulator Bldg

Developmeat \& Testing

Computer Maintentance

Data Analysis Center

Accelerator Maintenince Blig

Sub-Stopkroom/Whse

JCl Craft Shop

Prolon Storage Ring Eqp

Experimental Area

Neutron Scaltering Exper

NPB Technical Support

Shop \& Storage Bldg

Office Blds

Warehoxiss

Office Bldg

Med Resolution Spect

Neutron Exper Service
ATSU Facility

ML, Neutron Scattering Fac

Kansas Ciry Plant

Industrial Wastewater Pretreament Facility

Mound Facility, Mamisburg, Ohto

Cos Buikding

HH Building

$M$ Bitlding

Butlding 28

Building 36

Building 60

Buildang 85

Building 87

Building 105

Pantex Plont

16-4/Paint and Sand Blast.

16-10Vehicle Wash

Rocky Flats

025 Broontield Worehouse

122 Medical Addition

124 Water Treatment Plant

125 Standards Calibration Lab

129 Water Treatment

223 Gaseous Nitrogen Piant

333 Paint Shop

371 PU Recovery Facility

374 PU Recovery

439 Modification Center Support

440 Modificasion Center

444 General Fab and Tool Corl

445 Carbon Storage

447 Manufacturing

460 Non-Nuclear Mfg Building 
566 Protective Clothing Decontarnination

559 PU Analytical Lab

569 Crate Counter

707 PU Fab and Assy

71 PU Recovery

774 Process Waste Trealment

776 Manufacturing Butling

777 Assembly

779 PU Development Building

790 Radiation Calibration Laboratory

865 Process Development R\&D

881 Manufacuring Support

883 Manufacburing

886 Nuclear Safety Facility

889 Hillside Tratmout Plant

910 Reverse Osmosis

Precision_Forgs

002 Administration Offices

003 Machine Shop and Met Lab

004 Grinding Shop

005 Press Stop

006 Hammer Shop

Sandia National Laboratorles, Abuquergue

(Site No. OLI2)

858Microelectronics Devetopment Lab

878/Process Devel Lab

963/Strategic Defense Facility II

Sandla Nattonal Laboratories, Livermore (Site OIJ3)

Compoter Center

Argonat National Lab-Eass (Sise 030z)

145 AMPEL Figeility

146 Fuel Control OFC

360 IPNS CNTL

361 Injector Building

363 Shops and Assembly

364 Center Buildes

365 Rinig Building

366 and 366A HEP Storage

367 IPNS Storage

368 Power Building

369 EPB-I

370 OTEC, HIF

371 Heavy Ion Fusion

372 IEP Office

373 HEP Assembly

374A. Storage

$375,375 \mathrm{~A}, 375 \mathrm{D}$ IPNS and Storage
376 IPNS and RMPS Storage

377 Cooling Tower

377A, 377B, 377C Technical Equipment and

Storage

378 Supply

379 Supply

380 SSD-HP Office

381 CPFF

382 Cryogenic Lab

384 Storage

385 Survey Laboratory

389 RF Power Supply

390 Cryogenic Controt Room and Lab

391 Rapid Cycle Synchurotrox

399 IPNS Control

549A and 549B Electric Substations

Argonse Nattonal Lab-West (Site 0303)

Building 704

Butlding 753

Building 754

Buildimg 757

Building 757A

Building 758

Building 764A

Building 765

Building 766

Building 767

Buidding 768

Building 786

Btiłloting 798

Bluilding 799

Butlding 720

Builoing 776

Building 707

Brookhaven National Lab

Mefical Research Reactor

Pumphouse, Cooling Tower

Valvehouse

Equipment House

Instriment House, Docts (DEC)

Canal House (DEC)

Synchrotron Light Source

High Flux Beam Reactor

Cold Neutron Facility

Fanhouse

Tandem Van Do Graffs

Dymamitron/Van De Gragf

Cyclotron

Accelerator Development

Cryogenic Test Pacitlty

Pett VI 
Heavy Ion Power Supply

Heavy Ion Power Supply B

Hervy Ion Beam Tuntel

Expermeatal Halls, AGS

Mechamical Equipment

AGS Tumnel

A.C. House Northeast

A.C. House North

A.C. House Northwest

A.C. House Southwest

A.C. Honse Southeast

Proton House Complex

Besm Components

7 Works Buillings

E-10 Power Supply

2 Scientific Assembly Buildings

N. Experimental Tunnel

MG Power Supply

RF Power Supply

200 Mev Linac

Irradiation Facility (CLIFF)

Isotope Producer (BLIP)

F-10 Equipment

Cryogenic Power Tramsmission

Electical Testing

Rextiation Effects Tumel

Magnet Power Sopply

Production Holding

Blip Pump Honse

5 R\&D Facilities

Nentrino Facility Building

Beam Analysis

Expetimental Counting House

Compressor Buildjug

Collider Center

Princeton Plasma Physics Laboratory

D-Site (TFIR)

LOB Basement

CS Buildiag (Basement)

RF Building (1, 2, 3 Floor, Center Room)

System Test Building

MG Building (Basement, 1 Floor, Mezz)

PLT 1 Power Building

Cooling Tower

Idnko Operations

INEL (0603)

Idaho Falls (0602)

Laumdry

Equipment Building

Laboratory

Boiker Hoose, Oil-Fired
New Waste Calcining Facility

Coal-Fired Steam Generator Facility (CFSGF)

CFSGF Coal Unloading Building

Liquid Effluent Treatment and Dispasal Facility

Manufacturing/Assembly and Hot Cell

SMC Manufacturing and Waste Treatment

ATR Resctor Building

ATR Secondary Pmip House

ATR Deep Well Pump House

TRA Diesel Generator Boilding

ATR Waste Heat Recovery System Pung House

TRA Secothary Pump Hoose

WVDP (0607)

Frocess Ptant

Cement Solidification System

Maintenance

T \& Bullding

Low Level Waste Treatment. Facility

Lag Storage

Warehouse

New Warehouse

Antex

Trailer Ciry

Component Test Stand

STS Process

STS Suppont

Miscellaneous Trailers

Ptant Office

Utility Room

Laundry

Wasts Tank Farm

Bulk Storage Warehouse

New York Disposal Area

Rad Treament System Drum Cell

Conterence Room

Schoolhouse

Z1-Z23 Trallexs

OBl Office Bullding

Expanded Envinonmencal Laboratory

7-24 to 7-26 Trailers

AA-1 to AA-7 Trallers

AA-8 to AA-14 Tratlers

AA-15 to AA= 21 Trajlers

Grand Junction (0608)

North Sample PlanvOffice Core Sample Storage

Data Processing/Oftice Connpater Center

Oak Ridge Office

Chemistry Laborntory

3 Trailers 
Oak Ridge National Lab (Site IO04)

High-Flux Isolope Reactor

Holifield Heavy Ion Research Facillty

Electron Linear Accelerator

Oak Ridge Research Reactor

Isotope Tecb Latb

Radioscopic Produstion Lab

Off-gas Facility/Waste Monilor Control Facility

Y-12 Plant (Site 1006)

Building 9999-3

Paducah Gaseous Diffusian Plant (Sise 1008)

Purge and Product Buidding

Product Withdrawal Building

Surge and Waste Building

4 Process Buildings

Feed Vaporization Facility

Feed Vaporization Building

Power Buildting

Metals Butlding

Slag Building

Toll Transter and Sampling

Stabilization Building

Feed Plant

Greensalt Plant

Portsmonth Gaseous Diffistion Plant (Site 1009)

3 Process Buildings

Switch House

2 Test and Repair Buildings

2 Oit Hovses

4 Valtre Houses

Switch House

Gas Reclaim Cart Garage

3 Recirculation Water Pump Houses

Pump House

Sewage Treatment Facility

Cony Shoug and Cleaning Building

Air Conditioning Equipment Building

Line House

Water De-iouization Facility

Neutralization Bujldieg

Effluent Monitoring Faxility

Decontimintion Building

Incinerator

Heat Boost Pump Building

Maintentance and Stores Butlding

Ravio Base Station

Paint and Storage Building

Hazzrdous Waste Storage
Raw Water Punphouse

Water Treatment Plant

Lagoon Pusmping Station

Filter Butilding

Recarbonization Inst Builiding

Ltquid Emuent Control Facility

Fire Training Builting

Sonth Portal and Shelter

North Portal and Shelter

SNM Monitoring Portal

SNM Portal N.W.

S. Enviroamiental Sample Building

2 N. Enviroumental Sample Bujkungs

Envirotimentos Storage Bailding

Steam Plant Sboo Building

Diesel Generator Builting

S. PH Control Facility

N. Holding Pond Storage Building

Explosion Test Facility

4 Non UEA Warehouses

Material Receiving and Inspection

Electronic Maintenance Facility

Pike Avenuse Portal

2 Personnel Monitor Buildings

Persontel Monitor Trailer

Transformer Clesin and Storage Building

Samitary Water Control House

Pitsburgh Naval Reactors

Bettis (Site 1201)

AT-BAT Complex

MEL and Alpha Facility

F.Shop

G-Building

L-Builting

N-Complex

C-CA-CAM Complex

Hangar \#2

Rotoclone Bullalins

CY-Bullding

J-Builking

E-Building

Matin Guart Station

NRF (Site 1202)

Expended Care Facility

SIW Prototype

Richland Operations Office

2 River Pump Houses

2 Reservoir/Fump Houses

Filter Building

2 Main Pump Houses 
Solvent Storage

Filter Plant

2 Developenent Labs

Main Process Pump House

Process Pump House Annex

Storage Pump House

Process Pump Annex

Vertical Rod Test Tower

2 Reactor Boildings

Power Control Boilding

2 Oil Storage Buiktings

Water Studies

Coolant Systems Development Lab

Water Studies Recirculation

Area Stop

3 Warehouses

2 Maintenance and Transportation Buildings

2 Emergency Pump Houses

Filter Houseliead House

Lime Feeder

Head HovoselChtorine

Efficent Water Monitoring

Reactor

Basin Recircolated

Chemical Putroping

Heat Exchatager Building

Steam and Flow Instrumtent

Filter Boilding

Valve Control

Chentical Waste Storage

Change and Contral

Waste Loawout

2 Valve Houses

2 Water IFants

Air Sample

Electric Switchgear

Anxiliary Power Building

Deminenalization Waer Bujiding

Oil Pump House

2 Equipment Dovelopmen Buildings

2 Warehouses

Receiving and Inspection

Hot Shop

2 Storage Buillings

2 Pump Houses

Filter Water Boulloing

Aluxiliary Power House

Auxiliary Power House Anmex

2 Separation Butloings

Waste Unloading Facility

Encapsutalion Building

Evaporation Building

Sludge Vault Storage and Processimg

RescrvoidPump House

Filis Plant
2 Power Houses

Retiox Laboratory

2 Urarium Oxiđe Plants

Piutuaium Finishing Briłling

Plutonium Rechamation Building

EFaporator Facility

Laundry and Mast Cleaning

ReservoirPump House

Filer Plant

Exhaust Air Flter Stack

12 Metered Process Buildings in Area 400

1 Metered Process Bvilding in Area 600

Rat. Mt. Pump House

A.L.E. Pump House

Savantah Ritser Operotions Office

3 Pumphouses

4 Reactor Builings

4 Area Cooling Water Pumphouses

4 Area Fuel Unloading Facillites

4 Emergency Diesel Generator/Fiel Oil Storage

Facilities

Schenectady Naval Reactors

Knolls Test Computor Facility

Kesselring Prolotype and SEB

Windsor Prototype and SEB

Noval Petrolewm and Oll Shale Reserves in Colorado, Vitat, and Wyoming

Maintenance Shop

LTS Gas Plint Main Compressor Builaing

Steam Generator \#1 Facility

Warehouse Qnonget

Water Trealment Facility

North Waterflood Plamt

Steant Generator \#2 Faxility

Steam Generator \$3 Facility

Steam Genteralor \#4 Facility

Steam Generator \#5 Facility

Field Operations Office

Envinomental, Safety, and Healh Office

Water Treaiment Facility Expansion

UPS Bujkling

LTS Gas Plant Office

Periphtal Waterflood Plent

LTS Gas Plant Shop

Polymerflood Plant

LTS Gas Plan PAMCO Building

LTS Gas Plant Lab

LTS Gas Ptant Punu House

Freflood Pump Building 
South Texminal Main Buildlng

Main Gave Guord Shack

South Gate Guard Shack

\section{Strategic Petroleum Resterve Project Office}

Barou Choctaw Facility

Admintistration Building

BLDG, MSRMT and Test Equipentent Storage

Control Building

2 Filter Storage Trailers

Flamriable Storage Building

Foam Desludge Building

Foam Storage Building A

Guard Howse, Main Entrance

Instrwient Stop Building

Maintenance Building

Potable Water Filtration Building

Property Warthouse Building

RWLS Pwnp House

Security Operations Cexter

5KVA Switchgear Building

Gon Clearing Building

Big Hill Eacility

Administration Facllity Butlding

Control Center Office Building

Covered Laydown Building

DOE Construction Builting

Firewater Pumphouse Building

Foem Proportioning Btilding

Gatebouse \$3

Hardened Gatehouse Front

Sample Storage Builđing

Vebicle Maintenance Building

Warehonse/Maintenance Building

Wash Rack Building

Wheeled Equipment Storage Building

Hardeped Guarcthouse RWS Building

Substation Buildimg

Control RWIS Building

Microwave Building

Security Operations Center

Communications RWIS

Bryan Mound Facility

5KV Switchgear MCC F\&G Btilding

Adninistration Building

Control Office Buildiong

Electrical Shop

Electrical MCC Building

Fire Expoipment Strorage Building

Fire Pump on RWS

Flammable Stocage Building

Foam Generator Building
3 Foam Storage Buildings

2 Guard Houses

Maintenance Facility

Radio Repeater Building

Substation Electrical Building

Warehouse Rec. Boilding

2 5KV Switchgear Builtings

HPP/PermitFire Pump Building

Audit Trailer

Property Trailer

Quality Assurance Trailer

Security Trailer

Storage D Trailer

SOC Building

MCC Building

St. James Facility

Admintsstration Buiking

Control Center Building

Flammable Storage Building

Foam Deluge Bnilding

4 Form Ptop. Facilities

2 Guard Houses

Laboralory

Maintenance Receiving Building

Radio Tower Boilding

Spare Parts Warebouse

Fire Pump House DKI Butlding

Foam Prop. Building

Foam Prop. Building, Dock 2

Operator Building, Dock 1

Operator Building, Dock

5KV Switchgear Bulloing

Gun Clearing Building

Sulphur Mines Facility

Control Center Burilding

2 Form Storage Buildings

Trailer Guard House

Gun Clearing Building

Security Ops. Center Building

Worehouse 2 Building

4 Mobile Trailers

5 Trailers

Weeks Island Facility

Frrewater Pumphouse

Aduinistration Building

Contral Building

Equijument Storage Building

Fill Site Storage Building

Fire Transformer Del. Building

Fire Truck Building

Flammable Storage Building 
Guardbouse LDWN Building

Guv Clearing Buttding

Hose Reel Building

Inert Gas Generalor Buitding

MCC3 S/S Area Bulikding

PS Guardhutuse

PS Heat Frame Building

P/S Hoist and MCC Building

Pump House Foam Building

SS Guardhouse

S/S Head Frame Building

S/S Hoist Building

Sanple Lab Building

Warehouse Building

Well Water Pung House

SKV Switchgegr Building

Construction and Mainterance Building

Guard House

West Hackberry Facility

RWIS Computer Control Bojlding

Communications Building

Control Center Bojlding

Filn Storage Building

Fire at Black Lake Building

Foam Desludge Building

Foam Generator Buildting

3 Foam Sionage Butlidings

Guarithouse SOC Building

Mrin Fire Water Building

Maincenance and Warebouse Building

Warebouse Building

Administration Building

Guard Construction Gate Bujlding

Microwave RWIS Building

7 Trailers

Property Warehouse A

UPS RWIS Building

Gun Clearing Building

RWIS Building

Switch Gear Building

FRRMI Nattonal Accelerator Laboratory

Feyramian Computer Facility

Cooling Ring

3 Service Buildings

Target Hall

Gas statage Building

Booster Gallery East and West

2 Booster Towers

Acceletator - Linac, X-Gallery

Certral Utitity Building

6 Kicker Buildimgs

Lab Building
Service Building/Vehicle

30 Service Butldings

Pump House

Vehicje Access Builting

2 Power \$upply Buildings

Switchyard Service Building

24 Refrigeration Buildings

Collider Detector Facility

Assembly Butlding

Meson Wonder Enclosure

5 Meson Service Builillings

Messon Detector Builking

Meson Central Cyrogenies

Meson Assembly Building

Meson West Lab

Polarized Proton Lab

Meson Counting Bülơng

Prolon Pagoda

Prolon Assembly

Proton Taggen Photon

High Intensity Laboratory

6 Proton Service Boildings

Pratón Pole Buiłding

Exp Area operations Ceater

5 Nevurino Labs

Laboratory $F$

Laboratory 9

Neutrino Lab WWA

5 Neurino Service

Neutrino Target Service

Wide Band Lab

PB6/PB?

Muon Laboratory

4 Industrial Buildings

Industrial Shed

Industrial Center

Industrial Compressor Building

Magnet Storage

Central belium Liquifier

Master Sob-Station

Cascys Pond Pump House

Whison Halt \& Auditorium

Science Education Bldg

11 Sauk Circle

1 Sauk Circle-Residence

3 Sauk Circle-Dorm 7

4 to 19 Sauk Circle-Residence

1 Sauk Blyd-Aspen East

I4 Sauk Blvd-Ressidence

I5 Sauk Blvd-Restidence

I8 Sauk Blvd-VendingLaundry

20 Sauk Blvd-Residence

I Shabbona-Dorm 3

22 Sark Blvd-Residence

24 Sauk Blwa-Residence 
24A Sank B]wd-Garage

26 Sauk Blyd-Residence

28 Sauk Blvd-Residence

28A Sauk Blvd-Garage

28B Sork BIvd-Greenhorse

28C Sauk Blvd-R\&G Equipment Shed

29 Suat Blvd-Residence

30 Sauk Blvd-Matd Hdquts

30A Sauk Blyd-Pole Building

31 Sauk Blvi-Pump House

32 Sauk BIvd-Dorm 1

33 Sauk Blwd-Resideace

34 Sank Blwd-Residence

36 Sank Blyd-Metals Dev.

2 Che Che Pinqua-Users Center

1 Che Che PinquarKubn Barr

13 Neuqua-Residence

16 Netrua-Resilience

18 Neuqua-Residence

19 Neuqua-Residence

20 Neuqua-Lab 7 House

22 Neuqual Lab 7 House

23 Neuqua-Residence

25 Neunuar-Residence

26 Neuqua-Lab 6 House

26A Nenqui-Lab 6-Garage

28 Newquatab 6 House

30 Neuqua-Lab 6 Honse

28A Nenqua-Lab 6 Pole Building

32 Nenqua-Lab 6 House

34 Neuqua-Lab 5 House

36 Neuqua-Lab 5 House

36A Neuqua-Lab 5 Pole indg

38 Neruquatab 5 House

36 Shabhona-Lalb 5 House

27A Winnebago-Lab 1 House

27B Winabjago- Lab 1 House

27C Winnebago-Lab 1 House

29 Winnebago-Machine Repair

32 Winnbago-Lab 4 House

35A Winnebago-Lab 2 Compressor

40 Shabbona-Lab 4 House/Ofifice

30 Winnebago-Machine Repair

22 Blackhaswk-Restidence

25 Blackluawk-Residence

24 Blackhawk-Lab 8 House

25 Blackbawk-Lab 8 House

25A Blackhawk-Lab 8 South

27 Blackbawk-Lab 8 House

29 Blackhawk-Residence

31 Blackbawk-Lab 8 House

31A Blacklawk-Lab 8 North

33 Blackhawk-Lab 8 House

35 Blackbawk-Residence

2 Shablona-Dorm 2
8 Shabbonta-Residence

8A Sinabona-Garage

10 Shabbona-Residence

12 Shabbona-Residence

14 Shabbona-ES\&H House

14A Sbabbona-ES\&H House

19 Shabbona-Residence

20 Shabbona-Shelter

21 Shabbona-ES\&H Howse

CURIA I-34 Shabbona

33 Shabbona-Residence

35A Strabbona-Lab3 House

35B Shabbona-Lab 3 House

35C Shabbous-Lab 3 House

35D Shabbona-Lab 3 House

35E Shabbona-Lab 3 House

37A Shabbona Materiat Dev. Iab

37 Shabbona Material Dev. Lab

39 Shabbona Material Dev. Lab

11 to 15 Potawatomi-Residence

15A Potawatomi-Garage

16 Potawatomi-Shower Rooms

16A Potawatomi-Exercise Rooms

16B Potawatomi-Gym

17 Potawatomi-Residence

17A Potawatomi-Garage

18 Potawatomi-Residence

20 Potawatomi-Dorm 4

20A Potawatomt-Dorm 4

22 Potawatomi-Residence

24 Polawatomi-Residence

27 Winncbago-Lab I

35 Winndbago-Lab 2 Butler Bldg

35 Winncbago-L_ab 3

38 Shabbona-Lab 4

36A Shabbona-Lab 5 Butler Bldg

32A Nenqza-Lab 6 Butler Bldig

22A Neqqua-Lab 7 Buler Bldg

27A Blacknawk-Lab 8 Butter BIdg

AP30 Service Building

AP10 Service Bldg

APS0 Service Building

APO Target Hall

APSO Gas \$torage Bdg

Boposter Gallery East * West.

Booster Tower SW

Booster Tower SE

Accelerstor-LINAC,X-Gallery

Central Utility Bldg

AO Kicker Bldg

AO Lab Bldg

AO Service Bldg/Vehicle

A1 to A4 Service Buildings

B0 to B4 Service Bldgs

B48 Kicker Bldg 
CO wo C4 Service Bldg

C17 Kicker Bldg

C48 Kicker Bidg

D0 to D4 Service Bldg

Da Vehicle Access Bkg

D48 Kicker Bldg

E0 to E4 Service Blds

E17 Kicker Bldg

F(RF) o F4 Service Bldg

F23 Power Suppty Bldg

F27 Power Supply BIdg

Switchyard Service BIdg

A1 to A4 RF Bldg

B1 60 B4 RF Bldg

C1 to C4 RF Bldg

NEUTRTNO Lab D-G

NEUTRINO LAb NWA

NEUTRINO Service $* 0$ to $t 4$

NEUTRINO Target Service

WIDE BAND LAb

PB6PB7

MUON Lab

Industrial Bldg \#1 to $\$ 4$ (\$2B)

Industrial Center

Industrial Compressor Bldg

Lawrence Berkety Laboratory

Advanced Light Source

Electronic Instramentation, Life Sciences

Utilities Service

Compressor Building

Systems Engineering

Accelerator Development, AES, RTSS

Physics, Information \& Computer Science Service

Center

Bevallachevalion

Bevatron Experimedial Area

External Particle Beam Hall

2 Accelerator atod Fusion Research Bultilings

Energy \& Environment, Nuclear Science

Chemical, Earth, Life, \& Nuclear Sciences

Center for Beatr Puysics

Naclear Science, Applied Science, and Earth

Sciences

Nuclear Science, Materipls and Chemical Sciences,

Earth Sciences

Heavy Ion Linear Accelerator (HII,AC)

HIL AC Rectifier

HILAC Anmex

National Center for Electron Mistoscopy (NCERM)

High Volmge Electron Microcope (IFVEM)

Atomic Resolution Microscope (ARM)

ARM Support Laboratory

Atmospheric Researcb Center
Liquid Gas Storage

Lower Punip House

88-Inch Cyclotron

Blackberry Canyon Galebouse

Biomedical Facilities

Bevatron Ftumbers Storage

Bevatron Electricians Strop

Bevatron Electrical Storage

3 HISS Boiłdings

VAX Trailer, User Facifity

Bevalion Trailer

Bcvalec Patient Facility

Life Sciences

Office Trailer

Electromics Enginetring, Conputer Sciences

Compressor Shelter \& Storage

Flammable Gas/Liquid Storage

Entergency Generator

Bevatron Riggers

2 AFR Experimental Studies

Chemical Sciences

AFR, Chemical Sundies

6 Office Trailers

Energy Technology Engineering Center

MG Building, B/461

SPTF, B/462

TIF, B/013

LLTR, BNOS9

SCTI, BAS6

LMDL-1, B/032

LMDL-2, B/057

SCTL, B/026

HTF, B/B63

CHCF, B/463

Westem Area Power Administration

10 Buildings, Pboeníx

10 Buildings, Sacramento

45 Butldings, Billings

II Buildings, Sait Lake City

30 Buildings, Loveland 


\section{Department of Transportation-Federal Aviation Administration}

62 Automated Fight Service Sations

Atrport Infonmation Desk

Automated Intemalional Fight Service Statiou

119 Approach Light Systents

Atrway Beacon

127 Air Route Survelliance Radar .

FAA and Militiry

Air Route Traffic Coutrol Center

189 Automaled Radar Temtinal Systems

23 Aiport Surface Detection Equipment

647 Altheter Setting hdicaws

263 Airport Survelillance Radar *

FAA and Miltary

568 Airway/Termmal Building Maintenance

23 Air Traffic Control Beacon Interrogator

331 Air Traffic Control Radar Beacons

464 Airport Traffic Control Towers

398 Automatic Terminal Information Systems

356 Automated Weatber Observing Systems

Aerial Tranway

597 BRTE Radir Indicator Terminal Equipmeut

294 Backup Energency Communications

116 Computer Based Instruction

2 Central Computer Complexes

120 Closed Chroult TVs

229 Common Digitizers

10 Cloud Hejght Indicalors

Computer Display Channel

Combined CenteriRAPCO

11 Control Circuit Equjpment

407 Control Line Mainterance

17 Communications Microwave Link Terminats

23 Command Commutications Outlets

Center Bailling Maintenance

23 Direct Access Rafar Charmels

Display Cuannel Complex

337 Direction Finders - VHF

226 Direction Funder Isdicators

584 Distance Measaring Equipment

51 Distance Measuruing Equipment Remainiug

558 Data Multiplexors

811 Data Terminal Equipment

En Route Antomated Radar

Tracking System

5 Electronic Data Processing Systems

468 Electrical Distribution Systems

12 Emergency Operating Facilities

50 Flight Data Entry and Printout

23 Fight Data InputiOuptut Centers

391 Filight Data lnputoutput Remotes

Flight Data Remoting System Intermediate

Fields and Landing Areas
39 Fan Markers

20 Flight Service Data Processing Systents

189 Flight Service Stations

46 Ground/Ain Transmitter Receivers

Guidance Light Facility

Gap Filler Radar

85 Geostalionary Operational

Evvironmental Satellite Systems

864 Glide Slopes

1143 Homing Radio Beacons

5 Central Heating Faciltities - Per Unit

22 Heliports

Horming Ratio Beaccon - High Power

1 Intertational Aeronantical

Telecommmunications Switching Center

260) Integrated Communicalions

Swisching Systems

26 Identification, Fitend or Foe

International Flight Service Station

International Filght Service

Transmitter Station

81 Inner Markers

136 VHFIJHF Link Terminals

23 Localizer Type Directkongl Akts

20 Lead-in Light Facilities

37 Living Quarters

114 Low Lerel Wind Shear Alert Systems

Compass Locator at the ILS

Middle Marker

4 Link Repeaters

1053 IIS Locafizers

473 Compass Locators at the ILS Outer Marker

94 Medium-Intensity Approach

Lighting Systems

633 Medium-Intensity ALS (MALS) with Ronway Alignment Indicator Lights (RAII)

4 Meteofological and Aeronautical Presentation Systems

9 Marime Equiputent Boats and Docks

625 Multichanal Recorders

17 Military Height Finder Radar

33 Military Interface Groups

Military Interface Modification

272 Microwave Landing Systems

Aximulh

160 Microwave Landing Systems

Back Aximuth

271 Microwave Lamding System Distance Measuring Equipment Precision 
276 Mcrowave Landing System Elevation 1 Microwave Landing System Flare 828 Midale Markers

14 Mobile Laboratories 105 Mode SData Links 46 Maintenance Processing Systems 400 Mobile Engines or Genenztor Plants 28 National Data Interchange Networks 1282 National Radio Communications Systems 39 Next Generation Weather Radar 65 Off Airways Weather Stations So Omnidirectional Airport Lighting Systems Ocearnic Display and Planning System 325 Heavy Equipment and Off-Road Vebicles 831 Outer Markers

General Oil Distribution System 180 Precision Approach Path Indicators

2 Precision Approach Radar 707 Power Condjtioning Systems 19 Primary Power Engines or Generator Plants 68 Quarters Building - Other than Living Quarters 8 Redar Approach Control - Air Force 111 Rotating Beam Ceilometers 11 Radar Brigbt Display Equipment 22 Radar Beacon Data Processor Equipenent 277 Remoto Beacon Performance Monitor 685 Remoto Cenler Air/Greund

Communications Facilities 99 Reanote Control Interface Units 752 Radio Communications Link Repeat 233 Ratio Communications Link Teminals 1837 Remote Communications Outlets 692 Rumway End Identification Lights 215 Remote Montitor Control Facilities 214 Radar Mictowave Link Repeaters 138 Radar Mierowave Link Terminals 189 Remote Readovt Hygnotiermometers
95 Radar Remote Weather Display Indicators 135 Radar Remote Weather Display Systems 12 Remote Tower Communications Control Systems

1222 Remote Transmiltuer Recelvers 537 Runway Visual Range Shortered Approach Light System

Sanitation System

661 Storage Buildlogs

Systems Command Ceater

Sensor, Receiver, and Processor

72 Simplified Short Approach Lightims

Systems with Rumaway Alignment

Indicator Lights (RAII)

Simplified Stort Approach Lighting System

Self Sustained Outlet

49 Sewerage Systems

666 Taxtical Air Navigation

8 Tower Cos Digital Displays

144 Terminal Dota Display Systems

496 Telephone Exchanges

589 TELC Interface Majatenance

19 Terrinilal Information Processing Systems

125 Television Microwave Link Indicators

110 Television Microwave Link Repeaters

138 Television Microwave Link Transmilters

414 Tower Buildings

529 Trails and Roads

25 Terminal Radar Approach Controls

17 Teletypewriter Facilities

137 Transcribed Weatser Broadcast

743 Utility Building

1387 Visnal Approaxh Slope Indicators

769 Vehicle Mairteanonce

1025 VHF Omnidirectional Range

95 VHF Omnidirectiontl Range Test

Weather Massage Switching Center

Water System Maintenance

\section{General Services Administration EXCLUDED GSA OWNED AND OPERATED BUILDINGS}

GSA CD Depot 234, Watentown, MA

Federal Bldg USCT, Worcester MA

US Border Station, Calais, ME

US Bordex Station, Coburn Gore, ME

US Borier Station, Fort Faiffield, ME

US Border Station, Fivolton, ME

US Border Station, Jackman, ME

US Border Station, Limestone, ME

US Border Stzation, Orient, ME

US Border Station, Vanceboro, ME

US Border Station, Van Beren, ME

US Border Statinn, Calais, ME
US Border Station, St Francis, ME

US Border Station, Madawaska, ME

US Border Station, Hodgdon, ME

Parking Facility, Porlland, ME

US Border Station, Fort Kent, ME

GSA Reg. FSS MP, Concord, NH

US Border Station, Derby Line, VT,

US Border Station, Highgate Springs, VT

US Border Station, Norton, VT

US Border Station, Beere Plain, VT

US Border Station, Alburg Springs, VT

US Border Sation, North Troy, VT 
US Border Station, West Berkshire, VT US Border Station, Derby Line, VT

US Border Station, Becher Falls

US Border Station, Comean, VT

USBS East Richford, Richford, VT

US Border Station, Richiord, VT

USBP Sector HEQTRS, Swanton, VT

Administration Bldg, Champlain, NY

Inspection Bldg Borter, Chateaugay, NY

Temp Frme Gar Bdr St, Massena, NY

Inspection Bldg, Mooess, NY

Border Station, Fort Covington, NY

Border Station, Rouses Point, NY

Border Station, Rouses Point, NY

Border Station, Tront River, NY

Administration Bldig, Alexandtla Bay, NY

Boltway Bldg, Woodlaph, MD

Bldg. No. 1, Bene-Mead, NJ

M.H. Cohen US Courthouse, Canden, NJ

Cedar Crest Pro Park, Allentown, PA

Teasury Facility, Philadelphia, PA

Matnlenance Building, Wilkes Barre, PA

FARC, Chicago, IL

GSA Interagency Motor Pool, Chicago, IL

Fed Building \& US Courthouse, Urbana, IL

Fed Supply Depor Chicago, II.

US Border Station, Saule Ste Marie, MI

Fed Parking Facilty, Detroit, MI

Cust Cargo Inspec. Fac, Detroit, MI

Border Station, Grand Portage, MN

Custom \& Immigration Siation, Noyes, MI

Border Station, International Falks, MN

Federal Bldg, Zanesville, $\mathrm{OH}$

Federal Parking Facillty, Dayton, OH

Fed Butlding \& Courthouse, Youngstown, OH

Building 87, Fort Des Moines, IA

Fed Building, Wichica, KS

New US Courthouse, Kinsas City, KS

T-Hangar " $\mathrm{G}$ ", Grand Island, NE

FOB/CTHS Complex, Baton Rouge, LA

USBP SH Bldg 13, New Orlears, LA

Federal Bldg USPO, Jonesboro, LA

Open Land-FDA Site, New Orlears, LA

US Federal Courthouse, Shreveport, LA

Border Station, Columbus, NM

Border Station, Santa Teresa, NM

Feteral Bldg, Tulsk, OK

Gateway USBS, BLDG A, Brownsville, TX

BPSH Bldg 1 HQTRS, Del Rio, TX

BPSH Bhy of the Amers, El Pasa, TX

BPSH Bidg A, Laredo, TX

BPSH Admin, Bldg., McAllen, TX

HQTRS Bldg, Marfa, TX

USBS Paso Del Norte, El Paso, TX

USBS Main Bldg, El Paso, TX
US Appraisers Stores, Houston TX

US BS, Laredo, TX

USBS, Eagle Pass, TX

USBS, Del Pio, TX

Juartz-Lincola USBS, Laredo, TX

USBS, LOS Indios, TX

USBS B\&M Bridge, Brownswille, TX

USBS Good Neighbor, El Paso, TX

Byron While US Courthouse, Denver, $C O$

GSA Parking Lot, Denver CO

Chief Mm BS \& Quarters, Babb MT

Piegan BS \& HQTRS, Babb, MT

Roosville BS, Eurekn, MT

Sweetgrass BS, Sweetgrass, MT

BDR Patrol Sector HQ, Havre, MT

Ambrose BS, Ambrose, ND

Dunseith BS, Dunsetth, ND

Portal BS, Portal, ND

St John BS, St John, ND

Pembina BS, Pembina, ND

BDR Parrol HQTRS, Grand Forks, ND

Garage, Cheyenne, WY

USBS, Lukeville, AZ

BS Office Bldg, Nogales, AZ

BS Garage, Sasabe, AZ

BS Main Bldg, Douglas, AZ

BDR Patrol Sector HQTRS, Tucson, AZ

BS Main Bldg, Sart Luis, AZ

BS Main Bldg, Naco, AZ

BS Office Bldg, Nogales, AZ

Tucson L.E. Srite, Tucson, AZ

BS Old Customs Bldg, Calexico, CA

BS Exist Maio Błdg, Sm Diego, CA

BS Main Bldg, Andrade, CA

New Cornmercial Fac, San Diegor CA

BS Maí Bldg, Tecate, CA

J.Woinberger US CTH, San Diego, CA

Phillip Button Fed Bldg, San Francisco, CA

US Border Patrol Station, Calexico, CA

San Jose Chse \& FB, San Jose, CA

Parking Garage, Los Angeles, CA

Oakland Fed Bldg, Oakband, CA

Dalton Cache BS, Haines, AK

Station Bldg, Tok, AK

INT AG Motor Pool, Anchrorge, AK

Skagway Border Station, Skngway AK

USBS, Festport, ID

US Border Station New, Porthil, ID

Fed BIdg, US Cinse, Boise, ID

Station Bldg, Blaine, WA

Station Blde No 2, Blainh WA

Danvilte Border Stalion, Danville, WA

Station \& Quarters, Curlew, WA

USBS, Lautier, WA

USBS, Metatine Falls, WA 
USBS, Oroville, WA

USBS, Sungs, WA

Ken G. Ward BS, Lynden WA

Federal Building, Olyunpia, WA

USBS, Point Roberts, WA

Fed Office Bldg., Seattle, WA
Fed BIdg US Post Off, Spokane, WA

Border Patrol Sect HQ, Bline, WA

Bor Patrol HQ Annex, Blaine, WA

Bord Patrol Sect HQ, Spokane, WA

White House, Wasbington, DC

Delassalle, Avomdale, MD

\section{GSA EXCLUDED LEASED BUILDINGS}

33 Corinth Ave, Boston, MA

4 Copley Plase, Boston, MA

One Center Plaza, Boston, MA

USBS Township 15, Saiut Francis ME

USBS Towiship 2C, Saint Francis ME

USBS Township 11, Saint Francis ME

USBS Township 15, Saint Francts ME

Fleet Center, Providence, RI

The West Pavilion, Providence, RJ

Swanton Buitdings, Highgate Springs, VT

Gatsway I, Newark, NJ

Innovation Plaza, Little Falls, NJ

WS Jamiesons Line, Burke, NY

609 W. Washington \$t, Geneva, NY

67-10 Myrtle Ave, New Yok, NY

617-619 Beach 29 St, New York, NY

5 Washington Square, Albany, NY

Greenway Plaza, Melville, NY

76 Eleveoth Ave, New York, NY

Federal Centre, Buffalo NY

Yassar Main Bidg, Poughkeepsie, NY

Starret Lehigb, New York, NY

28-18 Steinway St, New Yoik, NY

Metrotech Center, New Yor, NY

27 Peunsylvamia Ave, New York, NY

Playtoggs Plaxa, Middletown, NY

Sta Maria Exec Hall, Porce Porce, PR

Braddock Square Mall, LaVale, MD

American Enterprise, Ewing Twnshp, NJ

1000 Califomia Ave, Pittsburgh, PA

Gateway, Philadelphia, PA

Wise County Plaza, Wise, VA

2914 Horgary Spring, Richmond, VA

610 West Office Pk, Fredericksburg. VA

Hampton Warehouse, Hobtington, WV

915 Weinacker Ave, Mobile AL

500 Building, Bimingham, AL

2206 Buililing, Miami, FL

611 Arrman Bldg., FL. Lavderdale, FL

David Moss Bldg., Miami, FL

Norman Berry Bidg, East Point, GA

MTS Texhwood, Allanta, GA

2250 Newmarket No. 11, Marietta, GA

Jadicial BIde, Btloxi MS

Besufiont Courthouse, Beaufort, SC

Ore Oak Brook Ter, Oak Brook, IL
Xerox Centre, Chicago, II

Stewart Square, Rockford, II 635 Butterfield Rd, Oakbrook Tetrace, IL Governors Off PK IV, Olympia Fields, IL Gkenwood Plaza, Glenwood, IL

Business Centre Bldg, Oakbroak Terrace, IL

Northwestern Bldg, Evanston, II.

The Rookery, Cbicago, IL

Heritage Place, Moline, it

1600 Corporate Center, Rolling Meadows, IL

4849 N Milwauke Ave, Chicago, IL

AT\&T Corporats Center, Chicago, IL

801 Warrenville Road, Lisle, IE.

100 Tower Lane Bldg, Bensonville, II

Olympisn Office Center, Lisie, II

The Pk at NW Point, Elk Grove Village, IL

945 Lakevietw Pkwy, Verion Hills, IL

1110 MoConnell Road, Woodstock, II

2860 River Road, Des Plaines, II

2124 Greenbay Rosd, Evanston, IL

Fox Rjver Center, Ottawa, IL

Lakeside Ofc Bldg. Indiamapolts, IN

Pendleton Trade Cntr, Indianapolis, IN

429 Penn Center, Indianapolis, IN

The Furoilure Co, Grand Rapids, MI

Han Building, Owosso, MI

Ambassador Bridge, Detroit, MI

Arlington Plazs, Sault Ste Marie, MI

Good Speed Building, Grand Rapids, MI

5015 South Cedar St, Lansing, MI

Donnino's Farm House, Anri Arbor, MI

Brewery Park Phase I, Detroit, MI

Gateway Business Ctr, Roseville, MN

Atrium Office Plaza, Cleveland, OH

Pleza Nine Bjdg. Cleveland, OH

Center West Office, Rocky River, OH

Tenayson Guyer FB, Lima, OH

Commerce Place, Middleivurg Heigbis, $\mathrm{OH}$

Plaza Sonth II. Middleburg Heights, $\mathrm{OH}$

Sanning Aparments, Cincinnati, OH

One Cleveland $\mathrm{Ct}$, Cleveland, OH

Lakewood Center West, Lakewood, OH

2026 West Main Street, Springtield, OH

113 St Clair Ave, Geveland, OH

Bankers Building, Chicago, IL

Fed Hwy Adm Reg Off, Homewood, II. 
Gilen Mill Ofe Pk, Glen Elyn, IL Social Security Bldg, Daanville, II. OHare Oftrce Blds 2, Rosemont, II Park Ridge Office Centes, Park Ridge, IL OHare Lake Ofe Pla, Des Plaines, Il. Mid-Continealal Pla, Chicago, II Insurmce Exchenge Bldg, Chicago, it Plaza Tower Office, Evergreen Park, IL Clyde Savings Bldg, North Riverside, IL 2100 N Califormia, Chicago, IL Wash Bicentential Bg, Springfield, IL Smoke Tree Bus Park, N Aurora, IL Glen Hill North Bg, Gien Ellyn, IL County Bank Plaza, Utbana IL Trans Union Bldg, Chicago, IL 10 West Jackson Blyd, Chicago, IL Farnsworth Center, Anrora, IL. O'Hare Lake Of Pla, Des Plemines, IL One Congress Center, Chicago, II E Empirs \& Eastport, BIownington, î Barrell Building, Chicago, II Oakmiont Corporation, Westmont, IL. 1455 Golf Mill Road, Des Plaines, IL 203 North Vine, Urbang, II 1279 North Milwankee, Chicago, II Bark of America, Chicaso, IL 901 Warmenville Road, Lisle, IL 1700 South Wolf Road, Des Plaines, IL. 175 East Hawthom Pk, Vemon Mills, IL Quail Ridge Oft Center, Westmont, IL. Elm Plaza So Tower, Hinsdie, II. Soc Sec Office, Chicago, II. 125 Fairfteld Way, Bloomingdale, IL IL Busimess Center, Springfield, $\mathbb{L}$ 2360 E Devor Ave, Des Plaimes, 1 923-25 Dillon, Wood Dale, IL Glen Hilt North Bd, Glen Ellyu, II River Center, Chicago, IL. Schaumburg Atrium, Schammburg, IL 600 Joltet Rd, Willobrook, IL 2350 E Devon, Des Plaines, IL Gateway IV, Chicago, IL Citicorp Center, Clicago, II Liberty Business Pa, Elk Grove Vilage, I. $29 \mathrm{~N}$ Wacker Dr, Chicago, IL Governors Off Park, Olympia Fields, IL Norti Point Tower, Cleveland, $\mathrm{OH}$ Warehouse 3, Dayton, OH Bank Ope Center, Cleveland, OH Eaton Center, Cleveland, OH Wright Exectutive Cr, Fairtorn, $O H$ Renaissance, Cleweland, OH 228th \& Lake Shore Blvd, Euclit, OH Society Tower, Cleveland, OH 6161 Oaktree, Itideperdence, $\mathrm{OH}$
Old Bayield Clise, Bayfield, W

Soc Sec Office, Wisconsin Rapids, WI

Vander Heyden II, West Bend, WI

575 Lester Street, Onalaska, WI

Kirschling Offices, Wausau, WI

301 High Ave E, Oskaloosta, IA 323 12 E College St, West Branch, IA Rosana Square 7720, Overland Prak, KS 1103 Sovthwest Blwi, Jefferson City, MO

VA Building, St Lovis, MO 1319 Dielman Roed, St Louis, MO St Louis Busimess Ctr, St Louis, MO 14-15 St Cass-Chicago, Omaba, NE Portion Lots 8 to 12, Little Rock, AR Unnamed Bldg, For Smith, AR Unnarled Bldg, Metgirie, LA Blds 27, Houma, LA

Sun Belt Bus Crr, Albuquerque, NM SSA District Office, Polean, OK Kiag Building, Consicana, TX 3223 Briarpark Bdlg. Houston, TX Unnarted Building, Housion, TX Regency Building, San Antonio, TX US Border Station, Presidio, TX Unsamed Blde, Laredio, TX Unamaned Blig, Adalison, TX T\&P Building, Fort Worth, TX IRS/ACS Facility, Englowood CO Tatum Parking Lot, Helena, MT 1560 Juliesse St, Sacramento, CA 39176 State Street, Frenont, CA Motar Pool, San Francisco, CA 874 E Hobsonway, Blythe, CA 327 W 2nd Street, Calexico, CA Parkway Centre, Alameda, CA 1818-C Amold Ind Pl, Conorid CA 200 Kanoelebua Ave, Hilo, HI The Portals, Washington, DC Peun 17, Wasilington, DC 701 Lamont St NW, Washington, DC 1800 G Street NW, Washington, DC 1919 M Street NW, Washibigton, DC MD 50 Induscial Center, Landover, MD So Maryland Courtuouse, Grembelt, MD SS Metro Center 4, Silver Spting, MD 12225-12231 Wilkins, Rockville, MD The Hamptous, Capitol Heights, MD SS Melro Center 3, Silver Spring, MD $301 \mathrm{~N}$ Stonestreet Ave, Rockville, MD 12100 Parklawn Dr, Rockville, MD 4934-40 Boil Brock, Rockville, MD AwM Building, Arlington, VA Hunter Building, McClean, VA Metpar, Falls Church, VA Kimberly Bldg, Sptingfield, VA 


\section{National Aeronautfes and Space Administration}

\section{Johson Space Center}

Flight Operations Facility

Fighte Operations

Mission Simulation Training Facility

Crew Systems Laboralory

Photographic Technology Latoratory

Central Data Office

Aviotics Systeris Laboratory

Central Heating \& Cooling Pant

Anxiliary Chitler Facility

Mission Control Center - Houston

Planetary \& Earth Sciences Laboratory

Space Euvironment Simnlationt Laboratory

Mission Simulation Development Facility

Life Sciences Laboratory

Central Computer Fecility

Energency Power Building

Vibration/Acoustic Test Facility

Aumos. Re-Entry Materials \& Structures Eval. Fac.

Radiant Heat Facilicy

Thermochemical Test Area

NASA Industrial Plant (Downtey) and USAF Plant

42, Production Site I (Palmdale)

Entire Facilities

White Sands Test Facility

Entire Facility

\section{Xennedy Space Center}

Hanges S, Automated Paylaad Facility

Hanger L, Life Sctences Support Facility

Spin Test Building

Instrumentation labozatory

Hangar AO, Spacecraft Building \#2

Hangar AM, Spacectaft Building *1

Hargar AE, Míssile Assernbly Building

Hanger AF, SRB Recovery Building

SRB Paint Building

SRM X-Ray Facility

Landing Aids Control Building

Rotatiog/Processing Building

Ortxiter Modification and Refubishment Facility

Thermal Protection Facility

Vehicle Assembly Buikding

Orbiter Processing Facility

Iaunch Control Center

Uitity Annex
Processing Coatrol Center

Repeater Station

ConverterflCompressor Building

Propellant Laboratory and LP/HP Gas Facility

Manufacturing Building

Laupch Complex 39 A\&B

Communication Distribution \& Switching Cetter

Operations Bullding

Operations and Checkout Building

Space Station Processing Facility

Payload Support Building

Launch Equipment Test Faciety

Parachure Refurbishment Facility

Canister Rotation Facility

Hypergol Madale Process North

Hypergol Support Building

Spacecraft Assembly \& Encapsulation Facility

Hypergol Module Process Soulh

Payload Hazardous Service Facility

Vertical Processing Facility

\section{Marshall Space Flight Center}

Microwave Anechoic Chamber

Commonications Facility

Ptootographic Laboratory

Hardware Simulation Labonatory

Celestial and Optical Sensors Facility

Power Systems Laboratory

Avialion Simulation Laboralory

Space Science Laboratory

Laboratory \& Office Building

Test Support Butlding

Propulsion System \& Comp. Alditude Test Facility

Acoustic Model \& Comp. Test Facility

Structural Test Facility

Test Facility Termitial Building

Hot Gas Test Control/Support Building

Test Control and Service Building

TPTA Refunbishment Facillity

Pung and Boiler House

Propulsion and Structural Test Facility

Test \& Data Recording Facility

Environmental Effects Labotatory

Materials \& Processes Laboralory

Atmospheric Research Facility

Heat Treatment Facility

Stroctures \& Mechanics Laboratory

Cryogenic Testìs Facility

Air Compresso: Building

High Pressure Test Facility

Multi-Porpose High Bay Facility 
Hydkoulic Equipment Development Facility

LH2 Vaporization Facility

High Pressure GN2 Facility

Boiler Plant

Computer Facility

Pump House

Propulsion Textuology Test Facility

Test Facility Support Building

Blockhouse

Boiler House

Helium Contiressor Buiking

Non-Destructive Evaluation I-aboratory

Shops \& Neutral Buoyancy Simulator

Productivity Enhancement Facility

Engineering \& Development Laboratory

Developmental Processes Laboratory

$X$-Ray Calibration Facility

Office and Wind Tunnel Focility

Compressed Air Facility

Air Compressot Building

High Bay Shop Buildtrg

Molti-Purpose High Bay Facility

Surface Treatment Facility

High Regnolds Number Facility

Low Deosity Flow Facilty

Engine Dynamic Fluid Flow Facility

Michoud Assembly Facility

Entire Facility

Santa Susena Field Laboratory

Entire Facility

sitdell Computer Compiex

Endre Facility

NASA Tracking Stations

Deep Space Network, Goldstonte, CA

TDRSS Ground Terminals, Whito Sands NM

STDN Site, Ponce do Lean, FL

Ames Research Center

Computational Flujd Dynamics Building

Vertical Gun

3.5 Wind Tuanel Model Builíng

12 Ft Pressure Witd Tuanel

$12 \mathrm{Ft}$ Wind Tumel Auxiliartes

Propulsion Simulations Calibration Laboratory

Balltstic Range

Flight Support Facitty
Model Devolopment Facility

$7 \times 10 \mathrm{Ft}$ Wind Tunnel \#1

$7 \times 10 \mathrm{Ft}$ Wind Twnol \#2

Model Preparrition Facility

Motel Assembly

Maguetic Calibration Labaratory

Magnetic Test Laboratory

14 Fr Transonic Wind Tonnel

14 F ElectricaI Equipment Butlding

Fan Blakde Shop

Technical Services Shop

$40 \times 80$ Ft Wiad Tunnel

20-G Centrifuge

$80 \times 120 \mathrm{Ft}$ Wind Tunued

$2 \times 2$ Transonic Wind Turmel

Electriçal Substation

Electrical Substation North

6 X 6 Supersonic Wind Tunnel

Unitary Plan Wind Tumel Btilding

11 Ft Transonic Wind Tumel

$9 \times 7$ Subsonic Wrad Tumel

$8 \times 7$ Subsonic Wind Tunnel

Unitary Pant Wind Tunnel Auxiliary Building

3.5 Ft Hypersonic Wand Tunne!

3.5 Ft Hypersonic Wind Tumne Auxiliary Building

3.5 Ft Hypersonic Wind Tunnel Storage Building

Fluid Dynamies Laboratory

Central Compulation Facility

Advanced Computation Facility

Thermal Protection Facility

Thermal Protection Boiler

Biosclence Laboratories

Hypervelocity Fres Fight Facility

Are Jet Facility

Life Sctences Research Laboratory

Life Sciences Equipment Facility

Airbone Missions:Lite Science Facility

Vestibular Research Facility

Vertical Motion Simulator

Vertical Motion Sinnulator Equipment Facility

Space Projects Facility

Space Sciences Reseirch Laboratory

Model Construxtion Facility

Aircraft Service Facility

Aircraft Service Facility

Aircraft Service Facility

RSRA Calibration Facility

Aircraft Service Facility

Outside Aerodynamic Research Facility

High Pressure Air Housing

Propane Facility

Program Support Corsmumication Network Facility

Flight Data Complex

Flight Data Pacility

Man-Vehicle Systern Rezearch Facility 
Numerical Aeromantics Simulator

High Altitude Aircraft Support Facility

Fuid Mectanies Laboratory

Biomedical Research Laboratory

Human Performanca Research Laboratory

Hazardous Material Storsge Facility

Automated Sciences Research Facility

Mission Variable Trailers

Dryden Flight Research Center

Entire Facility

\section{Langley Research Center}

Law Turbolence Tunnel \& Compressor Station

Transonic Tuanel

6 X 19 Transonic Tunnel

8 F Transosic Tumel \& Support Building

$30 \times 60$ Ft Tunnel

12 Ft Low Speed Tumnel

$20 \mathrm{Fe}$ Vert Spin Tunnel

Spin Reseanch Office Facility

East Area Compressor Station

General Rotor Aeroelasticity Lab

Transontic Dyogmic Tunael

Hydrodynamics Research Facility

East Area Storage Facility

Vortex Research Facility

Space Environment Effects Laboratory

$16 \mathrm{Ft}$ Transonic Tumel

Structures \& Material Research Lab

Pyrotectmics System - Erviromentental Test

Fight Management Research Facility

Advanced Technology Resegrch Laboratory

Aeronautic Electronics/Fligbt Dyramics \&

Costrol Lab

Materiats ResearchuLight Alloy Laboratory

Acoustios Research Laboralory

Areo Acoustics Branch Offices

Subsonic Tinnel Offices

High \$peed $7 \times 10$ \& Subsonic $14 \times 22$ Tunnels

Basic Aerodynamics Research Tunael

Steam Generation Plant

Conference Center

Anecboic Noise Factlity

Information Systems Researte Facility

Hyper Popplision Factlity

High Intensity Noise Research Laboratory

Advanced Machitre Development Laboratory

Technology Appications/Struchires Laboratory

Hazard Material Metallurgy Loboratory

Experimentiol Testing Tecitrology

Gas Flow Calibation Laboratory
Nondestructive Evaluation Laboratory

Space Systems \& Concepts Laboratory

Metals Technology Development Lahoratory

AFGE Union Builbing Local 2755

Jet Exit Test Facility

Frequency Conkerter Building

National Transonic Facility (NIF)

NTF Tuinel Model Stwrage

Models Technology Electronics Support Lab

Foundry \& Glass Blowizg Stop

Electronics Technology Laberatory

Electronics Technology/Microelectronics Dev.

Cosposites \& Model Development Laboratory

Drive Control Facility

0.3 Meter Transontic Cryogenic Tonael

Aero Systems AnalysisfFlight Ops. \& Support Fac.

Hanger Suppoit

Flight Operations Support Facility

Gas Dynamics/Fluid Mechanies Research Facility

Hypersonic Facilities Complex - West Wing

Hypersonic Facilities Complex - East Wing

High Pressure Air Facility

G0-Inch M18 Helinm Tunnel Facility

Afmospheric Sciences/Systems Development Lst.

Atmospheric Sciences Laboratory Annex

Unienry \& Comected Flow Hyper. Wind Tuntels

Aircraft Landing Dynainics Facility

Aircraft Landing Dynamics Office/Shop

HPB Ceramic Heated Combination Facility

8 Ft High-Temperature Structures

Thertial Structures Laboratory (TSL)

Materials Processing and Development Shop

TSL Cooling Syscen Facility

Cencral Scientific Computiog Faciliny

Flight Simulation Laboratory

Central Sckentific Computing Facility

Printed Circuit \& Excapsulation Laboratory

Composite Preparation Building

Composita Storage Builiting

Chemical Treatment Facility

Radialion Re-Entry Research

Engineering \& Fabrication Laboratory

Storage Facility

Component Verification Building

Cloud Chemistry Laboratory

Polymeric Matertals Laboratoory

Structural Dynamies Laboratory

Materials Properties \& Nondestructive

Evaluation Lab

Impact Dynarrics Support Building

Aircraft Crashworthiness Preparation Facitity

Impect Dynamics Support Facility

Aircraft Guidance \& Control Laboratory

Flight Electronjes/Etectromagnetics Laboratory 


\section{Lewis Research Center}

Engine Research Building

Commistry Loboratory

Icing Research Tronel

Special Projects Labotabry

Matcrials Research Laboratory

Matetials \& Structures Laboralory

Central Air Equipmeat Building

Instrument Research Laboratory

Engine Research Building Combustion Air Heater

Engine Components Research Laboratory

Materiais Processing Lahoratomy

Basic Materials Laboratoxy

PSL Heater Building

Eleciric Power Laboratory

Energy Conversion Laboratory

Space Power Research I aboratory

$8 \times 6$ Ft Supersonic Wind Tumnel

$10 \times 10 \mathrm{Ft}$ Supersonic Wind Tunnel

Plam Brook Sration

Entire Facility

Goddard Space Fligh Center

Research Projects Laboratory

Fight Control Range Operations

Instrument Derelopment Laboratory

Paylond Testing Facility
Environmentul Testing Laboratocy

Network Control Center

Spacectaft Operations Facility

Hitgh Canacity Centrifuge Facility

Space \& Terestrial Applications Facility

Data Interpretation Labonatory

Techtrical Processing Facility

Spaceeraft Systems Development/Integration

Quality AssuramcerDetector Development Lab.

Optical Test Site

Spacecraft Magnetic Test Sìte

Wallops Ftight Facility

Radar Facility

Machime \$hop - Fabrication

Aircraft Projects/Hangar Area

Electronics Support/Storgge

Mainland/sland

Jet Propulision Laboratory

Enviroumental Laboratory

25 Foox Space Simulator

Spacecraft Assembly Facility

Space Flight Operations Facillity

10 Foot Space Sianulator

Space Flight Support

Frequency Standards Laboratory

Earth \& Space Sclences Laboratory

Micro Devices Laboratory

\section{Panama Canal Commission}

Marrine Buresar (159 buikditugs)

Lock chanbers

Electrical toping koconotives

Canal navigational lighting

Computerized marine taffic entrol

Repair facilities

Relaled intrastructuras

Engineering \& Consinuction Buragu (257 buildings)

Jndusirial sector
Tog, Jocomotive, and dredging-rejated equipment repair sbops

Potable water processing

Comurunication

Uutility services

General Services Burean (239 buildings)

Vehigle maintenance and repair shops

Fire stations

Sanikation and grownds management facilities

High endrgy+consuming axtivities 


\section{U.S. Intormation Agency}

Rekay Station, Greenville, North Caroling

Relay Station, Delano, California

Rekay Station, Dixon, Califordia (mective)

Relay Station, Bethany, Ohto

Relay Station, Munich, Gemany

Relay Station, Kavala, Grece

Rstay Station, Rbodes, Grece
Relay Station, Bangkok, Thailand

Relay Staico, Tangter, Moraceo

Relay Station, Colomba, Sti Lemka

Relay Station, Botswana

Relay Station, Belize

Relay Station, Ptilippines

\section{U.S. Department of Agriculture}

\section{Birrss}

2 Bus Stations

87 Chemical Storage Buildutgs

8 Enghtering Factlities

4 Filling Stations

5 Fire Stations

479 Greenhouses

76 Garages

98 Headuouses

137 Housing Buildings

2 Inciterrator Buildings

514 Labotatory Butidings
78 Office Builtings

85 OfficelLaboratory Buildings

Cbeapel

6 Restroom Buildings

215 Sheds

158 Shops

426 Storage Buildings

54 Trailens

Weather Station

2 Waste Treatment Buildings

494 Ober Building Typer

\section{U.S. Departinent of State}

Main State Complex

Blair House Complex
Beltsville Information Management Center International Cuancery Cepter

\section{National Archives and Records Administration}

National Archives Builoing, Washington DC, National Archives at College Park, MD Heabert Hoover Library, West Branch, IA Harry $S$ Truman Ltbrary, Independence, MO Dwight D. Eisenhower Library, Abilene, KS Lypdon B. Jahnson Library, Austin, TX
Gerald R. Ford Libsary, Asn Athor, MI Gerald R. Ford Museum, Grand Rapids, MI Jimmy Carter Library, Attanta, OA Romald Reagan Library, Simi Valley, CA John Fizzgerald Kemeedy Library, Boston, MA 


\section{APPENDIX $\mathrm{F}$ \\ DEPARTMENT OF ENERGY: EDUCATION, EXTENSION, AND INEORMATION SERVICES}

Energy Efiktency and Renewable Energy Clearinghouse (EREC)

Coutact: Mary Cotrigan, (202) 586-1708

Office of Public Affairs

Contact: F. Chester Gray, (202) 586-6827

Energy Analysis and Diagnostic Center (EADC) Program

Contact: Charles J, Glaser, (202) 586-1298

Energy-Related Inventions Program (ERIP)

Contact: Terry Leviason, (202) 586-1478

Gas Mileage Guide

Contact: Shelia Perez, (202) 586-6723

Irstitutional Conservation Program (ICP)

Contect: Robert K. Volk, Jr, (202) 586-8034

Natioual Energy Informaticn Center, Energy Irformation Administration (NEICIEIA)

Contact: Sendra Wilkens, (202) 586-1173

Office of Federal Energy Management Programs (FEMP)

Contact: Mark Ginsberg, (202) 586-5772

Office of Scientilic and Tecknical Information (OST)

Contacl: Brian Hitsoa, (615) 576-1222

Pre-Freshman Entichment Program (PREP)

Contact: John Ottmenh, (202) 586-1634

Technical Information Rrogram, National Reanawable Energy Laboratory (NRFl,

Conlact: Nancy Reece, (303) 275-3688

State Energy Conservation Program (SECP)

Contact: Enestine Gitson, (202) 586-8294

Technical Information and Communication Program

Contact: Marsha Quinn, (202) 586-2097

Weatherization Asssistance Program

Contact: Jim Gardoer, (202) 586-2204 


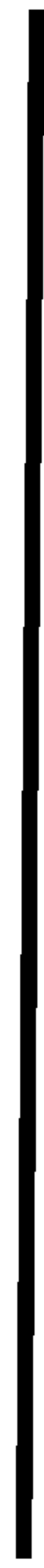




\section{APPENDIX G \\ FEDERAL INTERAGENCY ENERGY POLICY COMMITTEE \\ "656" COMMTTTLE}

"656" Committee Chair

The Honorable Christine Ervin

Assistant Secretary

Exergy Eficiency and Rentewable Energy

Task Force Execultive Director

Mr. Mark Ginsberg

Director, Ofitice of Federal Energy

Malagement Programs

U.S. Departiment of Energy, EE-90

Forrestal Building, Room SF-064

1000 Independeace Avenue, SW

Washington, DC 20585

Ptone: (202) 586-5772

Fax: (202) 586-3000

\section{Aericulture}

Mr. Wardell Townsend, Jr.

Assistant Secretary for Administration

U.S. Department of Agriculture

Adunitistration Bullding, Rocen 248W

14th and irdependence Aveaue, SW

Wastington, DC 20250

Phout: 202-720-3590

Fax: 202-720-2191

\section{Commerce}

Mr. Thomas R. Bloom

Chief Financial Oficer and

Assistant Secretary for Administration

U.S. Department of Commerce

Main Commerce, Room 5830

14th and Constitution Avenue, NW

Washington, DC 20230

Phone: 202-482-4951

Fax: 202-482-3592

\section{Defense}

Mir. Joshua Gotbanm

Assistant Secretary of Defense

for Economic Security

3300 Detense Pentagor

Washington, DC 20301-3300

Phone: 703-695.6639

Fax: 703-693-7011

\section{Education}

Mr. Rodney A. MoCowan

Assistant Secretary

Howan Resources and Administration

U.S. Department of EJucation

Second Floor

600 Independeace Aveone, SW

Washington, DC 20202

Phone: 202-401-0470

Fax: $202-401-0485$

Environmental Protection Apency

Mr. Jonathan Z Cannon

Asssistant Admiristrator and

Chief Financial Officer

Ofice of Administration and Resources Mamagement

Envircomental Protection Agency

Room 1111 West Tower

$401 \mathrm{M}$ Strett, SW

Washington, DC 20460

Phone: 202-260-4600

Fax: 202-260-0835

General Stervices Administration

Mr. Kenneth R. Kimbnough

Commissioner of Public

Buildings Service

General Services Administration

Room 6344

18th and F Streets, NW

Washington, DC 20405

Phone: 202-501- 1100

Fax: 202-219-2310

Health and Human Services

Ms. Elizabeth James

Acting Assistant Secretary

for Management and Budget

U.S. Department of Heallh

and Human Services

Hubert H. Humplarey Building

Room 508-G

200 Independence Avenue, $S w$

Waskinglon, DC 20201

Phore: 202-690-6061

Fax: $202-690-2405$ 
Housing and Urhan_Destelopment

Mss. Marilynn A. Davis

Assistant Secretary for Administration

U.S. Department of Housing and

Uthan Development, Room 10110

451 7th Street, SW

Washington, DC 20410

Fone: 202-708-0940

Fax: $202-619-8129$

Interior

Ms. Bommie R, Cohen

Assistant Secretary for Policy,

Managemeat and Budget

U.S. Department of the Interior

Mail Stop 6214, Roon 6117

$1849 \mathrm{C}$ Street, NW

Washington, DC 20240

Phone: 202-208-6182

Fax: 202-208-5048.

Justice

Mr. Stephen R. Colgate

Assistant Attonney General

for Administratiou

U.S. Departmert of Justice

Roon 1111

10th and Constitution Avenue, NW

Washington, DC 20530

Phone: 202-514-3101

Fax: 202-514-1778

Lahor

Ms. Cyotbla A. Metzler

Assistant Secretary

for Administration and Managernenk

U.S. Department of Labor

Room S-2514

200 Constitation Avenue, NW

Washington, DC 20210

Phone: 202-219-9086

Fax: 202-219-1270

National Aeromantics and

Space Adupiristration

Ms. Berlita A. Cooper

Associake Administrator for Management.

Systems and Facilities

National Aeronautics and

Space Administration

Code J, Room 3729

300 E Street, SW

Washington, DC 20546-0001

Fhone: 202-358-2800

Fax: 202-358-3068
Postal Service

Mr. Willtam Dowling

Vice Prestdent Engineering

U.S. Postal Service

8403 Loe Higtway

4th Floor

Morrifield, VA 22082-8101

Phone: 703-280-7001

Fax: $709-280-5669$

State

Mr. Patrick S. Kennedy

Assistant Sectetary

for Admioistration

U.S. Department of State

Room 6330

22tod \& C Streets, NW

Washington, DC 20520

Phone: 202-647-1492

Fax: $202-647-1558$

Trmisportution

Ms. Melissa Spillenkothen

Assistant Sectetary for Administration

U.S. Department of Transportation

Room $103 i 4$

400 7th Strot, Sw

Washingtoo, DC 20590

Puot 202-366-2332

Fax: 202-366-9634

Treasury

Mr. George Munoz

Assistant Secretary

for Management/Chief Financial Officer

U.S. Department of the Treasury

Room 2423, Main Treasury Building

15th \& Pennsylvania Avenue, $\mathrm{NW}$

Washington, DC 20220

Phone: 202-622-1280

Fax: 202-622-2795

Veterans Affeirs

Di. Thomas L. Garthwaite

Deputy Under Secretary for Health (10A)

U.S. Department of Veterans Affairs

Room 806

$\$ 10$ Vemont Avenue, NW

Washington, DC 20420

Phone: 202-273-5803

Fax: 202-273-7090 


\section{APPENDIX H \\ PERSONNEL OF THE DEPARTMENT OF ENERGY'S \\ FEDERAL ENERGY MANAGEMENT PROGRAM}

\section{FY 1994 Personutel}

Christine Ervin

Assistant Secretary, Energy Efficiency and Renewable Energy and Chair, Federal Interagency

Energy Policy Committee

Office of Federal Energy Management Programs Staff:

Marik Ginsberg, Director

Executive Secretary, Federal Interagency Energy Policy Committee, Executive Director, Interagency Energy Management Task Force

John Archibald

Veronica Bellamy

Ted Collins

Mark Decot

K. Dean DeVine, P.E.

Judy Florance

Louis Harris

Rick Klimkos

Bob McLaren

Deborah Miller

Pat O'Brien

Tanya Sadler

Anne Sprunt Crawley

Tatiana Strainic Muessel

Joan Stone

Nellie Tíbbs

Deborah Rose 
